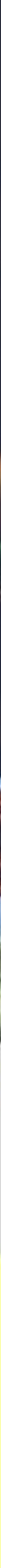

\title{
Ciência e Tecnologia
}

dos Alimentos 
Editora Poisson

\section{Ciência e Tecnologia dos Alimentos Volume 4}

1ạ Edição

Belo Horizonte

Poisson

2019 
Editor Chefe: Dr. Darly Fernando Andrade

\section{Conselho Editorial}

Dr. Antônio Artur de Souza - Universidade Federal de Minas Gerais Msc. Davilson Eduardo Andrade

Dra. Elizângela de Jesus Oliveira - Universidade Federal do Amazonas

Msc. Fabiane dos Santos

Dr. José Eduardo Ferreira Lopes - Universidade Federal de Uberlândia

Dr. Otaviano Francisco Neves - Pontifícia Universidade Católica de Minas Gerais

Dr. Luiz Cláudio de Lima - Universidade FUMEC

Dr. Nelson Ferreira Filho - Faculdades Kennedy

Msc. Valdiney Alves de Oliveira - Universidade Federal de Uberlândia

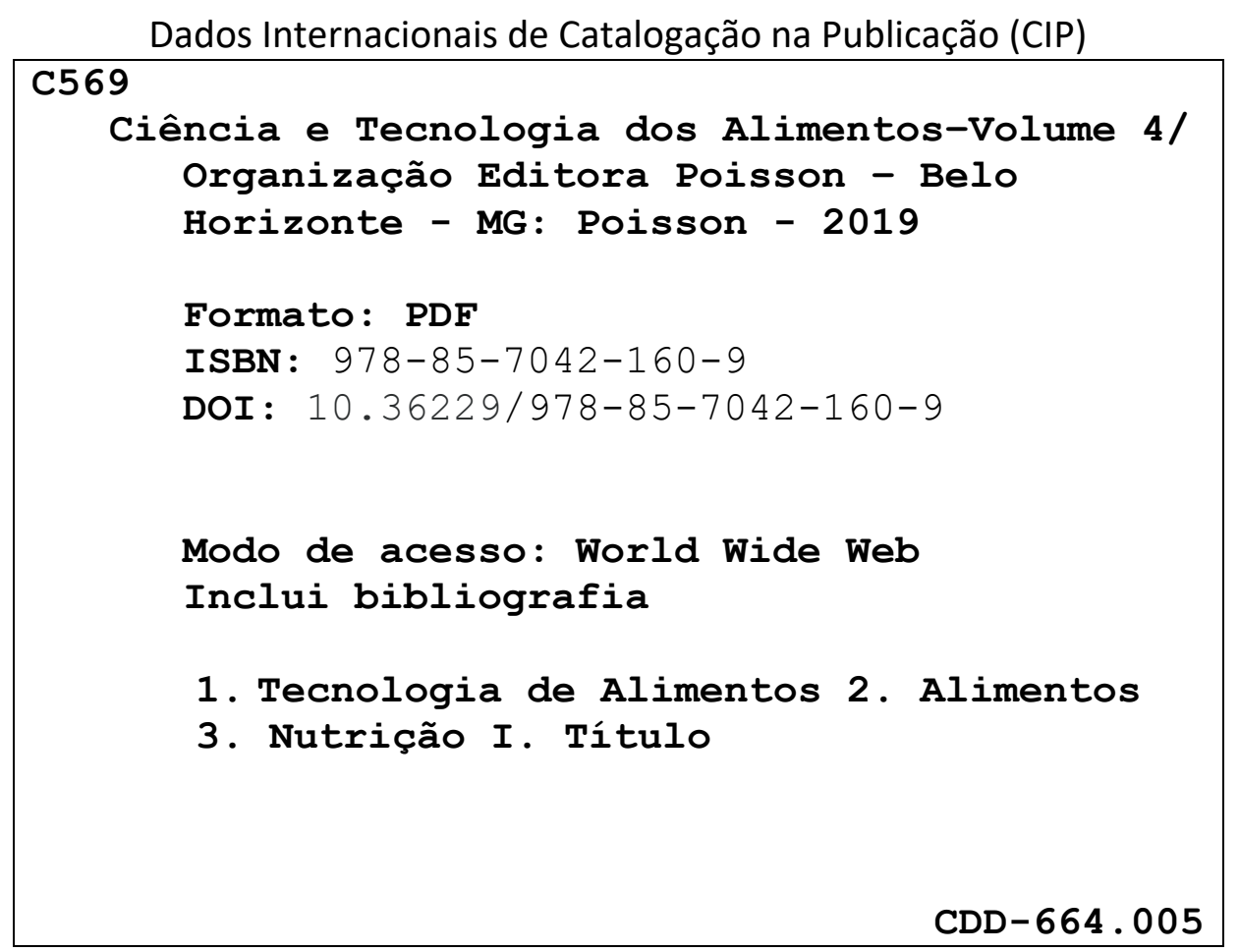

O conteúdo dos artigos e seus dados em sua forma correção e confiabilidade são de responsabilidade exclusiva dos seus respectivos autores.

$\underline{\text { www.poisson.com.br }}$

contato@poisson.com.br 


\section{SUMÁRIO}

Capítulo 1: Características físico-químicas, microscópicas e microbiológicas de polpa e xarope de mangaba

Simone Curvo Bett, Nágela Farias Magave Picanço, Rozilaine Aparecida Pelegrine Gomes de Faria, Cristiane Lopes Pinto Ferreira

DOI: $10.36229 / 978-85-7042-160-9 . C A P .01$

Capítulo 2: Estudo das características Físico-Químicas do melado comercializado no Seridó do RN 16

Arivonaldo Bezerra da Silva, Isandra de França Medeiros, Ramon Araujo dos Santos, Daulton Ruan Rufino de Souza, Leonardo de Almeida Marciano

DOI: 10.36229/978-85-7042-160-9.CAP.02

Capítulo 3: Elaboração e perfil físico-químico e microbiológico de farinha de cabeça de Tilápia do Nilo (Oreochromis Niloticus) 19

Denise Pastore de Lima, Katiane Aparecida Willy, Daiane Aparecida dos Santos

DOI: $10.36229 / 978-85-7042-160-9 . C A P .03$

Capítulo 4: Qualidade físico-química e microbiológica de marcas comerciais de mel de engenho comercializadas em João Pessoa-PB, Brasil 23

Roberto Kelwin Lopes da Costa e Lopes, Edilma Pinto Coutinho, Anderson Ferreira Vilela, Marcelo Barbosa Muniz, Kerolayne Santos Leite, José Honório Pereira Lopes Neto , Amanda da Silva Gomes, Helenice Duarte de Holanda

DOI: $10.36229 / 978-85-7042-160-9 . C A P .04$

Capítulo 5: Caracterização do maná-cubiu (Solanum sessiliflorum Dunal) produzido na Mata Atlântica do Estado do Paraná. 27

Aiane Benevide Sereno, Marlene Bampi, Luciana Gibbert, Francis José Zortea Merino, Renata Labrocini Bertin, Claudia Carneiro Hecke Krüger

DOI: 10.36229/978-85-7042-160-9.CAP.05

Capítulo 6: Compostos bioativos presentes em abricó (Mammea americana), fruta da região amazônica brasileira 33

Pollyane da Silva Port's, Wellington da Silva Oliveira, José Teixeira Filho, Helena Teixeira Godoy

DOI: $10.36229 / 978-85-7042-160-9 . C A P .06$

Capítulo 7: Filmes de amido/quitosana adicionados de fibras, nanofibras e fibras mercerizadas obtidas da palha de trigo

Renata Paula Herrera Brandelero, Evandro Martin Brandelero, Guilherme Landim Santos

DOI: $10.36229 / 978-85-7042-160-9 . C A P .07$ 


\section{SUMÁRIO}

Capítulo 8: Extração e caracterização da composição lipídica da borra de café robusta e arábica 51

Cleber Luiz de Moura, Isabel Craveiro Moreira Andrei, Lisandra Ferreira de Lima, Lyssa Setsuko Sakanaka DOI: 10.36229/978-85-7042-160-9.CAP.08

Capítulo 9: Viabilidade de Lactobacillus acidophilus Microencapsulado com pectina armazenado em temperatura de refrigeração 56

Lucas Nachtigal, Maria Fernanda da Silveira Cáceres de Menezes, Cassandra de Deus, Bruna de Souza da Fonseca, Cristiano Ragagnin de Menezes

DOI: 10.36229/978-85-7042-160-9.CAP.09

Capítulo 10: Transesterificação de óleo residual de fritura de couro suíno desidratado 62

Artur Faria Gonçalves, Osmar Caôn Filho, Tiago Sartorelli Prato

DOI: $10.36229 / 978-85-7042-160-9 . C A P .10$

Capítulo 11: Kefir Vinegar: Assessment of metabolic activity of Kefir by Biospeckle Laser

Karina Teixeira Magalhães-Guedes, Roberta Oliveira Viana, Roberto Alves Braga Jr, Disney Ribeiro Dias, Rosane Freitas Schwan, Itaciara Larroza Nunes

DOI: 10.36229/978-85-7042-160-9.CAP.11

Capítulo 12: Produção de banana-passa obtida por processos combinados de desidratação osmótica e secagem convectiva.................................................................76 Pablícia Oliveira Galdino, Bruno Henrique da Silva Melo, Júlia Mendes de Lima, Ângela Maria Santiago, Plúvia Oliveira Galdino,

DOI: $10.36229 / 978-85-7042-160-9 . C A P .12$

Capítulo 13: Presença de resíduos de medicamentos veterinários, contaminantes inorgânicos e dioxina em aves e ovos.

Amanda Teixeira Bittencourt, Márcia Keller Alves

DOI: $10.36229 / 978-85-7042-160-9 . C A P .13$

Capítulo 14: Aceitação e avaliação sensorial de queijos caprinos pelo método CATA (Check-All-That-Apply)

Selene Daiha Benevides, Deborah dos Santos Garruti, Idila Maria da Silva Araújo, Carlos Ruan Vieira de Sousa, Luis Eduardo Laguna, Antônio Silvio do Egito

DOI: $10.36229 / 978-85-7042-160-9 . C A P .14$ 


\section{SUMÁRIO}

Capítulo 15: Fabricação de queijo minas frescal zero lactose 92

Lívia Borges de Sousa, Karla Vitória Alves Sampaio, Milena Silva Correia, Renata Cunha dos Reis, Ulisses Rodrigues de Alencar, Diva Mendonça Garcia

DOI: $10.36229 / 978-85-7042-160-9 . C A P .15$

Capítulo 16: Percepção dos consumidores sobre a qualidade dos produtos lácteos. 102 Adriana Soraya Araújo, Dáffyne Kelly Silva Costa Oliveira, Ilana Morgana Ferreira Araújo dos Santos, Maria de Fátima de Sousa Cascaes

DOI: $10.36229 / 978-85-7042-160-9 . C A P .16$

Capítulo 17: Sorvetes prebióticos de leite de ovelha desnatado: Aspectos tecnológicos, funcionais e nutricionais 108

Celso Fasura Balthazar, Hugo L. A. Silva, Alexandre Hargreaves Vieira, Wanessa Pires da Silva, Erick de Almeida Esmerino, Mônica Queiroz de Freitas, Adriano Gomes da Cruz,

DOI: $10.36229 / 978-85-7042-160-9 . C A P .17$

Capítulo 18: Readequação do processo produtivo e da distribuição de salgados quentes em lanchonete de uma rede de supermercados da Grande Florianópolis/SC........ 121

Lucas Vaz da Rosa, Laura Gabriela Magnabosco, Roberta Juliano Ramos, Isaura Hammerschmitt Clemente DOI: $10.36229 / 978-85-7042-160-9 . C A P .18$

Capítulo 19: Análise comparativa de preços entre hortifrutícolas orgânicas e convencionais na alimentação escolar

Bárbara Dorneles Pontes, Susana Berleze de Pelegrini, Carla Cristina Bauermann Brasil, Tiffany Prokopp Hautrive

DOI: $10.36229 / 978-85-7042-160-9 . C A P .19$

Capítulo 20: Avaliação das condições higiênico-sanitárias em um estoque de armazenamento de alimentos de uma escola do Município de Seropédica/RJ

Maria Rosa Figueiredo Nascimento, Yzadora Maura de Figueiredo, Ronel Joel Bazán Colque

DOI: $10.36229 / 978-85-7042-160-9 . C A P .20$

Capítulo 21: Nível de segurança de fórmulas infantis preparadas no Lactário de um hospital universitário do Estado do Rio de Janeiro 141

Deborah Rodrigues Siqueira, Silvia Magalhães Couto Garcia, Maria Lúcia Mendes Lopes, Carolina Pinto de Carvalho Martins, Carolina Cataldo

DOI: $10.36229 / 978-85-7042-160-9 . C A P .21$ 


\section{SUMÁRIO}

Capítulo 22: Avaliação do conhecimento e atuação de manipuladores de alimentos em redes de escolas estaduais do Município de Três Passos/RS 146

Luciana de Abreu, Fernanda Hart Weber, Mastrangello Enivar Lanzanova, Glaciela Cristina Rodrigues da Silva Scherer, Hardi Germano Weirich

DOI: $10.36229 / 978-85-7042-160-9 . C A P .22$

Autores: 


\section{Capítulo 1}

Características físico-químicas, microscópicas e microbiológicas de polpa e xarope de mangaba

\section{Simone Curvo Bett}

Nágela Farias Magave Picanço

Rozilaine Aparecida Pelegrine Gomes de Faria

\section{Cristiane Lopes Pinto Ferreira}

Resumo: 0 objetivo do trabalho foi avaliar as características físico-químicas, microbiológicas e microscópicas de polpa de mangaba congelada antes e após pasteurização e do xarope produzido com a polpa de mangaba. A polpa foi fornecida por estabelecimento comercial de gelados comestíveis da cidade de Goiânia - GO. Foram realizadas análises de pH, acidez titulável em ácido cítrico, sólidos solúveis e Ratio (relação sólidos solúveis e acidez titulável em ácido cítrico), pesquisa de coliformes totais e termotolerantes, bolores e leveduras, bactérias mesófilas e Salmonella spp, quanto à microscopia foi pesquisado presença de matérias macroscópicas e microscópicas prejudiciais à saúde humana. Os resultados físico-químicos, microbiológicos e microscópicos apresentaram-se de acordo com os padrões de identidade e qualidade estabelecidos pelas legislações vigentes. Conclui-se que as polpas e o xarope de mangaba apresentaram qualidade satisfatória para consumo humano.

Palavras-Chave: polpa congelada, fruto do cerrado, Hancornia speciosa 


\section{INTRODUÇÃO}

O Brasil foi o terceiro maior produtor mundial de frutas com 42,6 milhões de toneladas de frutas em 2,2 milhões de hectares de área plantada em 2008 (IBRAF, 2010). As frutas nativas estão cada vez mais inseridas neste mercado, atendendo a novos padrões de consumo, associados principalmente ao seu lugar de produção e à possibilidade de consumir algo de aparência e sabor diferente (MOTA et al., 2008).

No contexto agroindustrial existe um vasto potencial para a exploração de frutas nativas e exóticas que constituem fontes alternativas de nutrientes e compostos bioativos com potencial antioxidante, contudo a agregação de valor na forma de produtos processados ainda é um desafio para o desenvolvimento regional. Torna-se relevante acrescentar que a implantação de agroindústrias, além de agregar valor às frutas, proporciona o aproveitamento dos excedentes de safra, cria empregos permanentes e interioriza o desenvolvimento (MORAIS et al., 2013; CORDEIRO et al., 2013). 0 processamento de frutas em doces, compotas, geleias, frutas cristalizadas, sucos, sucos concentrados, sorvetes, licores agrega valor aos produtos a ser comercializados tornando as espécies frutíferas uma alternativa de complementação de renda para as comunidades locais (MATA, 2007).

Incentivar a utilização de produtos regionais na alimentação, neste caso a mangaba, tem como consequência mudanças no sistema de produção local, aumento de interesse pelo cultivo, incentivando a extração racional com produção e transformação do produto final com geração de renda, além de valorizar e resgatar a cultura alimentar e tornar a mangaba visível no mercado (BRASIL, 2005).

A mangaba é fruto da árvore mangabeira (Hancornia speciosa), nativa do Brasil e apresenta grande importância social, econômica e cultural. Está presente naturalmente nas regiões do Nordeste e CentroOeste do Brasil, fazendo parte da flora da Caatinga, do Cerrado e dos Tabuleiros Costeiros. Pode ser encontrado também no litoral e em algumas regiões do Pará, Vale do Rio Tapajós e Região Amazônica, o maior produtor é o estado de Sergipe (SOARES JUNIOR et al., 2008; LIMA, 2010; COSTA et al., 2011). 0 fruto é consumido completamente maduro, ou seja, quando este se desprende facilmente da árvore, que normalmente atinge de quatro a cinco metros de altura (ROSA et al., 2005).

Os frutos da mangabeira são aromáticos, saborosos e nutritivos, com elevada aceitação no mercado. 0 seu consumo pode ser in natura ou processado, como polpas, geleias, sorvetes, sucos, doces, bolos, biscoitos e licores (LIMA, 2010). Devido à sua propriedade de agregação e retenção de sabor, é muito utilizada na elaboração de sorvetes (SOARES et al., 2006).

A mangaba apresenta altos valores de sólidos solúveis totais e elevada acidez, o que resulta em um paladar exótico e sabor "sui generis" muito apreciado pelos seus consumidores (OETTERER et al., 2006).

A qualidade da polpa está relacionada à preservação dos nutrientes e às suas características microbiológicas, físico-químicas e sensoriais, que devem ser próximas da fruta in natura, de forma a atender as exigências do consumidor e da legislação vigente (DANTAS et al., 2012).

A Instrução Normativa No 01/2000, do Ministério da Agricultura do Abastecimento do Brasil fixa os padrões de identidade e qualidade para polpa de fruta, em seu anexo XVI - Regulamento Técnico para Fixação de Identidade e Qualidade para Polpa de Mangaba define como polpa de fruta todo produto não fermentado, não concentrado, não diluído, obtido de frutos polpudos, através de processo tecnológico adequado, com um teor mínimo de sólidos totais, proveniente da parte comestível do fruto (BRASIL, 2000).

Segundo Instrução Normativa № 18, de 19 de junho de 2013, que estabelece a complementação dos padrões de identidade e qualidade para algumas bebidas, define Xarope como produto não gaseificado, obtido pela dissolução, em água potável, de suco de fruta, polpa ou parte do vegetal e açúcar, numa concentração mínima de 52\% de açúcares, em peso, a 20oC (BRASIL, 2013).

Assim, o objetivo deste trabalho foi avaliar a qualidade físico-química, microbiológica e microscópica da polpa congelada de mangaba antes e após a pasteurização e do xarope de mangaba produzido com polpa de mangaba. 


\section{MATERIAL E MÉTODOS}

O experimento foi realizado em Delineamento Inteiramente Casualizado, com 3 unidades amostral, todas em triplicata.

A polpa de mangaba congelada foi fornecida por estabelecimento comercial do ramo de gelados comestíveis, situada na cidade de Goiânia, Estado de Goiás. A amostra foi transportada congelada em caixa isotérmica com gelo seco, lacrada e identificada. Foi mantida a $-18^{\circ} \mathrm{C}$, até o momento das análises e processamento.

Foi retirada do volume total 3 porções de $500 \mathrm{~g}$ para as análises. Foram totalmente descongeladas e homogeneizadas para os testes de avaliação da qualidade higiênico-sanitária.

A pasteurização da polpa e o preparo do xarope de mangaba foram realizados no Laboratório de Bromatologia do Instituto Federal de Mato Grosso, Campus Bela Vista, na cidade de Cuiabá - MT.

A polpa congelada foi pasteurizada a 750C por 30 minutos (MORAES, 2006), em seguida foram pesadas e embaladas em potes de polietileno com capacidade de 100 e $200 \mathrm{~g}$, congeladas e armazenadas até o momento das análises.

0 xarope de mangaba foi preparado com 35\% de polpa in natura, $54 \%$ de sacarose e $11 \%$ de água. Em seguida a mistura foi aquecida até completa homogeneização.

\subsection{DETERMINAÇõES FÍSICO-QUÍMICAS}

Foram realizadas no Laboratório de Bromatologia do Instituto Federal de Mato Grosso, campus Cuiabá Bela Vista. Avaliaram-se os teores de acidez titulável em ácido cítrico por titulometria, oBrix utilizando refratômetro do tipo ABBE marca Biobrix, modelo 2WAJ e a relação de sólidos solúveis e acidez titulável (Ratio) segundo métodos indicados pelo Instituto Adolfo Lutz (2005), pH pelo método da Association of Official Analytical Chemits (1995) medido em potenciômetro digital marca Marte modelo MB-10, calibrado com soluções tampões de pH 4,0 e 7,0 a 25 oC.

\subsection{DETERMINAÇõES MICROBIOLÓGICAS}

Foram realizadas na Gerência de Análises de Vigilância Ambiental e Sanitária do MT - Laboratório / SES MT. Pesquisou-se presença de Salmonella spp (FDA/BAM, 2007). Coliformes totais e coliformes termotolerantes (APHA, 2001a), contagem de bactérias aeróbias mesófilas (APHA, 2001b) e contagem de bolores e leveduras (APHA, 2001c).

\subsection{DETERMINAÇÕES MICROSCÓPICAS}

Foram realizadas na Gerência de Análises de Vigilância Ambiental e Sanitária do MT - Laboratório / SES MT. Foi pesquisada presença matérias macroscópicas e microscópicas prejudiciais à saúde humana, pelo método de filtração segundo metodologia do Instituto Adolfo Lutz (2005), com o uso de aparelho estereoscópio da marca Leica, modelo S6E para matérias macroscópicas e microscópio óptico marca Olympus modelo BH-2 para matérias microscópicas.

\subsection{ANÁLISE ESTATÍSTICA}

Os resultados das análises físico-químicas foram submetidos à análise de variância (ANOVA) e o teste de Tukey para comparação de médias, foi considerado nível de significância $p \leq 0,05$. Foi utilizado o Programa Assistat versão 7.6 Beta (atualizada em 06.06.2013) (SILVA, 2013).

Os resultados das análises microbiológicas foram expressos em valores médios com desvio padrão. Os resultados das análises microscópicas foram descritivos. 


\section{RESULTADOS E DISCUSSÃO}

\subsection{CARACTERÍSTICAS FÍSICO-QUÍMICAS}

Houve diferença significativa entre os valores de $\mathrm{pH}$ e acidez em ácido cítrico para polpa in natura, pasteurizada e xarope de mangaba (Tabela 1). 0 maior valor de $\mathrm{pH}$ foi para polpa pasteurizada $(3,9)$. 0 contrário foi observado para acidez em ácido cítrico em que o maior valor foi apresentado pela polpa in natura (1,07 g ácido cítrico. $100 \mathrm{~g}-1$ amostra).

Tabela 1. Características físico-químicas da polpa de mangaba congelada pré e pós-pasteurização e xarope de mangaba.

\begin{tabular}{|c|c|c|c|c|}
\hline & $\mathrm{pH}$ & $\begin{array}{c}\text { Acidez (g ácido } \\
\text { cítrico } / 100 \mathrm{~g})\end{array}$ & oBrix (\%) & Ratio \\
\hline Polpa in natura & $3,56 \mathrm{c}$ & $1,07 \mathrm{a}$ & $14,06 \mathrm{~b}$ & $12,84 \mathrm{a}$ \\
\hline Polpa pasteurizada & $3,73 \mathrm{~b}$ & $0,99 \mathrm{~b}$ & $14,83 \mathrm{~b}$ & $14,91 \mathrm{a}$ \\
\hline Xarope de mangaba & $3,9 \mathrm{a}$ & $0,40 \mathrm{c}$ & $53,83 \mathrm{a}$ & $-\cdots$ \\
\hline
\end{tabular}

Médias seguidas pela mesma letra na mesma coluna não diferem estatisticamente entre si. Foi aplicado teste de Tukey ao nível de $5 \%$ de probabilidade.

Conforme Instrução Normativa 01 de 2000 em seu anexo XVI que regulamenta os padrões de identidade e qualidade da polpa de mangaba (BRASIL, 2000), o valor de pH mínimo deve ser de 2,8 enquanto que ácido cítrico deve ser de 0,70 g.100 g-1 amostra, estando em conformidade com o padrão de identidade e qualidade exigido pela legislação.

A polpa antes da pasteurização apresentou maior acidez (1,07 g de ácido cítrico em $100 \mathrm{~g}$ de polpa), enquanto o xarope apresentou menos acidez em comparação com as polpas $(0,4 \mathrm{~g}$ de ácido cítrico).

Os valores apresentados de $\mathrm{pH}$ e acidez titulável em ácido cítrico foram acima dos relatados para frutos oriundos de João Pessoa - PB (pH: 2,99 e acidez: 1,77\%) por Souza et al. (2007), Campos et al. (2011) pesquisando métodos de conservação da mangaba obteve valores de acidez titulável (0,55 g ácido cítrico.100 g-1 nos frutos recém colhidos alterando paara 0,76 g dependendo do método de conservação) menores quando comparado aos resultados desta pesquisa. É possível que essa diferença de pH e acidez titulável em ácido cítrico deva-se ao local de produção da mangaba, época de colheita e das condições climáticas, pois Ferreira et al. (2013) e Silva et al. (2013) encontraram variabilidade quanto às características físico-química e ecofisiológicas entre mangabeiras de diferentes localidades.

A acidez total titulável elevada diminui a necessidade de adição de acidificantes e contribui para melhora nutricional, segurança alimentar e qualidade organoléptica (ROCHA et al., 2001). A determinação de pH, acidez titulável e sólidos solúveis totais permite verificar alterações ocorridas durante o processamento e armazenamento da polpa de fruta (PAGLARINI et al., 2011).

$\mathrm{O}$ aumento no $\mathrm{pH}$ com redução na acidez em ácido cítrico sugere perdas na vitamina C durante o processamento térmico, tanto na pasteurização quanto no preparo do xarope, pois Silva Junior (2004a) e Assunpção et al. (2013), relatam que a mangaba é uma boa fonte de vitamina C, em torno de 200 a 300 mg.100g-1. A vitamina $C$ é um potente agente redutor que se oxida facilmente, sendo também uma das vitaminas mais sensíveis ao processamento e as condições de armazenamento (SUCUPIRA et al., 2012). Durante o processo de pasteurização pode ocorrer perdas expressivas no teor de vitamina $\mathrm{C}$, o que é esperado devido à elevada instabilidade desta vitamina quando submetida à alta temperatura (CORREIA et al., 2008).

Os resultado de acidez titulável e pH apresentado pelo xarope está de acordo com as recomendações de Silva Junior (2004b), que para melhor conservação do alimento processado é necessário acidez elevada com pH menor que 4,2 .

Não houve diferença significativa de sólidos solúveis (oBrix) e Ratio (relação sólidos totais /acidez titulável) entre as polpas in natura e pasteurizada. Porém os valores encontrados estão $65 \%$ maiores que os exigidos pela legislação (BRASIL, 2000). Houve diferença significativa entre as polpas e o xarope. Souza et al. (2007) e Carvalho et al. (2009) encontraram valores de oBrix maiores aos observados, sugere-se que o grau de amadurecimento e genótipos diferentes de mangaba possam ser responsáveis por essas 
diferenças (CARNELOSSI et al., 2009; NARAIN et al., 2005). 0 oBrix do xarope ficou muito acima dos valores da polpa, com diferença significativa, isso devido à adição do açúcar para produção do xarope, elevando o número de sólidos solúveis totais dissolvidos.

Os sólidos solúveis caracterizam principalmente os açúcares, variando com a espécie, o cultivar, o grau de maturação e o clima (CHITARRA e CHITARRA, 2005), indicam a quantidade de substancias dissolvidas na polpa do fruto e com isso indicam o índice de maturação para alguns frutos (GONGATTI NETO et al., 1996).

A relação Sólidos Solúveis Totais/Acidez Titulável, ou "Ratio", não apresentaram diferença significativa entre as polpas, com valores de 12,84 e 14,91 para as polpas não pasteurizadas e pasteurizadas, respectivamente, esses valores foram superiores ao encontrado por Souza et al. (2007). Narain et al. (2005), observaram o mesmo comportamento em sua pesquisa na relação oBrix/acidez (Ratio) elevada. Essa relação indica o grau de amadurecimento do fruto no momento do processamento da polpa (NARAIN et al., 2005).

\subsection{CARACTERÍSTICAS MICROBIOLÓGICAS}

Quanto à qualidade microbiológica, a polpa congelada de mangaba não apresentou crescimento do grupo Coliforme e Salmonella spp antes da pasteurização, qualidade mantida após o tratamento térmico e/ou preparo do xarope. Os resultados encontram-se dentro dos padrões estabelecidos pela ANVISA (2001), na RDC No12 de 02 de janeiro de 2001, que estabelece para as polpas de frutas concentradas ou não, com ou sem tratamento térmico, refrigeradas ou congeladas devem apresentar limite máximo de Coliformes termotolerantes de 102 NMP.g-1 (Número Mais Provável por grama) e ausência de Salmonella spp em 25 g de polpa.

Conforme a Tabela 2, a polpa analisada antes da pasteurização apresentou contagem de Bolores e Leveduras de 2,20 x 103 UFC.g-1 de polpa, valor abaixo do que estabelece a instrução normativa, (BRASIL, 2000), com limite máximo de 5 x 103 UFC.g-1 de fungos e leveduras. Após a pasteurização não houve crescimento desses microrganismos nas diluições realizadas.

Tabela 2. Características microbiológicas da polpa de mangaba congelada pré e pós-processamento térmico.

\begin{tabular}{|c|c|c|c|c|}
\hline & $\begin{array}{c}\text { Coliformes } \\
\text { termotolerantes } \\
(\mathrm{NMP} / \mathrm{g})\end{array}$ & $\begin{array}{c}\text { Bolores e } \\
\text { leveduras (UFC/g) }\end{array}$ & $\begin{array}{c}\text { Bactérias } \\
\text { mesófilas } \\
(\mathrm{UFC} / \mathrm{g})\end{array}$ & $\begin{array}{c}\text { Salmonella spp } \\
(25 \mathrm{~g})\end{array}$ \\
\hline Polpa in natura & $<3,6$ & $2,2 \times 103$ & $3,83 \times 10$ & Ausência \\
\hline Polpa pasteurizada & $<3,6$ & $<10$ & $<10$ & Ausência \\
\hline Xarope de mangaba & $<3,6$ & $<10$ & $<10$ & Ausência \\
\hline
\end{tabular}

Os fungos pertencem a um grupo importante de deterioradores, porém fazem parte da microbiota natural das frutas e podem se desenvolver em uma ampla faixa de atividade de água e de $\mathrm{pH}$, são poucos exigentes em nutrientes e apresentam baixa resistência a temperaturas superiores a 60 oC (FERRO, 2012).

A polpa antes do processo de pasteurização apresentou contagem de bactérias mesófilas de 3,83 x 10 UFC. g-1. Após a pasteurização e preparo do xarope de mangaba não houve crescimento em nível de detecção pelo método analítico.

Na conservação de alimentos congelados em temperaturas inferiores a -5 e -8 oC, ocorre paralisação ou redução da carga microbiana devido à morte ou injuria celular durante o processo de congelamento, podendo ocorrer danos mecânicos nas paredes celulares, devido à formação de cristais intracelulares, perda do balanço eletrolítico, ruptura das membranas e diminuição do volume celular (GEIGES, 1996). 


\subsection{CARACTERÍSTICAS MICROSCÓPICAS}

Não foi observada presença de matérias macroscópicas ou microscópicas prejudiciais à saúde humana, como sujidades, fragmento de insetos, larvas, parasitos ou partes não comestíveis da fruta ou da planta na polpa de mangaba congelada.

Resultado similar foi encontrado por Santos e Barros (2012), que não detectaram presença de sujidades ou elementos histológicos nas polpas de frutas de goiaba, acerola e maracujá da mesma marca comercializadas em Paragominas - PA. Porém Pereira et al. (2006) e Oliveira et al. (2012) observaram em suas pesquisas com polpa de frutas congeladas disponíveis no mercado, presença de sujidades, como fragmento de insetos, inseto/larva inteira, partes não comestíveis da fruta ou cor não característica do produto.

\section{CONCLUSÃO}

As polpas de mangaba antes e após o tratamento térmico e o xarope de mangaba apresentaram características físico-químicas, microbiológicas e microscópicas dentro do estabelecido pelas legislações.

Os resultados da polpa e xarope de mangaba mostraram satisfatórios para o consumo humano.

\section{AGRADECIMENTOS}

Agradecimento à Frutos do Brasil, IFMT - Bela Vista, IFMT - PROPES, CAPES e Lacen / MT-Laboratório pelo apoio.

\section{REFERÊNCIAS}

[1] AMERICAN PUBLIC HEALTH ASSOCIATION (APHA). Compendium of methods for the microbiological examination of foods Enterobacteriaceae, Coliforms and Escherichia coli as Quality and Safety indicators, $4^{\mathrm{a}}$ ed. APHA. 2001a, p. 69-82

[2] AMERICAN PUBLIC HEALTH ASSOCIATION (APHA). Compendium of methods for the microbiological examination of foods Aerobc Plate Count, 4⿳⺈ ed. APHA. 2001b, p. 63-67.

[3] AMERICAN PUBLIC HEALTH ASSOCIATION (APHA). Compendium of methods for the microbiological examination of foods Yeasts and Molds, 4⿳a ed. APHA. 2001b, p. 209-213.

[4] ANVISA - Agencia Nacional de Vigilância Sanitária. Resolução RDC № 12 de 02 de janeiro de 2001. Aprova regulamento técnico sobre rotulagem nutricional de alimentos embalados, tornando obrigatória a rotulagem nutricional.

[5] ASSUMPÇÃO, C. F.; BACHIEGA, P.; SANTANA, A. T. M. C.; MORZELLE, M. C.; VILAS BOAS, B. M.; SOUZA, E. C.M de. Nectar misto de mangaba (Hancornia speciosa Gomes) e cagaita (Eugenia dysenterica): perfil sensorial e características físico-químicas. Revista Brasileira de Produtos Agroindustriais, Campina Grande, v. 15, n. 3, p.m 219$224,2013$.

[6] BRASIL, Ministério da Agricultura, Pecuária e Abastecimento. Instrução Normativa № 01 de 07 de janeiro de 2000. Aprova o regulamento técnico geral para fixação dos padrões de identidade e qualidade para polpa de fruta.

[7] BRASIL. Ministério da Saúde. Secretaria de Atenção à Saúde. Coordenação-Geral da Política de Alimentação e Nutrição. Guia alimentar para a população brasileira: promovendo a alimentação saudável. 236p. 2005.

[8] BRASIL, Ministério da Agricultura, Pecuária e Abastecimento. Instrução Normativa № 18 de 19 de junho de 2013. Estabelece os padrões de identidade e qualidade para as seguintes bebidas: xarope, preparado líquido para refresco, preparado líquido para refrigerante, preparado líquido para bebida composta e preparado líquido para chá.

[9] CAMPOS, R. P.; KNOCH, B.; HIANE, P. A.; RAMOS, M. I. L.; RAMOS FILHO, M. M. 1-MCP em mangabas armazenadas em temperatura ambiente e a 110C. Revista Brasileira de Fruticultura. Jaboticabal, SP, volume especial, p. 206-212, 2011.

[10] CARNELOSSI, M. A. G.; SENA, H. C.; NARAIN, N.; YAGUIU, P.; SILVA, G. F. Physico-chemical quality changes in mangaba (Hancornia speciosa Gomes) fruit stored at different Temperatures. Brasilian Archives of Biology and Technology an International Journal, Curitiba, v. 52, n. 4, p. 985-990, 2009. Disponível em: http://www.scielo.br/pdf/babt/v52n4/v52n4a23.pdf. Acesso em: 17 dez. 2012. 
[11] CARVALHO, C. A. L.; DANTAS, A. C. V. L.; PEREIRA, F. A. C.; SOARES, A. C. F.; MELO FILHO, J. F.; OLIVEIRA, G. J. C. Tópicos em Ciências Agrárias, Cruz das Almas, v. 1, 2009, 270p. Disponível: <www.ufrb.edu.br/manejo/index.php?option>. Acesso em: 07 mar. 2013

[12] CHITARRA, I. F.; CHITARRA, A. B. Pós-colheita de frutas e hortaliças: fisiologia e manuseio. LAVRAS: UFLA, $785 \mathrm{p}, 2005$.

[13] CORDEIRO, M. W. S.; CAVALLIERI, A. L. F.; FERRI, P. H.; NAVES, M. M. V. Características físicas, composição químico-nutricional e dos óleos essenciais da polpa de Caryocar brasiliense nativo do estado de Mato Grosso. Revista Brasileira de Fruticultura, Jaboticabal, v. 35, n. 4, p. 1127-1139, 2013.

[14] CORREIA, L. F.M.; FARAONI, A.S.; PINHEIRO-SANT'ANA. H.M. Efeito do processamento industrial de alimentos sobre a estabilidade de vitaminas. Alimentação e Nutrição, Araraquara, v.19, n.1, p.83-95, jan./mar. 2008.

[15] COSTA, T. S.; SILVA, A. V. C.; LÉDO, A. S.; SANTOS, A. R. F.; SILVA JÚNIOR, J. F. Diversidade genética de acessos do banco de germoplasma de mangaba em Sergipe. Pesquisa agropecuária brasileira. Brasília, v.46, n.5, p.499-508, 2011.

[16] DANTAS, R.L.; ROCHA, A.P.T.; ARAUJO, A.S.; RODRIGUES, M.S.A.; MARANHAO, T.K.L. Qualidade microbiológica de polpas de frutas comercializadas na cidade de Campina Grande - PB. Revista Brasileira de Produtos Agroindustriais, Campina Grande, v. 14, n.2, p.125-130, 2012.

[17] FERREIRA, E.G.; ARAUJO, I.S.; ALVES, E.O.; COSTA, G.D.; SILVA, H.B. Caracterização molecular de mangabeira (hancornia speciosa) dos tabuleiros costeiros de Pernambuco e Rio Grande do Norte no Nordeste do Brasil. Revista Verde de Agroecologia e Desenvolvimento Sustentável. Mossoró - RN, v.8, n.1, p.7-10, 2013.

[18] FERRO, J. H. A. Conservação da polpa de mangaba (Hancornia speciosa Gomes) por métodos combinados. 2012. 116p. Dissertação (Mestrado em Agronomia). Universidade Federal de Alagoas. 2012.

[19] FOOD AND DRUG ADMINSTRATION, BACTERIOLOGICAL ANALYTICAL MANUAL ON LINE (FDA/BAM). Salmonella. Chapter 5, updated $\quad$ December 2007. Disponível em: <http://www.fda.gov/food/ScienceResearch/LaboratoryMethods/BacteriologicalAnalyticalManualBAM/default.htm $>$.

[20] FRANCO, B.D.G.M.; LANDGRAF, M. Microbiologia dos alimentos. 2Ed. São Paulo: Atheneu, 2003, 182p.

[21] GEIGES, O. Microbial processes in frozen foods. Advances in Space Research, London, v.18, n.12, p.109-118, 1996

[22] GONGATTI NETO, A.; ARDITO, E.F.G.; GARCIA, E.E.C.G.; BLEINROTH, E.W.; FREIRE, F.C.O.; MENEZES, J.B.; BORDINI, M.R.; SOBRINHO, R.B.; ALVES, R.E. Acerola para exportação: procedimentos de colheita e pós-colheita. MAARA/SDR - Brasília: EMBRAPA - SPI, 1996, 30p.

[23] IBRAF. INSTITUTO BRASILEIRO DE FRUTAS. 2010. Brasil é o terceiro maior produtor de frutas do mundo. Disponível em: <http://www.clicrbs.com.br/especial/rs/expointer-2010/19,0,2535814,Brasil-e-o-terceiro-maiorprodutor-de-frutas-do-mundo.html>. Acesso em: 08 out. 2013.

[24] INSTITUTO ADOLF LUTZ. Métodos físico-químicos para análise de alimentos. 4ª Ed., cap. 4 e 15, 2005, p. 83$160 ; 571-591$.

[25] LIMA, I. L. P. Boas práticas de manejo para o extrativismo sustentável da mangaba. Embrapa Recursos Genéticos e Biotecnologia, Brasília, 68p, 2010.

[26] MATA, M. E. R. C. Potencial de suo industrial das matérias primas do semiárido. Brasília: Centro de Gestão e Estudos Estratégicos. Nota Técnica, p. 53, 2007.

[27] MORAES, I.V.M. Dossiê Técnico - produção de polpa de fruta congelada e suco de frutas. Rede de Tecnologia do Rio de Janeiro REDETEC. Rio de Janeiro, 2006, 25p.

[28] MORAIS, M. L.; SILVA, A. C. R.; ARAÚJO, C. R. R.; ESTEVES, E. A.; DESSIMONI-PINTO, N. A. V. Determinação do potencial antioxidante in vitro de frutos do cerrado brasileiro. Revista Brasileira de Fruticultura, Jaboticabal, v.35, n. 2, p. 355-360, 2013.

[29] MOTA, D.M. da; SCHIMITZ, H.; SILVA JUNIOR, J.F. da. Atores, canais de comercialização e consumo da mangaba no nordeste brasileiro. Revista de Economia e Sociologia Rural, Brasília, v.46, n.1, p.121-143, 2008.

[30] NARAIN, N.; FERREIRA, D. S.; ARAGAO, G. C.; ARAGAO, W. M. Tecnologia do processamento do fruto. In SILVA JUNIOR, J. F.; LEDO, A. S. A cultura da Mangaba. Embrapa Tabuleiros Costeiros, Aracaju, 220-232 p., 2005.

[31] OETTERER, M.; REGITANO-D’ARCE, M.A.B.; SPOTO, M.H. Fundamentos de Ciência e Tecnologia de Alimentos. São Paulo: Manole, 2006, 632p.

[32] OLIVEIRA, Z.L.; REGIS, A.A.; SOUSA, G.C.; SOUSA, P.A.; COELHO, E.L. Perfil microscópico de polpa congelada de maracujá comercializada em supermercados de Limoeiro do Norte - CE. Anais - VII Congresso Norte Nordeste de Pesquisa e Inovação. Palmas - Tocantins. Outubro. 2012 
[33] PAGLARINI, C. S.; SILVA, F. S.; PORTO, A. G.; SANTOS, P.; LEITE, A. L. M. P. Avaliação físico-química de polpas de frutas congeladas comercializadas na região do médio norte matogrossense. Enciclopédia Biosfera, Centro Científico Conhecer, Goiânia, vol. 7, n. 13, p. 1391-1398, 2011.

[34] PEREIRA, J.M.A.T.K.; OLIVEIRA, K.A.M.; SOARES, N.F.F.; GONÇALVES, M.P.J.C.; PINTO, C.L.O.; FONTES, E A.F. Avaliação da qualidade físico-química, microbiológica e microscópica de polpas de frutas congeladas comercializadas na cidade de viçosa - MG. Revista Alimentação e Nutrição, Araraquara, v.17, n.4, p.437-442, 2006.

[35] ROCHA, M. C.; SILVA, A. L. B.; ALMEIDA, A.; COLLAD, F. H. Efeito do uso de biofertilizante agrobio sobre as características físico-químicas na pós-colheita do maracujá-amarelo (Passiflora edulis f. flavicarpa Deg.) no município de Taubaté. Revista Biociências, Taubaté, v. 7, n. 2, p. 7-13, 2001. Disponível em: <http://periodicos.unitau.br/ojs2.2/index.php/biociencias/article/viewFile/426/262>. Acesso: 03 abr. 2013.

[36] ROSA, M. E. C.; NAVES, R. V.; OLIVEIRA JUNIOR, J. P. Produção e crescimento de mudas de mangabeira (Hancornia speciosa Gomes) em diferentes substratos. Pesquisa agropecuária tropical, Goiânia, v.35, n.2, p.65-70, 2005.

[37] SANTOS, D.P.; BARROS, B.C.V. Perfil higiênico sanitário de polpas de frutas produzidas em comunidade rural e oferecidas à alimentação escolar. Revista Brasileira de Tecnologia Agroindustrial, Ponta Grossa, v.6, n.2, p.747-756, 2012.

[38] SILVA JUNIOR, A. Processamento de frutos. Cadernos Tecnológicos. Edições Demócrito Rocha; CENTEC, 64p. $2004 b$.

[39] SILVA, F.A.S. Assistat 7.6 beta - assistência estatística. DEAG-CTRN-UFCG. Campina Grande. PB. Disponível em: <www.assistat.com/indexp.html>, Acesso: 06 jun. 2013

[40] SILVA JUNIOR, J.F. A cultura da mangaba. Revista Brasileira de Fruticultura, v.26, n.1, p.0-0, $2004 a$.

[41] SILVA, S. A.; CRUZ, E. M. de O.; REIS, R. V. dos; FERREIRA, C. F.; PASSOS, A. R. Caracterização morfológica e molecular de genótipos de mangaba. Revista Brasileira de Fruticultura, Jaboticabal, v. 35, n. 4, p. 1093-1100, 2013.

[42] SOARES JUNIOR, M.S.; CALIARI, M.; VERE, R.; SOUZA A.G. Conservação pós-colheita de mangaba sob refrigeração e modificação da atmosfera de armazenamento. Pesquisa Agropecuária Tropical, Goiânia, v.38, n.2, p.7886,2008

[43] SOARES, F. P.; PAIVA, R.; NOGUEIRA, R. C.; OLIVEIRA, L. M.; SILVA, D. R.; PAIVA, P. D. O. Cultura da Mangabeira (Hancornia speciosa Gomes). Boletim Agropecuário, Lavras, n. 67, 12p., 2006.

[44] SOUZA, F. G.; FIQUEIREDO, R. W.; ALVES, R. E.; MAIA, G. A.; ARAUJO,I. A. Qualidade pós-colheita de frutos de diferentes clones de mangabeira (Hancornia speciosa Gomes). Ciência agrotécnica. Lavras, v.31, n.5, p.1449-1454, 2007.

[45] SUCUPIRA, N.R.; XEREZ, A.C.P.; SOUSA, P.H.M. Perdas vitamínicas durante o tratamento térmico de alimentos. UNOPAR. Cient. Ciênc. Biol. Saúde, v.14, n.4, p.121-128, 2012. 


\section{Capítulo 2}

Estudo das características Físico-Químicas do melado comercializado no Seridó do RN

\section{Arivonaldo Bezerra da Silva \\ Isandra de França Medeiros \\ Ramon Araujo dos Santos \\ Daulton Ruan Rufino de Souza \\ Leonardo de Almeida Marciano}

Resumo: 0 melado é o caldo de cana-de-açúcar concentrado que atinge um ${ }^{\circ}$ Brix (teor de sólidos) entre 65\% e 75\%. A legislação que regulamenta esse produto é a resolução № 12 de 1978 da Comissão nacional de Normas e para Alimentos (CNNPA) do Ministério da Saúde, ela define o melado como "líquido" xaroposo obtido pela evaporação do caldo de cana (Saccharum officinarum L) ou a partir da rapadura, por processos tecnológicos adequados. Essa ainda estabelece os parâmetros para suas características físicoquímicas, que tem suma importância para estabelecer a qualidade do produto. Sendo assim, esse trabalho buscou realizar uma investigação físico-química de três melados vendidos na região Seridó do Rio Grande do Norte e compará-la aos parâmetros estabelecidos pela Resolução №12 de 1978 da CNNPA. Por fim, pôde-se observar que os melados analisados estão com os parâmetros físico-químicos em conformidade com a legislação, com a exceção da umidade dos melados A e B, que apresentaram valores um pouco acima dos propostos pela resolução CNNPA no 12 , de 1978, porem isso não torna os produtos impróprios para o consumo, podendo interferir apenas no tempo de prateleira dos mesmos.

Palavras-Chave: Cana de Açúcar, Qualidade, Xarope. 


\section{INTRODUÇÃO}

O cultivo de cana-de-açúcar no Brasil teve início logo após o seu descobrimento, sendo o primeiro engenho, que recebeu o nome de São Jorge dos Erasmos, implantado na capitania de São Vicente, próximo de onde hoje fica a cidade de Santos - SP. Seguido pelo engenho de Nossa senhora da Ajuda na capitania de Pernambuco, isso proporcionou a irradiação dos cultivos por todo o litoral brasileiro. A partir daí essa cultura teve altos e baixos, até que em 1933 foi criado o Instituto do Açúcar e do Álcool, afim de disciplinar a produção e controlar os mercados internos e externos.

De acordo com Carvalho (2007) "Para as pequenas propriedades rurais, a elaboração do melado é uma das formas lucrativas de beneficiar a cana, uma vez que o processo envolve equipamentos simples e em pequeno número, com possibilidade de trabalho com mão-de-obra da própria família."

Segundo Cesar, Silva e Silva (2003, P. 3), o melado é o caldo de cana-de-açúcar concentrado até atingir um ${ }^{\circ}$ Brix (teor de sólidos) entre 65\% e 75\%. A legislação que regulamenta esse produto é a resolução № 12 de 1978 da Comissão nacional de Normas e para Alimentos (CNNPA) do Ministério da Saúde, define o melado como "líquido" xaroposo obtido pela evaporação do caldo de cana (Saccharum officinarum L) ou a partir da rapadura, por processos tecnológicos adequados. Essa ainda estabelece os parâmetros para suas características físico-químicas, que tem suma importância para estabelecer a qualidade do produto.

Como a ingestão de alimentos se dá a fim de satisfazer as necessidades nutritivas e busca saciar as sensoriais, viu-se a necessidade e a importância de se conhecer a qualidade dos melados regionais oferecidos à população, bem como ter a garantia de se estar consumindo um produto nutritivo e saudável, de natureza inócua e que se encontre dentro dos padrões físico-químicos estabelecidos pela Resolução CNNPA no 12 de 1978 daí tornou-se inevitável a busca intensa por determinações que sejam determinantes da qualidade dos melados avaliados.

\section{METODOLOGIA}

Inicialmente, foram coletadas, no dia 05 de setembro de 2016, três amostras diferentes de melado de cana de açúcar no comércio regional. Em seguida, as amostras foram encaminhadas para o Laboratório de Análises Físico-Químicas de Alimentos do Instituto Federal de Educação, Ciência e Tecnologia do RN, Campus Currais Novos, e posteriormente identificadas como MELADO A, MELADO B e MELADO C.

As amostras foram submetidas às análises físico-químicas de $\mathrm{pH}$, condutividade, acidez, glicídios totais, umidade e resíduo mineral fixo (Cinzas).

As metodologias foram baseadas no Livro Métodos Físico-químicos para Análise de Alimentos. Instituto Adolfo Lutz. IV Edição.

Os resultados das análises foram tratados estatisticamente aplicando-se o desvio padrão amostral, para confiabilidade dos resultados. Para isso foi utilizada a planilha eletrônica MS Excel ${ }^{\circledR} 2013$.

\section{RESULTADOS E DISCUSSÃO}

Os resultados das análises físico-químicas dos melados de cana de açúcar comercializados na cidade de Currais Novos / RN, foram comparados com os parâmetros estabelecidos na resolução CNNPA no 12, de 1978, com exceção dos parâmetros de pH e condutividade que foram analisados afim de verificar uma possível discrepância entre as marcas vendidas na mesma cidade. Os resultados das análises seguem descritos abaixo:

Tabela 1 Médias dos resultados das análises físico-químicas realizadas nas três amostras de melado.

\begin{tabular}{|c|c|c|c|}
\hline \multirow{2}{*}{ Parâmetro } & \multicolumn{3}{|c|}{ Amostra } \\
\hline & MELADO A & MELADO B & MELADO C \\
\hline${ }^{*} \mathrm{pH}$ & $4,17( \pm 0,01)$ & $5,80( \pm 0,01)$ & $3,43( \pm 0,00)$ \\
\hline${ }^{*}$ Condutividade $(\mu \mathrm{S} / \mathrm{cm})$ & $1047,2( \pm 42,03)$ & $2,44( \pm 0,02)$ & $1248,67( \pm 34,22)$ \\
\hline$*$ Acidez (\%) & $4,97( \pm 0,12)$ & $4,90( \pm 0,11)$ & $5,25( \pm 0,04)$ \\
\hline * Glicídios totais (\%) & $75,25( \pm 0,00)$ & $72,5( \pm 0,00)$ & $82,25( \pm 0,00)$ \\
\hline * Umidade (\%) & $26,55( \pm 0,56)$ & $29,80( \pm 0,51)$ & $16,19( \pm 0,62)$ \\
\hline${ }^{*}$ Cinzas $(\%)$ & $0,90( \pm 0,03)$ & $2,01( \pm 0,05)$ & $1,02( \pm 0,04)$ \\
\hline
\end{tabular}


De acordo com a resolução CNNPA no 12, de 1978 o melado deve conter no máximo 10\% de acidez, o máximo de $25 \%$ de umidade, o máximo de $6 \%$ de cinzas e o mínimo de $50 \%$ de glicídios totais, sendo assim o MELADO $\mathrm{C}$ foi o único entre as três amostras que encontrasse de acordo com a legislação e os MELADOS A e B apresentaram teor de umidade superior ao traçado pela legislação. 0 maior teor de umidade nos melados A e B possivelmente estão relacionados ao menor tempo de cocção durante o processamento, o que também contribuiu para o menor conteúdo de glicídios totais, quando comparados com o Melado C.

\section{CONCLUSÕES}

Portanto os melados analisados estão com os parâmetros físico-químicos em conformidade com a legislação, com a exceção da umidade dos MELADOS A e B, que apresentaram valores um pouco acima dos propostos pela resolução CNNPA no 12, de 1978, que serviu de referência para este trabalho, porem isso não torna os produtos impróprios para o consumo, podendo interferir apenas no tempo de prateleira dos mesmos.

\section{REFERÊNCIAS}

[1] Anvisa - Agência Nacional de Vigilância Sanitária. Resolução - CNNPA no 12, de 1978. Disponível em: http://www.anvisa.gov.br/anvisalegis/resol/12_78_melaco.htm. Acesso em: 12/09/2016.

[2] Cesar, M. A. A.; Silva, F. C.; Silva, C. A. B. Pequenas Industrias Rurais Da Cana-De-Açúcar: Melado, Rapadura e Açúcar Mascavo. 1aㅡ Edição. Brasília: Embrapa, 2003. 155 p.

[3] Instituto Adolfo Lutz. Métodos físico-químicos para análise de alimentos. IV Edição -1ª Edição digital. São Paulo, 2008. Disponível em: <http://www.ial.sp.gov.br/ial/publicacoes/livros/metodos-fisico-quimicos-para-analisede-alimentos $>$. Acesso em: 20/07/2015. 


\section{Capítulo 3}

Elaboração e perfil físico-químico e microbiológico de farinha de cabeça de Tilápia do Nilo Creochromis Niloticus)

\section{Denise Pastore de Lima}

Katiane Aparecida Willy

Daiane Aparecida dos Santos

Resumo: Este trabalho teve como objetivo desenvolver farinha de cabeça de tilápia do Nilo (Oreochromis niloticus) e avaliar as características físico-químicas e microbiologias. As cabeças foram lavadas, cozidas, prensadas, moídas, secadas e novamente moídas para a obtenção da farinha. Foram realizadas análises de composição centesimal, pH, Aw, cor e microbiológicas de contagem total de bactérias a $20^{\circ} \mathrm{C}$ e $35^{\circ} \mathrm{C}$, coliformes a $35^{\circ} \mathrm{C}$ e $45^{\circ} \mathrm{C}$, Escherichia coli, Estafilococos coagulase positiva e presença de Salmonella sp. As análises mostraram que a farinha de cabeça de tilápia apresentou resultados das análises físicoquímicas e microbiológicas permitidos pela legislação e de acordo com os encontrados por outros autores. 0 produto se mostrou um alimento nutritivo e uma opção para o aproveitamento dos resíduos da filetagem da tilápia podendo ser utilizado na alimentação para humanos e animais.

Palavras-Chave: resíduos; filetagem; alimentação humana. 


\section{INTRODUÇÃO}

O pescado é a carne mais demandada mundialmente (SIDONIO et al., 2012) e de maior valor de mercado. Porém, no Brasil, seu consumo ainda é baixo, mesmo tendo aumentado nos últimos anos para 11,17 kg por habitante ano, valor ainda abaixo do mínimo recomendado pela Organização Mundial de Saúde, que é de $12 \mathrm{~kg}$ por habitante ano (FOOD AND AGRICULTURE ORGANIZATION OF THE UNITED NATIONS, 2012). Segundo Pacheco (2004), a tilápia é um peixe com grande capacidade de adaptação, elevada resistência a doenças, atingindo peso comercial em pequeno intervalo de tempo, além da alta qualidade de sua carne e também por apresentar elevada aceitação no mercado consumidor. Considerando que estes resíduos contem proteína e de outros nutrientes que poderiam ser utilizados para a produção de alimentos nutritivos e de baixo custo, a agregação de valor a estes produtos torna-se uma alternativa viável de exploração comercial reduzindo a geração de resíduos orgânicos (GONÇALVEIS, 2011). Os resíduos da tilápia apresentam grande qualidade nutricional, contendo vitamina B3 e D, potássio, fósforo, cálcio, sódio, e outros minerais essenciais, por esse motivo não devem ser desprezados, uma vez que estes apesar de ser essenciais para a saúde humana agridem irreversivelmente o meio ambiente (ABREU et al., 2012). A farinha de peixe é pouco valorizada na nutrição humana, tendo-se poucos estudos diante desse assunto. 0 alto valor nutricional encontrado em sua composição agrega valor ao produto bem como incentiva a um desenvolvimento sustentável (GODOY et al., 2010). 0 objetivo do presente trabalho foi desenvolver farinha de carcaça de tilápia do Nilo (Oreochromis niloticus) e avaliar as características físico-químicas e microbiologias.

\section{MATERIAL E MÉTODOS}

A metodologia utilizada para a obtenção da farinha segue o processo descrito por Franco et al. (2013), com adaptações. As cabeças foram obtidas de um pesque e page localizado na região Oeste do Paraná, lavadas, cozidas em panela de pressão, por 60 minutos. Após, as cabeças foram prensadas, resultando numa torta, a qual foi triturada em um triturador Cutter Skymsen ${ }^{\circledR}$ (model PSEE98MHD). 0 produto triturado foi secado uma estufa Quimis ${ }^{\circledR}$ (modelo Q317B) a temperatura de $60^{\circ} \mathrm{C}$ por 24 horas. Após o produto foi moído em um moinho de facas SOLAB ${ }^{\circledR}$ (modelo CE-430/Mini) obtendo-se assim, a farinha de cabeça de tilápia, conforme mostra a Figura 1. A farinha foi embalada em embalagem plástica e mantida a temperatura ambiente até a realização das análises.

Figura 1 - Farinha de cabeça de tilápia

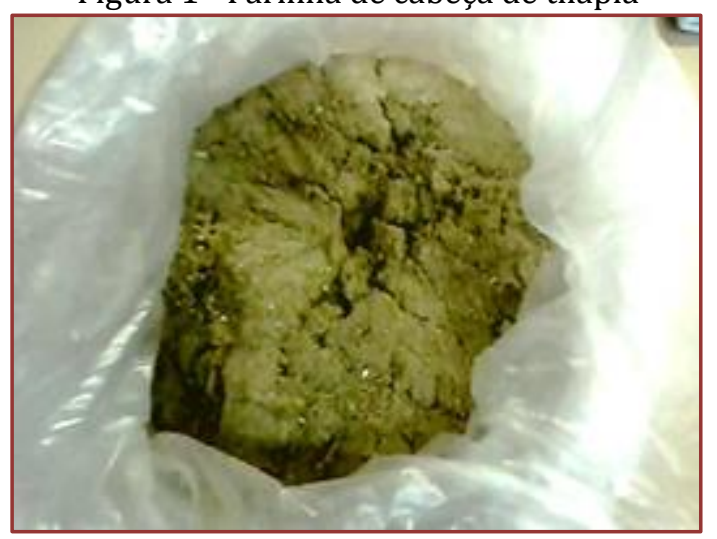

As medidas de $\mathrm{pH}$ foram realizadas sob temperatura ambiente utilizando potenciômetro (modelo $\mathrm{pH} 21$, Hanna ${ }^{\circledR}$ ), homogeneizou-se $10 \mathrm{~g}$ de amostra com $50 \mathrm{~mL}$ de água destilada. Os teores de umidade, cinzas, lipídeos e proteína bruta foram determinados de acordo com procedimento descrito pela Association Official Analytical Chemists (2006). Para a medida da cor foi utilizado o colorímetro Minolta ${ }^{\circledR}$ (modelo CR 400 ), com iluminante D65 e ângulo de visão de $10^{\circ}$. As medidas de cor foram realizadas em três diferentes pontos sobre o produto e expressas conforme o sistema de cor da Commission Internationale de $L^{\prime}$ Eclairage (CIELAB). A atividade de água (Aw) foi avaliada a $25^{\circ} \mathrm{C}$ em determinador de atividade de água Aqualab $^{\circledR}$ (modelo 4TE). 
As análises microbiológicas de Coliformes a $45^{\circ} \mathrm{C}$ e $35^{\circ} \mathrm{C}$, Estafilolococcus coagulase positiva, Escherichia coli, Contagem bacteriana total a $20^{\circ} \mathrm{C}$ e a $35^{\circ} \mathrm{C}$ e presença de Samonella sp., foram realizadas, conforme Instrução Normativa no 62 , do MAPA (BRASIL, 2003). Os resultados foram comparados com a legislação (BRASIL, 2001; ICMSF, 1982).

\section{RESULTADOS E DISCUSSÃO}

Conforme mostra a Tabela 1, a farinha apresentou valores de umidade e proteína próximo ao encontrado por Stevanato (2006), em farinha de cabeça de tilápia do Nilo (6,01\% de umidade e 38,41\% de proteína) e de Galan et al. 2013 (3,06\% de umidade, 33,80\% de proteína bruta). Fuzinatto et al. (2015), em pesquisa realizada com o mesmo tipo de farinha indicou valores de cinzas $(33,00 \pm 2,39)$, lipídios $(15,05 \pm 1,79)$, Aw $(0,09 \pm 0,02)$, similares aos obtidos neste trabalho. Neiva (2008) encontrou pH de 6,77 para farinha de CMS de pescado cozida após secagem, estando este valor próximos aos encontrado para farinha de cabeça de tilápia. Coloração mais clara $\left(\mathrm{L}^{*}\right)$, menor intensidade de vermelho (a*) e amarelo mais intenso ( $\left.{ }^{*}\right)$ foi observado, que em estudo realizado em farinha de cabeça de tilápia do Nilo por Fuzinatto et al. (2015).

Tabela 1 - Resultados das análises físico-químicas e instrumentais de farinha de cabeça de tilápia.

\begin{tabular}{|c|c|}
\hline Parâmetros & Farinha de cabeça de tilápia \\
\hline Proteína (\%) & $41,40 \pm 0,80$ \\
\hline Umidade (\%) & $3,36 \pm 0,08$ \\
\hline Cinzas (\%) & $32,65 \pm 0,17$ \\
\hline Lipídeos (\%) & $17,87 \pm 1,14$ \\
\hline Aw & $0,10 \pm 0,50$ \\
\hline pH & $6,70 \pm 0,05$ \\
\hline Cor L & $61,75 \pm 0,02$ \\
\hline Cor $^{*}$ & $1,04 \pm 0,01$ \\
\hline Cor b $^{*}$ & $20,57 \pm 0,02$ \\
\hline
\end{tabular}

Os resultados estão representados pela média \pm erro padrão $(n=3)$

As enumerações de Coliformes a $35^{\circ} \mathrm{C}$ e $45^{\circ} \mathrm{C}$, E. Coli e E. coagulase positiva não apresentaram contagens e não foi detectada a presença de Salmonella sp. na amostra de farinha (Tabela 2). As contagens total de bactérias a $20^{\circ} \mathrm{C}$ e a $35^{\circ} \mathrm{C}$ apresentaram valores permitidos pela legislação. Os resultados das análises microbiológicas atendem a legislação nacional e internacional (BRASIL, 2001; ICMSF, 1992).

Tabela 2 - Resultados das análises microbiológicas da farinha de cabeça de tilápia.

\begin{tabular}{|c|c|c|}
\hline Parâmetro & Resultado & Legislação \\
\hline Contagem de Coliformes a 35ํㅡ (NMP/g) & $<3,0$ & \\
\hline Contagem de Coliformes a $45^{\circ} \mathrm{C}(\mathrm{NMP} / \mathrm{g})$ & $<3,0$ & $10^{2^{*}}$ \\
\hline Contagem de Escherichia coli (NMP/g) & $<3,0$ & $11^{* *}$ \\
\hline Contagem de Total de Bactéria a 20ㅡㄷ (Log.UFC/g) & $2,43 \pm 0,55$ & $5 \times 10^{5^{* *}}$ \\
\hline Contagem de Total de Bactéria a 35ํㅡ (Log.UFC/g) & $2,47 \pm 0,49$ & $5 \times 10^{5 * *}$ \\
\hline Contagem de Estafilococos coagulase Positiva (UFC/g) & $<10^{2}$ & $5 \times 10^{2^{*}}$ \\
\hline Presença de Salmonella sp. em 25g & Ausência em $25 \mathrm{~g}$ & Ausência em $25 \mathrm{~g}$ \\
\hline
\end{tabular}

\section{CONCLUSÕES}

De acordo com os resultados físico-químicos e microbiológicos pode-se verificar que a farinha de cabeça de tilápia apresentou valores permitidos pela legislação e de acordo com os encontrados por outros autores sendo uma opção alimentar para animais e humanos. A farinha de cabeça se apresentou como um alimento nutritivo, uma opção para o aproveitamento do resíduo da filetagem da tilápia e podendo ajudar a preservar o meio ambiente. 


\section{AGRADECIMENTOS}

Os autores agradecem à Universidade Tecnológica Federal do Paraná pelo apoio à realização deste estudo.

\section{REFERÊNCIAS}

[1] Abreu, B., Franco, M.L., Gasparino, E., Vieira, V. (2012). Composição química, análise microbiológica e sensorial de bolachas enriquecidas com farinha de peixe. III Simpósio de Gestão do Agronegócio e III Amostra de Trabalhos Científicos. Disponível em: http://www.dzo.uem.br/pet/docs/docs/anais12.pdf. Acesso em 30 de outubro de 2014.

[2] Association Methods of Analysis of AOAC International (2006)-Volume I and II, 18th Edition,(Rev. 1).

[3] Brasil, Agência Nacional de Vigilância Sanitária (2001). Regulamento Técnico Sobre Padrões de Microbiológicos para Alimentos. (Resolução RDC no 12, de 2 de janeiro de 2001). Diário Oficial da República Federativa do Brasil.

[4] Brasil, Ministério da Agricultura Pecuária e Abastecimento (2003). Oficializa os Métodos Analíticos Oficiais para Análises Microbiológicas para Controle de Produtos de Origem Animal e Água. Secretaria de Defesa Agropecuária. (Instrução normativa no 62, de 26 de agosto de 2003). Diário Oficial da República Federativa do Brasil.

[5] Food and Agriculture Organization. The State of Word Fisheries and Aquacuture. Fisheres and Aquaculture Department. Rome: FAO, 2012.

[6] Franco, M.L.R.S., Abreu B.B., Saccomani, A.P.O., Vieira, V., Del Vesco, A.P., Mikcha, J.M.G., Gasparino, E., Adelbem, A. (2013). Elaboración de cookies y galletas con inclusión de harina de pescado. Infopesca Internacional. Montevideo, Uruguay. (53) 30-33.

[7] Fuzinatto, M.M., Lima, D.P., Andretto, A.P., Menezes, L.A., Souza, A.H.P., Franco, M.L.S., Steinmacher, N.C., Mendonça, S.N.T.G., Vargas, L. (2015). Influence of a homeopathic product on performance ando n quality flour and cookie (Grissini) of Nile tilapia. Afr. J. Pharm. Pharmacol. (9)675-683.

[8] Galan, G.L., Franco, M.L.R.S., Souza, E.D., Scapinello, C., Gasparino, E., Visentainer, J.V., Vesco, A.P.D. (2013). Farinha de cabeça de Tilápia em dietas para coelhos: composição química e resistência óssea. Semina: Ciências Agrárias, Londrina, (34)5 2473-2484.

[9] Godoy, L.C., Franco, M.L.R.S., Franco, N.P., Silva, A.F., Assis, M.F., Souza, N.E., Matsushita, M., Visentainer, J.V. (2010). Análise sensorial de caldos e canjas elaborados com farinha de carcaças de peixe defumadas: aplicação na merenda escolar. Ciência Tecnologia de Alimentos, Campinas, 30(Supl.1): 86-89.

[10] Gonçalves, A.A. Tecnologia do pescado: Ciência, Tecnologia, Inovação e Legislação (2011). Editora Atheneu. São Paulo: Editora Atheneu, 608p.

[11] ICMSF. International Commission of Microbiological Specifications for Foods (1982). Microorganimsm in foods. Their significance and methods of enumeration. (2nd ed.) Universityof Toronto Press, Toronto. $436 \mathrm{p}$.

[12] Neiva, C.R.P. (2008). Processamento, avaliação nutricional e aceitabilidade de produtos à base de pescado desidratado: sopa e biscoito. Tese. Pós-graduação ao titulo de Doutor em Saúde Pública. Universidade de Saúde Pública de São Paulo- SP. 187 p.

[13] Pacheco, D. O peixe de ouro da aquicultura brasileira. Revista Nacional da Carne, edição n 325, março, 2004.

[14] Sidonio, L. Experiências Internacionais aquícolas e oportunidades de desenvolvimento da aquicultura no Brasil: proposta de inserção do BNDES (2012). Agroindústria. BNDES Setorial, (36) 179-218.

[15] Stevanato, Flávia Braidotti. Aproveitamento de cabeças de tilápias de cativeiro na forma de farinha como alimento para merenda escolar. Maringá, Junho de 2006. Disponível < http://www.dqi.uem.br/posgraduacao/arquivos/documentos/me172c.pdf >. Acesso em 25 de outubro de 2014. 


\title{
Capítulo 4
}

Qualidade físico-química e microbiológica marcas comerciais de mel de engenho comercializadas em João Pessoa-PB, Brasil

\author{
Roberto Kelwin Lopes da Costa e Lopes \\ Edilma Pinto Coutinho \\ Anderson Ferreira Vilela \\ Marcelo Barbosa Muniz \\ Kerolayne Santos Leite \\ José Honório Pereira Lopes Neto \\ Amanda da Silva Gomes \\ Helenice Duarte de Holanda
}

Resumo: 0 objetivo desse trabalho foi avaliar as características físico-químicas e microbiológicas de três marcas comerciais de mel de engenho, comercializadas na cidade de João Pessoa - PB. Foram realizadas análises físico-químicas de pH, acidez total, umidade, cinzas, sólidos solúveis, açúcares redutores, açúcares totais e açúcares nãoredutores, em sacarose, todas as análises foram realizadas em triplicata. As análises microbiológicas realizadas foram coliformes à 35 e $45{ }^{\circ} \mathrm{C}$ e contagem de aeróbios mesófilos em placa. 0 pH das amostras variou de 3,9 a 4,8; a acidez de 3,68 a 4,57 v/m e os açúcares totais de 67,92 a $71,48 \mathrm{~m} / \mathrm{m}$. Todas as amostras apresentaram resultados negativos para coliformes e aeróbios mesófilos, portanto, estão em conformidade com a legislação em vigor.

Palavras-chave: fonte de minerais; estabilidade microbiológica; teor de açúcares. 


\section{INTRODUÇÃO}

O mel de engenho é o xarope obtido pela evaporação, concentração e limpeza do caldo de cana, contendo em média de 65 a $75{ }^{\circ}$ Brix. Quando usado em alimentos, o mel de engenho agrega sabor e cor característicos. É um produto bastante consumido no Nordeste do Brasil, como também nas demais regiões, e vem sendo muito usado na gastronomia regional (SEBRAE, 2015, GASPAR, 2012, MACHADO, 2011).

Segundo estudos de Ribeiro et al. (2012) e CISB (2009), o mel de engenho, também chamado de "rapadura líquida", devido às semelhanças sensoriais, é um alimento doce, de cor escura e textura semelhante ao mel, é mais saudável que o açúcar comum, pois preserva alguns nutrientes da cana-de-açúcar, sendo usado como fonte de vitaminas e minerais.

Carvalho (2007) ressalta que o mel de engenho é consumido puro ou em misturas com outros alimentos, tais como a farinha de mandioca, o queijo e biscoitos. 0 mesmo autor aponta ainda o uso do mel de engenho em empresas de confeitaria e bebidas, entre outros, como ingrediente no processamento de seus produtos.

Ainda segundo Carvalho (2007), o mercado de produtos como o mel de engenho e a rapadura diminuíram com o surgimento das tecnologias de produção do açúcar refinado, todavia, com o aumento da demanda por produtos naturais, esse mercado tende a crescer novamente.

Baseado nesse contexto e considerando a escassez de trabalhos científicos relativos ao mel de engenho, este trabalho objetivou avaliar as características físico-químicas e microbiológicas de três marcas comerciais de mel de engenho, comercializadas na cidade de João Pessoa - PB.

\section{MATERIAL E MÉTODOS}

As três marcas comerciais de mel de engenho foram adquiridas em diferentes pontos de comercialização da cidade de João Pessoa, sendo duas amostras produzidas na Paraíba e uma produzida em Pernambuco.

As amostras foram transportadas em sacos de polietileno, à temperatura ambiente, para o Laboratório de Tecnologia de Alimentos, do Centro de Tecnologia, da Universidade Federal da Paraíba, Campus I, João Pessoa, onde foram submetidas às análises físico-químicas e microbiológicas.

As análises físico-químicas realizadas foram: $\mathrm{pH}$, utilizando potenciômetro da marca Quimis, previamente calibrado; acidez total, onde $10 \mathrm{~g}$ da amostra foi pesada e diluída em $40 \mathrm{~mL}$ de água destilada, sendo a solução resultante titulada com solução de $\mathrm{NaOH} 0,1 \mathrm{~N}$; umidade, utilizando estufa a $105{ }^{\circ} \mathrm{C}$, até peso constante; cinzas, por incineração em mufla à $550{ }^{\circ} \mathrm{C}$; sólidos solúveis, por refratometria, utilizando refratômetro de campo, nº 3, marca ATAGO; açúcares redutores e açúcares totais, por titulação com licor de Fehling, obtendo os dados de açúcares não-redutores, em sacarose, por diferença (IAL, 2008). Todas as análises foram realizadas em triplicata.

As análises microbiológicas realizadas foram: coliformes à 35 e $45{ }^{\circ} \mathrm{C}$, pelo método do número mais provável (NMP), com leitura dos resultados obtidos na série de três tubos, e contagem de aeróbios mesófilos em placa, por plaqueamento em ágar PCA (SILVA et al., 2007).

\section{RESULTADOS E DISCUSSÃO}

Os resultados das análises físico-químicas dos méis de engenho seguem apresentados na Tabela 1 . As amostras de mel de engenho apresentaram valores de açúcares totais variando de $67,92 \%$ a $71,48 \%$, que não diferiram significativamente entre si. Quanto ao teor de açúcares redutores, todas as amostras apontaram diferença significativa entre si, apresentando concentrações acima de 30\%. 
Tabela 1 - Análises físico-químicas de mel de engenho comercializado na cidade de João Pessoa, 2016

\begin{tabular}{|c|c|c|c|}
\hline \multirow{2}{*}{ Parâmetros } & \multicolumn{3}{|c|}{ Amostras } \\
\hline & A & B & $\mathrm{C}$ \\
\hline Umidade $(\% \mathrm{~m} / \mathrm{m})$ & $24,48 a \pm 0,97$ & $23,32 \mathrm{a} \pm 0,87$ & $22,41 \mathrm{a} \pm 0,58$ \\
\hline Cinzas $(\% \mathrm{~m} / \mathrm{m})$ & $1,44 a \pm 0,10$ & $1,14 a \pm 0,07$ & $0,46 b \pm 0,12$ \\
\hline $\mathrm{pH}$ & $4,80 a \pm 0,02$ & $4,79 a \pm 0,01$ & $3,99 b \pm 0,01$ \\
\hline Acidez $(\% \mathrm{v} / \mathrm{m})$ & $4,57 a \pm 0,01$ & $3,68 c \pm 0,04$ & $4,30 b \pm 0,04$ \\
\hline Sólidos solúveis ( ${ }^{\circ} \mathrm{Brix}$ ) & $77,80 \mathrm{~b} \pm 0,00$ & $78,20 \mathrm{a} \pm 0,00$ & $77,20 \mathrm{c} \pm 0,00$ \\
\hline Açúcares totais $(\% \mathrm{~m} / \mathrm{m})$ & $67,92 \mathrm{a} \pm 1,97$ & $71,48 a \pm 1,00$ & $70,23 a \pm 0,03$ \\
\hline Açúcares redutores $(\% \mathrm{~m} / \mathrm{m})$ & $33,04 c \pm 0,00$ & $43,36 a \pm 0,00$ & $36,76 b \pm 0,00$ \\
\hline Açúcares não-redutores, em sacarose $(\% \mathrm{~m} / \mathrm{m})$ & $34,87 a \pm 1,97$ & $28,12 b \pm 1,00$ & $33,47 a \pm 0,03$ \\
\hline
\end{tabular}

*Letras diferentes na mesma linha diferem estatisticamente $(\mathrm{P}<0,05)$ entre si pelo teste de Tukey.

Fonte: Próprio autor.

Carvalho (2007) relata que a concentração mínima de açúcares totais no mel de engenho é de 50\%, podendo alcançar valores superiores a 74\%; o autor escreve ainda que a concentração do mel está diretamente ligada ao rendimento do processo e à vida útil do produto, em razões inversas, quanto mais concentrado, menor o rendimento e maior a vida de prateleira do produto.

Ainda conforme Carvalho (2007), a presença de açúcares redutores em mel de engenho se dá pela inversão da sacarose, que é realizada durante o processamento para evitar que o produto cristalize após embalado; essa etapa é feita por adição de ácido cítrico durante a concentração do caldo quando este se encontra, em média, com teor de sólidos solúveis em volta de 50 e $60^{\circ}$.

Cesar e Silva (2003) apontam a inversão da sacarose, pela adição do ácido cítrico, como responsável pela redução do $\mathrm{pH}$, próximo a 4,0, e o aumento da acidez do produto, como pode ser observado ainda na Tabela 1, além de aumentar o teor de açúcares redutores do mel de engenho à valores superiores a 20\%.

Comparando os dados da Tabela 1 com os estabelecidos pela Resolução n 12 de 1978, da CNNPA, é possível observar que as amostras analisadas estão de acordo com o estabelecido pela legislação em vigor (BRASIL, 1978).

Os resultados das análises microbiológicas do mel de engenho estão registrados na Tabela 2. Todas as amostras se apresentaram em conformidade quanto às análises microbiológicas. Quando comparados esses resultados com os parâmetros pré-estabelecidos pela Resolução $n^{\circ} 12$ de 1978, da CNNPA, que determina ausência de coliformes em $1 \mathrm{~g}$ da amostra e de salmonela em $25 \mathrm{~g}$ da amostra, observa-se que as três amostras estão em acordo com a legislação, em relação à contagem de coliformes (BRASIL, 1978). Em relação a contagem de aeróbios mesófilos, a legislação vigente não estabelece padrões para o mel de engenho, todavia a ausência desse grupo microbiano indica boa qualidade microbiológica das amostras analisadas.

Tabela 2 - Análises microbiológicas do mel de engenho comercializado na cidade de João Pessoa, 2016

\begin{tabular}{|c|c|c|c|}
\hline \multirow{2}{*}{ Parâmetros } & \multicolumn{3}{|c|}{ Amostra } \\
\hline & A & B & Ausente \\
\hline Coliformes à $35^{\circ} \mathrm{C}$ & Ausente & Ausente & Ausente \\
\hline Coliformes à $45^{\circ} \mathrm{C}$ & Ausente & Ausente & Ausente \\
\hline Aeróbios mesófilos & Ausente & Ausente & Ausente \\
\hline
\end{tabular}

Fonte: Próprio autor. 
Por ser produzido sob altas temperaturas e envasado ainda quente, já era esperado uma baixa contagem de microrganismos presentes nos meios avaliados. Alvarez e Carvalho Filho (2012) ressaltam que a temperatura em que o mel de engenho é obtido esteriliza o produto final, além de modificar algumas características originais do caldo de cana.

É válido ainda salientar que o baixo pH do produto, assim como a alta concentração de sólidos solúveis, são também fatores que contribuem para uma elevada conservação do alimento, pois prejudica o crescimento de microrganismos.

\section{CONCLUSÃO}

As três amostras de mel de engenho apresentaram boa qualidade físico-química, desta forma, o $\mathrm{pH}$, a acidez, os sólidos solúveis e os açucares totais e redutores são compatíveis com o tipo de produto. Em relação a qualidade microbiológica, todas as amostras apresentaram resultados negativos para coliformes à 35 e $45^{\circ} \mathrm{C}$ e aeróbios mesófilos, portanto, estão em conformidade com a legislação em vigor.

\section{REFERÊNCIAS}

[1] Alvarez, R. C., \& Carvalho Filho, C. D. (2012). Análise Comparativa da Composição Química das Aguardentes Produzidas com Caldo de Cana e Melado. Revista Brasileira de Produtos Agroindustriais, 14(2), 149-154.

[2] Brasil, Comissão Nacional de Normas e Padrões para Alimentos. (1978). Aprova Normas Técnicas Especiais, do Estado de São Paulo, revistas pela CNNPA, relativas a alimentos (e bebidas), para efeito em todo território brasileiro (Resolução no 12 de 24 de julho de 1978). Diário Oficial [da] República Federativa do Brasil.

[3] Carvalho, R. F. (2007). Beneficiamento dos derivados da cana de açúcar (melado e -açúcar mascavo). Dossiê Técnico. Rede de Tecnologia da Bahia - RETEC - BA.

[4] Cesar, M. A. A., \& Silva, F. C. (2003). Pequenas Industrias Rurais da Cana-de-Açúcar: melado, rapadura e açúcar mascavo. In: SILVA, F. C., Cesar, M. A. A., Silva, C. A. B. Pequenas Industrias Rurais de Cana-de-açúcar: melado, rapadura e açúcar mascavo. Embrapa.

[5] CISB. Conselho de Informações sobre Biotecnologia (2009). Guia da cana-de-açúcar: avanço científico beneficia o país.

[6] Gaspar, L. (2012). Mel de engenho (melado). Pesquisa Escolar Online, Fundação Joaquim Nabuco, Recife. Disponível em: <http://basilio.fundaj.gov.br/pesquisaescolar/>.

[7] Instituto Adolfo Lutz (2008). Normas Analíticas do Instituto Adolfo Lutz. Métodos Químicos e Físicos para Análise de Alimentos (1 ed. Online). São Paulo: IAL.

[8] Machado, D. L. L. (2011). Transformações no Mercado de Melado de Cana-de-Açúcar para os Produtores de Santo Antônio da Patrulha, Participantes do Programa Puro Engenho (Trabalho de Conclusão de Curso). Universidade Federal do Rio Grande do Sul, Departamento de Ciências Econômicas.

[9] Ribeiro, J. M., Melo, N. F., Coelho, Â. K. N. S., \& Pinto, M. S. T. (2012). Efeito do melado de cana-de-açúcar no desenvolvimento in vitro de bananeira (Musa spp.) cv. Maçã. Revista Ceres, 59(3), 293-298.

[10] SEBRAE, Serviço Brasileiro de Apoio às Micro e Pequenas Empresas (2015). A Fabricação do Melado. Disponível em: <http://www.sebrae.com.br/sites/PortalSebrae/artigos/A-fabrica\%C3\%A7\%C3\%A3o-do-melado>. 


\section{Capítulo 5}

Caracterização do maná-cubiu (Solanum sessiliflorum Dunal) produzido na mata atlântica do Estado do Paraná

Aiane Benevide Sereno

Marlene Bampi

Luciana Gibbert

Francis José Zortea Merino

Renata Labrocini Bertin

Claudia Carneiro Hecke Krüger

Resumo: 0 maná-cubiu (Solanum sessiliflorum Dunal) pertence à família Solanaceae, considerada a mais importante para a agricultura mundial, esse fruto da biodiversidade brasileira foi introduzido como alternativa de renda aos agricultores da Mata Atlântica nos municípios de Morretes e Antonina. Seu sabor e característica exótica permite sua utilização em diversos produtos, incluindo preparações gourmet em restaurantes da capital do Estado do Paraná. Devido à sua variabilidade genética, e à escassez de estudos sobre suas características quando cultivado no Sul do Brasil, justifica-se a importância desse estudo. 0 trabalho objetivou caracterizar o fruto do Solanum sessiliflorum Dunal produzido no litoral do Paraná. Foram realizadas as caracterizações físicas e físicoquímica: comprimento, diâmetro, densidade, massa e rendimento, incluindo os teores de acidez, determinação de ácidos orgânicos e pH. Os frutos foram coletados na Associação de Pequenos Produtores Rurais e Artesanais de Antonina (ASPRAN). Os resultados obtidos foram: peso médio de $83,91 \pm 20,47 \mathrm{~g}$, densidade $0,93 \mathrm{~g} / \mathrm{cm}^{3}$, comprimento $5,49 \pm 0,20 \mathrm{~cm}$ e diâmetro $5,46 \pm 0,03 \mathrm{~cm}$. Seu rendimento correspondeu 86\% do peso do fruto. As determinações de suas características permitem a expansão de sua produção e a obtenção de novos produtos.

Palavras-chave: Maná-cubiu; Cocona; Solanum sessiliflorum Dunal; Caracterização. 


\section{INTRODUÇÃO}

O Solanum sessiliflorum Dunal foi domesticado pelos índios da Amazônia Ocidental sendo utilizado no tratamento de queimaduras e para dar brilho aos cabelos, ficando conhecido pelos nomes: Manacubiu, maná-cubiu, cocona, cubiu e na língua Tupi chama-se Kubi'u. Essa planta pode ser encontrada em toda costa da Amazônia, Peru, Equador, Colômbia e Venezuela (OLIVEIRA, 1999; SILVA, 2002). 0 maná-cubiu, pertence à família Solanaceae, sendo esta uma das mais importantes para a agricultura mundial. As principais espécies são o tomateiro, a batata, berinjela e a pimenta, as quais representam os hábitos alimentares das populações de diversas culturas (SEQUI, 2016).

O maná-cubiu foi trazido para o litoral do estado do Paraná em 2015 por meio do projeto RAPPs (Restauração de Áreas de Preservação Permanente) passando a ser cultivada nos municípios de Antonina e Morretes (BOLDRINI, PAES e PINHEIRO, 2016). A Mata Atlântica é composta por um conjunto de fauna e flora com ecossistemas associados a restingas, manguezais e campos. Atualmente sua vegetação nativa está reduzida com diferentes estágios de regeneração. Mesmo com esta alteração, estima-se que existam cerca de 20.000 espécies vegetais, compreendendo $35 \%$ das existentes no Brasil, incluindo diversas espécies ameaçadas de extinção. Apesar da vasta diversidade biológica a monotonia alimentar encontra-se presente nos hábitos alimentares da população brasileira (BRASIL, 2017).

Considerando a monotonia alimentar instalada na população, é necessário incluir estratégias para garantia do consumo de alimentos regionais, visando à promoção da biodiversidade, assim como a caracterização dos frutos de acordo com seu genótipo para produção de produtos e subprodutos. 0 manácubiu pode ser consumido de diversas maneiras: geleias, compotas, polpa da fruta, sorvetes, molhos e temperos para preparações com peixes e frangos. Além disso, por possuir sabor ligeiramente ácido, tem sido explorado em preparações de pratos gourmets em restaurantes da cidade de Curitiba. 0 interesse pelo fruto tem permitido a expansão de sua produção, assim como o avanço em pesquisas científicas acerca dos benefícios para a saúde pelo consumo do fruto. (PEREIRA, 2001; GILSON, 2016)

o maná-cubiu exibe quantidades significativas de selênio, fósforo e ferro o qual contribui significativamente com as Recommended Dietary Allowances (RDAs) de acordo com o estudo realizado por Sereno et al., 2018. 0 valor nutricional dos frutos está diretamente correlacionado com seus teores de minerais, haja vista que os minerais desempenham funções na prevenção de diversas doenças, tais como a desmineralização óssea, a hipertensão arterial e o risco cardiovascular, assim como os compostos bioativos presente no maná-cubiu que garante a capacidade antioxidante na prevenção e promoção da saúde (FAWOLE, OPARA, 2012; SERENO, 2018).

Estudos demonstraram que a farinha de maná-cubiu exerce efeito hipolipemiante, diminuindo o colesterol total, aumentando a excreção do colesterol fecal e diminuindo o colesterol hepático, além de exercer influência sobre a concentração sérica da glicose e diminuir os níveis de ácido úrico no sangue (YUYAMA et al., 2005; MAIA, 2015). Devido a variabilidade morfológica do fruto e a escassez de estudos desta espécie, proveniente da Mata Atlântica do Paraná, e o crescente interesse por estudos com frutos da biodiversidade brasileira justifica-se a importância da realização desse estudo, o qual tem por objetivo caracterizar o fruto do Solanum sessiliflorum Dunal.

\section{MATERIAL E MÉTODOS}

A coleta dos frutos foi realizada na cidade de Morretes com coordenada geográfica 2516'31"sul e 48운'55" oeste. Os frutos inclusos consistia de frutos sem rachaduras, em coloração marrom café (Figura 1). 0 material foi botanicamente identificado no Museu Botânico Municipal e se depositou uma exsicata no Herbário Municipal (n. - 379033). Para caracterização física foram selecionados 25 frutos. Utilizou-se balança digital (Adventurer AR2140®). As medidas de comprimento e diâmetro máximo foram realizadas com auxílio de paquímetro digital com precisão de $0,01 \mathrm{~mm}$ (Lee Tools $684132 \AA$ ). A determinação do volume foi realizada por deslocamento de água, conforme Ferreira (2002) para posterior determinação da densidade. Para avaliar o rendimento, os frutos foram cortados manualmente, sendo separada a polpa com sementes da casca e pedúnculos.

A caracterização do potencial hidrogênico (pH) (AOAC no 942.15, 2000), acidez titulável (AOAC n 942.15, 2000) seguiu a metodologia da Association of Official Chemists (AOAC, 2000), e os sólidos solúveis totais foram obtidos por meio de refratômetro (Instrutherm $®$ ) (IAL, 2005), Os valores resultou-se em valores referentes à grama por $100 \mathrm{~g}$ do fruto do mesmo modo que a quantificação de açúcares e ácidos orgânicos, estes respectivamente foram realizados por Cromatografia Liquida de Alta Eficiência (HPLC), coluna 
Rezex ROA (300 x 7,8 nm). 0 B-caroteno e licopeno foram analisados por espectrofotômetro, conforme metodologia proposta por Rodriguez-Amaya (2004).

\section{RESULTADOS E DISCUSSÃO}

Os dados referentes ao tamanho, dimensões mínimas e máxima, densidade e peso do maná-cubiu estão expressos na Tabela 1.

Tabela 1 - Caracterização física do maná-cubiu $(n=25)$

\begin{tabular}{|c|c|}
\hline \multicolumn{1}{|c|}{ Parâmetros } & Valores médios* $^{*}$ \\
\hline Peso do fruto integral $(\mathrm{g})$ & $87,51 \pm 20,47$ \\
\hline Comprimento $(\mathrm{cm})$ & $5,49 \pm 0,20$ \\
\hline Diâmetro máximo $(\mathrm{cm})$ & $5,46 \pm 0,03$ \\
\hline Densidade $\left(\mathrm{g} / \mathrm{cm}^{3}\right)$ & 0,93 \\
\hline
\end{tabular}

NOTA: * Resultados expressos como média \pm Desvio Padrão (DP) $n=25$ frutas.

O peso dos frutos $(87,51 \pm 20,47)$ e os diâmetros $(5,46 \pm 0,03)$ provenientes da Mata Atlântica do litoral paranaense, foram menores do que os frutos de diversas variabilidades morfológicas e genéticas estudadas no estado do Amazonas (FILHO, 1999; LIMA, 2015). 0 maná-cubiu, possui 28 etnovariedades com dimensões (cilíndrico, redondo ou achatado) e fenótipos diferentes (FILHO et al., 2005). Os frutos cultivados no Paraná se apresentam no formato redondo, conforme mostra a Figura 1. Sendo que o manácubiu apresenta aparência física semelhante ao tomate (Solanum lycopersicum), fruto da mesma família.

0 comprimento médio do fruto é de $5,49 \mathrm{~cm}$ e diâmetro $5,46 \mathrm{~cm}$, valores aproximados ao estudo de Bezerra et al. (2018), em que o tomate apresentou comprimento e diâmetro $(6,16 \mathrm{~cm} \mathrm{e} \mathrm{4,37} \mathrm{cm}$ respectivamente), semelhante ao formato do maná-cubiu.

Figura 1 - maná-cubiu maduro

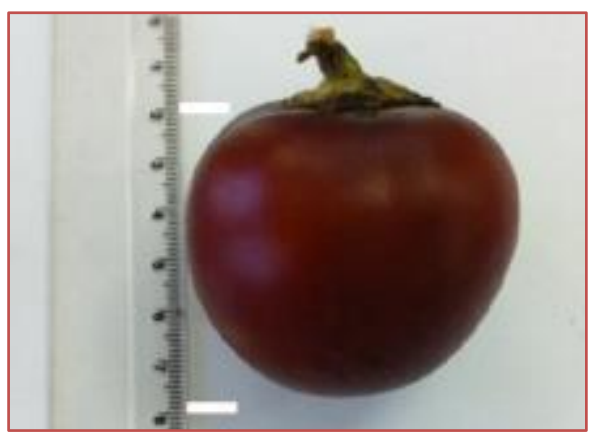

Fonte: Sereno et al., (2019).

Não foram encontrados estudos que calculassem o rendimento do maná-cubiu. Observaram-se perdas mínimas durante o corte dos frutos, sendo que seu rendimento, após a retirada da casca e do pedúnculo, (aproximadamente 12,11g) foi de 86\% em partes comestíveis e para a determinação da densidade de sólidos obteve-se $0,93 \mathrm{~g} / \mathrm{cm}^{3}$. 
Tabela 2 - Rendimento médio do maná-cubiu ( $\mathrm{n}=25)$

\begin{tabular}{|c|c|c|}
\hline Determinação & Massa média (g) & Rendimento (\%) \\
\hline Massa do fruto & $87,51 \pm 20,47$ & 100 \\
\hline Polpa & $75,39 \pm 19,58$ & 86,1 \\
\hline Casca total & $9,71 \pm 1,21$ & 11,0 \\
\hline Pedúnculo & $3,30 \pm 0,89$ & 3,7 \\
\hline
\end{tabular}

Em relação à determinação de carotenoides, o maná-cubiu pode ser considerado um alimento fonte em carotenoides, sendo esses compostos encontrados com predominância em vegetais vermelhos e/ou alaranjados. Para esse fruto, foram encontrados o licopeno e o $\beta$-caroteno nas concentrações de 3,36 $\mu \mathrm{g} / \mathrm{g} \pm 0,34$ e $11,26 \mu \mathrm{g} / \mathrm{g} \pm 0,15$ respectivamente, valores maiores quando comparados com o tomate (AMAYA, KIMURA e FARFAN, 2008). Os açúcares encontrados foram glicose (52\%) em maior concentração, frutose (38\%) e sacarose (10\%) e (Gráfico 1). Dos ácidos orgânicos, observou-se a presença de ácido cítrico a $0,62 \mathrm{mg} / \mathrm{mL}$, obtendo predominância do componente ácido sobre os açúcares, podendo explicar seu sabor, ligeiramente ácido.

\section{Gráfico 1- Composição de açúcares do maná-cubiu}

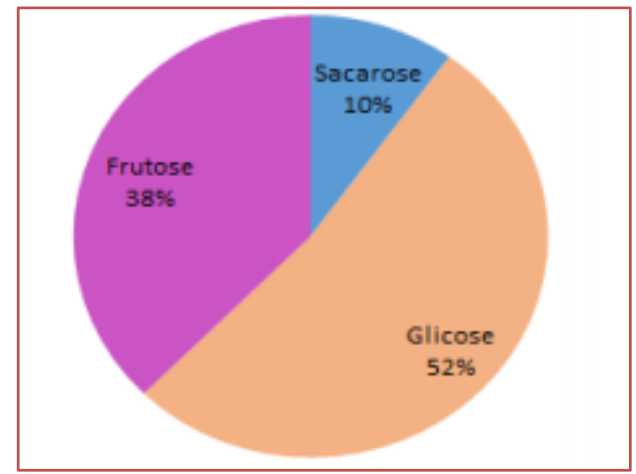

Quanto as demais composições nutricionais, o fruto apresentou teor de umidade de 90\%, próximo aos teores encontrados nos frutos da mesma família: pimentão (87,3\%) e tomate $(93,7 \%$ ) (AZOUBEL, GARCIA E NAVES, 1998). Os resultados para cinzas corroboraram com os estudos de Pires (2006) e Villachica (1996). O maná-cubiu apresentou alto teor de pH e acidez. Podendo ser indicado para formulação de sucos, devido à sua acidez aumentar o rendimento industrial. Outra opção de preparo está na produção de geleias, no qual encontra-se de acordo com o pH $(3,24 \% \pm 0,03)$ ideal recomendado pela Resolução da Comissão Nacional de Normas e Padrões para alimentos (BRASIL, 1978). E para o teor de sólidos solúveis (SST) foi obtido 5,33\% e acidez titulável 1,95\%.

Em relação à quantidade de macronutrientes, o teor de proteína encontra-se próximo ao tomate $(1,1 \mathrm{~g})$ (TACO, 2017), e os lipídios inferior aos teores encontrados em outros estudos (PIRES et al. 2006; VILLACHICA, 1996 e YUYAMA et al., 2007). As proteínas e lipídeos correspondem uma quantidade baixa, o que é comum em frutos. Entretanto, os carboidratos corresponderam 85\%, podendo ser atribuído por alto teor de fibras em sua composição. A ingestão de $100 \mathrm{~g}$ do maná-cubiu fruto fornece cerca de 3,72 g de fibras. De acordo com o Regulamento Técnico Brasileiro referente à Informação Nutricional Complementar, um alimento é considerado fonte de fibras quando possui no mínimo 3 g de fibra alimentar total (FAT/100g) (SERENO et al., 2018). Desta forma, o maná-cubiu pode ser considerado um fruto fonte de fibra alimentar (BRASIL, 1998). Algumas Distinções de caracterização do manácubiu encontrada no presente estudo podem estar associadas ao solo, o qual difere e interfere diretamente nas quantidades de nutrientes de uma planta (SALVADOR, CARVALHO e LUCCHES, 2011). 
Gráfico 2 - Caracterização físico-química do maná-cubiu

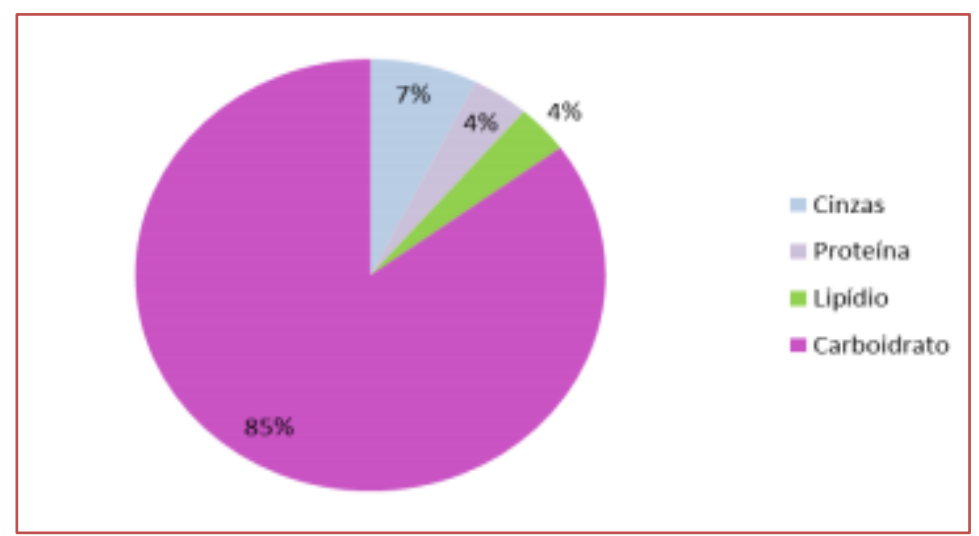

NOTA: Resultados expressos como média \pm Desvio Padrão (DP) de $100 \mathrm{~g}$ da fruta liofilizada.

\section{CONCLUSÃO}

O maná-cubiu coletado na Mata Atlântica do litoral paranaense é um fruto com teor de pH favorável para formação de géis, sendo indicado para formulação de sucos para fins industriais. Por apresentar pouca quantidade de açúcares, permite sua aplicação para o consumo de indivíduos diabéticos ou aqueles que necessitam compor uma dieta hipocalórica.

\section{REFERÊNCIAS}

[1] AMAYA, D.R.; KIMURA, M.; FARFAN, J.A. Fontes brasileiras de carotenoides. Tabela Brasileira de Composição de Carotenoides em Alimentos. Lidio Coradin e Vivian Beck Pombo, Organizadores. - Brasília: Ministério do Meio Ambiente. Secretaria de Biodiversidade e Florestas, 100, 2008.

[2] BARBOSA, L.E. “Cultivo do cubiu (Solanum sessiliflorum Dunal) sob o efeito de irrigação por gotejamento em ambiente protegido” (Dissertação de mestrado). Instituto Nacional de Estudos da Amazônia, Manaus, 2015.

[3] BEZERRA, C.S.; CASTRO, J.S., PADILHA, M.L.; ROMANO, C.; OTANI, F.S. CARACTERIZAÇÃO FÍSICO-QUÍMICA DE TOMATE ITALIANO PRODUZIDOS NA REGIÃO OESTE DO PARÁ. Agroecossistemas, v. 10, n. 2, p. 37 - 49, 2018.

[4] BOLDRINI, E.B., PAES, L.S. \& PINHEIRO, F. (2016). Clima: Boas práticas de adaptação. (1.ed.). Antonina: Ademadan. Brasil, Agência Nacional de Vigilância Sanitária.

[5] FILHO, D. F. F.YUYAMA, L. K. O, AGUIAR, J. P. L., OLIVEIRA, M.C. \& MARTINS, L.H.P. Characterization and evaluation of the agronomic and nutritional potential of ethnovarieties of cubiu (Solanum sessiliflorum Dunal) in Amazonia. Acta Amaz., 35 (4), 399 - 406, 2005.

[6] GILSON, G.J. Produtos \& Ingredientes. Os encantos do maná-cubiu, Bom Gourmet. Gazeta do povo. Disponível em http://www.gazetadopovo.com.br/bomgourmet/os-encantos-mana-cubiu/ Lima, E.B., 2015.

[7] Resolução da Comissão Nacional de Normas e Padrões para alimentos; Normativa n.o 9, 1978 (DOU de 11 dezembro de 1978). Ferreira, S.M.R (2002). Controle da qualidade em sistemas de alimentação Coletiva I (1.ed.). São Paulo: Livraria.

[8] VARElA. FILHO, D. F. S., ANDRADE, J. S., ClEMENT, C. R., MACHADO, F. M. \& NODA, H. “Correlações fenotípicas, genéticas e ambientais entre descritores morfológicos e químicos em frutos de cubiu (Solanum sessiliflorum Dunal) da amazônia," Acta Amazónica, 29 (4), 503-511, 1999.

[9] MAIA, J.R.P., SCHWERTZ, M.C., SOUZA, R.F.S, AGUIAR, J.P.I, LIMA, E.S. Efeito hipolipemiante da suplementação dietética com a farinha do cubiu (Solanum sessiliflorum Dunal) em ratos hipercolesterolêmicos, Revista Brasileira de Plantas Medicinais, Campinas, v.17, n.1, p.112-119, 2015.

[10] OLIVEIRA, H.P. Elaboração de nectar de cubíu (Solanum sessiflorum Dunal) e avaliação das características físico-químicas e sensoriais durante o armazenamento. 1999. 68 f. Tese (Doutorado)-Universidade do Amazonas, Manaus, 1999.

[11] SALVADOR, J.T., CARVALHO, T.C. \& LUCCHES, L.A.C. HarvestPlus handbook for carotenoid analysis. Cali: IFPRI: CIAT. 2011.

[12] SALVADOR, J.T.; CARVALHO, T.C.; LUCCHES, L.A.C. Relações cálcio e magnésio presentes no solo e teores foliares de macronutrientes. Revista Acadêmica: Ciências Agrárias e Ambientais, v. 9, n. 1, p. 27-32, 2011. 
[13] SEQUI, S.J.M. Androgenesis in Solanaceae. Methods in Molecular Biology, n. 1359, p. 209-44, 2016.

[14] SERENO, A.B., BAMPI, M., SANTOS, E., FERREIRA, S.M.R., BERTIN, R.L., KRÜGER, C.H. Mineral profile, carotenoids and composition of cocona (Solanum sessiliflorum Dunal), a wild Brazilian fruit. Journal of Food Composition and Analysis Volume 72, Pages 32-38, 2018.

[15] SOUZA, L.T. \& ZONTA, J. P. Caracterização física e química de cúbio (Solanum sessiliflorum Dunal) durante o seu desenvolvimento. Revista Ciência agronômica, 3 (8)., 2008.

[16] Tabela brasileira de composição de alimentos - TACO (4. a ed.). Campinas: UNICAMP/NEPA. (2017).

[17] VILlACHICA, H. Cocona (Solanum sessiliflorum Dunal). In: Villachica, H. Frutales y hortalizas promissórios del Amazonas. Lima: Secretaria Pro-Tempore (1996).

[18] YUYAMA, L.K.O. PEREIRA, Z. R. F., AGUIAR, J. P. L. SILVA, F. D. F., SOUZA, R. F. S. \& TEIXEIRA, A.P. Estudo da influência do cubiu (Solanum sessiliflorum Dunal) sobre a concentração sérica de glicose. Rev.Inst Adolfo Lutz, 64 (2), 232-236, 2005.

[19] YUYAMA, L.K.O. MACEDO, S.H.M. AGUIAR, J. P.L., FILHO, D. S.,YUYAMA, K., FÁVARO, D.I.T \& VASCONCELLOS, M.B.A. Quantificação de macro e micro nutrientes em algumas etnovariedades de cubiu (Solanum sessiliflorum Dunal). Acta Amazônica, 37 (3), 425-307, 2007. 


\title{
Capítulo 6
}

\section{Compostos bioativos presentes em abricó (Mammea americana), fruta da região amazônica brasileira}

\author{
Pollyane da Silva Port's \\ Wellington da Silva Oliveira \\ José Teixeira Filho \\ Helena Teixeira Godoy
}

Resumo: A América Tropical é considerada centro de origem de muitas árvores frutíferas, algumas das quais foram domesticadas ao longo do tempo pelos povos nativos. A sua riqueza se dá também pela situação geográfica, a heterogeneidade e a mistura de duas floras, a da América do Norte e a da Amazônia, as quais se estendem até as áreas baixas da América Central. 0 Brasil é um país com grande diversidade em espécies de frutas tropicais, no entanto ainda pouco exploradas, mas com um enorme potencial agroindustrial. Neste contexto a Mammea americana, conhecida popularmente como abricó, torna-se interessante para estudo, por apresentar dados escassos quanto à composição nutricional e funcional. Dentre os vários compostos funcionais presentes na fração lipídica, destacam-se os tocoferóis e ácidos graxos, principalmente pela sua atividade antioxidante. Neste estudo alguns compostos funcionais da fruta M. americana, obtida de dois estados brasileiros (Belém/PA e Manaus/AM) e de 2 acessos (Kamatá 1 e 2) fornecidos pela EMBRAPA-Amazônia foram avaliados. Foram analisados quatro dos isômeros da vitamina $\mathrm{E}$ (tocoferol) através da técnica de cromatografia líquida de alta eficiência (HPLC) com fase normal e um detector de fluorescência. 0 perfil dos ácidos graxos foi obtido através da cromatografia gasosa acoplada a um detector de ionização de chama (GC-FID) e a confirmação dos mesmos foi realizada por meio de cromatografia gasosa acoplada a espectrometria de massas, tipo quadrupolo, (CG-MS). Os resultados obtidos para os homólogos do tocoferol mostraram que apenas o alfa-tocoferol foi detectado na concentração de aproximadamente 1,1 $\mathrm{gg} \cdot \mathrm{g}-1$ para todas as amostras. A polpa de abricó apresentou os ácidos láurico, mirístico, palmítico, esteárico, lignocerico, palmitoleico, oleico, linoleico e linonênico, do total aproximadamente $60 \%$ são insaturados. Dentre os ácidos graxos encontrados as maiores parcelas foram atribuídas ao ácido palmitoleico (26\%), juntamente com o ácido oleico (20\%), o ácido linoleico (20\%) e o ácido linolênico (17\%). Os resultados obtidos são importantes para o levantamento de dados de frutas pouco conhecidas, provenientes da região amazônica brasileira. Além disso, os resultados mostraram que o abricó possui quantidade significativa de ácidos graxos e tocoferóis, compostos importantes na dieta.

Palavras-chave: Abricó, Vitamina E, ácidos graxos. 


\section{INTRODUÇÃO}

No Brasil, diversas espécies não-tradicionais vêm sendo utilizadas pelas populações locais, pelo grande potencial para exploração no mercado de consumo in natura e/ou industrializado. No entanto, são espécies que necessitam ser preservadas, cultivadas racionalmente e caracterizadas através do estudo de suas propriedades, visando sua utilização especialmente no mercado de alimentos funcionais. Além disso, existe uma demanda cada vez maior nos mercados interno e externo por novos sabores, cores e texturas (LORENZI et al., 2002).

A bacia amazônica é rica em recursos genéticos de frutas e oleaginosas, e sua exploração econômica é de grande importância para a região. As frutas, de um modo geral, desempenham um papel de grande destaque na dieta dos seres humanos pelos benefícios à saúde que proporcionam, traduzindo pela presença de nutrientes (vitaminas, minerais e fibras) e pela atividade que alguns desses nutrientes apresentam, levando ao aumento da expectativa de vida, vitalidade, prevenção de inúmeras doenças, e outras (LORENZI et al., 2006).

O aumento significativo, nos últimos anos, das enfermidades crônicas e degenerativas converteu-se em um dos principais problemas de saúde nos países desenvolvidos e em desenvolvimento. Isto tem aumentado o interesse da ciência em descobrir fatores preventivos destes processos. Neste sentido, estudos tem demonstrado que o consumo de frutas e verduras vem sendo apontado como fundamental na prevenção de enfermidades, devido à presença de diferentes compostos bioativos nesses alimentos. (COSTA \& ROSA, 2006).

Segundo a Sociedade Brasileira de Cardiologia (2004) os distúrbios cardiovasculares são responsáveis, no mundo, por um terço do total de mortes. No Brasil especificamente, estas doenças situam-se como a mais importante na causa de mortes. Essa alta incidência de doenças cardiovasculares é frequentemente correlacionada ao alto consumo de alimentos ricos em colesterol e gorduras saturadas, ao baixo consumo de fibras dietéticas e principalmente de biocompostos com capacidade antioxidante, tais como os compostos fenólicos (LIM et al., 2007).

Assim, o consumo de frutas tropicais está aumentando no mercado interno e nos mercados internacionais, devido ao crescente reconhecimento da sua função nutricional e funcional, além do seu valor terapêutico (RUFINO et al., 2010). Mas é importante salientar que apenas a identificação e a quantificação destes compostos não são parâmetros suficientes para avaliar o quanto um alimento ou um determinado composto é benéfico à saúde, uma vez que tais compostos nunca estão sozinhos e pode haver reações sinérgicas ou antagônicas entre eles. Assim, a verificação destas interações também é importante, bem como a verificação da capacidade antioxidante do alimento como um todo (IACOPINI et al., 2008).

Entre as frutas e oleaginosas extraídas na Amazônia, há espécies excepcionalmente ricas em micronutrientes, em particular antioxidantes, tais como tocoferóis, carotenoides, antocianinas e compostos polifenóis (ROSSO \& MERCADANTE, 2007).

O abricó (Mammea americana L.), pertencente à família da garcinia (Clusiaceae) é uma fruta originária das Índias Ocidentais e do norte da América do Sul, atualmente encontrada principalmente na Amazônia e algumas outras poucas regiões (CAVALCANTE, 1991). O abricoteiro foi introduzido na Amazônia Brasileira no início do século XIX, sendo inicialmente cultivado no então Jardim Botânico da capital da Província do Pará e utilizado na arborização de ruas. Os primeiros pomares comerciais de abricoteiro foram estabelecidos em meados da década de 1980, implantados com mudas oriundas de sementes, advindo desse fato, grande proporção de plantas do sexo masculino e expressivas variações fenotípicas. 0 fruto é muito popular no estado, sendo conhecido em outras regiões do Brasil como abricó-do-pará (CAVALCANTE, 1996).

Estudos desenvolvidos na Embrapa Amazônia Oriental evidenciaram que, na microrregião de Belém, a frutificação do abricoteiro ocorre de junho a dezembro (NASCIMENTO et al., 2008). Para a cidade de Manaus não foram encontrados, na literatura, estudos relacionados a época de floração e frutificação do abricó.

Por se tratar de uma fruta ainda silvestre, ou seja, a colheita ainda tem caráter extrativista, dados relacionados à sua produção e comercialização ainda são escassos, sabe-se porém que, depois da coleta os frutos são repassados para intermediários a um baixo custo e revendidos em mercados maiores a um valor mais elevado. No atual cenário, a demanda é pequena e destinada apenas aos consumidores locais (BRAGA et al., 2010). 
O abricó é um fruto grande, com 7-18 cm de diâmetro podendo chegar ao peso de até $1 \mathrm{Kg}$, coberto com uma casca rugosa e resistente de cor pardo-alaranjada, contém uma polpa de coloração alaranjada intensa e brilhante, de um agradável sabor e aroma perfumado. 0 fruto é consumido in natura e também usado para produção de conservas, doces e pastas. Suas sementes (1-4) são grandes, amargas e resinosas e são utilizadas como um agente vermífugo (MORALES \& DUQUE, 2002).

Tanto os ácidos graxos monoinsaturados e poli-insaturados, quanto os componentes lipídicos menores, tais como tocoferóis e fitosteróis, desempenham um papel importante na nutrição humana e saúde. Esses compostos têm despertado interesse e preocupação, principalmente nesta última década, uma vez que compõe juntamente com a vitamina $C, \beta$-caroteno, selênio e flavonoides, o grupo denominado antioxidantes alimentares. Este grupo também tem sido frequentemente associado à prevenção de doenças neurodegenerativas, aterosclerose, inflamação crônica, câncer e envelhecimento precoce (D0 et al., 2015; GUINAZI et al., 2009; TURAN et al., 2007; ATTAR-BASHI, et al., 2004; GROOTVELD, et al., 2001).

A vitamina $E$, termo genérico utilizado para designar diferentes compostos, nomeados $\alpha-, \beta-, \gamma$ - e $\delta$ - (alfa, beta, gama e delta) tocoferóis (T) e $\alpha-, \beta-, \gamma_{-}^{-}, \delta$-tocotrienol (T3) (GUINAZI et al., 2009), tem sido extensivamente estudada em diversas áreas do conhecimento. Dentre os tocoferóis, especialmente $\alpha$ - e $\gamma$ tocoferol, são particularmente os mais abundantes (BRAUNRATH et al., 2010). Os tocoferóis desempenham papéis especialmente importantes na reprodução e em mecanismos antioxidantes de tecidos animais e vegetais. Poucos trabalhos têm pesquisado a composição completa dos isômeros da vitamina E em alimentos, sendo que a maioria tem relatado apenas o conteúdo do $\alpha$-tocoferol, já que este é apontado como sendo o mais potente em sua ação antioxidante. No entanto, alguns trabalhos indicam que outros isômeros como $\gamma$ - e $\delta$-tocoferol são melhores antioxidantes que o $\alpha$-tocoferol (CHAUVEAUDURIOT et al., 2010; GUINAZI et al., 2009; WAGNER \& ELMADFA, 2000). Essas controvérsias, em relação a qual isômero possui maior ação antioxidante, podem ocorrer devido a diferenças entre os métodos testados, os substratos utilizados, o nível de oxidação empregado e as metodologias empregadas para monitoramento da oxidação. Por isso, métodos confiáveis e sensíveis são essenciais para a determinação da ação antioxidante dos tocoferóis presentes em alimentos (CHAUVEAU-DURIOT et al., 2010; GUINAZI et al., 2009; MEHMOOD, 2015). Além disso, as tabelas brasileiras de composição de Alimentos ainda não contemplam os diferentes isômeros da vitamina $\mathrm{E}$, o que torna importante as pesquisas envolvendo a composição completa em alimentos brasileiros (GUINAZI et al., 2009).

A fração lipídica da polpa do abricó provê outros nutrientes essenciais, os ácidos graxos. Estes podem ser classificados em dois grupos, saturados e insaturados, estes últimos com um papel importante na regulação de vários processos metabólicos, com funções especiais no equilíbrio homeostático, e em componente estrutural das membranas celulares e do tecido cerebral e nervoso (AQUINO et al., 2012; FOSTER \& WILLIAMSON, 2009; ATTAR-BASHI, et al., 2004). A carência de ácidos graxos na alimentação dos mamíferos (especialmente do homem) conduz a alterações no crescimento, na pele, imunológicas, neurológicas, e sérios transtornos comportamentais.

Diversas técnicas têm sido aplicadas para separação e quantificação de tocoferóis e ácidos graxos nas mais variadas matrizes orgânicas e podem ser utilizadas de acordo com os objetivos da análise e da natureza da amostra. Entretanto, a cromatografia líquida com detecção por fluorescência para tocoferóis e a gasosa acoplada ao detector de ionização de chama para os ácidos graxos tem sido extensivamente aplicadas e são preferidas pela grande maioria dos pesquisadores da área (PINHEIRO-SANT'ANA et al., 2011; FARKAS et al., 2008; VISENTAINER \& FRANCO, 2006).

Por isso se faz importante investigar a composição lipídica de novas fontes de nutrientes e compostos bioativos para a dieta, já que estudos no que diz respeito à composição química lipídica do abricó ainda não existem. Assim, este trabalho teve como objetivo avaliar a composição dos isômeros de tocoferol, assim com obter a composição dos ácidos graxos presentes na polpa do abricó, que é uma fruta ainda pouco explorada.

\section{MATERIAL E MÉTODOS}

\subsection{AMOSTRAS}

As frutas provenientes de acessos (Kamatá 1 e Kamatá 2), utilizadas neste trabalho foram fornecidas pela Embrapa Amazônia Oriental, Belém/Pará, in natura em um único lote para cada um dos acessos. As demais foram obtidas no comércio local de Belém/PA e em Manaus/AM, em três lotes obtidos nos anos de 2011, 2012 e 2013. Para cada lote foram adquiridos 3 a 4 frutos, especificamente no mês de julho de cada ano. 
Os frutos foram descascados, cortados e levados para liofilização. As amostras após serem liofilizadas foram então moídas e acondicionadas em sacos metálicos (ao abrigo de luz) e seladas a vácuo (livres de 02) e posteriormente refrigeradas, até o momento da análise.

\subsection{REAGENTES E SOLVENTES}

Para a preparação das amostras, foram utilizados os seguintes reagentes de qualidade analítica: acetato de etila, hexano e isopropanol (Synth, Brasil), sulfato de sódio (Vetec, Brasil), e butil-hidroxitolueno (BHT) (Synth, Brasil). Os padrões utilizados ( $\alpha$-, $\beta-, \gamma$ - e $\delta$-tocoferóis) foram adquiridos a partir de Calbiochem ${ }^{\circledR}$, EMD Biosciences, Inc. (EUA) e armazenados a $-18^{\circ} \mathrm{C}$ até a utilização. Os padrões de ésteres metílicos do C4 ao C24 (FAME Mix) foram adquiridos da Supelco (EUA).

As fases móveis foram preparadas utilizando reagentes de grau HPLC: hexano e isopropanol (Mallinckrodt, EUA) e ácido acético (Merck, Brasil). As soluções de estoque padrão de tocoferol foram preparadas por dissolução em hexano de grau HPLC contendo 0,01\% de BHT nas concentrações de 100 mg.L-1. A solução-mãe padrão de ésteres metílicos de ácidos graxos foi preparada em hexano grau HPLC. Soluções de reserva dos padrões foram filtrados em filtro Millipore de 0,45 $\mu \mathrm{m}$ (PVDF - Millipore, EUA), armazenada a $-18^{\circ} \mathrm{C}$ e protegidas da luz. Os frascos contendo as soluções de trabalho foram colocados em ultrassons durante 5 min antes da injeção.

A filtração das amostras incluiu o uso de papel de filtro Whatman n¹ (J. Prolab, Brasil), seringas de $3 \mathrm{ml}$ estéreis (Rymco, Colômbia), e unidades de filtro de polietileno Millex HV (Millipore, 0,22 $\mu \mathrm{m}$, Brasil).

\section{MÉTODOS}

\subsubsection{EXTRAÇÃO DE LIPÍDIOS POR BLIGH-DYER}

Um dos procedimentos de extração mais versáteis e efetivos, é a metodologia de Bligh \& Dyer (1959), uma versão simplificada do procedimento clássico usando clorofórmio-metanol proposto por Folch et al. (1957). Para extração foram pesadas aproximadamente $1 \mathrm{~g}$ de amostra em tubos de ensaio com tampa. Em seguida foram adicionados $5 \mathrm{~mL}$ de clorofórmio, $10 \mathrm{~mL}$ de metanol e $4 \mathrm{~mL}$ de água, tornando a proporção 1:2:0,8, respectivamente. Os tubos foram agitados por 15 minutos e logo em seguida, foram adicionados mais $5 \mathrm{~mL}$ de clorofórmio e $5 \mathrm{~mL}$ sulfato de sódio (1,5\%). Os tubos foram então agitados novamente por mais 2 minutos e centrifugados a $3000 \mathrm{~g}-1$ por 5 minutos. 0 sobrenadante foi descartado e a fase inferior foi filtrada em papel Whatman $\mathrm{n}$ - 1, com aproximadamente $1 \mathrm{~g}$ de Na2SO4 anidro. 0 filtrado foi evaporado até a secura com $\mathrm{N} 2$ e armazenado a $-18 \stackrel{\circ}{ } \mathrm{C}$ até o momento da análise.

\subsubsection{DETERMINAÇÃO DOS TOCOFERÓIS}

Para a análise de tocoferóis, utilizou-se a metodologia empregada por Pinheiro-Sant'anna et al. (2011), com pequenas adaptações. Os extratos obtidos por Bligh-Dyer, foram diluídos em hexano na concentração

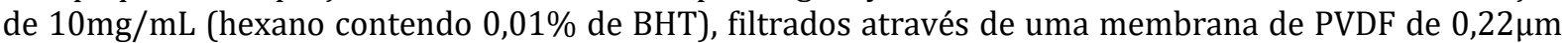
(Millipore, USA), e imediatamente injetados no sistema de cromatografia líquida de alta eficiência.

As análises dos tocoferóis foram realizadas utilizando um cromatógrafo à líquido de alta eficiência (HPLC) Agilent 1100 (Agilent Technologies, Alemanha) acoplado a um detector de fluorescência, sistema de bomba quaternária, injetor automático e forno para controlar a temperatura da coluna. As condições cromatográficas do método foram realizadas de acordo com os trabalhos de Souza et al. (2015), Górnas (2015); Ballus et al. (2014) e Pinheiro-Sant'ana et al. (2011). Foi utilizada uma coluna com dimensões de $150 \mathrm{~mm} \times 4,6 \mathrm{~mm} \times 3,0 \mu \mathrm{m}$ de fase normal (sílica Hypersil, Thermo, Alemanha) foi utilizada. A fase móvel consistiu de um sistema isocrático composto de hexano: isopropanol: ácido acético $(98,9: 0,6: 0,5)$ com um fluxo de $1,0 \mathrm{~mL}$ min-1 A temperatura foi mantida a $30^{\circ} \mathrm{C}$, e o volume de injeção foi de $100 \mu \mathrm{L}$. A detecção da fluorescência foi realizada em $\lambda \operatorname{Ex} 290 \mathrm{~nm}$ e $\lambda \operatorname{Em} 330 \mathrm{~nm}$. Os compostos foram identificados por comparação dos tempos de retenção dos compostos encontrados nas amostras com o padrão dos homólogos do tocoferol separados sob as mesmas condições bem como por co-cromatografia e a quantificação foi realizada através de uma curva padrão (padronização externa) contendo 10 pontos com concentração entre 10 e $55 \mathrm{ng} . \mu \mathrm{L}-1$. Todas as amostras foram injetadas em triplicata. 


\subsubsection{DETERMINAÇÃO DOS ÁCIDOS GRAXOS CG-FID E CONFIRMAÇÃO DA IDENTIDADE DOS ÉSTERES METÍLICOS POR CG/MS}

Para a análise dos ésteres metílicos foi utilizado o método proposto por Joseph \& Ackman (1992) com pequenas modificações, onde o extrato obtido por Bligh-Dyer, foi pesado em tubos com tampa e resuspendidos em $4 \mathrm{~mL}$ de $\mathrm{NaOH}$ 0,5 mol L-1 em solução com metanol. Os tubos foram levados para aquecimento em banho a uma temperatura de aproximadamente $100 \stackrel{\circ}{\circ} \mathrm{C}$ por 10 minutos. Posteriormente, foram adicionados aos tubos, $3 \mathrm{~mL}$ de trifluoreto de boro (BF3 - 12\% em solução com metanol) e levados novamente para serem aquecidos por mais 5 minutos. Depois de resfriados à temperatura ambiente, $4 \mathrm{~mL}$ de uma solução saturada de $\mathrm{NaCl}$ foi adicionada no tubo sob agitação. Logo em seguida, $4 \mathrm{~mL}$ de hexano foi adicionado e toda a mistura foi submetida a agitação vigorosa em vórtex. Os tubos ficaram em repouso até a separação das fases. A fase superior foi recolhida e o resíduo foi lavado com $2 \mathrm{~mL}$ de hexano por 3 vezes. As fases recolhidas foram então combinadas e concentradas até a secura em evaporador rotativo e ressuspendida novamente em $2 \mathrm{~mL}$ de hexano. 0 extrato foi armazenado a $-18{ }^{\circ} \mathrm{C}$ até o momento da análise. Todo o experimento foi preparado em triplicata $(n=3)$.

Para as análises cromatográficas utilizou-se o método de Ballus et al. (2014). Foi utilizado um cromatógrafo de gás modelo 7890 (Agilent, Alemanha) equipado com uma coluna capilar de sílica fundida com 50\% de cianopropil metil polisiloxano modificado (60 $\mathrm{m}$ de comprimento, $0,25 \mathrm{~mm}$ de diâmetro interno, 0,25 mm de espessura de filme) (Part number: 122-2362, Agilent, Alemanha), um detector de ionização de chama (FID) e um injetor tipo spli/splitless, com razão de split 1:25. Os parâmetros utilizados para determinação foram temperatura do injetor $\left(250^{\circ} \mathrm{C}\right)$, temperatura do detector $\left(280{ }^{\circ} \mathrm{C}\right), \mathrm{H} 2$ como gás de arraste com taxa de fluxo de 1,0 mL min-1, e no detector (H2:N2:ar sintético - 30:30:300 mL.min1). A rampa de temperatura foi iniciada com $50{ }^{\circ} \mathrm{C}$ passando para $17{ }^{\circ}{ }^{\circ} \mathrm{C}$ com taxa de ajuste de $25^{\circ} \mathrm{C} / \mathrm{min}$, posteriormente aumentada para $230{ }^{\circ} \mathrm{C}$ a uma taxa de ajuste de $4 \stackrel{\circ}{\circ} \mathrm{C} / \mathrm{min}$, totalizando assim 35,5 minutos de corrida A identificação dos picos foi feita por comparação dos tempos de retenção dos padrões, obtidos nas mesmas condições, e os tempos de retenção dos picos observados para as amostras. Os resultados da área são expressos em porcentagem de área total, ou seja, área do pico de um determinado ácido graxo em relação à área total (somatório da área de todos os picos de ácidos graxos). As amostras foram injetadas todas em triplicata.

A identificação dos ésteres metílicos de ácidos graxos foi realizada em cromatógrafo gasoso (CG) 7890A (Agilent, Alemanaha) acoplado a um detector de massas (MS) tipo quadrupolo. Para separação dos ésteres, utilizou-se uma coluna HP-5 (Aginet, Alemanha) de 30 metros de comprimento x 0,32 mm de diâmetro e fase estacionária de $0,50 \mu \mathrm{m}$ de revestimento. Os ésteres $(1 \mu \mathrm{L})$ foram injetados em modo split (1:25). 0 fluxo do gás de arraste (He) foi ajustado para $0,5 \mathrm{~mL} / \mathrm{min}$, a temperatura do injetor foi de $250^{\circ} \mathrm{C}$, a temperatura inicial do forno foi de $50{ }^{\circ} \mathrm{C}$ aquecendo a uma taxa de $1{ }^{\circ} \mathrm{C} / \mathrm{min}$ até atingir a temperatura de $110 \stackrel{\circ}{\circ}$ em seguida aumentou-se a taxa para $3 \stackrel{\circ}{\circ} \mathrm{C} /$ min até atingir uma temperatura de $310{ }^{\circ} \mathrm{C}$ onde permaneceu por mais 3 minutos, totalizando uma corrida de 129,67 minutos.

O fluxo de saída da coluna do CG para o espectrômetro de massas foi ajustado para uma temperatura de $250{ }^{\circ} \mathrm{C}$. A fonte de ionização por impacto de elétrons (EI) do MS foi ajustado para $70 \mathrm{eV}$ a uma temperatura de $200{ }^{\circ} \mathrm{C}$. 0 quadrupolo foi operado a uma temperatura de $150{ }^{\circ} \mathrm{C}$ no modo scan, com intervalo de monitoramento entre 50 e $500 \mathrm{~m} / \mathrm{z}$. Os dados foram obtidos através de um software ChemStation ${ }^{\circledR}$ (USA) utilizado para aquisição e processamento de dados. A identificação dos ésteres metílicos de ácidos graxos foi realizada por tentativa em comparação com os espectros da biblioteca virtual NIST ${ }^{\circledR}$ (versão 2011) e de forma positiva por comparação de espectros das amostras com os dos padrões analíticos injetados.

\subsubsection{ANÁLISE ESTATÍSTICA}

O tratamento estatístico dos dados foi realizado através da Análise de Variância (ANOVA), e as médias foram comparadas pelo teste de Tukey ao nível de $95 \%$ de confiança. Todas as análises estatísticas foram realizadas no software Statistica 7.0 (Statsoft, USA). 


\section{RESULTADOS E DISCUSSÃO}

\subsection{COMPOSIÇÃO DE ÁCIDOS GRAXOS}

Na Figura 1 tem-se o perfil cromatográfico obtido para uma das amostras de abricó proveniente de Belém. As amostras da polpa de abricó não apresentaram diferenças representativas quanto perfil cromatográfico dos principais ésteres metílicos.

0 perfil dos ácidos graxos, presentes nas polpas do abricó, identificados pelo método do CG-FID, estão apresentados na Tabela 1.

Figura 1. Cromatograma da composição de ácidos graxos por CG-FID para uma das amostras de Belém (B1). As condições cromatográficas estão descritas no texto. Os números identificam os ácidos graxos correspondentes à Tabela 1.

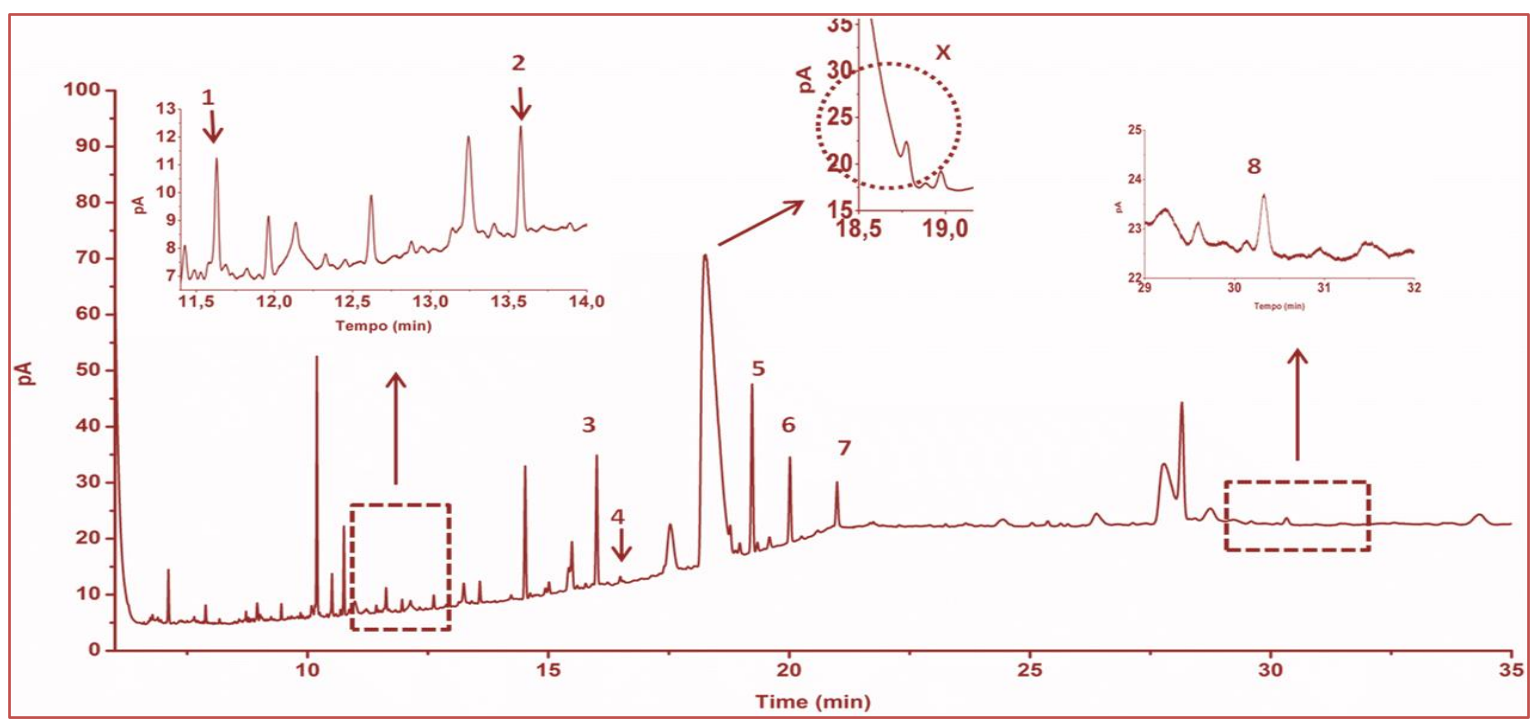

Tabela 1. Teores de ácidos graxos obtidos da polpa de abricó (média \pm desvio padrão, $\mathrm{n}=3$ )

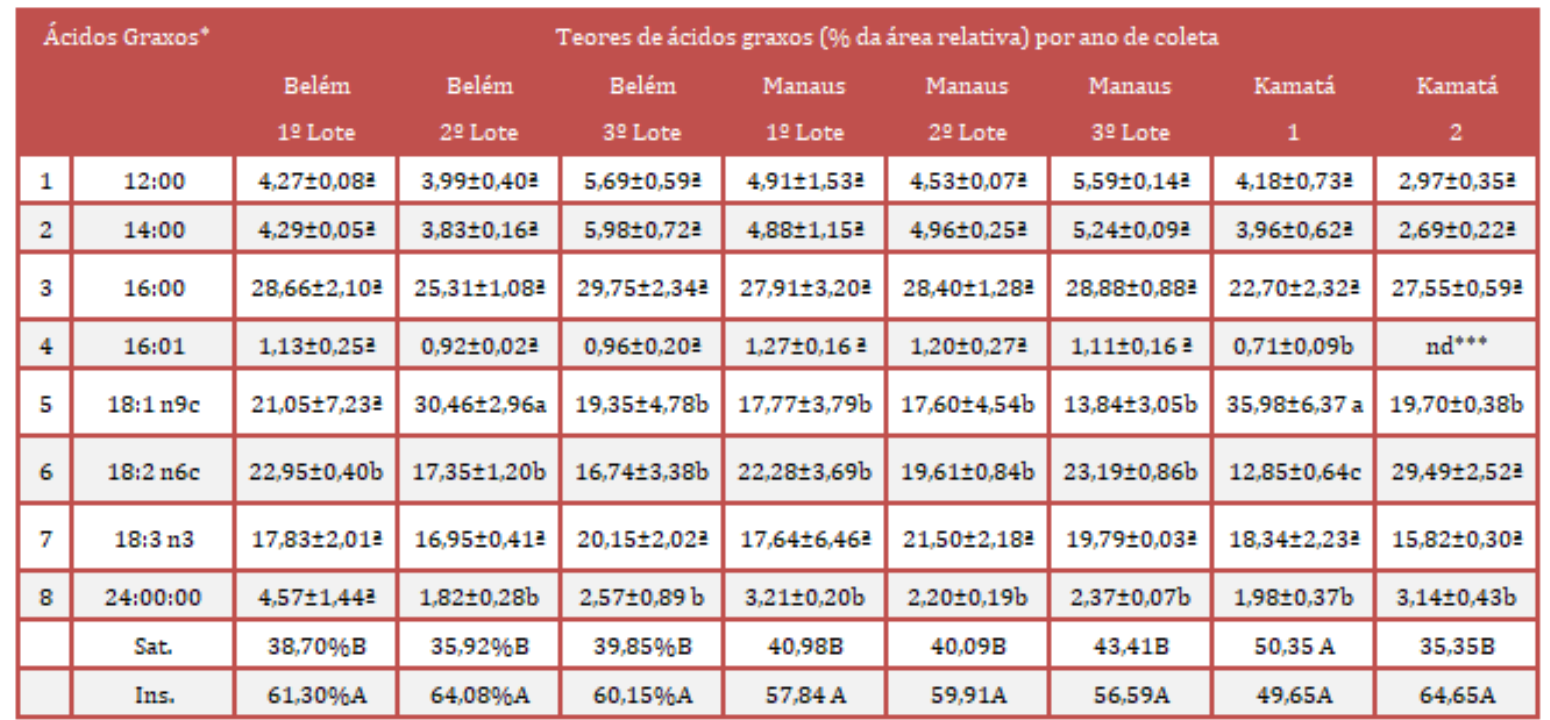

*nomenclatura de ácidos graxos: 12:0, ácido láurico 14:0, ácido mirístico 16:0, ácido palmítico; 16:1, ácido palmitoléico; 18:1n-9, ácido oleico; 18:2n-6, ácido linoleico; 18:3n-3, ácido $\alpha$-linolênico; 24:0, ácido lignocérico. **Diferenças significativas na mesma coluna são indicadas com letras maiúscula diferentes. Diferenças significativas na mesma linha são indicadas com letras minúsculas diferentes (A - B) 
Dentre os compostos encontrados na polpa do abricó (Tabela 1) estão o ácido láurico (C12:0), ácido mirístico (C14:0), ácido palmítico (C16:0), ácido palmitoléico (C16:1), ácido oléico (C18:1n9cis), ácido linoléico (C18:2-cis), ácido linolênico (C18:3n-6cis) e o ácido lignocérico (C24:0). Apenas para o lote K2 não foi detectado o C16:1, provavelmente pela baixa concentração deste composto.

0 perfil dos ésteres metílicos do abricó avaliado neste trabalho apresentou os ácidos graxos insaturados oleico, linoleico e linolênico (C18:1 - 20\%, C18:2 - 20\% e C18:3 - 18,5\%), seguido pelo ácido palmítico (C16:0 - 26\%). Para todos os lotes das diferentes localidades apresentaram prevalência de ácidos graxos insaturados, sendo a porcentagem encontrada no 3o lote de Belém juntamente com o Kamatá 2 (64\%), o que é considerado uma característica positiva do ponto de vista nutricional. Os óleos da polpa apresentaram elevados teores de ácido linolênico ou ômega-3 (C18:3) (18,5\%), considerado ácido graxo essencial à alimentação humana. Este ácido graxo possui efeito hipocolesterolêmico, considerado útil na redução do risco de várias doenças e poderá ser consumido na forma in natura, o que é uma vantagem nutricional, posto que este ácido graxo é altamente insaturado e suscetível à oxidação pelo aquecimento.

O ácido esteárico (C18:0) também foi encontrado para algumas das amostras, entretanto, como a resolução não foi adequada, na maioria dos casos não foi quantificado, em termos de porcentagem, como pode visto no cromatograma da amostra B1 (Fig. 1) no tempo de 19 min aproximadamente (composto X).

As amostras, como mostra a tabela 1, não apresentaram diferença significativa para os ésteres metílicos de ácidos graxos, e as poucas variações ocorridas, podem ser consideradas resultantes de variabilidade natural para a espécie, principalmente por se tratar de uma espécie nativa.

Também pode ser observado dos resultados obtidos na Tabela 1 que não houve variações significativas $(\mathrm{p}<0,05)$ entre as proporções de ácidos graxos saturados e insaturados na polpa de abricó, em relação ao local e lotes. Nota-se que a fração insaturada foi significativamente maior que a quantidade de ácidos graxos insaturados que ficaram em torno dos 60 \%. Em comparação com a parcela saturada.

Dados relacionados à composição de ácidos graxos presentes no óleo da polpa de abricó não foram encontrados. Porém, outros trabalhos, como o de Wycoff et al. (2015), que encontraram nas polpas de outras frutas regionais tais como açaí roxo e branco, valores de $12,7 \% ; 7,8 \% ; 4,1 \%$ para açaí roxo e para o açaí branco valores de 26,7\%; 6,6\%; 4,6\% para os C16:1+C18:1, C18:2 e C18:3 respectivamente. Valores estes próximos aos encontrados para a polpa de abricó. Lopes et al. (2012), também encontraram em polpas de frutas do nordeste (araticum e pequi) além de outros compostos o C12:0, C14:0, C16:0, C16:1, C18:1, C18:2, C18:3, assim como neste presente trabalho. Coimbra (2012) analisou o óleo de polpa de guariroba, jerivá e macaúba e encontrou o C12:0, C14:0, C16:0, nas mesmas proporções, entre si, aos encontrados no respectivo trabalho.

Lutterod et al. (2011), afirmam que a qualidade do óleo está diretamente relacionado à predominância de ácidos graxos insaturados, uma vez que o grau de saturação está relacionado à depreciação do produto e o consumo de óleo com alto grau de saturação está diretamente ligado ao aparecimento de doenças no ser humano. 0 ácido linolênico, principalmente, é um dos ácidos graxos polinsaturados mais importantes na dieta alimentar. Os estudos realizados para se determinar a importância do metabolismo deste ácido graxo no corpo humano sugere que ele tem importância vital na prevenção de doenças como formação de prostaglandinas e eicosanoides, necessários na liberação hormonal das glândulas do hipotálamo e da tireoide, principalmente (BROUWER, et al., 2006).

Foi realizado em seguida a análise de GC-MS dos ésteres metílicos dos ácidos graxos, presentes na polpa de abricó anteriormente detectados e quantificados no GC-FID. Verificou-se que o composto que encontrava-se em baixa concentração não pode ser confirmado, isto ocorreu devido o GC-MS ter sido operado no modo scan fazendo com que a sensibilidade do equipamento tenha diminuído sensivelmente. Por isso apenas o 16:1 não foi confirmado.

Para os demais compostos todos foram confirmados. Na análise por CG-MS também pode ser confirmado à presença do esteárico, composto este que não pode ser quantificado pelo FID devido o mesmo estar coeluido com um interferente.

\subsection{COMPOSIÇÃO DE TOCOFERÓIS}

Dados relacionados à composição dos homólogos da vitamina E, na polpa de abricó, não foram encontrados na literatura. A Figura 2 apresenta um perfil cromatográfico obtido para a mistura da solução-padrão dos quatro isômeros da vitamina E estudados. A eluição dos compostos seguiu a ordem 
característica e já bem estabelecida pela literatura para análises utilizando sistema de fase normal: $\alpha$ tocoferol, $\beta$ - tocoferol, $\gamma$-tocoferol e $\delta$ - tocoferol.

Figura 2. Cromatogramas da mistura de padrões de tocoferóis (A) e uma das amostra da polpa de abricó (B). As condições cromatográficas estão descritas no texto.

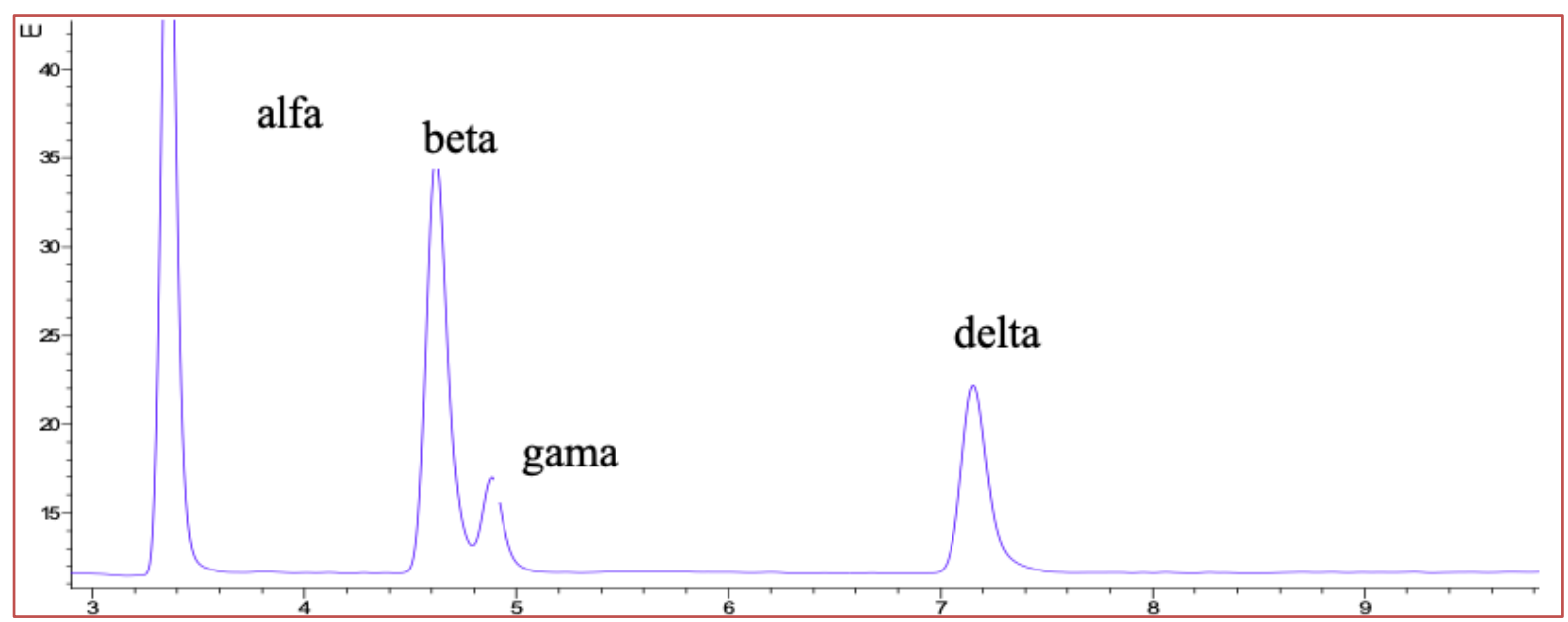

(a)

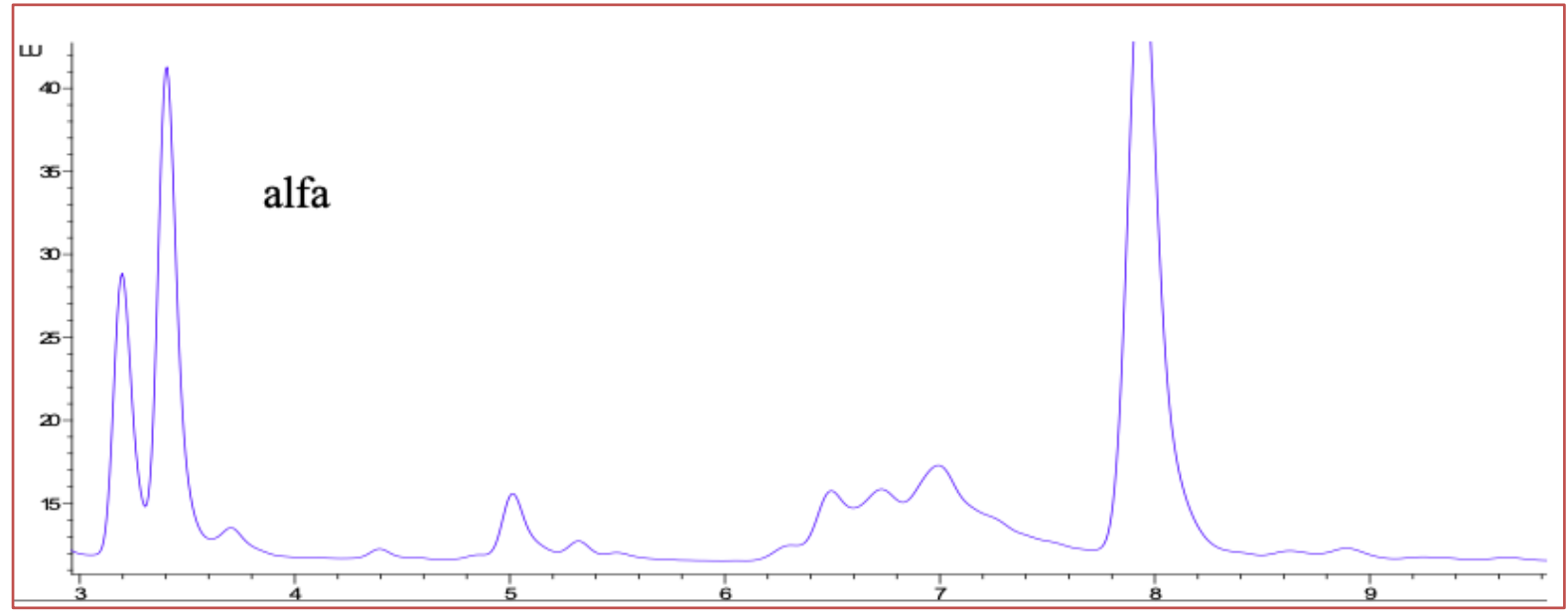

(b)

De todos os isômeros estudados da vitamina E, apenas o $\alpha$-tocoferol foi encontrado na polpa. A concentração do $\alpha$-tocoferol nas amostras de abricó analisados, estão apresentada na Tabela 2.

Relevante para essa observação em relação a presença do $\alpha$-tocoferol é o fato de ele também ser conhecido por estar concentrado principalmente em tecidos que metabolizam ativamente (por exemplo, nas célula cloroplastos), ao passo que os outros tocoferóis são mais encontrados em tecidos dormentes, como em óleos de sementes (KAMAL-ELDIN \& ANDERSSON 1997). 
Tabela 2. Concentração de $\alpha$-tocoferol presente na polpa liofilizada do abricó

\begin{tabular}{|c|c|c|}
\hline Amostras & $\begin{array}{c}\text { Teor de alfa tocoferol } \\
(\mu g . g-1 \text { de óleo)* }\end{array}$ & $\begin{array}{c}\text { Teor de alfa tocoferol }(\mu \mathrm{g} / 100 \mathrm{~g} \text { de } \\
\text { fruta)** }\end{array}$ \\
\hline B1 $(2011)$ & $0,76 \pm 0,11^{\underline{a}}$ & $1,52 \pm 0,33^{\underline{a}}$ \\
\hline B2 $(2012)$ & $1,05 \pm 0,05^{\underline{a}}$ & $2,11 \pm 0,10^{\underline{a}}$ \\
\hline B3 $(2013)$ & $1,18 \pm 0,10^{\underline{a}}$ & $2,37 \pm 0,20^{\underline{a}}$ \\
\hline M1 $(2011)$ & $1,04 \pm 0,13^{\underline{a}}$ & $2,09 \pm 0,25^{\underline{a}}$ \\
\hline M2 $(2012)$ & $0,86 \pm 0,08^{\underline{a}}$ & $1,73 \pm 0,16^{\underline{a}}$ \\
\hline M3 (2013) & $1,23 \pm 0,11^{\underline{a}}$ & $2,47 \pm 0,23^{\underline{a}}$ \\
\hline K1 $(2012)$ & $0,84 \pm 0,05^{\underline{a}}$ & $1,67 \pm 0,10^{\underline{a}}$ \\
\hline K2 $(2012)$ & $1,23 \pm 0,11^{\underline{a}}$ & $2,47 \pm 0,23^{\underline{a}}$ \\
\hline
\end{tabular}

*Valores representam a média de triplicata \pm o desvio padrão, seguidas de letras diferentes, minúsculas na coluna, diferem estatisticamente entre si pelo teste de Tukey a $5 \%$ de probabilidade.

**Valores dados em fruta liofilizada

Nota-se, através dos dados, que concentração do $\alpha$-tocoferol da vitamina E presente na polpa de abricó não diferiu estatisticamente $(\mathrm{p}>0,05)$ em relação ao local de procedência dos frutos bem como entre os lotes da mesma localidade, variando de 1,52 até $2,47 \mu \mathrm{g} / 100 \mathrm{~g}$ de fruta liofilizada. Esses resultados mostraram que, tanto a concentração como a composição, não mudaram em relação à localidade e épocas de colheita dos frutos.

Vilela et al. 2013, estudaram em 12 cultivares de manga (polpa) a presença dos isômeros da vitamina E, e o $\alpha$-tocoferol também foi o único detectado em todas as amostras de manga estudadas.

Charoensiri et al. (2009), encontraram em uma grande variedades de frutas frescas, totalizando 37 tipos, resultados de alfa tocoferol que variaram desde não detectável até $1,43 \mathrm{mg} / 100 \mathrm{~g}$, sendo que os maiores valores foram encontrados no durião (variedade "chanee") e na manga verde (variedade 'kheosawoei').

Kamal-Eldin \& Andersson (1997), realizaram um estudo estatístico utilizando uma técnica multivariada de análise de componentes principais (PCA) tentando estabelecer se havia qualquer correlação bioquímica entre conteúdo de tocoferol e percentuais de ácidos graxos em 14 óleos vegetais e viu que existia uma alta correlação entre os ácidos graxos insaturados, especificamente 18:1 e 18:2, com a presença do $\alpha$-tocoferol. Entretanto, os autores afirmam que outros fatores além do grau de insaturação, também podem influenciar nos níveis de tocoferol, tais como a natureza dos lipídios, a estrutura dos lipídios na presença de anti e/ou pró oxidantes, além de outros fatores como a quantidade de clorofila e/ou outros pigmentos, fotossensibilizadores que podem está presentes no óleo.

\section{CONCLUSÃO}

A análise de ácidos graxos no abricó mostrou que existem quantidades significativas de ácidos graxos insaturados (cerca de 60\%). Com relação aos resultados obtidos para os tocoferóis presentes na polpa do abricó, estes se mostraram importantes, já que os valores encontrados na polpa mostraram quantidades interessantes de $\alpha$-tocoferol, quando comparadas a outras frutas exóticas, contribuindo para o consumo da vitamina E, levando em consideração o índice de ingestão diária que é de $10 \mathrm{mg}$ de $\alpha$-tocoferol/dia. Os resultados deste estudo representam uma grande contribuição para a caracterização do abricó, uma vez que trabalhos desta natureza são escassos para a respectiva fruta e outras ainda pouco conhecidas da região amazônica, resultados estes que permitem refletir com maior veracidade os nutrientes consumidos por essa população. 


\section{REFERÊNCIAS}

[1] AQUINO, J.D.E.; PESSOA, D.C.N.D.P.; ARAÚJO, K.D.L.G.V.; EPAMINONDAS, P.S.; SCHULER, A.R.P.; SOUZA, A.G.D.; STAMFORD, T.L.M. Refining of Buriti Oil (Mauritia flexuosa) Originated from the Brazilian Cerrado: Physicochemical, Thermal-Oxidative and Nutritional Implications. Journal Of The Brazilian Chemical Society, Vol. 23, No. 2, 212-219, 2012.

[2] ATTAR-BASHI, N.M.; FRAUMAN A.G.; SINCLAIR, A.J., Alpha-linolenic acid and the risk of prostate cancer. What is the evidence? The Journal of Urology. 171, 2004.

[3] BALlUS, C.A.; MEINHART, A.D. CAMPOS JR., F.A. de S.; SILVA, L.F. de O. da; OLIVEIRA, A.F. GODOY, H.T. A quantitative study on the phenolic compound, tocopherol and fatty acid contents of monovarietal virgin olive oils produced in the southeast region of Brazil. Food Research International 62 74-83, 2014.

[4] BLIGH, E.G.; DYER, W.J. A rapid method for total lipid extraction and purification. Canadian Journal of Biochemistry and Physiology. 37:911-917.1959.

[5] BRAGA, A.C.C.; SILVA, A.E.; PELAIS, A.C.A.; BICHARA, C.M.G. POMPEU, D.R. Atividade antioxidante e quantificação de compostos bioativos dos frutos de abricó (Mammea americana). Alimentos e Nutrição, Araraquara v.21, n.1, p. 31-36. 2010.

[6] BRAUNRATH, R.; ISNARDY, B.; SOLAR, B.; ELMADFA, I. Impact of $\alpha-, \gamma^{-}$, and $\delta$-tocopherol on the radiation induced oxidation of rapeseed oil triacylglycerols.. Radiation Physics and Chemistry. v 79, 7, p. 764-769, 2010.

[7] BROUWER, I.A.; GEELEN, A.; KATAN, B.M. n-3 Fatty acids, cardiac arrhythmia and fatal coronary disease. Progress in Lipid Research, v. 45, p. 357-367, 2006.

[8] CAVALCANTE, P.B. Frutas comestíveis da Amazônia. 5.ed. Belém: CEJUP, 279 p, 1991.

[9] CAVAlCANTE, P. B. Frutas comestíveis da Amazônia. 6. ed. Belém, PA: CEJUP, 279 p. 1996.

[10] CHAROENSIRI, R.; KONGKACHUICHAI, R.; SUKNICOM, S.; SUNGPUAG P. Beta-carotene, lycopene, and alphatocopherol contents of selected Thai fruits. Food Chemistry. 113, 202-207, 2009.

[11] CHAUVEAU-DURIOT, B.; DOREAU, M.; NOZIÈRE, P.; GRAULET, B. Simultaneous quantification of carotenoids, retinol, and tocopherols in forages, bovine plasma, and milk: validation of a novel UPLC method. Analytical and Bioanalytical Chemistry. 397:777-790, 2010.

[12] COSTA, N.M.B.; ROSA, C.O.B. (Ed.). Alimentos funcionais. Viçosa: Ed. Folha de Viçosa, 202p. 2006.

[13] DO, T.D.T.; COzZOLINO, D.; MUHLHAUSLER, B.; BOX, A.; ABLE, A.J. Antioxidant capacity and vitamin E in barley: Effect of genotype and storage. Food Chemistry 187 (2015) 65-74.

[14] FARKAS, O.; ZENKEVICH, I.G.; STOUT, F.; KALIVAS, J.H.; HÉBERGER, K. Prediction of retention indices for identification of fatty acid methyl esters. Journal of Chromatography A, v. 1198-1199, p. 188-195, 2008.

[15] FOLCH, J.; LEES, M.; SLOANE S.G.H. A simple method for the isolation and purification of total lipides from animal tissues. The Journal of Biological Chemistry, 226:497-509, 1957.

[16] FOSTER, R.; WILLIAMSON, C.S.; LUNN, J. Culinary oils and their health effects. Food and Nutrition Bulletin. 34, 4. 2009.

[17] GÓRNAŚ, P. Unique variability of tocopherol composition in various seed oils recovered from by-products of apple industry: Rapid and simple determination of all four homologues $(\alpha, \beta, \gamma$ and $\delta$ ) by RP-HPLC/FLD. Food Chemistry. v. 172, 129-134, 2015.

[18] GROOTVELD, M.; C.J.L. SILWOOD, P. ADDIS, A. CLAXSON, B.B. SERRA, M. VIANA. Health effects of oxidized heated oils. Foodservice Research International. 13, 2001.

[19] GUINAZI, M.; MILAGRES, R.C.R.M. PINHEIRO-SANT'ANA, H.M. CHAVES, J. B.P. Tocoferois e tocotrienois em óleos vegetais e ovos. Química Nova, v. 32, n. 8, 2098-2103, 2009.

[20] IACOPINI, P.; BALDI, M.; STORCHI, P.; SEBASTIANI, L. Catechin, epicatechin, quercetin, rutin and resveratrol in red grape: Content, in vitro antioxidant activity and interactions. Journal of Food Composition Analysis, 21, p. 589$598,2008$.

[21] KAMAL-ELDIN, A.; ANDERSSON, R. A Multivariate Study of the Correlation Between Tocopherol Content and Fatty Acid Composition in Vegetable Oils. Journal of the American Oil Chemists Society, v. 74, n. 41997.

[22] LIM, Y.Y.; LIM,T.T.; Tee, J.J. Antioxidant properties of several tropical fruits: A comparative study. Food Chemistry 103. 1003-1008. 2007.

[23] LORENZI, H.; MATOS, F.J.A. Plantas medicinais no Brasil: nativas e exóticas cultivadas. Nova Odessa: Instituto Plantarum, p, 544, 2002. 
[24] LORENZI, H. et al. Frutas brasileiras e exóticasss cultivadas (de consumo in natura). São Paulo: Instituto Plantarum de Estudos da Flora, 672p. 2006.

[25] LUTTERODT, H., SLAVIN, M., WHENT, M., TURNER, E., YU, L. Fatty acid composition, oxidative stability, antioxidant and antiproliferative properties of selected cold-pressed grape seed oils and flours. Food Chemistry. v. 128: 391-399, 2011.

[26] MEHMOOD, T. Optimization of the canola oil based vitamin E nanoemulsions stabilized by food grade mixed surfactants using response surface methodology. Food Chemistry, v. 183, p 1-7, 2015

[27] MORALES, A.L.; DUQUE, C. Free and glycosidically bound volatiles in the mammee apple (Mammea americana) fruit. European Food Research and Technology. 215:221-226, 2002.

[28] NASCIMENTO, W.M.O.; CARVALHO, J.E.U.; MÜLLER, C.H. Propagação do Abricoteiro. Comunicado técnico. ISSN 1517-2201, 2008

[29] PINHEIRO-SANT'ANA, H.M.; GUINAZIA, M.; OLIVEIRA, D.S.; LUCIA, C.M.D. REISA, B.L.; BRANDÃO, S.C.C. Method for simultaneous analysis of eight vitamin E isomers in various foods by high performance liquid chromatography and fluorescence detection. Journal of Chromatography A. v 1218, 47, 25, 8496-8502, 2011.

[30] ROSSO, V.V. DE.; MERCADANTE, A.Z. Identification and Quantification of Carotenoids, By HPLC-PDA-MS/MS, from Amazonian Fruits. Journal of Agricultural and Food Chemistry, 55, 5062-5072, 2007.

[31] RUFINO, M.S.M.; ALVES, R.; BRITO, E.S.; PÉREZ-JIMÉNEZ, J.; SAURA-CALIXTO. F.; MANCINI-FILHO. J. Bioactive compounds and antioxidant capacities of 18 non-traditional tropical fruits from Brazil. Food Chemistry 121 996$1002,2010$.

[32] SOUZA, D.S.; BALLUS, C.A.; OLIVEIRA, W.S.; GODOY, H.T. Cap IV - Perfil quantitativo de tocoferóis e ésteres metílicos de ácidos graxos da semente de tamarindo (Tamarindus indica L.) provenientes de três Estados brasileiro. In: Caracterização e avaliação da capacidade antioxidante da polpa liofilizada enriquecida com compostos bioativos da semente de Tamarindo (Tamarindus indica L.). 2015, 149f. Tese (Doutorado em Ciências de Alimentos) - Faculdade de Engenharia de Alimentos, Universidade Estadual de Campinas, São Paulo. 2015.

[33] TURAN, S.; TOPCU, A.; KARABULUT, I.; VURAL, H.; HAYALOGLU, A.A. Fatty acid, triacylglycerol, phytosterol, and tocopherol variations in kernel oil of malatya apricots from turkey. Journal of Agricultural and Food Chemistry, 55, 10787-10794, 2007.

[34] VILELA, C.; SANTOSA, S.A.O.; OLIVEIRA, L.; CAMACHO, J.F.; CORDEIRO, N.; FREIREA, C.S.R.; SILVESTRE, A.J.D.; The ripe pulp of Mangifera indica L.: A rich source of phytosterols and other lipophilic phytochemicals. Food Research International. v 54, Issue 2, 1535-1540, 2013.

[35] VISENTAINER, J.V.; FRANCO, M.R.B. Ácidos Graxos em Óleos e Gorduras: Identificação e Quantificação. São Paulo: Varela, 2006.

[36] WAGNER, K.-H., ELMADFA, I. Effects of tocopherols and their mixtures on the oxidative stability of olive oil and linseed oil under heating. European Journal of Lipid Science and Technology 102, 624-629. 2000.

[37] WYCOFF, W.; LUO, R.; SCHAUSS, A.G.; NEAL-KABABICK, J.; SABAA-SRUR, A.U.O.; MAIA, J.G.S.; TRANG, K.; RICHARDS, K.M.E.; SMITH, R.E. Chemical and nutritional analysis of seeds from purple and white açaí (Euterpe oleracea Mart.). Journal of Food Composition and Analysis. v. 41, 181-187, 2015. 


\section{Capítulo 7}

Filmes de amido/quitosana adicionados de fibras, nanofibras e fibras mercerizadas obtidas da palha de trigo

\section{Renata Paula Herrera Brandelero}

Evandro Martin Brandelero

Guilherme Landim Santos

Resumo: Filmes de quitosana e amido apresentam alta hidrofilicidade, a adição de fibras deve auxiliar na redução da afinidade destes filmes por água. 0 objetivo foi obter as isotermas e a solubilidade de filmes de amido/quitosana adicionados de fibras naturais, mercerizadas e cristais de celulose obtidas da palha de trigo. Os filmes foram adicionados $7 \%$ de fibra, sendo produzidos pela mistura de $66 \%$ de amido e $34 \%$ de quitosana. Os valores de monocamada $\left(\mathrm{m}_{0}\right)$ foram para filmes adicionados de fibras mercerizadas igual a 0,065 g água/g de filme, enquanto filmes sem fibra apresentaram valor de $m_{\circ}$ de $0,27 \mathrm{~g}$ água/g de filme. A mercerização deve resultar em celulose com menos grupos hidroxilas para ligação com água. A solubilidade também foi menor em filmes com fibras naturais que apresentaram $5,68 \%$ de solubilidade em comparação com filmes sem fibra que apresentaram $30,62 \%$. As fibras reduziram a hidrofilicidade dos filmes.

Palavras Chave: filmes finos, aproveitamento de resíduos, biopolímeros.

Artigo publicado no Congresso de Engenharia de Materiais em 2018 


\section{INTRODUÇÃO}

Resíduos de filmes plásticos não biodegradáveis tem contribuído para aumentar a contaminação ambiental pelo acúmulo de deste em aterros e nos ambientes aquáticos como rios e mares. Filmes biodegradáveis podem ser metabolizados pelos microrganismos do ambiente em $\mathrm{CO}_{2}$ e água, reduzindo a contaminação ambiental. Os polímeros naturais como o amido perfazem um ciclo ecologicamente correto e sustentável, pois o $\mathrm{CO}_{2}$ liberado no processo de biodegradação é utilizado pelas plantas para produzir o próprio polímero, a presença de alta quantidade de amido (pelo menos $50 \%$ ) na formulação dos filmes pode resultar em materiais ecológicos e sustentáveis. (MA et al. 2017, Seligra et al. 2016)

0 amido é um polímero biodegradável, abundante e relativamente de baixo custo, sendo que por técnicas de extrusão e casting resulta em filmes muito semelhantes aos filmes plásticos. Os filmes de amido apresentam solubilidade elevada $30 \%$ em 24 horas de contato com a água e apresenta alta higroscopicidade a partir de $75 \%$ de umidade relativa no ambiente, absorvendo água através de interações do tipo ligações de hidrogênio que ocorre entre água e hidroxila do amido. A água adsorvida pode atuar como um plastificante, ocasionando prejuízos nas propriedades mecânicas dos filmes e nas propriedades de barreira ao vapor de água, limitando a aplicabilidade de filmes de amido (Brandelero, 2016; Sueiro et al., 2016).

A quitosana é o segundo polímero mais abundante, ficando atrás apenas da celulose. Este polímero é obtido da quitina que está presente no exoesqueleto de insetos e de crustáceos, sendo industrialmente um resíduo da pesca. A quitosana é extaída através da desacetilação dos grupos acetaminas da quitina, resultando na formação de grupos aminos que em meio ácido são protonados. A presença de carga positiva nestes grupos gera uma repulsão entre as cadeias poliméricas, facilitando à incorporação da água em meio ácido e a associação desta com os grupos hidroxilas da quitosana. A maior solubilidade da quitosana em comparação com a quitina possibilitou a aplicação deste polímero na área farmacêutica, na agricultura, na indústria de alimentos e na confecção de biomateriais. (Laranjeira e Fávere, 2009).

A quitosana em água comporta-se como um hidrogel, absorvendo água sem solubilizar-se, assim filmes de quitosana/amido são menos solúveis e menos hidrofílicos, devido a associação entre os grupos hidroxilas dos dois polímeros, porém o efeito é dependente da quantidade. Filmes de amido e quitosana são amplamente estudados na área de alimentos, devido ao efeito da quitosana na proliferação de microrganismo patogênicos, além de melhorar as propriedades mecânicas dos filmes de amido, reduzir a pegajosidade em condições de alta humidade, conferindo resistência térmica, opacidade e melhorando a processabilidade em processos de extrusão. No entanto, estes filmes são ainda muitos hidrofílicos o que limita as aplicações em muitas áreas, como em alimentos, limitada pela absorção de água em condições de alta umidade (Ren et al. 2017, Dang e Yoksan, 2016).

A solubilidade de filmes poliméricos pode ser reduzida pela incorporação de fibras lignocelulósicas em materiais poliméricos, uma vez que as fibras são materiais hidrofílicos, praticamente insolúvel em água. As fibras podem melhorar as propriedades mecânicas dos filmes atuando como um reforço nas propriedades mecânicas. 0 emprego das fibras lignocelulósicas em materiais tem sido objeto de muitos estudos uma vez que estes materiais são abundantes e podem ser obtidos por diferentes resíduos industriais. As fibras vegetais são compostas de celulose, hemicelulose e lignina, além disso podemos encontrar substâncias como resinas, saponinas, polifenóis entre outras (María et al. 2011).

Um dos problemas de utilizar as fibras naturais é a fraca interação com a matriz polimérica. Processos químicos e físicos podem ser utilizados para separar a celulose dos demais componentes das fibras. Assim podemos separar a celulose por via química adicionando as fibras naturais em soluções alcalinas, este processo é conhecido na indústria como mercerização. Neste processo a celulose é separada da lignina e da hemicelulose, além do hidróxido de sódio promover a ionização dos grupos $\mathrm{OH}$ para alcóxidos, a presença destes grupos químicos aumenta o contato da fibra na matriz dos filmes e a associação com a matriz polimérica (Beltrami el al. 2014).

A hidrólise ácida das fibras ocorre com a adição de ácido sulfúrico às fibras, grupos sulfatos são carregados negativamente e introduzidos nas mesmas, aumentando a repulsão entre as cadeias poliméricas. 0 ácido promove a desestruturação das regiões amorfas das fibras. As regiões cristalinas não são afetadas pelo ácido e aumentam ao longo das mesmas. A fibra resultante tem alta cristalinidade, e apresentam de 2-20 nm de diâmetro com comprimentos de 500-600 nm, chegando até a 1 um, sendo chamados de nanowhiskers, nanoroods e cristais de celulose. A adição de cristais de celulose em filmes pode melhorar as propriedades mecânicas e a barreira á permeabilidade ao vapor de água, no entanto, existe uma grande atração superficial entre os cristais, ocasionando a formação de agregados, neste caso não resultando nos efeitos esperados quando adicionados aos materiais (María et al, 2011). 
A solubilidade dos filmes é uma propriedade importante dos filmes poliméricos uma vez que estes são hidrofílicos, a redução da água de sorção dos filmes em diferentes condições de umidade pela adição de fibras pode indicar uma maior associação entre as fibras e os polímeros, pois indicam que grupos hidroxilas do amido estão associados por ligações de hidrogênios aos grupos químicos da celulose. A solubilidade dos filmes também pode ser influenciada pela presença das fibras na matriz dos filmes, pois a solubilidade aumenta quando a água entra em contanto com as cadeias poliméricas, assim quanto mais afastadas as cadeias o contanto com a água melhora, sendo os filmes mais solúveis. 0 objetivo do presente trabalho foi avaliar a hidrofilicidade de filmes de amido/quitosana quando adicionados de fibras naturais obtidas da palha de trigo, fibras mercerizadas e fibras após hidrólise ácida (cristais de celulose), estabelecendo as isotermas de sorção e a solubilidade.

\section{MATERIAL E MÉTODOS}

\subsection{MATERIAL}

0 amido utilizado foi amido de mandioca (Pinduca, Paraná) contendo 21\% de amilose. A quitosana de peso molar médio, $75-85 \%$ de desacetilização foi obtida da Sigma-Aldrich (USA). 0 glicerol com $98 \%$ de pureza obtido da empresa Alphatec (Brasil). 0 hidróxido de sódio com 98\% de pureza foi obtido da marca Synth (Brasil). 0 ácido sulfúrico 98\% de pureza marca Synth (Brasil). As fibras naturais foram obtidas da palha de trigo residual obtida após a colheita dos grãos.

\section{MÉTODOS}

\subsection{PREPARO DAS FIBRAS NATURAIS, MERCERIZADAS E CRISTAIS DE CELULOSE}

As fibras naturais foram secas em estufa a $40^{\circ} \mathrm{C}$ por 24 horas, após foram moídas em moinho elétrico, tipo willey utilizando a peneira de 250 mesh. 0 material triturado foi submetido ao processo de mercerização, utilizando uma solução de $\mathrm{NaOH} 40 \%$ na proporção de $50 \mathrm{~g}$ de fibra para $500 \mathrm{~mL}$ de solução, sendo a solução aquecida à $50^{\circ} \mathrm{C}$ por 30 minutos. Após aquecimentos a solução foi filtrada, o filtrado foi lavado com água até que o pH das fibras abaixasse para 7,0. Após as fibras foram branqueadas utilizando uma solução de hipoclorito de sódio a $2 \%$ por 5 minutos á fervura. Após as fibras foram lavadas novamente e encaminhadas para secagem em estufa a $65^{\circ} \mathrm{C}$ por 2 dias. As fibras foram armazenadas em potes plásticos até o momento do uso nos filmes. Os cristais de celulose foram obtidos pesando $10 \mathrm{~g}$ de fibra mercerizada e submetendo-a a hidrólise ácida, utilizando $90 \mathrm{~mL}$ ácido sulfúrico e aquecendo a solução à $50^{\circ} \mathrm{C}$ por 30 minutos. Após a solução foi esfriada e decantada, retirou o excesso de sobrenadante por filtragem, utilizando papel de filtro para soluções coloidais. Acrescentou solução de hipoclorito 2\% por 5 minutos até à fervura. 0 processo de adição de água, decantação foi repetido por várias vezes até que o pH da solução de fibra foi igual a 3,0. A solução foi encaminha à estufa à 65으 $\mathrm{C}$ por 2 dias para secagem das fibras. Na Figura 1 está apresentada a aparência geral das fibras naturais, mercerizadas e dos cristais de celulose obtidos.

Figura 1. Aspecto geral das fibras naturais (Fig 1-A), fibras obtidas por mercerização (Fig. 1-B) e cristais de celulose (Fig. 1-C) obtidas da palha residual da colheita do trigo.

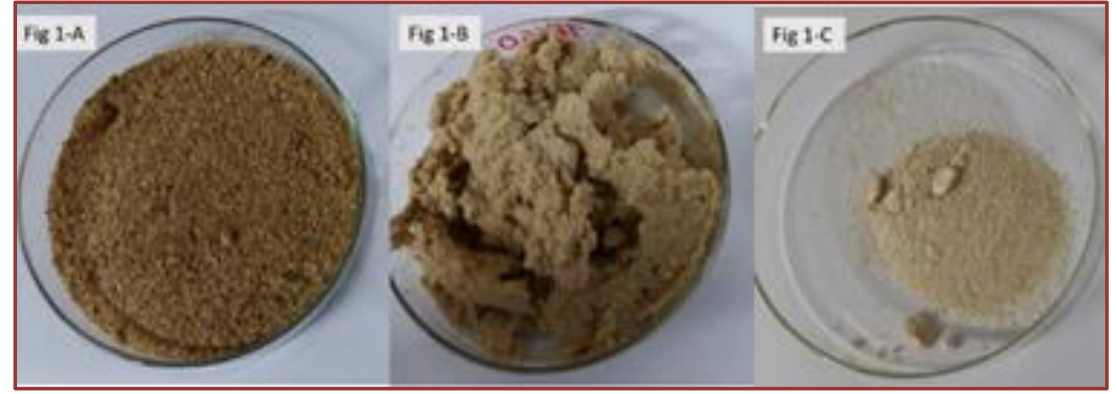




\subsubsection{BTENÇÃO DOS FILMES DE AMIDO/QUITOSANA ADICIONADOS DE FIBRAS}

Os filmes de amido/quitosana foram elaborados na proporção de 66\% de amido para 34\% de quitosana, sendo os filmes adicionados de $7 \%$ sobre a massa total de polímero de fibras naturais (FN), fibras mercerizadas (FM) ou cristais de celulose (CC), o glicerol foi adicionado nos filmes na proporção de $20 \%$ sobre a massa dos polímeros. A solução de amido foi gelatinizada sob agitação à 75ำ $\mathrm{C}$ por 10 minutos. Após a gelatinização do amido a solução de quitosana foi adicionada para obter uma mistura homogênea. As fibras foram adicionadas neste momento. Os filmes foram adicionados de pigmento pretos na proporção de 1\%. Filmes sem adição de fibras serviram de controle. A solução filmogênica foi depositada sobre placas de periglass de $25 \times 54 \mathrm{~cm}$ que foram secas em estufa a $50^{\circ} \mathrm{C}$ por cerca de 24 horas.

\section{DETERMINAÇÃO DAS ISOTERMAS DE SORÇÃO}

\subsection{ISOTERMAS DE SORÇÃO}

As isotermas de sorção dos filmes foram determinadas em diferentes umidades relativas $(11,8 \%, 32,8 \%$, $43,2 \%, 52,9 \%, 64,5$ e $90 \%$ ) a $25^{\circ}$ C. Corpos de provas (20 mm x $20 \mathrm{~mm}$ ) foram condicionados por 30 dias em cloreto de cálcio. Posteriormente foram colocados em recipientes fechados contendo soluções salinas saturadas para obter a URE desejada. Os filmes foram pesados em intervalos regulares até obter três pesagens consecutivas iguais (condição de equilíbrio). A umidade absoluta (em base seca) foi determinada pelo método em estufa (105드, 4 horas). Todos os testes foram conduzidos em triplicata. As isotermas foram modeladas a partir dos valores de umidades obtidos em 11,8\% de UR utilizando o modelo de GAB (Guggenhein-Anderson-de Boer) conforme equação A. 0 programa Statistica 6.0 foi utilizado para realizar a modelagem. Os parâmetros convergiram pelo método de Quasi-Newton.

$$
X_{w}=\frac{C \cdot k \cdot m_{o} \cdot a_{w}}{\left[\left(1-k \cdot a_{w}\right)\left(1-k \cdot a_{w}+C \cdot k \cdot a_{w}\right)\right]}
$$

onde: $\mathbf{C}$ (calor de sorção da monocamada), $\mathbf{k}$ (calor de sorção da multicamada) e mo (monocamada dada em g água/g sólidos) são os parâmetros do modelo, $\mathbf{X}_{\mathbf{w}}$ é a umidade em base seca (g água/g sólidos) e $\mathbf{a}_{\mathbf{w}}$ é a UR/100.

\subsection{DETERMINAÇÃO DA SOLUBILIDADE DOS FILMES}

A solubilidade dos filmes foi determinada em triplicata, para cada tratamento foram obtidos corpos de provas de $20 \mathrm{~mm}$ x $20 \mathrm{~mm}$. Os corpos de provas foram secos em estufa a 105 C por 6 horas. Após cada corpo de prova foi pesado em balança analítica para determinar a massa seca inicial ( $\left.\mathrm{P}_{1}\right)$. Os corpos de provas foram colocados em erlenmeyer contendo $50 \mathrm{~mL}$ de água destilada (pH 7,2). 0 erlenmeyer foram colocados em BOD a 25ำ $\mathrm{C}$ sem agitação por 24 horas. Após as soluções de cada erlenmeyer foram filtradas em papel de filtro. A massa não solúvel foi seca em estufa da 105 $\mathrm{C}$ por 6 horas. As amostras foram pesadas em balança analítica para determinar a massa não solubilizada $\left(\mathrm{P}_{2}\right)$. A solubilidade foi determinada em gramas solúvel por $100 \mathrm{~g}$ do filme pela equação B.

$$
\% S=\frac{P_{1}-P_{2}}{P_{1}} \times 100(\mathrm{~B})
$$

\section{RESULTADOS E DISCUSSÃO}

As isotermas dos filmes foram elaborados e estão apresentadas na Figura 2. Observa-se que as mesmas foram muito similares às obtidas para materiais com alto teor de carboidratos, apresentando curvatura sigmoide e aumento da água de sorção a partir de 75\% de umidade relativa. Resultados similares foram obtidos por outros autores (Leceta et al. 2014, Muller et al. 2009). Os filmes adicionados de fibra mercerizada apresentaram menor água de sorção em todas as condições de umidade, sendo os menos higroscópicos. 
Figura 2. Isotermas dos filmes de amido/quitosana sem adição de fibras (A/Q-SF), com adição de fibras naturais (A/Q-FN), adição de fibras mercerizadas (A/Q-FM) e com adição de cristais de celulose (A/Q-CC).

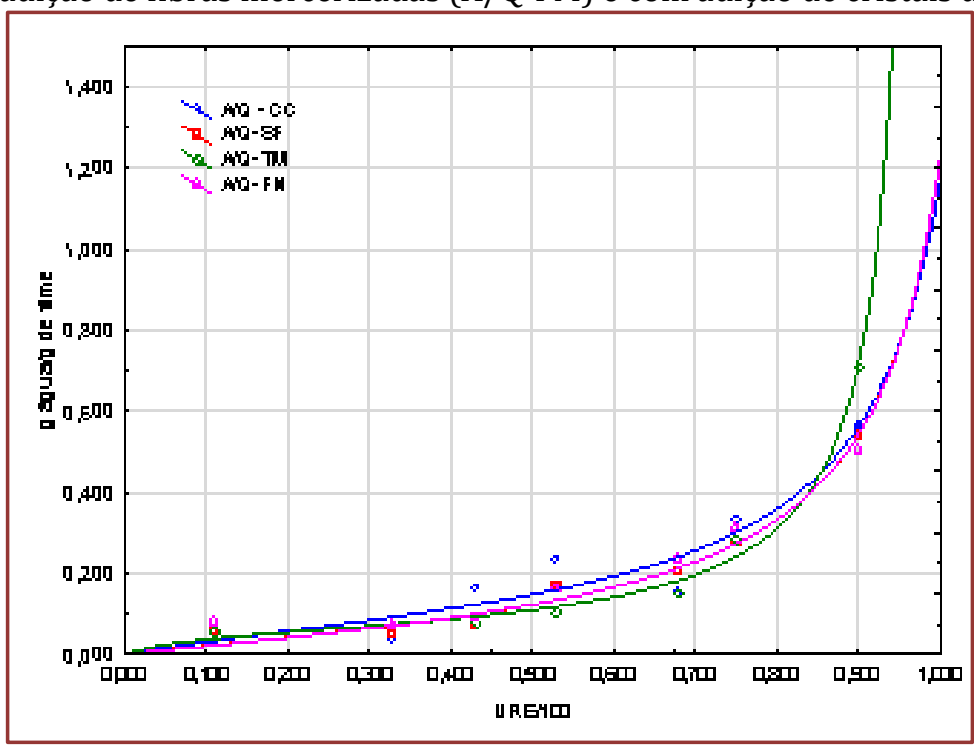

Os parâmetros do modelo de GAB foram determinados e estão apresentados na Tabela 1. Observa-se que a adição de fibras reduziu a água de sorção dos filmes quando comparamos os valores de monocamada de filmes sem fibras com as demais formulações, conforme pode ser visualizado pelos valores de monocamada $\left(\mathrm{m}_{\mathrm{o}}\right)$ determinados (Tabela 1$)$.

Os filmes que receberam as fibras quimicamente modificados apresentaram valores de $m_{0}$ bem menores que os filmes que receberam fibras naturais, indicando que houve uma melhor distribuição das fibras mercerizadas e dos cristais de celulose ao longo da matriz dos filmes se comparado com as fibras naturais, especialmente as fibras mercerizadas. A redução dos valores de monocamada indica que as fibras FM e CC associaram em maior grau com a matriz das cadeias poliméricas, indicando que grupos hidroxilas das fibras associaram aos grupos hidroxilas dos polímeros, reduzindo a disponibilidade dos sítios de ligação com afinidade para água. Conforme Batenburg e Kroon (1997) a mercerização pode resultar na formação de celulose do tipo II que além de ser mais cristalina apresenta ligações de hidrogênio intracadeia, resultando em menor hidrofilicidade que a celulose tipo I, com ligações de hidrogênio projetadas para o espaço além das cadeias poliméricas.

Tabela 1. Parâmetros do Modelo de GAB determinados para filmes de amido e quitosana sem adição de fibras (A/Q SF), para filmes adicionados de fibras naturais (A/Q FN), para filmes adicionados de fibras mercerizadas (A/Q FM) e filmes adicionados de cristais de celulose (A/Q CC).

\begin{tabular}{|c|c|c|c|c|} 
Filme & $\begin{array}{c}\text { Mo (monocamada) } \\
\text { (g água/g de filme) }\end{array}$ & \multicolumn{2}{c}{ C (calor de sorção) } & $\begin{array}{c}\text { K (constante de } \\
\text { sorção nas } \\
\text { multicamadas) }\end{array}$ \\
A/Q SF & 0,270 & 1,06 & 0,76 & $\begin{array}{c}\text { Coeficiente de } \\
\text { Regressão (R) }\end{array}$ \\
\hline A/Q FN & 0,117 & 1,74 & 0,9 & 0,92 \\
\hline A/Q FM & 0,065 & 5,22 & 1,01 & 0,90 \\
\hline A/Q CC & 0,108 & 3,45 & 0,9 & 0,94 \\
\hline
\end{tabular}

$\mathrm{O}$ aumento dos valores de $\mathrm{k}$ (constante de sorção nas multicamadas) indicam maior homogeneidade na estrutura dos filmes, quando k=1 o modelo de isoterma de GAB fica igual ao modelo de BET que supõem que não há diferença de sorção ao longo das diferentes camadas que compõem um material. Os valores de $\mathrm{k}$ dos filmes com fibras FM e dos filmes sem fibras apresentaram k mais próximo a 1, indicando que estes materiais são mais homogêneos, enquanto filmes com fibras naturais (FN) e cristais de celulose (CC) tornaram-se mais heterogêneos. 
Os valores de solubilidade foram determinados para os filmes sem fibras (A/Q-SF), para filmes adicionados de fibras naturais (A/Q-FN) e fibras tratadas (A/Q-FM e A/Q-CC) estão apresentados na Tabela 2. Observa-se que a solubilidade reduziu pronunciadamente nos filmes com fibras naturais, sendo o menor valor ente os tratamentos. Comportamento similar foi determinado por Khan et al. (2012) para filmes de quitosana adicionados de fibras, conforme os autores as fibras são materiais mais cristalinos e menos hidrofílicos que a quitosana, desta forma as fibras atuariam como uma barreira a passagem de água.

No presente trabalho filmes com fibras naturais apresentaram maior efeito que as FM ou CC, o que pode estar relacionado à presença de lignina nas fibras naturais que devido a hidrofobicidade causa repulsão nas moléculas de água, diminuindo a solubilidade. As fibras mercerizadas e os cristais de celulose também diminuíram o valor de solubilidade uma vez que a celulose não é solúvel em água, formando regiões com menor afinidade pela água.

Tabela 2. Valores de solubilidade em água dos filmes de amido/quitosana sem adição de fibras (A/Q SF), para filmes adicionados de fibras naturais (A/Q FN), para filmes adicionados de fibras mercerizadas (A/Q

FM) e filmes adicionados de cristais de celulose (A/Q CC).

\begin{tabular}{|c|c|} 
Filme & $\begin{array}{c}\text { Solubilidade } \\
\text { (g de sólidos solúveis } / 100 \\
\text { g de filme) }\end{array}$ \\
\hline A/Q-SF & $30,6^{\mathrm{a}}$ \\
\hline A/Q-FN & $5,7^{\mathrm{c}}$ \\
\hline A/Q-FM & $17,8^{\mathrm{b}}$ \\
\hline A/Q-CC & $18,8^{\mathrm{b}}$ \\
\hline
\end{tabular}

\section{CONCLUSÃo}

Os filmes adicionados de fibras foram menos hidrofílicos que filmes de amido/quitosana, uma vez que houve redução na água de sorção e na solubilidade na presença das mesmas. As fibras naturais auxiliaram a reduzir a solubilidade, indicando que a presença de lignina reduziu o acesso da água na matriz dos filmes. As fibras mercerizadas e os cristais de celulose reduziram a higroscopicidade dos filmes, indicando que estas fibras estão mais associadas à matriz do filme, uma vez que nestes filmes os valores de monocamada foram menores, indicando que a disponibilidade dos sítios de ligação de vapor de água foi reduzida. 0 efeito está ligado a maior rugosidade das fibras mercerizadas, formação de celulose tipo II e maior cristalinidade dos cristais de celulose. A adição de fibras mercerizadas aos filmes viabilizou a redução da higroscopicidade.

\section{REFERÊNCIA}

[1] Leceta; P. Arana; P. Guerrero, K. de la Caba. Materials Letters, 2014, 128, 125

[2] R. P. H. Brandelero; F. Yamashita; J. Zanela; E. M. Brandelero; J.C. Caetano. Starch, 2015, 67, 191.

[3] Ma, X.; Cheng, Y.; Qin, X.; G. T.; Deng, J.; Liu, X. Hidrophilicity modification nanocellulose nanocrystals improves the physichochemical properties of cassava starch-based nanocomposite films. Food Science and Technology, 86, 318-326, 2017.

[4] Muller, Carmem M. O; Laurindo, J. B.; Yamashita, F. Effect of cellulose fibers addition on mechanical properties and water vapor barrier of starch-based films. Food Hydrocolloids, 23, 1328-1333p. 2009.

[5] Batenburg-Kroon, L. M. J.; Kroon, J. The crystal and molecular structures of cellulose I and cellulose II. Glycoconjucate Journal, 14, 677-690, 1997

[6] Khan, A.; Khan, R. A.; Salmieri, S.; Tien, C. Le; Riedi, B.; Bouchard, J.; Chauve, G.; Tan, V.; Kamal, M. R./ Lacroix, M. Mechanical and barrier properties of nanocrystalline cellulose reinforced chitosanbased nanocomposite films. Carbohydrate Polymers, 90, 1601-1608p. 2012.

[7] Seligra et al. 2016)

[8] Sueiro, A. C.; Faria-Tischer, P. C. S.; Lonni, A. A. S. G.; Mali, S. Filmes biodegradáveis de amido de mandioca, pululana e celulose bacteriana. Química Nova, 39, 9, 1050-1064, 2016.

[9] Laranjeira, M. C. M., Fávere, V. T de. Quitosana: biopolímero funcional com potencial industrial biomédico. Química Nova, $32,3,672-678$., 2009. 
[10] Ren, L. Yan, X.; Zhou, J.; Tong, J.; Su, X. Influence of chitosan concentration on mechanical and barrier properties of corn starch/chitosan films. International Journal of Biological Macromolecules.105, 1636-1643, 2017.

[11] Dang, K. M.; Yoksan, R. Development of thermoplastic starch blown film by incorporating plasticized chitosan. Carbohydrate Polymers, Barking, v. 115, p. 575-81, Jan. 2014.

[12] Beltrami, L. V. R.; Scienza, L. C.; Zattera, A. J. Efeito do tratamento alcalino de fibras de curauá sobre as propriedades de compósitos de matriz biodegradável. Polímeros. 24, 3, p.388-394, 2014. 


\section{Capítulo 8}

\section{Extração e caracterização da composição lipídica da borra de café robusta e arábica}

\section{Cleber Luiz de Moura}

Isabel Craveiro Moreira Andrei

Lisandra Ferreira de Lima

\section{Lyssa Setsuko Sakanaka}

Resumo: A borra de café que gerada em grande quantidade na produção de café solúvel tornou-se um problema por se tratar de um resíduo industrial, porém por apresentar um alto teor de lipídios, uma alternativa comercial viável é a extração e a utilização desse óleo. Este trabalho teve por objetivo extrair e caracterizar a fração lipídica da borra de café Robusta e Arábica, através da transesterificação da via catálise básica e ácida, e posterior caracterização dos ésteres presentes no óleo da borra de café utilizando cromatografia gasosa com espectrometria de massas (GC-MS). Os rendimentos da extração foram em média 19,18\% e 22,16\% para as qualidades Robustas e Arábicas, respectivamente. A transesterificação via catálise ácida mostrou uma maior eficiência na conversão dos ácidos graxos em ésteres, identificando como majoritários o Hexadecanoato de metila e 9,12(Z) Octadecadienoato de Metila, já que na catálise básica ocorre a saponificação de ácidos graxos livres.

Palavras-chave: Borra de café; GC-MS; Hexadecanoato de metila; 9,12(Z) Octadecadienoato de Metila. 


\section{INTRODUÇÃO}

Em tempos de sustentabilidade, uma das maiores preocupações da humanidade é a destinação dos resíduos oriundos do processo de transformação industrial. A partir desta demanda por práticas sustentáveis, insere-se a extração e caracterização do óleo da borra.

O presente estudo deriva da problemática de que nas indústrias de café solúvel ocorre o acúmulo de grande quantidade de borra, resultante do processo de transformação do grão em produtos industrializados. As substâncias presentes nesse óleo são desperdiçadas quando a borra é descartada na terra, ou é utilizada somente como combustível para as caldeiras geradoras de vapor que alimentam o próprio processo de produção.

Sabe-se que o café é um produto agrícola largamente produzido no Brasil. Conforme dados da CONAB (2014), o Brasil é responsável por 33\% da produção mundial de café. Dentre mais de 100 espécies de café existentes, Coffea arabica e Coffea canephora (Robusta) respondem por quase todo o café produzido e comercializado no mundo.

O grão de café torrado contém cerca de 10 a 15\% de ácidos graxos saturados e insaturados. Os óleos essenciais são extraídos da borra de café por meio da utilização de solvente (SANTOS, 2010). A maior parte desses óleos é constituída por ácido palmítico (34,5\%) e linoléico (40,3\%). O perfil de ácidos graxos dos lipídios do café é similar ao dos óleos vegetais comestíveis (Turatti, 2001; Vidal, 2001).

A indústria brasileira de café solúvel representa um importante elo na cadeia de suprimentos do café, uma vez que mais de três milhões de sacas de café verde são consumidas pela indústria anualmente. Freitas, Monteiro e Lago (2000, p. 740) explicitam que o processo de industrialização do café solúvel gera um volume considerável de resíduos (borra). "Em média, para cada tonelada de café obtém-se $480 \mathrm{~kg}$ da borra. Enquanto o café solúvel possui $0,1 \%$ de lipídios, em base seca, a borra possui cerca de $20 \%$ de óleo".

Na indústria de café solúvel, para cada tonelada de café verde processada, são gerados $650 \mathrm{Kg}$ de borra; para cada quilo de café solúvel produzido, são gerados dois quilos de borra úmida. É importante salientar que os resíduos produzidos em escalas menores, em residências, bares, restaurantes ou cafeterias, não têm sido contabilizados (Vegro; Carvalho, 2006).

Assim como a casca de café, a borra contém cafeína, taninos e polifenóis, porém em menor quantidade. A presença desses compostos a torna um resíduo tóxico à natureza, limitando seu uso à ração animal, adubo e como combustíveis, em substituição e/ou adição à lenha (Vegro; Carvalho, 2006).

0 resíduo sólido resultante da produção de café solúvel, proveniente do processo de extração, representa $50 \%$ da massa de café cru utilizado para alimentar o processo. Assim, uma grande quantidade de resíduos é gerada anualmente na produção de café solúvel, exigindo das indústrias o desenvolvimento de um plano de gestão de resíduos de acordo com a legislação vigente. (Pujol, et al, 2013, p. 423)

Os resíduos de café contêm grandes quantidades de compostos orgânicos (ácidos graxos, lignina, celulose, hemicelulose e outros polissacarídeos) que justificam a sua valorização. Pujol et. al. (2013) reportam-se a pesquisas recentes que têm investigado resíduos de café como recursos biológicos para vários outros fins.

\section{MATERIAL E MÉTODOS}

\subsection{OBTENÇÃO DAS AMOSTRAS}

As amostras de café verde, café torrado e borra de café, referentes a duas espécies de café: a Coffea arábica e a Coffea canephora (café robusta) foram obtidas em uma indústria de café solúvel da região metropolitana de Londrina, PR. A borra de café coletada do processo industrial foi seca em estufa e armazenada em freezer, de forma a minimizar os processos de oxidação ao ar e contaminação por fungos.

\subsection{EXTRAÇÕES POR SOXTEC UTILIZANDO ÉTER DE PETRÓLEO}

Para determinação da porcentagem de lipídios totais foram utilizados aproximadamente $10 \mathrm{~g}$ de cada uma das amostras, e acondicionas em cartuchos de celulose. Adicionou-se $100 \mathrm{~mL}$ de éter de petróleo P.A para extração, e o Extrator Foss operou-se em uma temperatura de $70^{\circ} \mathrm{C}$ por duas horas após a extração, a mistura óleo/éter de petróleo foi transferida para um evaporador rotatório (a $50^{\circ} \mathrm{C}$, sob vácuo de 400 $\mathrm{mmHg}$ ). 0 solvente foi separado e os lipídios totais foram isolados e quantificados. 
As análises foram realizadas em quintuplicatas, sendo o resultado expresso pela média \pm incerteza. A porcentagem de lipídios totais presente nas amostras foi calculada segundo a Equação 1.

$$
\text { Rendimento (\% lipídios totais) }=\frac{\text { massa de óleo }(g)}{\text { massa de borra utilizada }(g)} * 100(1)
$$

\subsection{TRANSESTERIFICAÇÃO}

\section{Catálise básica}

A transesterificação via catálise básica, foi realizada de acordo com o método descrito pela norma ISO 5509 de 1978.

Pesou-se $1 \mathrm{~g}$ de óleo, adicionou $10 \mathrm{~mL}$ de $\mathrm{n}$-heptano e agitou. Em seguida adicionou-se $0,5 \mathrm{~mL}$ de solução metoxido de sódio $2 \mathrm{M}$, agitou por 20 s. Após a separação das fases, coletou o sobrenadante para análise em cromatógrafo gasoso acoplado com espectrometria de massas (GC-MS).

\section{Catálise ácida}

Para transesterificação de catálise ácida, utilizou-e o método descrito Hartman e Lago 1973 (HLA).

Pesou-se 0,5g de óleo da borra de café, adicionou-se 5,0 mL de solução de $\mathrm{NaOH} \mathrm{0,50} \mathrm{mol.L-1} \mathrm{em} \mathrm{metanol,}$ levou-se a mistura para aquecimento por $5 \mathrm{~min}$. sob refluxo. Adicionou-se $15 \mathrm{~mL}$ do reagente de transesterificação, (2g de $\mathrm{NH} 4 \mathrm{Cl}$ dissolvidos em $60 \mathrm{~mL}$ de metanol e adicionado $3 \mathrm{~mL}$ de $\mathrm{H} 2 \mathrm{SO} 4$ (conc.), aquecido por $15 \mathrm{~min}$.), aqueceu-se a mistura por $3 \mathrm{~min}$. sob refluxo. Após essa etapa realizou-se a separação do produto de reação utilizando funil de separação juntamente com $25 \mathrm{~mL}$ de éter de petróleo e $50 \mathrm{~mL}$ de água deionizada, separando-se a fase orgânica a qual foi lavada por mais 2 vezes com $25 \mathrm{~mL}$ de água deionizada, seguida de evaporação para posterior análise.

\subsection{ANÁLISE POR CROMATOGRAFIA GASOSA ACOPLADA A ESPECTROMETRIA DE MASSAS (GC-MS)}

A porcentagem de área dos ésteres metílicos de ácidos graxos (EMAG) foi avaliada por GC/MS (modelo $6890 \mathrm{~N} /$ detector MS- Agilent 5973). Utilizou-se coluna capilar HP-INOWAX (60m x 0,25mm x 0,25mm) com injeção em modo splitless com temperatura de $250^{\circ} \mathrm{C}$ e forno com temperatura inicial de $120^{\circ} \mathrm{C}$, com rampa de $25^{\circ} \mathrm{C} /$ minutos, até atingir $270^{\circ} \mathrm{C}$. 0 gás de arraste (Hélio ultra puro) foi mantido a fluxo constante de $1 \mathrm{~mL} / \mathrm{min}$, injetou-se o volume de $1 \mu \mathrm{L}$. 0 equipamento GC-MS operou em modo SCAN com varredura de 35 a 450 u.m.a.

0 detector de massas operou nas seguintes condições: energia de ionização: $70 \mathrm{eV}$, temperatura da interface: $280{ }^{\circ} \mathrm{C}$, temperatura do quadrupolo: $150 \stackrel{\circ}{\circ} \mathrm{C}$, temperatura da fonte de íons: $230{ }^{\circ} \mathrm{C}$. Os dados gerados foram analisados utilizando o software MSD Chemstation acoplado com a biblioteca de espectros de massa NIST/2008.

\section{RESULTADOS E DISCUSSÃO}

\subsection{RENDIMENTOS DE LIPÍDIOS TOTAIS}

A tabela 1 apresenta os resultados da extração de lipídios totais das borras de arábica e robusta comparada ao da extração do café torrado. 
Tabela 1 - Extração de Lipídios Totais

\begin{tabular}{|c|c|c|c|c|}
\hline \multirow{2}{*}{ Extração } & \multicolumn{2}{|c|}{ \% de Lipídios Totais Café Robusta } & Café Torrado de Lipídios Totais Café Arábica & Borra de Café \\
\hline $1^{\text {o }}$ & Café Torrado & Borra de Café & 15,46 & 14,87 \\
\hline $2^{\text {o }}$ & 8,68 & 18,41 & 14,64 & 22,99 \\
\hline $3^{\text {o }}$ & 9,08 & 19,06 & 14,47 & 21,74 \\
\hline $4^{\text {o }}$ & 9,06 & 19,81 & 15,09 & 22,16 \\
\hline $5^{\text {o }}$ & 9,06 & 19,92 & $14,87 \pm 0,48$ & $22,16 \pm 0,77$ \\
\hline Média & $9,06 \pm 0,22$ & $19,18 \pm 0,76$ & 21,93 \\
\hline
\end{tabular}

Fonte: Desenvolvimento próprio

Observa-se que a borra de café Robusta apresentou um rendimento médio de 19,18\% $\pm 0,76$ já a borra da qualidade arábica foi de $22,16 \% \pm 0,77$, mostrando assim um alto teor de lipídios totais na borra de café, este resultado esta de acordo com descrito por Freitas, Monteiro e Lago (2000, p. 740), o qual afirma que a borra possui cerca de $20 \%$ de lipídios em base seca.

Também podemos observar que o percentual de lipídios totais na borra é superior ao encontrado no café torrado, o que pode ser explicado pelo processo produtivo, onde grande parte dos sólidos solúveis são extraídos, e somente $0,1 \%$ dos lipídios estão presentes no café solúvel.

\subsection{CARACTERIZAÇÃO DA COMPOSIÇÃO LIPÍDICA DAS BORRAS ARÁBICA E ROBUSTA}

Com base nos resultados apresentados na tabela 2, podemos observar que através da reação de transesterificação por catálise básica, a análise da composição lipídica apresentou um alto percentual Ácido Hexadecanoico. Este resultado propõe que óleo extraído da borra é constituído de ácidos graxos livres, os quais não são transesterificados em meio básico. Segundo Bannon et al., 1982; Gutnikov (1995), a desvantagem da catálise básica é a não conversão dos ácidos graxos em ésteres metílicos o que leva o favorecimento à reação de saponificação.

Tabela 2 - Caracterização da fração lipídica via extrator Soxtec em \% de área

\begin{tabular}{|c|c|c|c|c|}
\hline Composto & \multicolumn{2}{|c|}{ Catálise Básica } & \multicolumn{2}{c|}{ Catálise Ácida } \\
\hline Hexadecanoato de metila & $\begin{array}{c}\text { Borra de Café } \\
\text { Robusta }\end{array}$ & $\begin{array}{c}\text { Borra de Café } \\
\text { Arábico }\end{array}$ & $\begin{array}{c}\text { Borra de Café } \\
\text { Robusta }\end{array}$ & $\begin{array}{c}\text { Borra de Café } \\
\text { Arábico }\end{array}$ \\
\hline Octadecanoato de Metila & 3,4 & 11,15 & 31,96 & 31,08 \\
\hline (Z), 9-Octadecenoato de Metila & 1,78 & 4,11 & 12,00 & 11,35 \\
\hline 9,12 (Z), -Octadecadienoato de & 1,33 & 3,38 & 11,30 & 39,63 \\
\hline $\begin{array}{c}\text { Metila } \\
\text { Eicosanoato de Metila }\end{array}$ & 5,03 & 15,21 & 36,58 & 5,02 \\
\hline Docosanoato de Metila & 15,63 & 1,4 & 6,16 & 1,60 \\
\hline Ácido Hexadecanoico & 72,25 & 48,12 & 1,99 & Traço \\
\hline
\end{tabular}

Fonte: Desenvolvimento próprio

Através da transesterificação via catálise ácida, cujos resultados são apresentados na tabela 2, caracterizou-se de forma mais segura a composição das borras analisadas, pois ocorreu a total conversão dos ácidos graxos em ésteres, o que não indica diferença entre as mesmas. 


\section{CONCLUSÃO}

Através dos rendimentos obtidos na extração da fração lipídica da borra de café, podemos afirmar que a utilização deste resíduo para tal proposito é uma alternativa viável industrialmente, uma vez que se obteve em média 19,18\% na qualidade Robusta e 22,16\% para qualidade Arábica de óleo em base seca.

Na caracterização desses óleos por GC-MS, após a reação de transesterificação via catálise básica, pode-se observar que eles possuem uma grande quantidade de ácidos graxos livres, obtendo-se como um alto percentual de Ácido Hexadecanoico, o qual não foi convertido em éster. A realização de transesterificação via catálise ácida mostrou uma maior eficiência na reação convertendo os triglicerídeos e todos os ácidos graxos livres presentes no óleo em ésteres, favorecendo uma maior confiabilidade nos resultados da caracterização da fração lipídica por GC-MS. Sabendo-se que o processo de extração industrial do café solúvel é realizado em pressões e temperaturas drásticas, justifica-se a presença do grande percentual de acidez nos óleos oriundos da borra, e o resultado obtido permite afirmar que este material é pouco viável para produção de biodiesel via catálise básica, pois a reação tende à saponificação.

\section{REFERÊNCIAS}

[1] Bannon, C. D.; Breen, G. J.; Craske, J. D.; Hai, N. T.; Harper, N. L.; O'Rourke, K. L. (1982). Analysis of fatty acid methyl esters with high accuracy and reliability. III. Literature review of and investigations into the development of rapid procedures for the methoxide-catalysed methanol of fats and oils. Journal of Chromatography, 247, 71-89.

[2] CONAB. (Companhia Nacional de Abastecimento) Acompanhamento da safra brasileira. (2014) Café. Safra 2014. Brasília: café - v. 1, n. 1

[3] D. Pujol, C. Liu, J. Gominho, M.À. Olivella, N. Fiol, I. Villaescusa, H. Pereira. (2013) The chemical composition of exhausted coffee waste. Industrial Crops and Products, 423- 429.

[4] Freitas, S. P., Monteiro, P. L., Lago, R. C. A. (2000). Extração do óleo da borra de café solúvel com etanol comercial. In: Simpósio Nacional dos Cafés do Brasil. Poços de Caldas.

[5] Gutnikov, G. (1995). Fatty acid profiles of lipid samples. Journal of Chromatography, 671, 71-89.

[6] Hartman, L.; Lago, R. C. A. (1973). Rapid preparation of fatty acid methyl fromlipids. Lab. Pract, 22, 474-476.

[7] International Organization for Standardization (ISO 5509). (1978) Animal andvegetable fats and oils Preparation of methyl esters of fatty acids.International Organization for Standardization - ISO, 1-6.

[8] Santos, D. M. dos (2010). Desenvolvimento de método para a obtenção de energia a partir da produção de biodiesel via extração de óleo de borra de café em escala laboratorial. (Dissertação de Mestrado), USP, São Paulo.

[9] Turatti, J, M. (2001). Extração e caracterização de óleo de café. In: Simpósio de pesquisa de cafés do Brasil, Vitória p. 1533-1539.

[10] Vegro, C. L. R.; Carvalho, F. C. (2006). Disponibilidade e utilização de resíduos gerados no processamento agroindustrial do café. Inf. Econ., v. 24, p. 9-16.

[11] Vidal, H. M. Composição lipídica e a qualidade do café (Coffea arábica L.) durante armazenamento. (2001). Dissertação (Mestrado em Agroquímica) - Universidade Federal de Viçosa, MG. 


\section{Capítulo 9}

Viabilidade de Lactobacillus Acidophilus Microencapsulado com pectina armazenado em temperatura de refrigeração

\section{Lucas Nachtigal}

Maria Fernanda da Silveira Cáceres de Menezes

Cassandra de Deus

Bruna de Souza da Fonseca

Cristiano Ragagnin de Menezes

Resumo: 0 objetivo deste estudo consistiu na obtenção de micropartículas de pectina obtidas por gelificação iônica externa como agente encapsulante de Lactobacillus acidophilus a fim de aumentar a viabilidade do probiótico durante o armazenamento refrigerado. Foi realizada a determinação do tamanho médio das partículas, a morfologia e a quantificação de Lactobacillus acidophilus microencapsulado e livre, armazenados à $5^{\circ} \mathrm{C}$, durante 60 dias. No presente estudo, obteve-se um tamanho médio de $224,50 \mu \mathrm{m}$ e o resultado da microscopia ótica mostrou micropartículas de forma esférica, bem definida protegendo a cultura probiótica. Quanto a viabilidade dos L. acidophilus, livres e microencapsulados, observou-se que o processo de microencapsulação foi satisfatório, pois apresentou melhores contagens ao longo do período e manteve a viabilidade do micro-organismo por 45 dias, enquanto que os probióticos livres permaneceram viáveis por 30 dias de armazenamento refrigerado.

Palavras-Chave: microencapsulação, gelificação iônica, viabilidade, probiótico. 


\section{INTRODUÇÃO}

A microencapsulação é uma tecnologia que tem sido aplicada no meio científico e na indústria de alimentos com a função de proteger as culturas probióticas e permitir a sua liberação controlada, pois a viabilidade destes micro-organismos é importante para que atinjam o local de ação específico e promovam os benefícios a saúde do consumidor (Burgain et al., 2011). Segundo, a Organização Mundial de Saúde, os probióticos são organismos vivos, que quando administrados em quantidades adequadas conferem benefícios à saúde do consumidor, melhorando o equilíbrio da flora microbiana (FAO /WHO, 2002). A fim de alcançar estes benefícios é necessário o consumo contínuo dos probióticos, e estes devem permanecer com contagens mínimas de $10^{6} \mathrm{UFC} / \mathrm{g}$ quando atingirem o intestino (FAO /WHO, 2002). Entretanto, os probióticos em geral, e algumas estirpes em particular, têm baixa resistência a presença de oxigênio, luz, pH e temperatura, condições que influenciam na sua viabilidade (Mukai-Corrêa, 2008; Martin et al., 2015). Um exemplo, consiste no gênero lactobacilos, o qual apresenta temperatura ideal de crescimento entre $35^{\circ} \mathrm{C}$ e $45^{\circ} \mathrm{C}$, com baixo crescimento em temperaturas inferiores a $15^{\circ} \mathrm{C}$ (Bergey's, 2000).

Dessa forma, a gelificação iônica externa tem se demonstrado uma técnica viável de microencapsulação dessas culturas, pois é realizado em temperatura ambiente e não causa danos as células bacterianas, conferindo maior viabilidade destes quando comparados a micro-organismos livres. Este método consiste em um processo físico de microencapsulação de probióticos em polímeros, a qual é realizada por atomização de uma solução contendo o polímero e a cultura probiótica, por meio de um bocal de alta pressão, que irá gotejar em uma solução contendo cloreto de cálcio $\left(\mathrm{CaCl}_{2}\right)$, para que ocorra a solidificação por gelatinização iônica (Etchepare et al., 2016).

Polímeros naturais têm sido estudados, como a pectina, matéria-prima que pode ser obtida comercialmente ou a partir da extração de resíduos da indústria cítrica. As pectinas consistem em complexos de polissacarídeos estruturais presentes em vários tecidos vegetais, apresentam caráter hidrofílico, devido à presença de grupos polares, e por isso, tem a propriedade de envolver grande quantidade de água, produzindo uma solução viscosa. É amplamente utilizada na indústria de alimentos, devido sua capacidade de formar géis (Araújo, 2006). Assim, o objetivo deste trabalho consistiu na obtenção de micropartículas de pectina obtidas por gelificação iônica externa como agente encapsulante de Lactobacillus acidophilus no intuito de proteger e aumentar a viabilidade do probiótico durante o armazenamento refrigerado.

\section{MATERIAL E MÉTODOS}

\subsection{MATERIAIS}

Os materiais utilizados foram: cultura probiótica de Lactobacillus acidophilus La-14 (Danisco, São Paulo, Brasil), pectina cítrica de baixa metoxilação (CPKelco, Brasil S/A), cloreto de cálcio (Vetec, Rio de Janeiro, Brasil), agar MRS (Himedia, Curitiba, Paraná, Brasil) e caldo MRS (Himedia, Curitiba, Paraná, Brasil).

\subsection{MÉTODOS}

Preparo da cultura probiótica: Foram pesados $1 \mathrm{~g}$ da cultura probiótica Lactobacillus acidophilus, em 100 $\mathrm{mL}$ de caldo MRS e incubados em estufa a $37^{\circ} \mathrm{C}$ por 15 horas. Posteriormente, centrifugou-se a cultura à $4670 \mathrm{G}, 2^{\circ} \mathrm{C}$ por 15 minutos, e descartou-se o caldo sobrenadante. Lavou-se a biomassa com $1 \mathrm{~mL}$ de solução salina ( $\mathrm{NaCl}$ 0,85\%). Para a determinação da contagem probiótica diluiu-se $1 \mathrm{ml}$ da matriz, contendo a cultura, em solução salina estéril $0,9 \%$ até a diluição de $10^{-12}$, para obtenção de aproximadamente $12 \log \mathrm{UFC} \mathrm{g}^{-1}$, as quais foram plaqueadas em ágar MRS e incubadas em jarras com geradores de anaerobiose em estufa bacteriológica a $37^{\circ} \mathrm{C}$ por $72 \mathrm{~h}$.

Produção de micropartículas de pectina por gelificação iônica externa: As partículas foram produzidas por gelificação iônica, seguindo a metodologia descrita por Boscariolli (2010), onde uma solução aquosa de pectina $2 \%$ foi pulverizada por meio de um atomizador de duplo fluido, medindo $1 \mathrm{~mm}$ de diâmetro e distante $12 \mathrm{~cm}$ entre a ponta do atomizador e a solução de cloreto de cálcio $(0,1 \mathrm{M})$. A pressão de ar comprimido foi de $0,688 \mathrm{Kgf} / \mathrm{cm}^{2}$ e a velocidade de $0,555 \mathrm{~mL} / \mathrm{h}$, conforme Souza et al. (2012) com adaptações. As micropartículas permaneceram por 30 minutos em contato com o cloreto de cálcio para endurecimento, e posteriormente foram lavadas com água estéril e filtradas. 
Tamanho médio de distribuição das micropartículas: 0 tamanho médio das micropartículas úmidas refrigeradas foi avaliado no equipamento Mastersizer 2000, unidade de amostragem Hydro 2000S (Malvern, Germany), utilizando água como meio de dispersão.

Microscopia ótica: A morfologia das micropartículas foi observada em microscópio ótico (Carl Zeiss Axio Scope A1, Oberkochen, Germany).

Viabilidade da cultura probiótica microencapsulada: A viabilidade das cepas probióticas contidas nas micropartículas foi determinada através da contagem bacteriana total por meio de plaqueamento em ágar MRS e incubação à $37^{\circ} \mathrm{C}$ por 72 horas em jarras contendo geradores de anaerobiose. As micropartículas obtidas foram acondicionadas em coletores estéreis e armazenadas sob temperatura de refrigeração $\left(5^{\circ} \mathrm{C}\right)$ para o acompanhamento da vida de prateleira. As análises foram realizadas quinzenalmente, durante 60 dias de acondicionamento refrigerado $\left(5^{\circ} \mathrm{C}\right)$, segundo Oliveira et al. (2007).

\section{RESULTADOS E DISCUSSÃO}

\subsection{TAMANHO MÉDIO DE DISTRIBUIÇÃO DAS MICROPARTÍCULAS}

A Tabela 1, demonstra os resultados obtidos para os tamanhos médios das micropartículas.

Tabela 1 - Distribuição de tamanho das micropartículas de pectina.

\begin{tabular}{|c|c|c|c|c|c|}
\hline $\begin{array}{c}\text { Micropartícula de } \\
\text { pectina }\end{array}$ & $\operatorname{Dn}(10)(\mu \mathrm{m})$ & $\operatorname{Dn}(50)(\mu \mathrm{m})$ & $\operatorname{Dn}(90)(\mu \mathrm{m})$ & $\mathrm{D} 4 ; 3(\mu \mathrm{m})$ & $\begin{array}{c}\text { Índice de } \\
\text { dispersão } \\
(\text { Spam })\end{array}$ \\
\cline { 2 - 5 } & 25,31 & 90,17 & 260,65 & 224,50 & 1,73 \\
\hline
\end{tabular}

A distribuição de tamanho das partículas apresentou-se normal, no entanto, os valores indicaram uma grande variedade de tamanho, como mostra os valores das médias de distribuição, Dn (10), Dn (50), Dn (90) na Tabela 1. Segundo a literatura, esse efeito é atribuído ao uso do atomizador de duplo fluido para produzir as micropartículas, devido aos fatores de: vazão do ar comprimido, viscosidade da solução do polissacarídeo, distância do atomizador à solução de cloreto de cálcio e a concentração da solução de cloreto de cálcio (Aguilar et al., 2015). Enquanto que o tamanho médio das micropartículas de pectina, situou-se entre 224,5 $\mu \mathrm{m}$. Resultados semelhantes foram encontrados por Aguilar et al. (2015) quando produziram micropartículas de pectina-alginato com o tamanho médio de $261 \mu \mathrm{m}$. Entretanto, Gadalla et al. (2015) produziram micropartículas de pectina-quitosana com tamanho médio de $580 \mu \mathrm{m}$ a $720 \mu \mathrm{m}$ (Gadalla et al., 2015). O parâmetro de tamanho de partículas é um dos mais relevantes para a incorporação dos probióticos microencapsulados em produtos alimentícios, pois quanto menor o seu tamanho, menor será a sua percepção e textura quando incorporado a um alimento (Burgain, et al. 2011).

\subsection{CARACTERIZAÇÃO MORFOLÓGICA DAS MICROPARTÍCULAS}

As imagens obtidas por microscopia ótica apresentaram as características morfológicas das micropartículas de pectina e estão ilustradas na Figura 1. 
Figura 1 - Microscopia ótica das micropartículas de pectina contendo Lactobacillus acidophilus (40x).

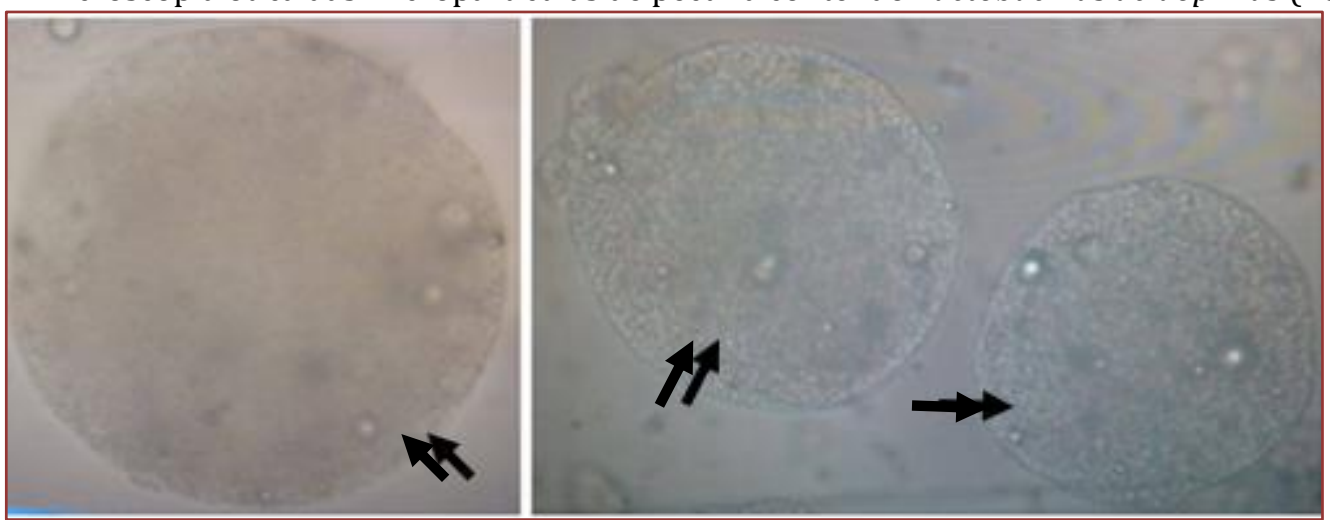

Fonte: próprio autor.

Por meio das imagens de morfologia das micropartículas de pectina (Figura 1), verificou-se que apresentaram forma esférica contendo os micro-organismos distribuídos uniformemente por toda partícula, como indicam as setas na figura. Rodrigues et al. (2014) e Mukai-Correa et al. (2008) também obtiveram microcápsulas úmidas por gelificação iônica de forma esférica ou aproximadamente esféricas.

\subsection{VIABILIDADE DA CULTURA PROBIÓTICA MICROENCAPSULADA DURANTE 60 DIAS DE ARMAZENAMENTO REFRIGERADO}

A viabilidade da cultura probiótica de Lactobacillus acidophilus livre e microencapsulas em pectina $2 \%$, foram analisadas durante 60 dias de armazenamento refrigerado $\left(5^{\circ} \mathrm{C}\right)$, e os resultados encontram-se na Tabela 2 .

Tabela 2. Viabilidade de Lactobacillus acidophilus (log UFC/g) armazenados à 5ํㅡ por 60 dias.

\begin{tabular}{|c|c|c|c|c|c|}
\hline \multirow{2}{*}{ Probióticos } & \multicolumn{5}{|c|}{ Período de armazenamento (dias) } \\
& 0 & 15 & 30 & 45 & 60 \\
\hline Livres & $12,5^{\mathrm{a} A}$ & $10,31^{\mathrm{a}}$ & $6,92^{\mathrm{aC}}$ & $4,87^{\mathrm{a}}$ & $2,62^{\mathrm{aE}}$ \\
\hline Microencapsulados & $8,75^{\mathrm{bA}}$ & $6,49^{\mathrm{bB}}$ & $6,36^{\mathrm{aB}}$ & $6,08^{\mathrm{bB}}$ & $5,37^{\mathrm{bC}}$ \\
\hline
\end{tabular}

Letra minúscula na coluna: diferença significativa entre as amostras no mesmo dia. Letra maiúscula na linha: diferença significativa da mesma amostra em dias diferentes (Teste de Tukey $p<0,05$ ). Os valores obtidos são as médias das triplicatas.

Analisando a Tabela 2, é possível observar que houve diferença significativa $(\mathrm{p}<0,05)$ entre as contagens dos probióticos livres comparados aos microencapsulados, principalmente nos primeiros 15 dias de armazenamento, com reduções acima de 3 ciclos logarítmicos. Em um primeiro momento, este resultado demonstrou redução da viabilidade inicial da cultura microencapsulada para se realizar testes de armazenamento, visto que o principal requisito de cultura probiótica é manter-se viável e em níveis acima de 6 log UFC/g (FAO/OMS, 2001). Sobretudo, a cultura livre apresentou menor viabilidade que a cultura microencapsulada ao longo do armazenamento refrigerado.

Quanto a viabilidade das culturas microencapsuladas armazenadas à temperatura de refrigeração, podese dizer que houve um decréscimo significativo inicial, do dia zero aos 15 dias de armazenamento, apresentando diferenças significativas $(\mathrm{p}<0,05)$. Atribuiu-se essa redução na viabilidade microbiana, à adaptação do micro-organismo microencapsulado à temperatura de refrigeração, pois no restante dos dias analisados, houve menor redução microbiana e manteve-se a viabilidade do probiótico até os 45 dias de armazenamento. Etchepare (2016) também observou uma redução significativa, também acima de 3 ciclos logarítimos, nas contagens de L. acidophilus microenpsulado em matriz de alginato de sódio, do dia zero $(9,78 \mathrm{log} \mathrm{UFC} / \mathrm{g}$ ) aos 15 dias (6,70 log UFC/g) de armazenamento refrigerado. Os estudos de Etchepare (2016) corroboram com o nosso, pois observou-se o mesmo comportamento para a cultura probiótica em estudo, ambos trabalhos apontam que o micro-organismo sofreu danos provocados pela baixa temperatura, mesmo estando microencapsulado. Após os 15 dias de armazenamento, as reduções microbianas, foram amenas, sugerindo que o micro-organismo microencapsulado adaptou-se a essa condição, o que não aconteceu com a cultura livre, que não apresentou resistência a baixa temperatura e reduziu significativamente. 
Aos 60 dias de armazenamento tanto os probióticos livres, quanto os microencapsulados apresentaram-se inviabilizados, pois as contagens estavam abaixo de 6 log UFC/g. Neste período de análise, deve-se fazer uma ressalva, pois as micropartículas úmidas de pectina apresentaram contaminação visível por fungos deteriorantes, o que pode ter favorecido a degradação da partícula e do micro-organismo, uma vez que o conteúdo de água de partículas probióticas é um fator crítico que influencia a estabilidade da bactéria durante o armazenamento (Etchepare, 2016).

Assim, pode-se dizer que aos 45 dias de armazenamento refrigerado, as micropartículas de pectina mantiveram a quantidade mínima exigida de viabilidade dos probióticos (6,08 log UFC/g) comparada aos probióticos livres que apresentaram menor vida de prateleira, 30 dias de armazenamento refrigerado.

\section{CONCLUSÕES}

Os resultados mostraram que as micropartículas de pectina contendo Lactobacillus acidophilus apresentaram melhores resultados de viabilidade do probiótico no decorrer dos 60 dias de armazenamento, sob temperatura de refrigeração, quando comparados a cultura livre. Além disso, os resultados de tamanho médio e morfologia de partícula foram adequados, demonstrando que a técnica de gelificação iônica externa e o revestimento de pectina podem ser utilizados com para aplicação destes micro-organismos microencapsulados em alimentos refrigerados.

\section{AGRADECIMENTOS}

Ao Programa Institucional de Incentivo à Qualificação Profissional dos Servidores do Instituto Federal Farroupilha.

\section{REFERÊNCIAS}

[1] Aguilar, K.C.; Tello, F.; Bierhalz, A.C.K.; Romo, M.G.G.; Flores, H. E.M.; Grosso, C.R.F. Protein adsorption onto alginate-pectin microparticles and films produced by ionic gelation. Journal of Food Engineering, v. 154, p. 17-24, 2015.

[2] Araújo, J.M.A., Química de Alimentos - Teoria e Prática, Ed. UFV, Viçosa, MG, 2006.

[3] Bergey's Manual of Determinative Bacteriology, Ed: Holt, J. G.; Krieg, N. R.; Sneath, P. H. A.; Staley, J. T.; Williams, S. T. Lippincott Williams \& Wilkins, Philadelphia, 9a Ed., 2000. 787 p.

[4] Boscarioli, M. P. M. Influência de prebióticos na encapsulação de bactérias probióticas adicionadas em sorvete. 2010. Dissertação (Mestrado da Escola de Engenharia Mauá) Centro Universitário do Instituto Mauá de Tecnologia, 2010.

[5] Burgain, J.C.; Gaiani, C.; Linder, M.; Scher, J. Encapsulation of probiotic living cells: From laboratory scale to industrial applications. Journal of Food Engineering, v. 104, p. 467-483, 2011.

[6] Etchepare, M. A.; Raddatz, G.C.; Flores, E.M.M.; Zepka, L.Q.; Jacob-Lopes, E.; Barin, J.S.; Grosso, C.R.F. Effect of resistant starch and chitosan on survival of Lactobacillus acidophilus microencapsulated with sodium alginate. LWTFood Science and Technology, v. 65, p.511-517, 2016.

[7] Fao/Oms. Food and Agriculture Organization of the United Nations. Guidelines for the Evaluation of Probiotics in Food. London, Ontario, Canada. April 30 and May 1, 2002.

[8] Gadalla, H.H.; Soliman, G.M.; Mohammed, F.A.; El-Sayed, A.M. Development and in vitro/in vivo evaluation of $\mathrm{Zn}$-pectinate microparticles reinforced with chitosan for the colonic delivery of progesterone. Drug delivery, early online, p.1-14, 2015.

[9] Martin, M.S.; Lara-Villoslada, F.; Ruiz, M.A.; Morales, M.E. Microencapsulation of bacteria: A review of different technologies and their impact on the probiotic effects. Innovative Food Science and Emerging Technologies, v. 27, p. $15-25,2015$.

[10] Mukai Corrêa, R. Produção de micropartículas por gelificação iônica para alimentação de larvas de peixe: Estudos em Sistema-Modelo com inclusão de micropartículas lipídicas ou emulsão lipídica e Testes in vivo. 2008.177 p. Tese (Doutorado em Alimentos e Nutrição) - Universidade Estadual de Campinas, Campinas, 2008.

[11] Oliveira, A. C.; Moretti, T.S.; Boschini, C.; Baliero, J.C.C; Freitas, L.A.P.; Freitas, O.; Fávaro-Trindade, C.S. Stability of microencapsulated B. lactis (BI 01) and L. acidophilus (LAC 4) by complex coacervation followed by spray drying. Journal of Microencapsulation, London, v. 24, n. 7, p. 685-693, 2007. 
[12] Rodrigues, J. B.; Leitão, N.J.; Chaves, K.S.; Gigante, M.L.; Portella, M.C.; Grosso, C.R.F. High protein microparticles produced by ionic gelation containing Lactobacillus acidophilus for feeding pacu larvae. Food Research International, v. 63, p. 25-32, 2014.

[13] Souza, F.N.; Gebara, C.; Ribeiro, M.C.E.; Chaves, K.S.; Gigante, M.L.; Grosso, C.R.F. et al. Production and characterization of microparticles containing pectin and whey proteins. Food Research International v. 49 , p. $560-$ 566, 2012. 


\section{Capítulo 10}

\section{Transesterificação de óleo residual de fritura de couro suíno desidratado}

\section{Artur Faria Gonçalves \\ Osmar Caôn Filho \\ Tiago Sartorelli Prato}

Resumo: Considerado como um país privilegiado por possuir uma grande biodiversidade o Brasil é rico em plantas oleaginosas que em grande maioria, são restringidas a fins alimentícios. Com a necessidade da humanidade em diminuir suas ações prejudiciais ao meio ambiente, vem se promovendo uma tendência em substituir o uso de combustíveis fosseis pelos combustíveis renováveis. 0 biodiesel é um combustível de fonte natural utilizado em motores de ciclo diesel e destaca-se como uma alternativa aos combustíveis derivados de petróleo. 0 objetivo deste trabalho apresentar uma opção de reaproveitamento do óleo residual de fritura de couro suíno desidratado através do processo de transesterificação, utilizando blends de metanol e etanol, e verificando assim sua rentabilidade. Os experimentos foram realizados em escala laboratorial, e os resultados demonstram um maior rendimento nas condições que se utilizou $100 \%$ metanol em sua mistura de alcóxido, com um rendimento médio de 75,35\% em volume de biodiesel produzido.

Palavras-chave: Biodiesel. Transesterificação. Óleo residual. 


\section{INTRODUÇÃO}

O Brasil é considerado pelo mundo como um país privilegiado, possuindo uma grande biodiversidade e sendo muito rico em plantas oleaginosas, cujas culturas, em sua grande maioria, são restringidas a fins alimentícios. Existe um grande potencial a ser explorado, tanto em relação ao rendimento energético de culturas temporárias e ininterruptas, como em relação ao reaproveitamento energético do óleo residual resultante da alimentação, o foco deste estudo.

Com a indispensabilidade da humanidade em subtrair seus níveis de emissões atmosféricas e diminuir suas ações prejudiciais ao meio ambiente, tem acarretado a uma predisposição crescente em trocar combustíveis fósseis pelos conhecidos biocombustíveis, especialmente, no setor de transportes (RUSCHEL, 2014).

A frente da necessidade de se buscar alternativas energéticas para favorecer um desenvolvimento sustentável e uma melhoria da qualidade do ar, do solo e das águas, a evolução tecnológica e a estabilidade dos patrimônios naturais estão unidas em um mesmo caminho crescente para favorecer melhores condições do meio ambiente às próximas gerações (GONTIJO, 2011). Porém, o aumento da frota de automóveis nos dias atuais contribui substancialmente, em conjunto com as queimadas, para o acréscimo das emissões de dióxido de carbono (CO2), enxofre e outros, adiante de materiais particulados que geralmente não são levados em deferência.

0 biodiesel é um combustível de fonte natural usado em motores de ciclo diesel, sintetizado através de fontes renováveis, que segue as especificações da Associação Nacional do Petróleo e a resolução ANP n ${ }^{\circ}$ $7 / 2008$, onde o processo de transesterificação deve ser completo, isto é, sem a presença de ésteres de glicerol residuais, com alta pureza, sem traços de glicerina, catalisador e excedentes de álcool da reação, além de ter que respeitar as rigorosas análises (ANP, RESOLUÇ̃̃O ANP № 7, DE 19.3.2008 - DOU 20.3.2008 s.d.). Sobre uma definição mais desenvolvida o biodiesel é um combustível renovável derivado de diversas espécies de culturas oleaginosas, dentre elas a canola, a mamona, o dendê, o amendoim, o girassol, a soja e o algodão, e também matérias primas de origem animal, como o sebo bovino e a gordura suína, que similarmente podem ser utilizadas na sintetização do biodiesel (MENEGHETTI, 2013).

Há alguns anos estão sendo realizadas experiências com combustíveis alternativos, demonstrando a preocupação de pesquisadores, governos e sociedade em geral com o ocasional esgotamento das reservas petrolíferas e com a questão ambiental, devido à emissões de hidrocarbonetos poliaromáticos (PAH) ,emissões de enxofre, (que causam impactos na saúde pública e no ambiente pelas chuvas ácidas), além do aumento da concentração na atmosfera de gases do efeito estufa como o dióxido de carbono e consequente aquecimento global (CANDEIA, 2008).

As sujidades e poluições que emanam do consumo dos derivados de petróleo resultam em consequentes emissões de partículas manométricas que, no caso de ocorrer inalação pelos seres humanos, não conseguem ser expulsas dos pulmões (SUAREZ et al., 2007) . 0 maior número de estudos sobre impacto ambiental em associação à produção de biocombustíveis concentra-se na determinação da redução na emissão de Gases do Efeito Estufa (GEE) pela substituição de um combustível de origem fóssil por um de origem renovável (RATHMANN et al., 2006).

Atualmente, o uso dos óleos vegetais como combustíveis podem parecer irrelevantes, porém tais podem no decorrer do tempo podem ser tão significantes quanto o petróleo (MENEGHETTI, 2013). Destacando-se como uma alternativa aos combustíveis derivados do petróleo, o biodiesel pode ser usado em carros ou em quaisquer outros motores que dependam da ignição com diesel, porém se sobressaindo como um combustível que emite menos poluentes que o diesel. A aplicação do biodiesel como combustível denota várias vantagens na diminuição das emissões de Gases do Efeito Estufa (GEE), pois auxilia a diminuição qualitativa e quantitativa dos níveis de poluição ambiental, ao substituir o óleo diesel (CARRILHO, 2001).

0 consumo do biodiesel contribui para a redução de 78\% (setenta e oito por cento) de dióxido de carbono, 98\% (noventa e oito por cento) de enxofre e 53\% (cinquenta e três por cento) de monóxido de carbono, por ser obtido de um processo sustentável podendo se utilizar matérias-primas vegetais renováveis tendo efeito positivo sobre o ciclo do carbono, possibilitando a quantificação dos "créditos ambientais", que é a diferença entre o $\mathrm{CO} 2$ que gera combustão do biodiesel e o que se fixa na plantação da matéria-prima, se essa for espécie perene (PENIDO, 2005).

Outra vantagem notória de se utilizar o biodiesel é a ausência de enxofre e compostos aromáticos, logo, nos propicia a uma combustão limpa, e sem a formação de SO2 (gás que provoca a chuva ácida), e de compostos cancerígenos (hidrocarbonetos policíclicos aromáticos) (ZAGONEL, 2000). De forma usual, o mesmo possui número de cetano elevado ( padrão qualitativo da combustão dos combustíveis diesel; esse 
índice é pertencente a velocidade de ignição, que corresponde ao período entre o início da injeção de combustível e o início da combustão) e consequentemente auto poder de combustão, e, esta condição é reflexiva de maneira especial na partida a frio, no ruído do motor e no gradiente de pressão nos motores a diesel (RATHMANN et al., 2006).

Dispõe taxa média de oxigênio em torno de 11\% e composição química homogênea, proporcionando uma combustão mais eficaz, completa, além de lançar menor teor de resíduos para a atmosfera; tem ponto de fulgor mais elevado quando comparado ao diesel convencional, de maneira que, em condições normais de transporte, manuseio e armazenamento, não é inflamável, adequando uma segurança maior (BOMTEMPO, 2010). Quando usado em maior proporção expressa melhora na lubrificação do motor, proporcionando maior longevidade do mesmo e seus entornos, além do mais é biodegradável, e não tóxico.

Para a produção de biodiesel, o processo mais utilizado nos dias de hoje é a transesterificação, onde por meio de tal reação é realizável a separação da glicerina dos óleos vegetais ou gorduras animais. As moléculas em questão são formadas por três ésteres ligados a uma molécula de glicerina, isto é, são triglicerídeos. 0 método inicia-se adicionando ao óleo ou gordura, um álcool simples, podendo ser metanol, etanol, propanol, butanol e catalisadores que podem ser ácidos, básicos ou enzimáticos com a finalidade de se acelerar a reação. Neste método, a glicerina é separada do óleo por decantação, atribuindo ao óleo menor viscosidade. A sintetização do biodiesel ocorre como na Figura 1 abaixo:

Figura 1: Reação de transesterificação por meio de um álcool e catalisador.

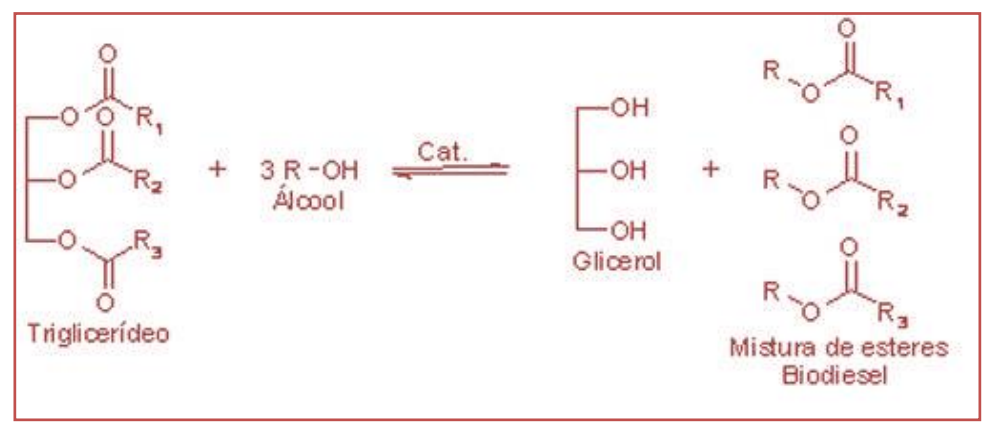

Fonte: (SILVA, 2009).

Em síntese, após ocorrer à reação de transesterificação se obtém a glicerina e o biodiesel, um combustível renovável e alternativo.

Em países como Argentina, Estados Unidos, Malásia, Alemanha, França e Itália atualmente, já produzem biodiesel comercialmente, estimulando o desenvolvimento da escala industrial. Estão sendo realizadas experiências com combustíveis alternativos, demonstrando a preocupação de pesquisadores, governos e sociedade em geral com o ocasional esgotamento das reservas petrolíferas e com a questão ambiental, devido à liberação de dióxido de carbono na atmosfera, que vem provocando o efeito estufa e consequente aquecimento global (RATHMANN et al., 2006). As combinações entre o biodiesel e o diesel mineral são conhecidas pela letra $\mathrm{B}$, em conjunto com o número que corresponde à quantidade de biodiesel na mistura, por exemplo, se uma mistura tem 5\% de biodiesel é chamada de B5, se tem $20 \%$ de biodiesel é B20. Desde $1^{\text {o }}$ de novembro de 2014, o óleo diesel comercializado em todo o Brasil contém 7\% de biodiesel, esta determinação foi estabelecida pelo Conselho Nacional de Política Energética (CNPE), que incrementou de 5\% para 7\% o percentual obrigatório de mistura de biodiesel ao óleo diesel (SUAREZ et al., 2007) . O contínuo avanço do percentual de adição de biodiesel ao diesel demonstra o sucesso do Programa Nacional de Produção e Uso do Biodiesel e da bagagem acumulada pelo Brasil na produção e no uso em larga escala de biocombustíveis. 0 uso do biodiesel puro ainda esta em teste, se for empregado apenas biodiesel sem combinar com o diesel mineral, irá se denominar B100 (PAULILLO et al., 2007).

A realização deste trabalho justifica-se na produção de biodiesel por transesterificação a partir do aproveitamento de óleos residuais de fritura de couro suíno desidratado como uma das possíveis alternativas tanto para redução das emissões de gases poluentes por ser este um combustível limpo, oriundo de fontes renováveis, quanto por apresentar-se como um apelo ambiental ao designar um uso racional deste óleo quando deixado de ser inaproveitável ou descartado de modo incorreto no meio ambiente (HOLANDA, 2004). 


\section{REVISÃO BIBLIOGRÁFICA}

O sistema mais usual para obtenção de biodiesel é a reação de transesterificação, que é uma reação química onde se consegue intercorrer entre um éster e um álcool ou entre um éster e um ácido, constantemente obtendo a formação de um novo éster (RUSCHEL et al., 2014). Atualmente a reação de transesterificação de óleos vegetais ou gordura animal com álcoois encontra-se despertando muito interesse, assim que o principal produto da reação, o éster, tem propriedades iguais às do óleo diesel obtido do petróleo, podendo ser utilizado puro ou adicionado ao diesel fóssil, habitualmente denominado como biodiesel (ANP, 2015). Nesta conjuntura, a palavra "bio" significa ser processado a partir de fontes renováveis de biomassa (óleo de soja, mamona, dendê, girassol, canola) e podendo se incluir no processo o etanol, que no Brasil é obtido mediante processo de fermentação do sumo de cana-de-açúcar (HOLANDA, 2004). Em nosso país a produção do biodiesel é favorável, em função da oportunidade do cultivo de oleaginosas sem lesionar a produção e oferta de alimentos.

Dentre os inúmeros procedimentos que podem ser empregados para sintetizar os ésteres, um bom modelo é a reação de esterificação de Fischer (1895), em que, sob calefação, um ácido carboxílico reage com um álcool (produzindo éster e água). Esta reação, quando realizada em temperatura ambiente, é lenta, porém a mesma consegue ser acelerada com a aplicação de acaloramento e/ ou acelerador, como de exemplo o ácido sulfúrico (H2SO4) (PENIDO, 2005). Todavia, o éster adquirido consegue reagir com a água, ocorrendo à reação de hidrólise, provocando novamente ácido carboxílico e álcool, contudo, a reação inversa é mais demorada. A reação de hidrólise de um éster em meio básico é nominada saponificação que vêm do latim, sapo = sabão; podendo ser realizada em meio ácido ou básico, por conseguinte dependendo do catalisador e o reagente a ser escolhido para a reação (BOMTEMPO, 2010). A esse modelo de transesterificação foi imputado o termo de alcoolize, tendo como produtos principais o éster e o glicerol. A reação se inicia pela miscigenação do óleo vegetal com um álcool, como de exemplo o metanol ou o etanol, em presença de um catalisador que pode ser um ácido, uma base ou uma enzima. Posteriormente a reação de transesterificação, consegue-se o biodiesel, um biocombustível renovável alternativo, e a glicerina, uma substância de alto valor agregado, muito aproveitável na indústria farmacêutica e de cosméticos.

A importância dada aos ésteres orgânicos provém destas substâncias estimularem grande utilidade decorrente de sua relevância industrial, principalmente nas operações que envolvem emprego de solventes, vernizes, resinas, plastificantes, polímeros, intermediários para a indústria farmacêutica, fragrâncias e essências sintéticas (GONTIJO et al; 2011). Consegue-se citar como exemplos, o acetato de isopentila, em que é empregado como essência de banana, o acetato de benzila comumente utilizado como essência de jasmim, o pentanoato de isopentila que é usado como essência de maçã, o acetato de etila empregado com solvente em diversos materiais e o acetato de butila normalmente utilizado como solvente encontrado no esmalte (CANDEIA, 2008).

Os catalisadores básicos e ácidos mais usados frequentemente vêm sendo os hidróxidos e alcóxidos de sódio ou potássio e os ácidos sulfúrico e clorídrico. Todavia atualmente estuda-se também o processo de hidroesterificação, no qual se permite o uso de qualquer matéria-prima graxa (gordura animal, óleo vegetal, óleo de fritura usado, borras ácidas de refino de óleos vegetais, entre outros) independente da acidez e da umidade que possuem (ZAGONEL, 2000). Este é um grande diferencial, quando comparado ao processo convencional de transesterificação que gera inevitavelmente sabões, afetando o rendimento e dificultando a separação biodiesel/glicerina (CARRILHO, 2001).

Com as recaídas e turbulências no mercado internacional de combustíveis de origem fóssil, aliada às pressões sobre o setor automotivo e dos órgãos ambientais, fez com que o Governo Federal iniciasse um novo empenho em introduzir biocombustíveis na matriz energética nacional e incentivar, em especial, com ações de oficializações de leis como a Lei 11.097 de 13 de janeiro de 2005, que estabelece a obrigatoriedade da adição de um percentual mínimo de biodiesel ao óleo diesel comercializado ao consumidor, em qualquer parte do território nacional (MAPA, 2005). Esse percentual obrigatório era de 5\% durante oito anos após a publicação da referida lei, sucedendo um percentual obrigatório intermediário de $3 \%$ nos próximos três anos após a publicação da mesma, pressupondo um desenvolvimento econômico e social para o país, com a expectativa de reduzir a dependência do diesel (MAPA, 2006).

Muitos projetos de reaproveitamento têm sido criados no Brasil, em que dentre eles destacam-se o aproveitamento dos óleos vegetais usados nos processos de fritura de alimentos por imersão, visto que, grande quantidade de óleo de fritura que é gerado, tem como aproveitamento a produção de sabão, massa de vidraceiro, ração animal, produção de biodiesel e também, boa parte de seu volume é inaproveitado sendo descartado diretamente em redes de esgotos. Este descarte incorreto dos resíduos de óleo vegetal é 
um problema antigo, sabendo-se que cada litro de óleo despejado no esgoto tem capacidade para poluir cerca de um milhão de litros de água, conjuntamente ao ser jogado no esgoto encarece o tratamento dos resíduos em até aproximadamente 46\% (MAPA, 2006).

A presença deste resíduo nos rios cria um bloqueio que atrapalha a entrada de luz e a oxigenação da água, prejudicando assim, a base da cadeia alimentar aquática e ajudando para o acontecimento de enchentes. Além do que, a decomposição do óleo de cozinha emite metano na atmosfera, um tipo de gás inodoro, incolor, que em conjunto ao ar atmosférico transforma-se em uma mistura de alto teor explosivo (BOMTEMPO, 2010)

O objetivo deste trabalho é demonstrar uma opção de reaproveitamento de óleo residual de fritura de couro suíno desidratado gerado na empresa Silvano Gonçalves Alimentos-ME, situada na cidade de Fernandópolis -SP, São Paulo, na Rua Paraíba número 280, bairro Vila São José.

\section{MATERIAIS E MÉTODOS}

A metodologia aplicada foi baseada e adaptada do trabalho de Batista e colaboradores (2009), sendo executada nos laboratórios de Química da Fundação Educacional de Fernandópolis - FEF, nos períodos de Setembro a Outubro de 2015. A técnica é baseada no processo de transesterificação do óleo residual sob catálise alcalina, para obtenção de biodiesel através das rotas metílicas e etílicas, por meio de blend de metanol e etanol, verificando assim como que os diferentes blends metanol e etanol afetam na rentabilidade da reação. Os experimentos foram realizados em triplicatas e diferentes proporções de álcool metílico e etílico, totalizando dezoito experimentos de síntese de biodiesel em diferentes porções de metanol e etanol. No total foram utilizados 9,5 litros de óleo residual de fritura de couro suíno desidratado, doados da empresa NILO Alimentos, 3,6 litros de metanol e etanol, uma média de 72 gramas de Hidróxido de sódio, $82 \mathrm{ml}$ de ácido acético e $90 \mathrm{ml}$ de glicerina livre. As figuras a seguir mostram a sequência de obtenção do biodiesel.

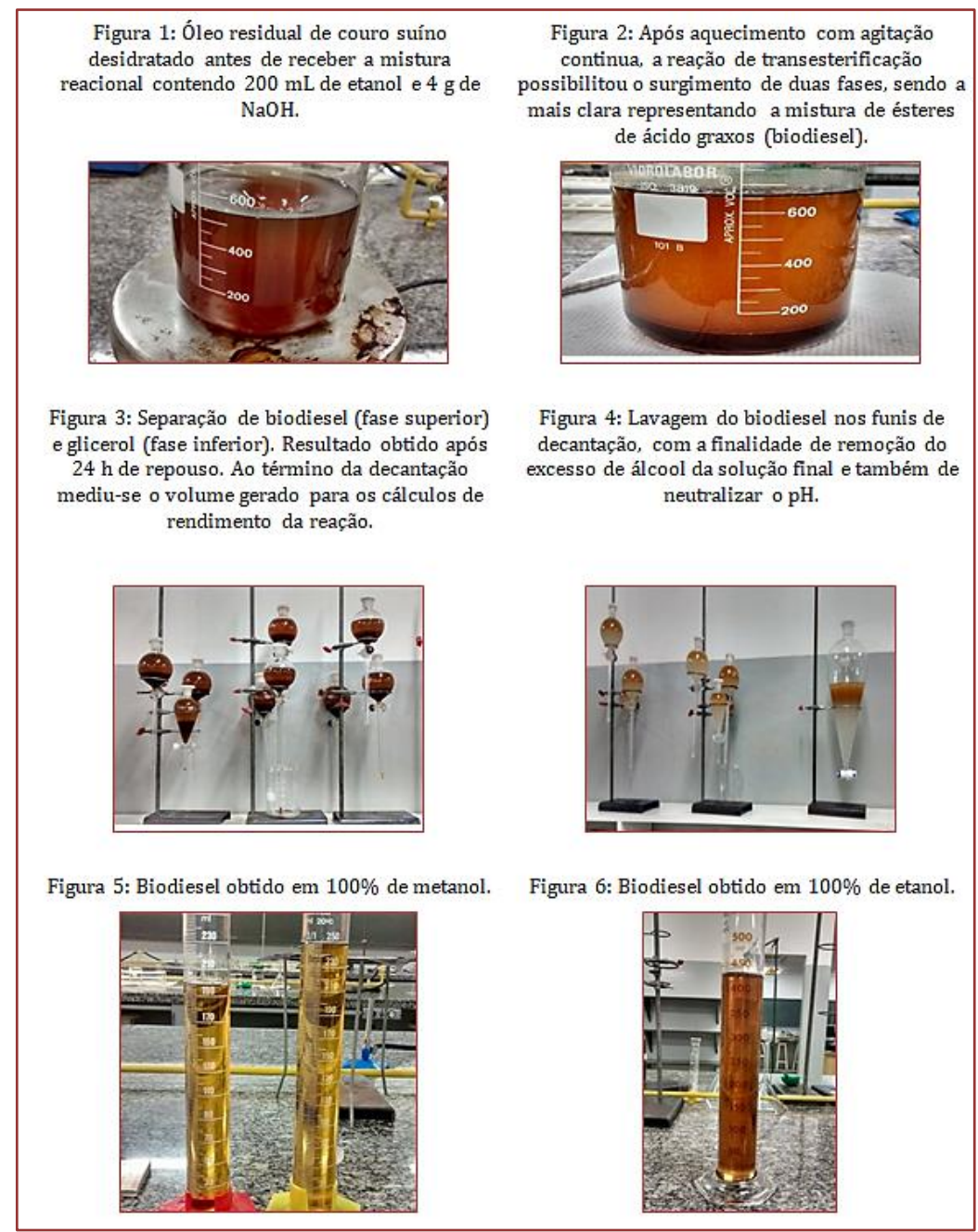




\section{RESULTADOS E DISCUSSÃO}

Os experimentos foram realizados em triplicata a $25 \mathrm{oC}$ nas seguintes condições: $500 \mathrm{ml}$ de óleo residual de couro suíno desidratado, diferentes proporções etanol/metanol e $4 \mathrm{~g}$ de $\mathrm{NaOH}$. A lavagem do biodiesel foi realizadas em uma mistura de $495 \mathrm{~mL}$ de água deionizada e $5 \mathrm{~mL}$ de ácido acético glacial. Os resultados e seus rendimentos são apresentados na tabela a seguir:

\begin{tabular}{|c|c|c|}
\hline Blend alcoólico & vol. metanol/vol etanol & $\begin{array}{l}\text { Rendimento de obtenção do } \\
\text { biodiesel }\end{array}$ \\
\hline 100\% Metanol & $200 \mathrm{~mL} / 0 \mathrm{~mL}$ & $75,35 \%$ \\
\hline $80 \%$ Metanol / 20\% Etanol & $160 \mathrm{~mL} / 40 \mathrm{~mL}$ & $69,40 \%$ \\
\hline $60 \%$ Metanol / 40\% Etanol & $120 \mathrm{~mL} / 80 \mathrm{~mL}$ & $66,20 \%$ \\
\hline $40 \%$ Metanol / 60\% Etanol & $80 \mathrm{~mL} / 120 \mathrm{~mL}$ & $58,60 \%$ \\
\hline $20 \%$ Metanol / 80\% Etanol & $40 \mathrm{~mL} / 160 \mathrm{~mL}$ & $60,00 \%$ \\
\hline $100 \%$ Etanol & $0 \mathrm{~mL} / 200 \mathrm{~mL}$ & $57,90 \%$ \\
\hline
\end{tabular}

Os resultados demonstram os maiores rendimentos na obtenção do biodiesel nos experimentos com alcóxido $100 \%$ metanol em volume e com o blend em $80 \%$ etanol e $20 \%$ metanol. Comportamento este semelhante aos resultados obtidos por Batista e colaboradores (2009), que trabalharam com óleo de soja comum. A discrepância dos valores justifica-se na fonte de origem do óleo e no fato de que utilizamos residual de fritura, onde ocorre uma série de reações químicas, produzindo compostos que afetam as qualidades funcionais, sensoriais e nutricionais dos alimentos. Dentre as principais reações de deterioração encontra-se a hidrólise, a oxidação e polimerização (SILVA, 2011).

\section{CONCLUSÕES}

Diante dos resultados obtidos, conclui se que os objetivos propostos neste trabalho foram alcançados, já que se apresentaram opções viáveis e plausíveis de reaproveitamento para o óleo residual de fritura de couro suíno desidratado gerado na empresa Silvano Gonçalves Alimentos- ME (NILO), e estabelece uma nova importância ao resíduo, uma vez que o resíduo gerado adquire uma finalidade processual e um valor econômico técnico se destinado a empresas que processam resíduos oleicos para biodiesel; já que eram destinados a doações para realização de sabão, a projetos sociais denominados "cata óleo", e outras serventias. Neste mostramos também a viabilidade de sintetização do biodiesel sob a rota $100 \%$ metílica, porém, alguns fatores necessitam ser considerados como a toxidade do metanol e a sua origem provir de fontes fósseis Por outro lado, a sintetização por rotas etílicas necessita da adição de glicerina livre para que se ocorra à decantação na integra, inviabilizando o processo economicamente.

\section{AGRADECIMENTOS}

Agradecemos a empresa Silvano Gonçalves Alimentos- ME (NILO) pela doação do óleo residual de couro suíno desidratado, sem o qual não seria possível a realização desse trabalho e a Fundação Educacional de Fernandópolis FEF, que nos proporcionou sua estrutura laboratorial para a execução dos experimentos.

\section{REFERÊNCIAS}

[1] AGÊNCIA NACIONAL DO PETRÓLEO - ANP (homepage na internet). Disponível em: <http://www.anp.gov.br/> . Acesso em 20 Jul. 2015.

[2] Batista, T. Separação eficiente de glicerol e biodiesel através da utilização de blends de metanol e etanol. 2005. Disponível em:< http://ic.ufabc.edu.br/II_SIC_UFABC/resumos/paper_5_173.pdf>. Acesso em 28 out. 2015.

[3] Bomtempo, J. V. O futuro dos biocombustíveis. 2010. Disponível em:< https://infopetro.wordpress.com/2010/03/29/o-futuro-dos-biocombustiveis-i/> . Acesso em 19 Ago. 2015

[4] Candeia, R. Biodiesel de Soja: Síntese, Degradação e Misturas Binárias. 2008. 132f. Tese de Doutorado (Departamento de Química). Universidade Federal da Paraíba, João Pessoa, 2008 
[5] Carrilho, E.; Tavares, M.C.H.; Lanças, F.M. Fluídos supercríticos em química analítica. I. Cromatografia com fluído supercrítico: conceitos termodinâmicos. Química Nova, vol. 24, n. 4, p. 509-515, 2001. Disponível em < http://www.scielo.br/pdf/qn/v24n4/a12v24n4.pdf>. Acesso em 16 Set. 2015.

[6] Gontijo, T. S.; Fernandes, E. A., Saraiva, Balduino M. Análise da volatilidade do retorno da commodity dendê: 1980-2008. Rev. Econ. Sociol. Rural, Brasília , v. 49, n. 4, p.857-874, dez. 2011. Disponível em:<http://www.scielo.br/scielo.php?script=sci_arttext\&pid=S0103-20032011000400003\&lng=pt\&nrm=iso >. acesso em 12 set. 2015.

[7] Holanda, A. "Biodiesel e inclusão sócial. Brasília: Câmara dos Deputados, Coordenação de Publicações, 2004. Disponível em <http://www2.camara.leg.br/a-camara/altosestudos/pdf/biodiesel-e-inclusao-social/biodiesel-einclusao-social> Acesso em 08 Ago. 2015.

[8] Meneghetti, S. M. P.;Meneghetti, M. R.; Brito, Y. C.Sítio do Programa Nacional de Produção e Uso do Biodiesel. A Reação de Transesterificação, Algumas Aplicações e Obtenção de Biodiesel. 2013 Disponível em:< http://www.mme.gov.br/programas/biodiesel/menu/programa/historico.html> .Acesso em: 10 Ago.2015.

[9] MINISTÉRIO DA AGRICULTURA, PECUÁRIA ABASTECIMENTO, MAPA. Plano Nacional de Agroenergia. 2006. Disponível em: <http://www.agricultura.gov.br> Acesso em 07 Ago. 2015

[10] Paulillo, L. F., Vian C. E. F., Shikida P. F. A., Mello F.T. Álcool combustível e biodiesel no Brasil: quo vadis?. Rev. Econ. Sociol. Rural, Brasília , v. 45, n. 3, p. 531-565, set. 2007. Disponível em <http://www.scielo.br/scielo.php?script=sci_arttext\&pid=S0103-20032007000300001\&lng=pt\&nrm=iso>. Acessos em 01 set. 2015.

[11] Penido, H.R; Biodiesel: debates e propostas. UOL. Teresina, mar. 2005. Disponível em:< http://jus2.uol.com.br/doutrina/texto.asp?id=6702>. Acesso em: 12 Set.2015.

[12] Rathmann, R., Benedetti, O.; Plá, J. A.; Padula, A. D. "Biodiesel: Uma alternativa estratégica na matriz energética $\quad$ brasileira?". $2006 . \quad$ Disponível em http://sottili.xpg.uol.com.br/publicacoes/pdf/IIseminario/sistemas/sistemas_03.pdf > Acesso em 06 de Ago. 2015.

[13] Ruschel C.F.C.; Te Huang C.; Samios D.; Ferrão, M. F.. Análise exploratória aplicada a espectros de reflexão total atenuada no infravermelho com transformada de Fourier (ATR-FTIR) de blendas de biodiesel/diesel. Quím. Nova, São Paulo , v. 37, n. 5, p. 810-815, jun. 2014 . Disponível em <http://www.scielo.br/scielo.php?script=sci_arttext\&pid=S0100-40422014000500009\&lng=pt\&nrm=iso>. acessos em 17 set. 2015 .

[14] Silva, R.A.T. Biodiesel de óleo residual: Produção através da transesterificação por metanólise e etanólise básica, caracterização físico-química e otimização das condições reacionais. 2011. 152p. Tese de doutorado. (Doutor em Química)- Programa Multi-institucional de Doutorado em Química da UFG/UFMS/UFU, Uberlândia, 2011.

[15] Silva, W. As reações químicas do Biodiesel. 2009. Disponível em: < http://portaldoprofessor.mec.gov.br/fichaTecnicaAula.html?aula=6100> Acesso em: 26 out. 2015.

[16] Suarez, P. A. Z.; Meneghetti, S. M. P., Meneghetti, M. R. e Wolf, C. R.. Transformação de triglicerídeos em combustíveis, materiais poliméricos e insumos químicos: algumas aplicações da catálise na oleoquímica. Quím. Nova, São Paulo , v. 30, n. 3, p. 667-676, jun. 2007 Disponível em <http://www.scielo.br/scielo.php?script=sci_arttext\&pid=S0100-40422007000300028\&lng=pt\&nrm=is> Acesso em 12 Set. 2015

[17] Zagonel, G. F.; Ramos, L. P.; Neto, P. R. C.; Rossi, L. F. S. Produção de Biocombustível Alternativo ao Óleo Diesel, Através da Transesterificação de Óleo de Soja Usado em Frituras. Química Nova, 23(4):531-537, 2000. Disponível em< http://www.scielo.br/pdf/qn/v23n4/2654.pdf>. Acesso em 17 Set. 2015. 


\section{Capítulo 11}

\section{Kefir Vinegar: Assessment of metabolic activity of Kefir by Biospeckle Laser}

\section{Karina Teixeira Magalhães Guedes}

Roberta Oliveira Viana

Roberto Alves Braga Jr.

Disney Ribeiro Dias

Rosane Freitas Schwan

Itaciara Larroza Nunes

Abstract: The aim of this study was to develop a kefir apple-based vinegar and study this fermentation process using new methodology with Biospeckle Laser biosensor. Brazilian kefir grains were inoculated in apple must for vinegar production. Kefir grains were analyzed daily using Biospeckle Laser and the biological activity value obtained was 14.21. The biological activity of the kefir grains decreased in the early days of the fermentation process. The decrease in biological activity persisted until the third day of fermentation. On the fourth day the biological activity of kefir grains in apple must increased to 11.51 . On the last day of fermentation the biological activity of kefir grains decreased to value 7.12 (alcoholic fermentation) and $\sim 6.77$ (acetic fermentation). The results showed that kefir grains were able to utilize apple must as substrate and produce ethanol, and acetic acid. The yield of acetic acid in the kefir vinegars was $\sim 79 \%$. The acetic acid concentration was $\sim 41.00 \mathrm{gL}^{-1}$, reaching the required standard for the Brazilian legislation accepts it as vinegar (4.0\% acetic acid). Kefir vinegar showed good acceptance in the sensory analysis. The methodology to measure the metabolic activity of kefir grains by Biospeckle Laser biosensor facilitates the microbiological control over a fermentation process.

Index Terms : chemical analysis, acetic acid, apple, biospeckle. 


\section{INTRODUCTION}

Kefir is a culture employed to produce beverages, such as the traditional Russian beverage also named "kefir" which is from milk, and has low alcohol contente (Simova et al., 2002; Magalhães et al., 2010, 2011; Magalhães-Guedes et al., 2018). The kefir is a mixed culture of various yeast species of the genus Kluyveromyces, Candida, Saccharomyces and lactic acid from bacteria of the genus Lactobacillus combined in a matrix of proteins and polysaccharide 'kefiran', which are formed during cell growth under aerobic conditions (Simova et al., 2002; Magalhães et al., 2010, 2011; Magalhães-Guedes et al., 2018). The kefir beverage contains vitamins, minerals and essential amino acids that help the body with healing and maintenance functions and contains easily digestible complete proteins (Simova et al., 2002; Magalhães et al., 2010, 2011).

An optical technique with potential use in biological metrology, particularly in biological activity, is the dynamic Laser Speckle, or Biospeckle biosensor, when associated to biological material (Braga et al., 2003; Guedes et al., 2014; Catalano et al., 2019). When a laser beam is scattered by a biological sample, the scattered waves generated in the illuminated sample create the speckle pattern that changes its image in accordance with the changes in the monitored material. Thus, the surface appears to be covered with tiny bright dots that fluctuate in a seemingly random way as for a boiling liquid.

The aim of this study was to develop an apple vinegar-based kefir and study this fermentation process using new method Biospeckle Laser biosensor.

\section{MATERIALS AND METHODS}

Brazilian kefir grains (Stock-culture of the Microbiology laboratory of the Federal University of Lavras, Brazil) were used in the experiments. The apple fruits were obtained from Lavras city market, Minas Gerais State in of Brazil. These apple fruits, which fail to meet the quality standards required for marketing, were washed in clean water to remove residues. The pulp was extracted using an automatic depulping machine (ITAMETAL 0.5 DS, Itabuna, BA, Brazil). The ${ }^{\circ}$ Brix was analysed, and the juice was divided into three $500 \mathrm{~mL}$ Erlenmeyer flasks to start batch fermentation.

\subsection{THE PROCESS OF VINEGAR PRODUCTION}

The initial apple must was inoculated with kefir grains in a proportion of $10 \% \mathrm{w} / \mathrm{v}$. The flasks were incubated statically at a temperature of $28{ }^{\circ} \mathrm{C}$ and fermentation was monitored daily to observe the end of the fermentation (stability of the consumption of sugars - Brix). The fermentation must was filtered by kitassato filters $(0.5 \mu \mathrm{m})$. The kefir grains were recovered. The alcoholic must was used for apple kefir vinegar production. To determine fermentation performance were calculated the substrate conversion factors in ethanol $(\mathrm{Yp} / \mathrm{s})$, substrate conversion in glycerol $(\mathrm{Yg} / \mathrm{s})$, substrate conversion in acetic acid $(\mathrm{Yac} / \mathrm{s})$, ethanol volumetric productivity of ethanol $(\mathrm{Qp})$, biomass productivity $(\mathrm{Px})$ and conversion efficiency (Ef). The total concentration of sugars was calculated considering the conversion for each mole of sucrose (342 g) in $1 \mathrm{~mol}$ of glucose (180 g) and $1 \mathrm{~mol}$ of fructose (180).

The apple fermented must obtained in the previous section were acetified in $500 \mathrm{~mL}$ Erlenmeyer flasks, which were controlled temperature of $28{ }^{\circ} \mathrm{C}$ and agitation of $150 \mathrm{rpm}$. The acetic fermentation was conducted using the following treatments:1. kefir grains 10\% (w/v); 2. kefir grains $20 \%$ (w/v). During acetic fermentation, daily samples were taken ( 6 days) in triplicate for acidity analysis ( $\mathrm{pH}$ meter) and alcohol (alcoholometer). The acetic fermentation was finish on the sixth day when the vinegar presented alcohol content below $1.0 \%(\mathrm{v} / \mathrm{v})$. The yield was calculated as the acetic acid produced in relation to the theoretical yield. The theoretical yield was calculated as the amount of ethanol converted to acetic acid, in which $1.0 \mathrm{~g}$ of ethanol yields $1.304 \mathrm{~g}$ of acetic acid. The kefir apple vinegar was then filtered through diatomaceous earth, bottled and pasteurised at $65{ }^{\circ} \mathrm{C}$ for $20 \mathrm{~min}$. Samples were analysed by optical microscopy (National Optical 131 Microscope) to evaluate the clarity of the vinegar. 


\subsection{ASSESSMENT OF METABOLIC ACTIVITY BY BIOSPECKLE LASER BIOSENSOR}

Daily analysis of kefir grains were done by Biospeckle Laser biosensor to observe the biological activity. The grains of kefir were illuminated by a HeNe laser, wavelength of $632 \mathrm{~nm}$, and $10 \mathrm{~mW}$ power, enlarged by a plane concave lens in order to cover the entire sample. The interference patterns formed on them were captured by a CCD camera $640 \times 486$ pixels, with a shutter speed of $1 / 60 \mathrm{~s}$ and in a rate of $0.08 \mathrm{~s}$ creating a collection of 128 images. The analysis of the images, from the laser illumination, was performed according Guedes et al. (2014).

\subsection{SENSORY EVALUATION}

The sensory evaluation was approved by the Ethics and Research Committee (CEP) of the Federal University of Lavras, Brazil: 1.054.963, April 24/2015. The final vinegar were evaluated in a sensory test. The tasters were asked to indicate how much they liked or disliked each product on a 9-point hedonic scale ( 9 = like extremely; 1 = dislike extremely) according to overall acceptability (Moraes, 1993) by twenty-five untrained tasters, both males and females, 25-35 years of age (students and staff of the Biology Department, Federal University of Lavras, Brazil). The evaluation of the appearance, color and odor attributes were also conducted. Randomised, refrigerated $\left(10^{\circ} \mathrm{C}\right) 10 \mathrm{~mL}$ samples were served in clear, tulip-shaped glasses with a volume of $50 \mathrm{~mL}$. These samples were marked with a three digit random number and covered with Petri dishes.

\subsection{STATISTICAL ANALYSES}

Each fermentation process (alcoholic and acetic) was conducted in triplicate and the mean values \pm standard deviations are reported. The Tukey's test was performed using Statgraphics Plus for Windows 4.1 software (Statistical Graphics Corp. Software - (Free download)) to evaluate the statistical significance (level of $\mathrm{P}<0.05$ ).

\section{RESULTS}

Kefir grains were analyzed daily using Biospeckle Laser biosensor and the biological activity value obtained was 14.21. This value was considered the initial fermentation time $(0 \mathrm{~h})$. The test of homogeneity of the grains of kefir can be seen in Figure 1, where the in Figure 1a the image of the kefir grain is presented with an illustration of a yellow window where the laser was illuminated and the images assembled.

The result of the biological activity test is presented in Figure $1 \mathrm{~b}$ (red window) and Figure 1c. In the alcoholic fermentation the biological activity of the kefir grains decreased in the early days of the fermentation process (Figure 1b). The decrease in biological activity persisted until the third day of fermentation. On the fourth day the biological activity of kefir grains in apple must increased to 11.51 . On the last day of fermentation the biological activity of kefir grains decreased to value 7.12.

The acetic fermentation occurred simultaneously as the alcoholic fermentation. In the acetic fermentation the biological activity of the kefir grains decrease in the early days of the fermentation process for treatment 1 and 2 (Figure 1c). The decrease in biological activity persisted until the third day of fermentation. On the fifth day, the biological activity of kefir grains increased to 8.01 (treatment 1) and 8.79 (treatment 2). On the last day of fermentation the biological activity of kefir grains decreased to 6.36 (treatment 1 ) and 6.77 (treatment 2).

The apple alcoholic must was produced. The fermentation temperature selected was $28^{\circ} \mathrm{C}$ and the kefir grains were chosen as the inoculum for the fermentation process. An inoculum of $10 \%$ kefir inoculum was sufficient because the ethanol concentration at $120 \mathrm{~h}$ of fermentation was approximately $97.0 \mathrm{~g} \mathrm{~L}-1$ $\left(\sim 12.3^{\circ} \mathrm{GL}\right.$ (Gay Lussac)). The $\mathrm{pH}$ value was 3.82 and ${ }^{\circ}$ Brix was 4.37 in the final alcoholic must. The values of the kinetic parameters obtained from the apple alcoholic must are described as ethanol productivity $(\mathrm{Yp} / \mathrm{s}) \mathrm{g}-10.47 \mathrm{~g}$, yield glycerol $(\mathrm{Yg} / \mathrm{s}) 0.05 \mathrm{~g}$ g-1, ethanol yield (qp) $0.37 \mathrm{~g} \mathrm{~L}-1 \mathrm{~h}$ and fermentation efficiency (Ef) $93.12 \%$.

After the alcoholic fermentative process, the alcoholic must was processed as described in the methodology for the subsequent production of apple vinegar. The yield of acetic acid in the kefir vinegars was $\sim 79 \%$. The total acetic acid concentration was $\sim 41.00 \mathrm{gL}-1$, reaching the required standard for the 
Brazilian legislation accepts it as vinegar (4.0\% acetic acid) (Brasil, 2009). The kefir vinegars showed the clear appearance and had a good colour (pale yellow) (Figure 2).

Sensory analyses were conducted to kefir vinegar $(10 \%$ and $20 \%$ of kefir grain inoculum) and the commercial apple vinegar. Using the CATA testing, the vinegars were subjected to sensory evaluation to assess their acceptance and preference. Vinegars at 10\%, 20\% and commercial had good acceptance (scores 7.1, 7.4 and 7.2, respectively). Consumers classified vinegars in "liked slightly". Vinegars were evaluated as "sour, acetic acid, limpid and translucent appearance" (Figure 3). No significant differences observed between all evaluated vinegars. The apple kefir vinegars produced were well accepted by the evaluators ( $95 \%$ of consumers would buy kefir vinegar).

\section{DISCUSSION}

The apple pulp was processed to obtain a fermentable must from which the alcoholic must was produced. The inoculum for the fermentation process (kefir grains) was sufficient because the ethanol concentration at $120 \mathrm{~h}$ of fermentation was approximately 97.0 gL-1 ( 12.3 ${ }^{\circ} \mathrm{GL}$ (Gay Lussac)). These results are comparable to that obtained by Dias et al. (2007) who found a value of 89.5 gL-1 when fermenting cocoa pulp with an initial $22^{\circ} \mathrm{Brix}$. Acetic acid was formed during the fermentation of apple alcoholic must. Acetic acid provides a pleasant taste and inhibits the development of undesirable or pathogenic microorganisms, due to the high acidity.

Kefir grains were also analysed by the Biospeckle Laser biosensor technique. The results presented the activity of the kefir grains during fermentation (Figure 1), where it was possible to observe the sensitivity of the technique to follow the expected activity. The proposed technique is simple, relatively cheap and fast, easy to implement, and requires only a laser and standard digital imaging processing hardware componentes (Guedes et al., 2014). The application of Biospeckle Laser method to the kefir viability detection was one of objectives of this work, but the optical technique could also be applied to characterise the kefir grains in other types of processes. Biospeckle Laser technique showed an efficient tool for monitoring and quantifying biological activity of kefir grains, showing the viability time of these grains in a fermentation process, which demonstrates the technique potential for evaluating and monitoring of kefir grains in production of kefir vinegars in industrial scale.

In our study, we studied a new technology for vinegar production, which was conducted using kefir grains in a submerged culture fermentation process using kefir grains at 10\% inoculum (treatment 1 ) and kefir grains at $20 \%$ inoculum (treatment 2). The acetic acid concentration was $\sim 41.0 \mathrm{~g} \mathrm{~L}-1$ in both treatments. Therefore, the kefir grains culture was found to have efficiently fermented the apple alcoholic must to produce vinegar. The taste of the filtered vinegar was fruity and an nice smell was noted. Various organic acids in vinegar are important for imparting a suitable taste and flavour. The total acetic acid concentration in the apple vinegar produced using kefir grains inoculum was $\sim 41.0 \mathrm{~g} \mathrm{~L}-1$, which is approximately two times the concentration in onion vinegar $(\sim 25.0 \mathrm{~g} \mathrm{~L}-1)$ produced using cell-free of Acetobacter aceti (Simova et al., 2002). The kefir grains were highly satisfactory for acetic fermentation using apple alcoholic must as the medium. This system achieved higher acetic acid productivity than that of fermentations by free cells. Our results indicated that the use of kefir grains might be one of the best fermenting strategies employed to overcome substrate limitation and achieve high product yield.

The period for the oxidation of ethanol to yield acetic acid was $140 \mathrm{~h}$. According to the stoichiometry of reaction that converts ethanol to acetic acid, $1.0 \mathrm{~g}$ of ethanol can provide $1.304 \mathrm{~g}$ of acetic acid. $12 \mathrm{In}$ industries, the conversion of $1.0 \mathrm{~g}$ ethanol to $1.0 \mathrm{~g}$ of acetic acid (yield of $76.6 \%$ ) is considered economic (Dias et al., 2007). The production was favourable, reaching values of $\sim 79.0 \%$ yield. Based on the analyses of the vinegar and the limits required by law (Brasil 2009), the final product of kefir vinegar has an acceptable acetic acid level, of approximately $5.0 \%(\mathrm{w} / \mathrm{v})$, and an ethanol concentration of less than $1.0 \%$ $(\mathrm{v} / \mathrm{v})$. The kefir vinegar proved to be a very promising product.

\section{CONCLUSION}

A new methodology to measure the metabolic activity of kefir grains by Biospeckle Laser biosensor was presented. This fact facilitates the microbiological control over a fermentation process. Kefir vinegar was well accepted by sensory analysis. The technology proposed in this study is significant. The key point for industrial application of the proposed technology is the promotion of fermentation by an immobilised-cell 
biomass (kefir grains) that provides the possibility of eliminating the use of centrifugal separators, which have a high energy demand and require high industrial investment.

\section{ACKNOWLEDGEMENTS}

The authors thank the CAPES and CNPq, for financial support.

\section{REFERENCES}

[1] Braga Jr., R.A.; Dal Fabro, I.M.; Borem, F.M.; Rabelo, G.; Arizaga, R.; Rabal, H.J.; Trivi, M. Assessment of seed viability by laser speckle techniques. Biosystems Engineering, v.86, p.287-294, 2003. http://dx.doi.org/10.1016/j.biosystemseng.2003.08.005.

[2] Brasil, Decreto no 6.871, de 4 de Junho de 2009. Regulamenta a Lei no 8.918, de 14 de julho de 1994, que dispõe sobre a padronização, a classificação, o registro, a inspeção, a produção e a fiscalização de bebidas. Legislação Bebidas. Presidência da República. Disponível em http://www.planalto.gov.br/ccivil_03/_Ato20072010/2009/Decreto/D6871.htm. Acesso em: 12 oct. 2016.

[3] CATALANO, m.d.; RIVERA, F.P.; BRAGA, R.A. Viability of biospeckle laser in mobile devices. Optik, v.183, p.897-905, 2019.

[4] Dias, D.R.; Schwan, R.F.; Freire, E.S.; Serôdio, R. Elaboration of a fruit wine from cocoa (Theobroma cacao L.) pulp.. International Journal of Food Science Technology, v.42, p.319-329, 2007.http://dx.doi.org/10.1111/j.13652621.2006.01226.x.

[5] Guedes, J.D.S.; Magalhães-Guedes, K.T.; Dias, D.R.; Braga-Jr., R.A.; Schwan, R.F. Assessment of biological activity of kefir grains by laser biospeckle technique. African Journal of Microbiology Research, v.28, p.2639-2642, 2014. http://dx.doi.org/10.5897/AJMR2014.6852.

[6] Magalhães, K.T.; Dias, D.R.; Pereira, G.V.M.; Oliveira, J.M.; Domingues, L.; Teixeira, J.Á.; Silva, J.B.A.; Schwan, R.F. Chemical composition and sensory analysis of cheese whey-based beverages using kefir grains as starter culture. International Journal of Food Science Technology, v.46, p.871-878, 2011. http://dx.doi.org/10.1111/j.13652621.2011.02570.x.

[7] Magalhães, K.T.; Pereira, G.V.M.; Schwan, R.F. Microbial communities and chemical changes during fermentation of sugary Brazilian kefir. World Journal of Microbiology and Biotechnology, v.26, p.1241-1250, 2010. http://dx.doi.org/10.1007/s11274-009-0294-X.

[8] MAGALHÃES-GUEDES, K.T.; SOUZA, U.S.; SILVA, M.R.; SANTOS, F.L.; NUNES, I.L. Production of rice cerealbased kefir beverage. African Journal of Biotechnology, v.17, p. 322-327, 2018.

[9] Puerari, C.; Magalhães, K.T.; Schwan, R.F. New cocoa pulp-based kefir beverages: Microbiological, chemical composition and sensory analysis. Food Research International, v.48, p.634-640, 2012. http://dx.doi.org/10.1016/j.foodres.2012.06.005.

[10] Moraes, M.A.C. Métodos para avaliação sensorial de alimentos (8. ed.). Unicamp, Campinas: Brazil, 1993, 93p.

[11] Simova, E.; Beshkova, D.; Angelov, A.; Hristozova, T.S.; Frengova, G.; Spasov, Z. Lactic acid bacteria and yeasts in kefir grains and kefir made from them. Journal of Industrial Microbiology and Biotechnology, v.28, p.1-6, 2002. http://dx.doi.org/10.1038/sj/jim/7000186. 
Figure 1. Biological activity of kefir grains by Biospeckle Laser technique. (a) Kefir grains and image formed by Biospeckle Laser. (b) Alcoholic fermentation (凶). (c) Acetic fermentation, ( $\square$ ) 10\% kefir inoculum, ( $\square$ ) 20\% kefir inoculum.
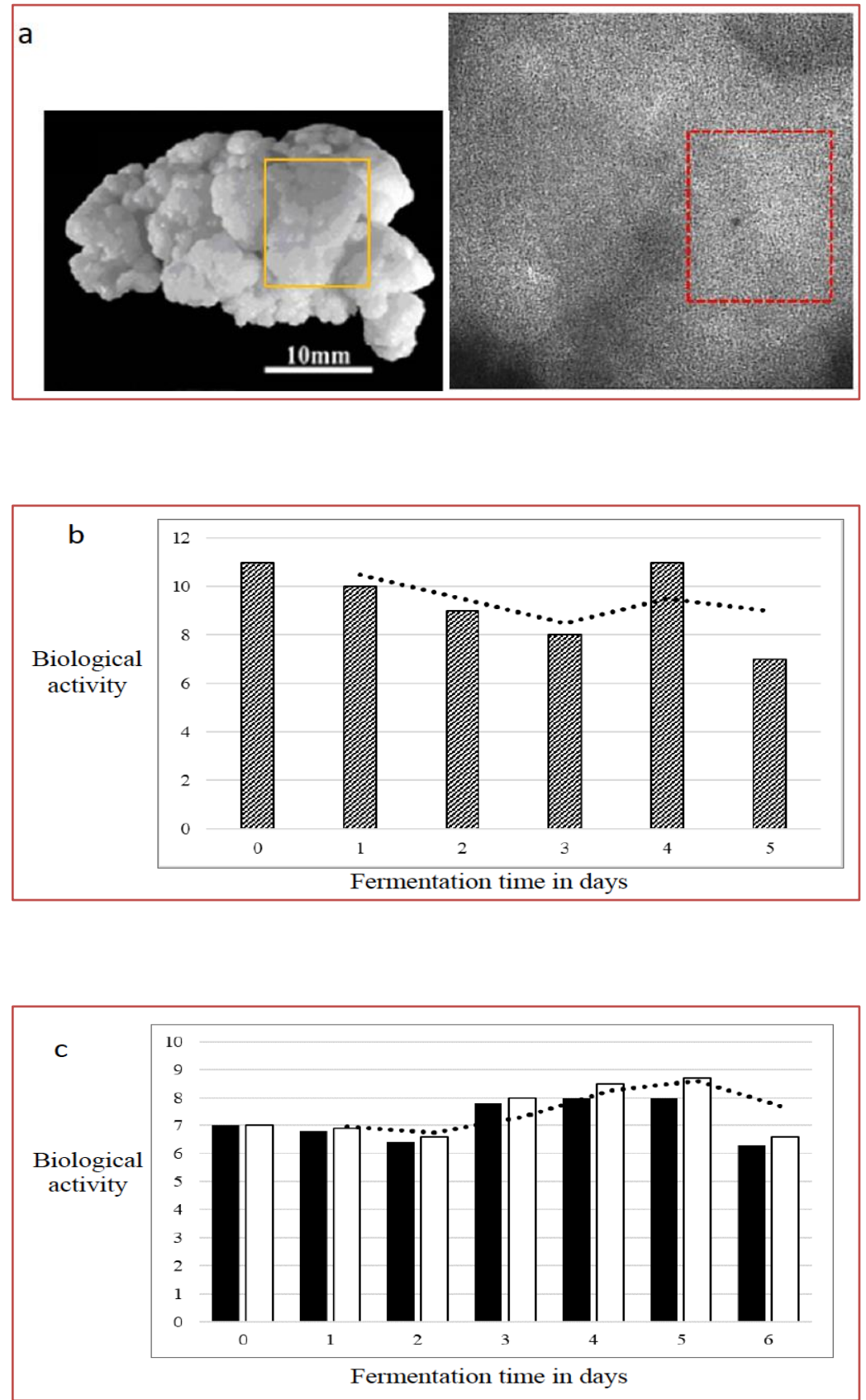
Figure 2. Appearance of kefir vinegar.

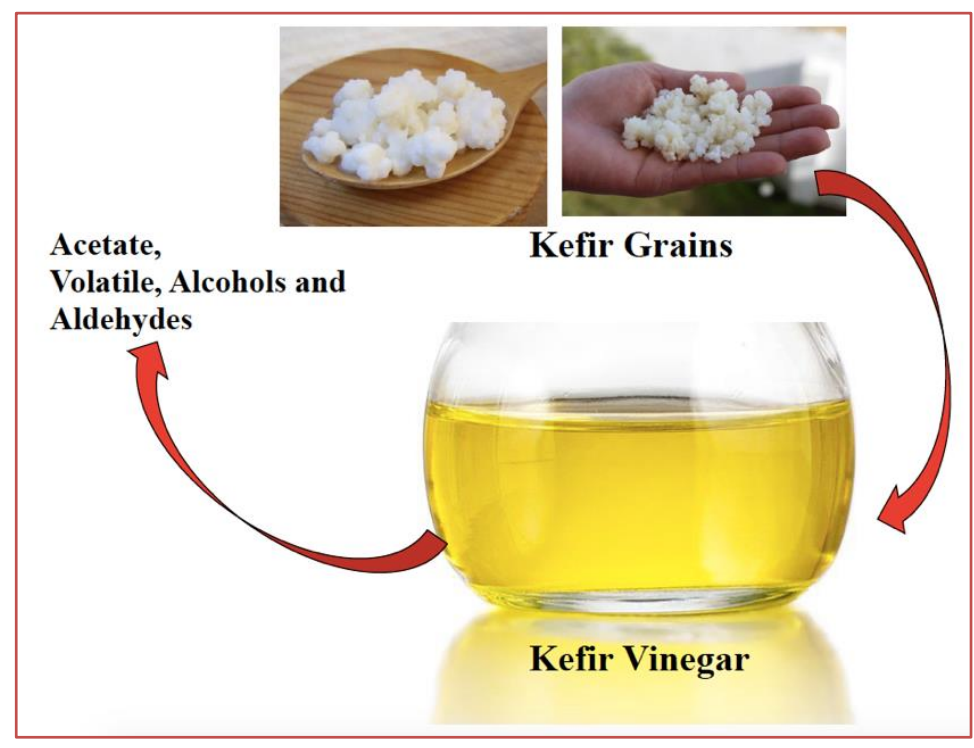

Figure 3. Kefir vinegar sensory analysis.

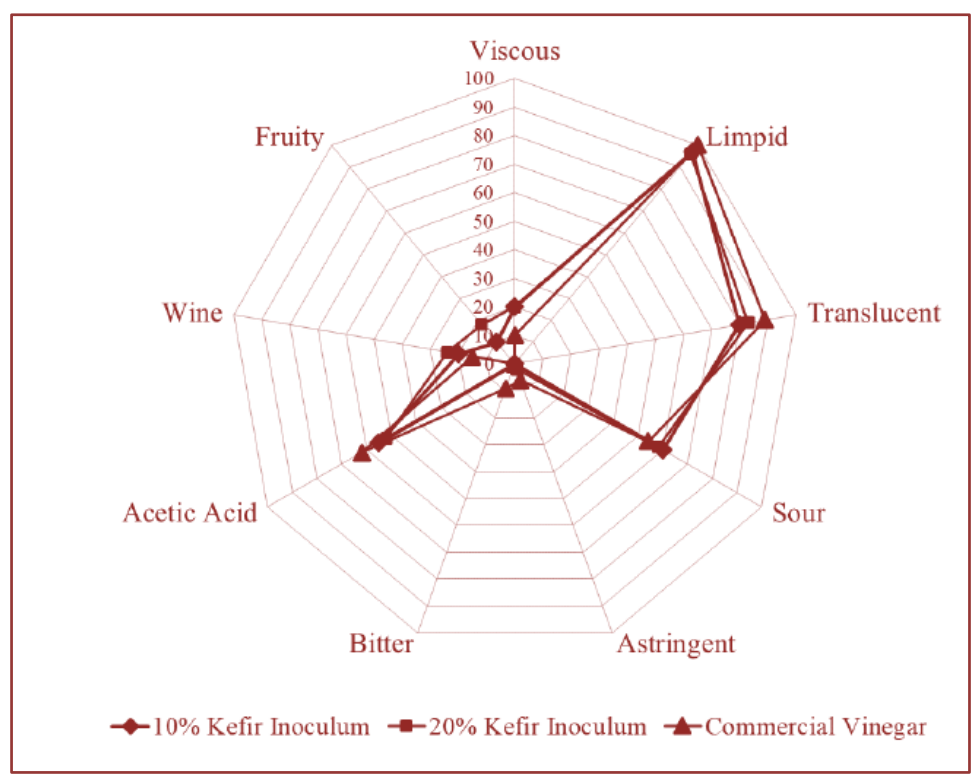




\section{Capítulo 12}

Produção de banana-passa obtida por processos combinados de desidratação osmótica e secagem convectiva

\section{Pablícia Oliveia Galdino}

Bruno Henrique da Silva Melo

Júlia Mendes de Lima

Ângela Maria Santiago

Plúvia Oliveira Galdino

Resumo: 0 objetivo deste trabalho foi produzir banana-passa, cv. prata, através de processos combinados de desidratação osmótica e secagem convectiva. A desidratação osmótica branda foi realizada a $70^{\circ} \mathrm{C}$ a $40{ }^{\circ} \mathrm{Brix}$ e a secagem convectiva em estufa com circulação de ar nas temperaturas de 50, 60 e $70{ }^{\circ} \mathrm{C}$ a qual foi feito a cinética de secagem até massa constante. As fatias de bananas-passa foram caracterizadas segundo o $\mathrm{pH}$, sólidos solúveis, teor de água, sólidos totais, acidez, cor e atividade de água. As amostras foram submetidas à análise sensorial através do teste de aceitação. Todos os parâmetros físico-químicos da banana-passa diferiram estatisticamente entre si, exceto a acidez e a intensidade de vermelho, comprovando que a temperatura influenciou no processo de secagem. Os resultados da análise sensorial apontou que, a maior aceitabilidade foi para o produto na temperatura de $60^{\circ} \mathrm{C}$, devido ao seu excelente sabor e odor.

Palavras-Chave: banana-passa; caracterização, desidratação osmótica. 


\section{INTRODUÇÃO}

A banana é uma das frutas mais populares do mundo. Consumida em todas as regiões do globo, é a fruta símbolo dos países tropicais. Além do sabor, são vários os atrativos nutricionais de estímulo ao seu consumo, é rica em vitaminas A e C, além de fibras e potássio (Sena, 2011). A mesma constitui importante fonte de alimento, podendo ser utilizada verde ou madura, crua ou processada (cozida, frita, assada e industrializada) (Borges et al, 2015).

0 processo de secagem, pelo fato de envolver temperaturas consideravelmente altas para as frutas, por um longo período, causa alterações na composição dos alimentos, perda de nutrientes e modificações bastante significativas na sua estrutura e cor. Muitos autores têm sugerido a utilização da desidratação osmótica como pré-tratamento para a secagem, por se mostrar como processo eficiente para a melhora da qualidade do produto final, diminuindo a perda de nutrientes voláteis e sensíveis a altas temperaturas durante a secagem, resultando também na obtenção de uma textura mais próxima do produto fresco (Mastrantonio et al., 2006).

Essa combinação de métodos pode produzir diversos produtos industrializados a partir da banana, como é o caso da banana-passa. Considerando que o Brasil é um grande produtor de banana, a possibilidade de exploração dessa fruta com fins comerciais é sempre uma grande perspectiva para o produtor. Entretanto, como toda fruta tem um prazo definido para aproveitamento in natura, é crescente o interesse dos produtores por tecnologias que permitam a obtenção da banana com maior prazo de validade (Silva, 2009).

\section{MATERIAIS E METÓDOS}

O trabalho foi conduzido no Laboratório de Análise de Qualidade da Produção Vegetal - LAQPV, pertencente ao Departamento de Agrárias e Exatas da Universidade Estadual da Paraíba e no Laboratório de Armazenamento e Processamento de Produtos Agrícolas - LAPPA, pertencente à Unidade Acadêmica de Engenharia Agrícola da Universidade Federal de Campina Grande.

Os frutos da banana e o açúcar utilizado no preparo da solução de sacarose foram adquiridos no comércio local de Catolé do Rocha, Paraíba, e foram selecionados de acordo com o grau de maturação de 20 a $22^{\circ} \mathrm{Brix}$. As frutas foram selecionadas e submetidas à pré-lavagem com água corrente, após este processo foram lavadas com solução hipoclorito de sódio a $100 \mathrm{ppm}$, posteriormente foram enxaguadas para retirar o excesso da solução.

Os frutos da banana, foram descascados manualmente com auxílio de uma faca de aço inoxidável e cortadas longitudinalmente, ao meio, em fatias de $2 \mathrm{~cm}$ de espessura. Esta parte foi fatiada em $8 \mathrm{~cm}$ de comprimento e altura $2 \mathrm{~cm}$ e colocadas em bandejas de arame galvanizado de $10 \mathrm{~cm}$ de largura utilizadas no secador.

A seguir, os frutos passaram por uma desidratação osmótica branda, por imersão em solução de sacarose, preparada com água destilada e sacarose comercial, com concentração de $40^{\circ} \mathrm{Brix}$, à temperatura de $70^{\circ} \mathrm{C}$, por 5 minutos. Após essa etapa do processo, foram dispostos em bandejas e desidratados em estufa com circulação forçada de ar quente nas temperaturas de processo $\left(50,60\right.$ e $\left.70{ }^{\circ} \mathrm{C}\right)$, até teor de água final entre $20-25 \% \pm 1 \%$. As fatias de banana-passa foram caracterizadas quanto aos seguintes parâmetros físicoquímicos: $\mathrm{pH}$, acidez total titulável, sólidos solúveis totais ( ${ }^{\circ}$ Brix), teor de água, sólidos totais, cor e atividade de água, onde os procedimentos foram realizados em triplicata. Posteriormente foi realizado o estudo da cinética de secagem nas temperaturas citadas até massa constante.

A determinação do $\mathrm{pH}$, acidez total titulável, teor de sólidos solúveis totais (oBrix), teores de água e sólidos totais foram determinados de acordo com as Normas Analíticas do Instituto Adolfo Lutz (Brasil, 2005); os parâmetros de cor da banana-passa foi determinada utilizando-se o espectrofotômetro Mini Scan Hunter Lab XE Plus; a atividade de água foi determinada diretamente em equipamento Aqualab 3TE, da Decagon Devices a $25^{\circ} \mathrm{C}$. Na avaliação sensorial, aplicou-se o teste de aceitação para os parâmetros cor, aparência, odor e sabor, utilizando escala hedônica estruturada de nove pontos $(1=$ gostei muitíssimo a 9 = desgostei muitíssimo) para avaliar a aceitabilidade geral da banana-passa. Na ficha, apresentou-se espaço destinado para comentários sobre os produtos. Todas as fichas para análise sensorial seguiu a metodologia das Normas Analíticas do Instituto Adolfo Lutz (Brasil, 2005).

Para a análise estatística dos dados obtidos utilizou-se o programa computacional ASSISTAT versão 7.5 Beta (SILVA e AZEVEDO, 2006). Utilizou-se o delineamento inteiramente casualizado ( $3 \times 3)$ com 3 
temperaturas e 3 repetições. Para a comparação entre médias foi utilizado a nível de 5\% de probabilidade o teste de Tukey.

\section{RESULTADOS E DISCUSSÃO}

\subsection{CARACTERIZAÇÃO FÍSICO-QUÍMICA DA BANANA-PASSA}

A Tabela 1 exibe os resultados da caracterização físico-química das fatias de bananas-passa em diferentes temperaturas de secagem.

Tabela 1 - Caracterização físico-química das fatias de bananas-passa em diferentes temperaturas

\begin{tabular}{|c|c|c|c|}
\hline \multirow{2}{*}{ Parâmetros } & \multicolumn{3}{|c|}{ Média e desvio padrão } \\
\hline & $50^{\circ} \mathrm{C}$ & $60^{\circ} \mathrm{C}$ & $70{ }^{\circ} \mathrm{C}$ \\
\hline $\mathrm{pH}$ & $4,63 \mathrm{a} \pm 0,032 \mathrm{~b}$ & $4,70 \pm 0,020 \mathrm{a}$ & $4,72 \pm 0,020 \mathrm{c}$ \\
\hline Sólidos solúveis totais ( $\left.{ }^{\circ} \mathrm{Brix}\right)$ & $54,00 \pm 0,000 \mathrm{c}$ & $62,00 \pm 0,000 \mathrm{~b}$ & $70,00 \pm 0,000 a$ \\
\hline Teor de água (\% b.u.) & $9,85 \pm 0,873 \mathrm{a}$ & $7,71 \mathrm{~b} \pm 0,439 \mathrm{~b}$ & $6,35 \mathrm{c} \pm 0,345 \mathrm{c}$ \\
\hline Sólidos totais (\%) & $90,15 \pm 0,873 \mathrm{~b}$ & $92,04 \pm 0,439 \mathrm{c}$ & $93,65 \pm 0,345 \mathrm{a}$ \\
\hline Acidez total titulável (\% ácido cítrico) & $0,82 \pm 0,009 \mathrm{a}$ & $0,80 \pm 0,000 \mathrm{a}$ & $0,78 \pm 0,000 \mathrm{a}$ \\
\hline Luminosidade $\left(\mathrm{L}^{*}\right)$ & $58,98 \pm 0,06 \mathrm{a}$ & $55,52 \pm 0,06 \mathrm{~b}$ & $51,50 \pm 0,06 \mathrm{c}$ \\
\hline Intensidade de vermelho $\left(+\mathrm{a}^{*}\right)$ & $8,61 \pm 0,01 a$ & $8,55 \pm 0,01 \mathrm{a}$ & $8,52 \pm 0,01 \mathrm{a}$ \\
\hline Intensidade de amarelo (+b*) & $25,86 \pm 0,19 a$ & $24,35 \pm 0,19 b$ & $22,39 \pm 0,19 \mathrm{c}$ \\
\hline Atividade de água $\left(\mathrm{a}_{\mathrm{w}}\right)$ & $0,522 \pm 0,004 \mathrm{a}$ & $0,485 \pm 0,004 \mathrm{~b}$ & $0,470 \pm 0,004 \mathrm{c}$ \\
\hline
\end{tabular}

Obs.: As médias seguidas pela mesma letra nas linhas não diferem estatisticamente de acordo com o teste de Tukey a $5 \%$ de probabilidade

Os valores de $\mathrm{pH}$, sólidos solúveis totais e sólidos totais aumentaram com o aumento da temperatura visto que, ocorreu uma evaporação da água livre e consequentemente uma concentração dos ácidos orgânicos. 0 teor de água e atividade de água diminuíram com o aumento da temperatura. A acidez total titulável durante o processo de secagem diminui em detrimento do aumento do $\mathrm{pH}$. Analisando a cor das fatias de bananas-passa, nota-se que nos parâmetros de luminosidade e intensidade amarelo diminuíram com o aumento da temperatura em torno de 12,68\% e 13,41\%, respectivamente. Essa diminuição foi menor que 15\% comprovando a eficácia do processo de desidratação osmótica nas fatias de bananas-passa quando submetidas a secagem convectiva. Tan et al. (2001) também observaram que pedaços de abacaxi osmodesidratados e secos sofreram menor alteração de cor, do que a fruta sem tratamento, apresentando cor com maior aceitação pelos provadores. Esse fenômeno pode ser explicado pelo açúcar que é impregnado na fruta durante a desidratação osmótica, que cristaliza na superfície da amostra, oferecendo resistência ao escurecimento das mesmas. Já os valores de intensidade de vermelho permaneceram inalterados sem diferenças estatísticas comprovando a manutenção dos pigmentos vermelhos das bananas-passa no processo de secagem.

\subsection{CINÉTICA DE SECAGEM}

A temperatura tem grande influência na cinética de secagem nas fatias de banana passa, porém a secagem a 50,60 e $70{ }^{\circ} \mathrm{C}$ atinge o equilíbrio nos tempos de 2657, 1856 e 1496 minutos, respectivamente, sendo que a $70^{\circ} \mathrm{C}$ o equilíbrio foi alcançado no menor tempo conforme mostra a Figura 1 . De acordo com Formoso et al. (2009) o efeito da temperatura se deve à sua influência sobre o potencial de transferência de água do sólido para o ar de secagem, uma vez que o aquecimento do ar a temperaturas mais elevadas implica na redução de sua umidade relativa, afetando diretamente o potencial de transferência de massa. 0 aumento da temperatura poderá afetar as propriedades físicas da matriz sólida, e facilita a difusão da água. Babalis et al. (2006) trabalharam com secagem de figos nas temperaturas de $55-85^{\circ} \mathrm{C}$ e velocidade do ar de $0,5-$ $3,0 \mathrm{~m} / \mathrm{s}$ e observaram que, aumentando a temperatura de secagem consequentemente ocorreria um aumento na taxa de secagem. Este mesmo efeito foi verificado por Nimmol et al. (2007) quando trabalharam com secagem de fatias de banana em processos combinados de sistema de baixa pressão e radiação infravermelho nas temperaturas de 80 e $90{ }^{\circ} \mathrm{C}$. 
Figura 1 - Curvas de secagem das fatias de banana-passa nas diferentes temperaturas de secagem

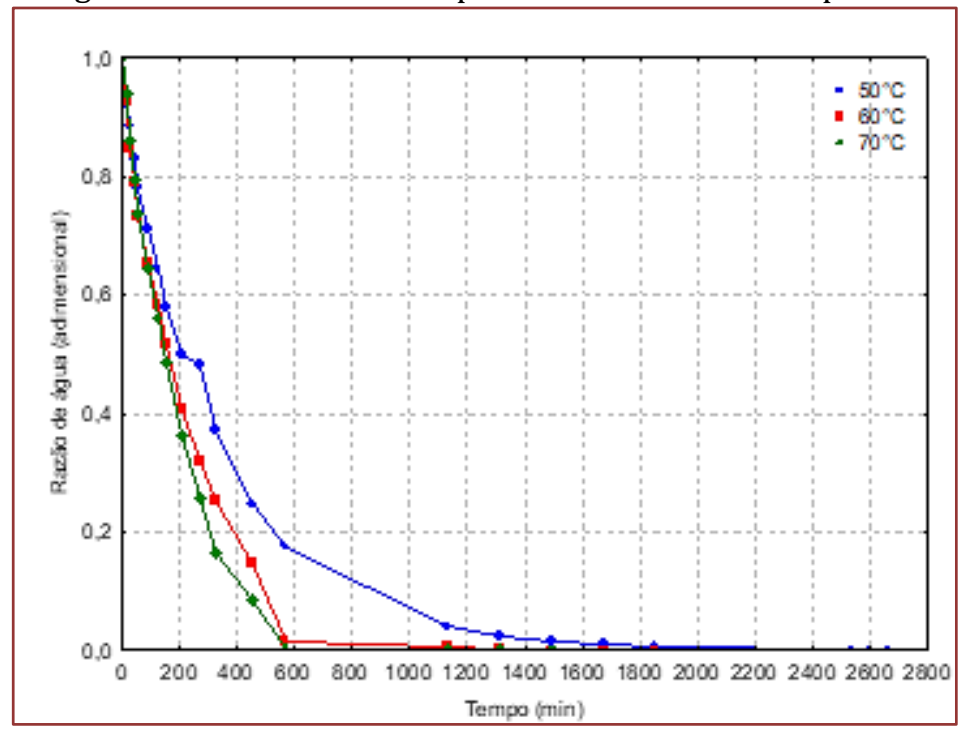

\subsection{ANÁLISE DE ATRIBUTOS SENSORIAIS}

Na Tabela 2 estão apresentadas os resultados dos atributos cor, aparência, odor e sabor de cada amostra de banana-passa tratadas estatisticamente pelo teste de Tukey a $5 \%$ de probabilidade, com uma escala de pontuação de 9 pontos, onde 1 representa a aceitação mínima e 9 a aceitação máxima. As amostras de banana-passa submetidas às temperaturas de 50,60 e $70{ }^{\circ} \mathrm{C}$ para os parâmetros cor, aparência, odor e sabor demonstraram diferenças estatísticas entre si, comprovando que para os provadores a temperatura de secagem influenciou em todos os parâmetros. Resultado similar foi encontrado por Pessoa (2011), quando analisou as amostras de goiaba por processos combinados de desidratação osmótica de secagem convectiva nas temperaturas de $40,50,60$ e $70{ }^{\circ} \mathrm{C}$.

Tabela 2 - Resultados médios dos atributos cor, aparência, odor e sabor da banana-passa submetida a diferentes temperaturas de secagem.

\begin{tabular}{|c|c|c|c|c|}
\multirow{2}{*}{ Banana-passa } & \multicolumn{5}{c|}{ Cor } & \multicolumn{1}{c|}{ Aparência } & \multicolumn{1}{c|}{ Odor } & Sabor \\
\hline $50^{\circ} \mathrm{C}$ & $6,71 \mathrm{c}$ & $6,37 \mathrm{c}$ & $6,55 \mathrm{c}$ & $6,14 \mathrm{c}$ \\
\hline $60^{\circ} \mathrm{C}$ & $7,10 \mathrm{~b}$ & $6,84 \mathrm{~b}$ & $6,75 \mathrm{a}$ & $6,75 \mathrm{a}$ \\
\hline $70^{\circ} \mathrm{C}$ & $7,33 \mathrm{a}$ & $6,96 \mathrm{a}$ & $6,65 \mathrm{~b}$ & $6,49 \mathrm{~b}$ \\
\hline
\end{tabular}

\section{CONCLUSÃO}

As fatias de bananas-passa foram influenciadas pela temperatura durante a secagem. A secagem mais rápida ocorreu na temperatura de $70^{\circ} \mathrm{C}$, devido a maior evaporação da água.

0 processo de secagem convectiva nas temperaturas de 50,60 e $70{ }^{\circ} \mathrm{C}$ alteraram significativamente as características físico-químicas das bananas-passa, permanecendo praticamente constantes a acidez total titulável e a intensidade de vermelho.

As bananas-passa secas a $60^{\circ} \mathrm{C}$ foram as que obtiveram os melhores resultados dos atributos sensoriais.

\section{REFERÊNCIAS}

[1] Alves, F. I. S. (2011). Crescimento vegetativo da bananeira nanica (musa sp) em função do uso de diferentes tipos e dosagens de biofertilizantes. Monografia (Graduação em Licenciatura Plena em Ciências Agrárias). Centro de Humanas e Agrárias, Universidade Estadual da Paraíba, Catolé do Rocha - PB, 32 p.

[2] Babalis, S. J.; Papanicolaou, E.; Kiriakis, N.; Belessiotis, V. G. (2006.) Evaluations of thin-layer drying models for describing drying kinetics of figs (Ficus carica). Journal of Food Engineering, 75(2), 205-214. 
[3] Borges, A. L.; Cordeiro, Z. J. M. (2015). Sistemas de produção de baixo impacto para bananeira. Simpósio Brasileiro $\quad$ Sobre $\quad$ Banicultura. $\quad$ Disponível em http://ainfo.cnptia.embrapa.br/digital/bitstream/item/126851/1/Sistemas-de-producao-de-baixo-impacto.pdf

[4] Brasil. Ministério da Saúde. Agência Nacional de Vigilância Sanitária. (2005). Métodos químicos e físicoquímicos para análises de alimentos. Brasília: Ministério da Saúde, 1017 p.

[5] Formoso, V. C.; Damy, P. C.; Telis, V. R. N. (2009). Secagem por ar quente e degradação de ácido ascórbico em fatias de caqui. In: Congresso de Iniciação Científica, 21., São José do Rio Preto. Anais....São José do Rio Preto: Unesp, CdRom.

[6] Mastrantonio, S. D. S.; Pereira, L. M.; Hubinger, M. D. (2006). Mass transfer and difusion coeficient determination in osmotically dehydrated guavas. In: International Drying Symposium, 15., 2006, Budapest. Anais...Budapest: IDS. Cd-Rom.

[7] Nimmol, C.; Devahastin, S.; Swasdisevi, T.; Soponronnarit, S. (2007) Drying of banana slices using combined low-pressure superheated steam and far infra-red radiation. Journal of Food Engeneering, 81(3), 624-633.

[8] Oliveira, L. F.; Godoy, R. L. O.; Borges, S. V. (2011). Qualidade de jaca (Artocarpus heterophyllus Lam.) desidratada sob diferentes condições de processo. Braz. J. Food Technol., 14(3), 241-248.

[9] Pessoa, T. (2011). Desidratação osmótica seguida de secagem de goiaba para obtenção de passas. Campina Grande, PB: UFPB, 161f. Dissertação (Mestre em Engenharia Agrícola) - Universidade Federal de Campina Grande.

[10] Sena, J. V. C. (2011). Aspectos da produção e mercado da banana no nordeste. Escritório Técnico de Estudos $\begin{array}{llll}\text { Econômicos } & \text { do } & \text { Nordeste-Etene. } & \text { Disponível }\end{array}$ http://edi.bnb.gov.br/content/aplicacao/etene/etene/docs/ire_ano5_n10.pdf

[11] Silva, A. S. (2009). Cinética de secagem em camada fina da banana maçã. Revista de Biologia e Ciências da Terra. 9(2).

[12] Silva, F. A. S. \& Azevedo, C. A. V. de. A New Version of The Assistat-Statistical Assistance Software. In: World Congress On Computers IN Agriculture, 4, Orlando-FL-Usa: Anais... Orlando: American Societyof Agricultural Engineers, 2006. p.393-396.

[13] Sousa Neto, M. A., Maia, G. A., Lima, J. R. (2005). Desidratação osmótica de manga seguida de secagem convencional: avaliação das variáveis de processo. Ciências Agrotécnicas, 29(5), 1021-1028.

[14] Tan, M.; Chua, K. J.; Mujundar, A. S.; Chou, S. K. (2001) Efect of osmotic pre-treatment and infrared radiation on drying rate and color changes during drying of potato and pineapple. Drying Technology, 19(9), 2193-2207. 


\title{
Capítulo 13
}

Presença de resíduos de medicamentos veterinários, contaminantes inorgânicos e dioxina em aves e ovos

\author{
Amanda Teixeira Bittencourt \\ Márcia Keller Alves
}

Resumo: Entende-se por avicultura a criação de aves para produção de alimentos, em especial carne e ovos. Trata-se de uma atividade econômica cada vez mais relevante mundialmente, sendo o Brasil um dos principais exportadores destes produtos. Neste contexto, o controle adequado de resíduos e contaminantes garante um produto de qualidade e seguro ao consumidor final. Objetivo: Verificar a presença de resíduos de medicamentos veterinários, contaminantes inorgânicos e dioxinas em aves e ovos. Método: Foi realizada uma análise documental, na qual foram avaliados os relatórios dos últimos sete anos, resultantes do monitoramento do Plano Nacional de Controle de Resíduos e Contaminantes (PNCRC) em aves e ovos, publicados pelo Ministério da Agricultura, Pecuária e Abastecimento. Os resultados foram apresentados de forma descritiva, de modo que os dados obtidos estão apresentados na forma de tabelas, através de números absolutos (n) e relativos (\%). Resultados: Contaminação por resíduos de medicamentos veterinários foi encontrada em todos os relatórios para aves e a partir de 2014 para ovos. Encontrou-se contaminação de cádmio e arsênio, 50,03 \% (relatório 2010) e 43,98 \% (relatório 2015) acima dos limites máximos permitidos, respectivamente. Encontrou-se ainda, contaminação por dioxina nas aves $(0,54 \%$ do total) e nos ovos (1,40 \%) nos anos 2015 e 2016. Conclusão: Verificou-se presença de resíduos de medicamentos antimicrobianos e dioxinas em aves e ovos e de contaminantes inorgânicos e anticoccidianos em tecidos de aves, demonstrando a necessidade da aplicação contínua do PNCRC, de modo a identificar a contaminação e possibilitar ações preventivas e corretivas na avicultura nacional.

Palavras-chave: Avicultura; Contaminação de alimentos; Resíduos de drogas; Contaminantes químicos em alimentos. 


\section{INTRODUÇÃO}

Há muito tempo a agricultura usa de artifícios durante o processo de produção, aplicando produtos químicos promotores de crescimento, tranquilizantes, entre outros. Estas substâncias podem remanescer no produto na forma original ou ainda, como subprodutos ou metabólitos, representando um potencial risco à saúde do consumidor (PASCHOAL et al, 2008).

o Brasil, como líder na exportação de proteínas de origem animal, tem como desafio a segurança destes alimentos, de modo a garantir a conformidade dos produtos consumidos pelo homem. Com isso, é fundamental a existência de políticas públicas, normas de controle e fiscalização rigorosa aos produtos de origem animal, tal como o monitoramento possibilitado pelos programas setoriais do Plano Nacional de Controle de Resíduos e Contaminantes (PNCRC) (FEDDERN, SCHEUERMANN, 2013).

O PNCRC/Animal tem como objetivo a melhoria da produtividade e da qualidade dos alimentos de origem animal colocados à disposição da população brasileira e proporcionar à nação condições de se adequar do ponto de vista sanitário, às regras do comércio internacional de alimentos, preconizadas pela Organização Mundial do Comércio (OMC) e órgãos auxiliares como a Organização das Nações Unidas para Alimentação e Agricultura (FAO); Organização Mundial da Saúde Animal (OIE); e a Organização Mundial da Saúde (WHO) (BRASIL, 1999).

As ações do PNCRC estão direcionadas para evitar a violação dos níveis de segurança estabelecidos pelo Limite Máximo de Resíduos (LMR), de substâncias autorizadas, bem como a ocorrência de quaisquer níveis de resíduos e compostos químicos de uso proibido no país. Cumprir as metas anuais previstas para o controle de resíduos em produtos de origem animal é devidamente necessário, caso ao contrário, podese implicar em sérios problemas às exportações de produtos cárneos brasileiros para os principais mercados Estados Unidos e União Europeia e também expor o consumidor à nocividade dos resíduos e contaminantes, face a ausência do monitoramento possibilitado pelos programas setoriais do Plano (BRASIL, 1999; FEDDERN, SCHEUERMANN, 2013).

Esta análise documental teve por objetivo verificar, através da análise dos relatórios de 2010 a 2016 do PNCRC, a presença de resíduos e contaminantes em aves e ovos.

\section{MATERIAL E MÉTODOS}

Foi realizada uma análise documental, na qual foram avaliados os resultados do monitoramento do Plano Nacional de Controle de Resíduos e Contaminantes em aves e ovos, publicados pelo Ministério da Agricultura, Pecuária e Abastecimento (MAPA). Foram utilizados os relatórios dos últimos sete anos, relativos aos anos de 2010, 2011, 2012, 2013, 2014, 2015 e 2016, todos disponíveis na página da internet do MAPA.

Os dados analisados foram: substâncias em situação não conforme, número de amostras analisadas, número de não conformidades detectadas, percentual de amostras não conformes e o percentual de amostras conformes. Os resultados foram apresentados de forma descritiva, de modo que os dados obtidos estão apresentados na forma de tabelas, através de números absolutos (n) e relativos (\%).

\section{RESULTADOS E DISCUSSÃO}

0 presente estudo analisou os resultados do monitoramento do PNCRC/Animal. O PNCRC é a ferramenta de gerenciamento de risco adotada pelo MAPA, tendo como principal objetivo promover segurança química dos alimentos de origem animal que são produzidos no Brasil. Os resultados do monitoramento permitem obter dados referentes aos resíduos e contaminantes que podem ser encontrados nas aves e ovos.

A legislação nacional diz que os níveis de contaminantes inorgânicos nos alimentos deverão ser os mais baixos possíveis, devendo prevenir a contaminação do alimento na fonte, aplicar a tecnologia mais apropriada na produção, manipulação, armazenamento e processamento, assim evitando que um alimento contaminado seja comercializado ou consumido (FEDDERN, SCHEUERMANN, 2013). A Tabela 1 mostra que os contaminantes inorgânicos em aves nos anos de 2010 e 2015 encontram-se não conformes em um percentual de $0,20 \%$ e $0,30 \%$, respectivamente. Nos demais anos não foram encontradas inconformidades deste tipo de contaminante. Os ovos não estão incluídos nesta tabela, pois não foi encontrada contaminação com este tipo de contaminante nos mesmos. 
Tabela 1. Resultados da análise de contaminantes inorgânicos em aves nos anos de 2010 a 2016 (PNCRC/Animal/MAPA).

\begin{tabular}{|l|c|c|c|c|c|c|c|}
\hline \multicolumn{1}{c}{ AVES } \\
\multicolumn{1}{c}{ Resultados gerais/ano } & 2010 & 2011 & 2012 & 2013 & 2014 & 2015 & 2016 \\
\hline Número de amostras analisadas (n) & 511 & 532 & 468 & 427 & 365 & 335 & 340 \\
\hline Amostras conformes (\%) & 99,8 & 100 & 100 & 100 & 100 & 99,7 & 100 \\
\hline Número de amostras não conformes (n) & 01 & 0 & 0 & 0 & 0 & 01 & 0 \\
\hline Amostras não conformes (\%) & 0,20 & 0 & 0 & 0 & 0 & 0,30 & 0 \\
\hline
\end{tabular}

O contaminante inorgânico encontrado não conforme no ano de 2010 foi o cádmio, com valor encontrado de $1503 \mu \mathrm{g} / \mathrm{kg}$, e em 2015, encontrou-se arsênio como contaminante inorgânico, com valor de 1439,80 $\mu \mathrm{g} / \mathrm{kg}$. 0 teor máximo do contaminante (TMC) permitido para ambos os contaminantes é de $1000 \mu \mathrm{g} / \mathrm{kg}$, assim, os limites máximos permitidos foram ultrapassados em 50,03 \% e 43,98 \%, respectivamente. No estudo de Filho (2011), foi avaliado 1031 amostras de aves nos anos de 2002 a 2008, para o cádmio foram encontradas amostras contaminadas com níveis abaixo dos limites em 3,8 \% das amostras de fígado. Nos rins, 110 amostras (16,3 \% das testadas) apresentaram resíduos de cádmio sendo que apenas uma ultrapassou os limites da legislação (FILHO, 2011).

O cádmio é um contaminante ambiental extremamente tóxico, classificado em 7ํ lugar no ranque de prioridade da lista de substâncias perigosas da Agência para Substâncias Tóxicas e Registro de Doenças. Este contaminante traz múltiplos problemas à saúde humana, afetando diversos sistemas, como cardiovascular, digestivo, nervoso, renal, reprodutivo e respiratório (ATSDR, 2011; ALEXANDER et al, 2009).

O arsênio, por sua vez, é um metal com uma grande toxicidade, mesmo em baixas concentrações, sendo sua dose letal de $70000 \mu \mathrm{g} / \mathrm{kg}$. Leva a um aumento da permeabilidade capilar, fragmentação da bainha mielínica e infiltração gordurosa no fígado (ANDRADE, ROCHA, 2016). 0 arsênio em condições anaeróbicas origina o arsênio na sua forma inorgânica, podendo se alojar tanto na carne de frango ou ser excretado na cama de frango. Apesar do uso da cama de frango ser proibido, pode-se utilizar na alimentação bovina e na forma de adubos para a agricultura por conter altos níveis de uréia, desta forma, pode contaminar o ambiente e vários produtos consumidos pelos seres humanos (DIONÍSIO et al, 2010).

No que diz respeito à contaminação de antimicrobianos nos relatórios de 2010 a 2016, percebe-se número de amostras não conformes em aves nos anos de 2010, 2011, 2012, 2013, 2014, 2015 e 2016. Os ovos apresentaram amostras não conformes somente nos anos 2014, 2015 e 2016 (Tabela 2).

Tabela 2. Resultados da análise de antimicrobianos em aves e ovos nos anos de 2010 a 2016 (PNCRC/Animal/MAPA).

\begin{tabular}{|c|c|c|c|c|c|c|c|}
\hline \multicolumn{8}{|c|}{ AVES } \\
\hline Resultados gerais/ano & 2010 & 2011 & 2012 & 2013 & 2014 & 2015 & 2016 \\
\hline Número de amostras analisadas (n) & 5315 & 3445 & 2120 & 2073 & 1526 & 2708 & 1981 \\
\hline Amostras conformes (\%) & 99,97 & 99,92 & 99,96 & 99,96 & 99,55 & 99,89 & 99,95 \\
\hline Número de amostras não conformes (n) & 02 & 03 & 01 & 01 & 07 & 03 & 01 \\
\hline Amostras não conformes (\%) & 0,03 & 0,08 & 0,04 & 0,04 & 0,45 & 0,11 & 0,05 \\
\hline \multicolumn{8}{|c|}{ OVOS } \\
\hline Resultados gerais/ano & 2010 & 2011 & 2012 & 2013 & $2014 *$ & 2015 & 2016 \\
\hline Número de amostras analisadas (n) & 237 & 280 & 174 & 117 & 102 & 327 & 337 \\
\hline Amostras conformes $(\%)$ & 100 & 100 & 100 & 100 & 99,02 & 97,25 & 96,74 \\
\hline Número de amostras não conformes (n) & 0 & 0 & 0 & 0 & 1 & 09 & 11 \\
\hline Amostras não conformes (\%) & 0 & 0 & 0 & 0 & 0,98 & 2,75 & 3,26 \\
\hline
\end{tabular}

* Em 2014 a apresentação dos dados no PNCRC, de anticoccidianos e antimicrobianos apresenta-se junto. Porém, a Enrofloxacina que identifica-se uma amostra não conforme é classificada como um antimicrobiano.

Os principais antimicrobianos encontrados nas aves foram sulfaquinoxalina, doxicilina, enrofloxacina, sulfametoxazol, semicarbazida, oxietraciclina e cloranfenicol. Já nos ovos, os antimicrobianos encontrados foram enrofloxacina, nicarbazina, ciprofloxacina, sulfametazina e salinomicina. Os resultados vão de encontro com a literatura, a qual mostra que os antimicrobianos mais observados na avicultura são 
enrofloxacina, oxitetraclina, norfloxacina, doxicilina, sulfaquinoxalina, bacitracina de zinco, amoxicilina, apramicina, ciprofloxacina e a associação de doxiciclina e gentamicina (MACHINSKI et al, 2005).

0 uso de medicamentos veterinários na avicultura de postura no Brasil para prevenção ou tratamento de patologias pode ocasionar a presença de resíduos nos alimentos, o que gera preocupação dos órgãos de saúde, pela possibilidade de que o uso de antimicrobianos em animais venha a aumentar a incidência/prevalência de bactérias resistentes a estes medicamentos (BORSOI, NETO, 2015).

No que se refere aos anticoccidianos, foram localizadas não conformidades nas amostras de aves em seis dos sete relatórios analisados. Os ovos não estão incluídos nesta tabela, pois não foi encontrada contaminação com este tipo de medicamento nos mesmos (Tabela 3).

Tabela 3. Resultados da análise de anticoccidianos em aves nos anos de 2010 a 2016 (PNCRC/Animal/MAPA).

\begin{tabular}{|c|c|c|c|c|c|c|c|}
\hline \multicolumn{8}{|c|}{ AVES } \\
\hline Resultados gerais/ano & 2010 & 2011 & 2012 & 2013 & 2014 & 2015 & 2016 \\
\hline Número de amostras analisadas (n) & 663 & 615 & 588 & 590 & 478 & 447 & 603 \\
\hline Amostras conformes (\%) & 99,85 & 99,68 & 100 & 99,67 & 98,54 & 99,33 & 99,17 \\
\hline Número de amostras não conformes (n) & 01 & 02 & 0 & 02 & 07 & 03 & 05 \\
\hline Amostras não conformes (\%) & 0,15 & 0,32 & 0 & 0,33 & 1,46 & 0,67 & 0,83 \\
\hline
\end{tabular}

A nicabarzina foi o anticoccidiano analisado com maior número de amostras não conformes, em que 17 amostras excederam os limites de tolerância $(200 \mu \mathrm{g} / \mathrm{kg})$. Em 2016, a lasolacida teve seu limite de tolerância ultrapassado $(20 \mu \mathrm{g} / \mathrm{kg})$ em três das amostras analisadas. A utilização de anticoccidianos como medida preventiva a coccidiose na produção de animais é indispensável, de tal modo, que contribui significativamente para a sanidade e bem-estar dos animais, prevenindo esta doença que está presente em quase todas as explorações zootecnias (SOAVE, 2011).

0 controle da coccidiose em frangos de corte é feito através da administração preventiva de drogas anticoccidianas na ração ou através de vacinas. Porém, o estudo de Meireles (2003) relata alguns surtos devido a ocorrência de falhas na profilaxia da coccidiose, entre elas a resistência do parasito às drogas utilizadas. A coccidiose em galinhas é causada por protozoários do gênero Eimeria, se estabelecendo mesmo após os constantes avanços referentes à sua profilaxia (MEIRELES et al, 2003).

Na tentativa de minimizar os prejuízos causados pela coccidiose, tais como depressão de desempenho e consequentemente aumento do custo de produção, vários fármacos são lançados no mercado mundial com vista ao combate da coccidiose, podendo ser administrados isoladamente ou combinados nas rações e nas diferentes fases de vida das aves (DONZELE et al, 2001).

Um estudo avaliou a determinação de resistência a drogas anticoccidianas de isolados de Eimeria de frangos de corte. Foi analisada resistência contra nicabarzina, robenidina, monensina, narasina, salinomicina, maduramicina, diclazuril, semduramicina e lasalocida, através da análise do ganho de peso e escore de lesões por meio de aves infectadas, comparados aos de aves não infectadas. Os resultados observados no estudo indicaram resistência de Eimeria tenella e Eimeria acervulina a todas drogas utilizadas, com exceção do diclazuril (MEIRELES et al, 2003).

O emprego de Boas Práticas de Medicação diminui significativamente os riscos à saúde humana. Tratando os animais de forma correta, evita-se a presença de resíduos em carne e ovos, assim como o desenvolvimento de formas resistentes de microrganismos. Deste modo, o uso prudente dos medicamentos veterinários torna-se imprescindível por parte das indústrias (BORSOI, NETO, 2015).

As dioxinas, cujos resultados da análise se apresentam na Tabela 4, são compostos orgânicos policlorados, os quais são conhecidos pelos efeitos adversos para a saúde humana e animal, trazendo problemas de desenvolvimento embrionário e físico, carcinogênicos e reprodutivos. Como mostra a tabela, foi encontrada dioxina nas amostras de aves nos anos de 2015 e 2016. Nos ovos, foi encontrada uma amostra não conforme no ano de 2016. 
Tabela 4. Resultados da análise de dioxinas em aves e ovos nos anos de 2010 a 2016 (PNCRC/Animal/MAPA).

\begin{tabular}{|c|c|c|c|c|c|c|c|}
\hline \multicolumn{8}{|c|}{ AVES } \\
\hline Resultados gerais/ano & 2010 & 2011 & 2012 & 2013 & 2014 & 2015 & 2016 \\
\hline Número de amostras analisadas (n) & NA & NA & 60 & 64 & 14 & 291 & 305 \\
\hline Amostras conformes $(\%)$ & - & - & 100 & 100 & 100 & 98,97 & 99,68 \\
\hline Número de amostras não conformes (n) & - & - & 0 & 0 & 0 & 3 & 1 \\
\hline Amostras não conformes (\%) & - & - & 0 & 0 & 0 & 1,03 & 0,32 \\
\hline \multicolumn{8}{|l|}{ 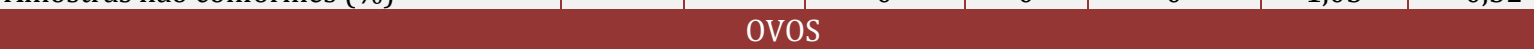 } \\
\hline Resultados gerais/ano & 2010 & 2011 & 2012 & 2013 & 2014 & 2015 & 2016 \\
\hline Número de amostras analisadas (n) & NA & NA & NA & NA & NA & 18 & 53 \\
\hline Amostras conformes $(\%)$ & - & - & - & - & - & 100 & 98,11 \\
\hline Número de amostras não conformes (n) & - & - & - & - & - & 0 & 1 \\
\hline Amostras não conformes (\%) & - & - & - & - & - & 0 & 1,89 \\
\hline
\end{tabular}

NA - Não avaliado

A dioxina PCDD/PCDF-TEQ-OMS se apresenta não conforme nas aves e ovos e tem como limite de referência 1,75 pg/g e 2,50 pg/g, respectivamente, o qual foi ultrapassado nos anos de 2015 e 2016. Nos tecidos das aves, no ano de 2015, três amostras ficaram acima do limite de referência, com percentuais que variaram entre $101,71 \%, 64,57 \%$ e $61,14 \%$. No ano de 2016 , ocorreu uma amostra não conforme com percentual de $22,28 \%$. Para os ovos, encontra-se uma amostra não conforme no ano de 2016 com valor de 4,49 pg/g, ultrapassando o limite de referência em 79,6 \%.

As dibenzo-p-dioxinas policloradas (PCDD, polychlorinated-p-dibenzodioxins) e os dibenzo furanos policlorados (PCDF, polychlorinated-p-dibenzofurans), comumente chamadas de dioxinas e furanos, são duas classes de compostos aromáticos tricíclicos, de função éter, com estrutura quase planar e que possuem propriedades físicas e químicas semelhantes (ASSUNÇÃO, PESQUERO, 1999).

Em 2005, o PNCRC encontrou presença de dioxinas em carne de frango, em quantidade superior à estabelecida pelo Regulamento Comunitário para aquele contaminante. Assim, a Autoridade para a Segurança Alimentar e Econômica (ASAE) realizou a avaliação dos efeitos para a saúde humana do consumo de frango contaminado com níveis de dioxinas os quais consistem em alterações no sistema imunológico, reprodutor e hormonal e são considerados cancerígenos pela Organização Mundial da Saúde (ANESA, 2006).

Trata-se de compostos altamente tóxicos muito persistentes, detectados em todas as matrizes ambientais, tais como solo, sedimentos, ar, água, animais e vegetais; emissões destes compostos para a atmosfera ocorrem principalmente nos processos de combustão. As dioxinas apresentam-se em maior concentração em alimentos de origem animal tais como carne, leite, ovos, peixe e seus derivados (ASSUNÇÃO, PESQUERO, 1999).

Torna-se evidente que a efetividade de ações só será alcançada mediante entrosamento e ação conjunta de todas as organizações e segmentos sociais envolvidos na cadeia produtiva de alimentos, com compartilhamento das responsabilidades das autoridades federais, estaduais e municipais e coordenação entre estruturas de registro, fiscalização e avaliação laboratorial. Assim, pode-se criar uma estrutura eficaz para identificar, prevenir e eliminar os riscos à saúde humana, devido ao uso de resíduos e contaminantes em animais de produção (SPISSO et al, 2009).

As amostras que são utilizadas pelo MAPA são coletadas pelo Serviço de Inspeção Federal (SIF) de lotes de animais e produtos de uma única origem, o que permite a rastreabilidade da propriedade rural de origem do produto. Se acontecer alguma infração, são propostos subprogramas para investigação, os quais incluem a fiscalização da propriedade rural responsável pelo lote amostrado para identificação das causas da violação, e para evitar que possa ocorrer novas violações. As propriedades rurais violadoras têm seus próximos lotes e produtos submetidos a teste feito pelo serviço oficial até que o resultado indique sua conformidade, isto se mantém até que cinco lotes consecutivos resultem em produtos conformes (BRASIL, 2017).

O PNCRC desenvolve as suas atividades visando conhecer o potencial de exposição da população aos resíduos nocivos à saúde do consumidor, orientar para a adoção de políticas nacionais de saúde animal e fiscalização sanitária, e principalmente o uso de drogas veterinárias proibidas no território nacional. Deve-se ressaltar que nem todas as drogas ou compostos químicos que os animas são expostos possuem resíduos que sejam perigosos a saúde humana e animal. Mesmo os compostos químicos que são 
considerados nocivos, serão prejudiciais somente se ultrapassarem o valor estabelecido pelo limite de tolerância, limite de segurança ou LMR (BRASIL, 1999).

\section{CONCLUSÃO}

As aves tiveram amostras não conformes, as quais excederam o limite máximo de tolerância para contaminantes inorgânicos, antimicrobianos, anticoccidianos e dioxinas nos anos de 2010 a 2016. Já os ovos, apresentaram percentual de amostras não conformes de antimicrobianos e dioxinas nos relatórios analisados. É necessária a aplicação contínua do PNCRC para obtenção dos dados e utilizá-los como forma de controle, identificando a contaminação e trabalhando de forma preventiva.

\section{REFERÊNCIAS}

[1] Alexander, J. et al. Cadmium in food. Scientific Opinion of the Panel on Contaminants in the Food Chain. The EFSA Journal (2009) 980, 1-139.

[2] Andrade, D.F.; Rocha, M.S. A toxicidade do arsênio e sua natureza. Centro de Pós-Graduação Oswaldo Cruz. no 3, n.10 abril-junho 2016 ISSN 2357-81873.

[3] Assunção, J.V; Pesquero, C. R. Dioxinas e furanos: Origens e riscos. Rev. Saúde Pública, 33 (5): 523- 30, 1999. www.fsp.usp.br/rsp.

[4] ATSDR. Cadmium. Agency for Toxic Substances e Disease Registry (http://www.atsdr.cdc.gov), 2011.

[5] Borsoi, A.; Neto, J.P. Uso de antimicrobianos na postura comercial. Problema de saúde aviária ou de saúde pública? Departamento de Patologia, Faculdade de Medicina Veterinária e Zootecnia da Universidade de São Paulo, SP, Brasil, 2015.

[6] Brasil. Ministério da Agricultura, Pecuária e Abastecimento. Instrução Normativa № 42, 1999.

[7] Brasil. Ministério da Agricultura, Pecuária e Abastecimento. Plano Nacional de Controle de Resíduos e Contaminantes. Publicado em 24/03/2017, última modificação 28/08/2017. Acesso em: http://www.agricultura.gov.br/assuntos/inspecao/produtos-animal/plano-de-nacional-de-controle-de-residuos-econtaminantes.

[8] Dionísio, A.G.G.; Gonzalez, M.H.; Joaquim, A.N. Determinação de arsênio em amostras da cadeia produtiva de frangos de corte por espectrometria de absorção atômica com forno de grafite. Quim. Nova, Vol. 34, No. 1, 49-52, 2011.

[9] Donzele, J.L. et al. Efeito da Nicarbazina sobre o Desempenho de Frangos de Corte Recebendo Diferentes Níveis de Lisina Submetidos a Estresse por Calor. Rev. bras. zootec., 30(3):1052-1057, 2001.

[10] Feddern, V.; Scheuermann, G.N. Atualidade sobre análise de resíduos químicos em aves. Avicultura industrial, no 04, 2013.

[11] Filho, J.F.A. Ocorrência de arsênio, cádmio e chumbo em tecidos de aves, suínos, bovinos de corte e equinos no Brasil. Escola de veterinária da Ufmg. Belo Horizonte, 2011.

[12] Machinski J.M. et al. Medicamentos veterinários utilizados na avicultura de postura no estado do Paraná. PAMvet/ PR, 2005.

[13] Meireles, M.V. et al. Avaliação da resistência de isolados de campo de Eimeriade frangos de corte a drogas anticoccidianas. Revista Brasileira de Ciência Veterinária - RBCV. volume 10, no 02, p 72-77, maio/agosto, 2003.

[14] Paschoal, J.A.R. et al. Validação de métodos cromatográficos para a determinação de resíduos de medicamentos veterinários em alimentos. Quím. Nova [online]. 2008, vol.31, n.5, pp.1190-1198. ISSN 01004042. http://dx.doi.org/10.1590/S0100-40422008000500048.

[15] Soave, G. L. Anticoccidianos em rações. Revista eletrônica: www.nutritime.com.br. Artigo 128, volume 08, no 01. p 1401- 1417, janeiro/ fevereiro, 2011.

[16] Spisso, B.F.; Nóbrega, A.W.; Marques, M.A.S. Resíduos e contaminantes químicos em alimentos de origem animal no Brasil: histórico, legislação e atuação da vigilância sanitária e demais sistemas regulatórios. Ciência \& Saúde Coletiva, vol. 14, núm. 6, diciembre, 2009, pp. 2091-2106. Associação Brasileira de Pós-Graduação em Saúde Coletiva Rio de Janeiro, Brasil. 


\section{Capítulo 14}

\section{Aceitação e avaliação sensorial de queijos caprinos pelo método CATA (Check-All-That-Apply)}

\section{Selene Daiha Benevides}

Deborah dos Santos Garruti

Idila Maria da Silva Araújo

Carlos Ruan Vieira de Sousa

Luis Eduardo Laguna

Antônio Silvio do Egito

Resumo: Os produtores de queijos caprinos têm demandado por novas tecnologias visando a diversificação e maior oferta de novos produtos, agregando valor à cadeia produtiva. Este estudo teve por objetivo avaliar, no Estado do Ceará, a aceitação e as características sensoriais de três tipos de queijos caprinos desenvolvidas pela Embrapa: cremoso probiótico, Coalho defumado e maturado, e Coalho adicionado de óleo de pequi (Caryocar coriaceum Wittm). Os produtos apresentaram boa aceitação por parte dos clientes regulares de um supermercado local (Fortaleza), afirmando estarem abertos a inseri-los na dieta. Os queijos foram considerados com boa aparência e sabor, idealmente salgado e não amargo. 0 queijo defumado foi o único que não apresentou aroma e sabor de leite caprino, o probiótico foi considerado ligeiramente ácido e o Coalho com pequi apresentou aroma e sabor frutados. Os resultados sugerem que as características sensoriais percebidas pelos consumidores podem dar suporte a finalização das respectivas tecnologias.

Palavras-chave: inovação, leite, lácteos de cabra; hedônica, caracterização sensorial.

*A Empresa Brasileira de Pesquisa Agropecuária - Embrapa é detentora dos direitos patrimoniais da obra. 


\section{INTRODUÇÃO}

O setor da caprinocultura leiteira no Brasil vem se destacando no país, com a produção de 150.000 toneladas de leite de cabra no ano de 2012 (FAO, 2016). Parte desse leite é pasteurizada visando atender aos programas sociais do governo e parte é utilizada na elaboração de derivados lácteos, principalmente queijos. Devido ao estímulo do governo para aumento da produção de leite, vem aumentando o volume de excedente. Por esse motivo, os produtores têm demandado por novas tecnologias de aproveitamento que visam diversificar os derivados lácteos caprinos, possibilitando maior oferta de novos produtos e agregação de valor à cadeia produtiva.

Durante o desenvolvimento e melhoria de produtos alimentares, as empresas devem se esforçar para conhecer os desejos e necessidades dos consumidores, bem como entender como os consumidores percebem os seus produtos (VARELA e ARES, 2012). Os testes sensoriais afetivos envolvem diversos métodos, entre eles, o teste de aceitação (escala hedônica) e o método descritivo rápido Check-all-thatapply - CATA. No teste hedônico, o provador expressa o grau de gosto ou desgosto em relação ao produto avaliado, usando uma escala previamente estabelecida, geralmente com nove categorias. 0 método CATA possui um questionário constituído por questões de resposta múltipla, consistindo numa lista de descritores (palavras ou frases), em que os provadores escolhem aqueles que melhor caracterizam cada produto. É comum o uso desse método simultaneamente com a escala hedônica para, por meio de uma caracterização dos produtos realizada pelos próprios consumidores, entender os atributos sensoriais que determinam a preferência, incluindo padrões de segmentação (NG et al., 2013; PLAEHN, 2012).

A Embrapa vem desenvolvendo tecnologias de queijos de leite de cabra, ora desenvolvendo tipos de queijo tradicionais e utilizando materiais disponíveis na biodiversidade brasileira, ora procurando adaptálos aos tipos de queijos internacionais, de forma a diversificar os produtos caprinos e estimular o consumo, com consequente melhoria de renda dos produtores.

Há, na literatura, relatos a respeito de avaliação sensorial de produtos lácteos (ANTUNES et al., 2009; CASTRO et al., 2013), mas poucos com queijos caprinos. Portanto, o objetivo deste trabalho foi avaliar, no Estado do Ceará, onde a população está familiarizada com o leite de cabra, a aceitação e as características sensoriais de três tipos de queijo de leite de cabra desenvolvidos pela Embrapa: queijo Coalho adicionado de óleo de pequi (Caryocar coriaceum Wittm), queijo Coalho maturado defumado e queijo cremoso probiótico visando o repasse das tecnologias aos produtores de outras regiões do país.

\section{MATERIAL E MÉTODOS}

\subsection{QUEIJOS CAPRINOS}

Os queijos caprinos cremoso probiótico, Coalho maturado e defumado e Coalho adicionado de óleo de pequi (C. coriaceum Wittm) foram produzidos na Embrapa Caprinos e Ovinos, em Sobral, no Ceará, com leite oriundo de rebanho caprino próprio, seguindo as metodologias descritas por Santos et al. (2010), Laguna e Egito (2008) e Benevides et al. (2010), respectivamente. Em seguida, foram embalados a vácuo e armazenados em câmara refrigerada a $8^{\circ} \pm 2{ }^{\circ} \mathrm{C}$, até a realização dos testes sensoriais.

\subsection{TESTES SENSORIAIS}

A análise sensorial dos três tipos de queijos foi desenvolvida em um supermercado de classe média a alta, em Fortaleza, CE, com 102 consumidores não treinados, recrutados dentre frequentadores desse estabelecimento comercial, conforme especificado por Meilgaard et al. (2006) e Stone e Sidel (1993). Os provadores foram caracterizados quanto a gênero, idade, escolaridade, profissão, renda familiar, hábito e frequência do consumo de queijos de um modo geral, hábito do consumo de queijos caprinos, o quanto gosta e desgosta de queijos caprinos, se gosta de experimentar novos alimentos e se estaria disposto a experimentar novos alimentos. Antes da execução dos testes sensoriais foi solicitado aos provadores que assinassem um Termo de Consentimento Livre e Esclarecido (TCLE). Os protocolos dos testes sensoriais foram previamente aprovados pelo Comitê de Ética em Pesquisa com Seres Humanos (COEP) da Universidade Estadual Vale do Acaraú (UVA), sob o protocolo CAAE 02519212.5.0000.5053, conforme a resolução número 196/96 do Conselho Nacional de Saúde (BRASIL, 1996).

Os queijos Coalho (ambos com 30 dias de maturação) foram apresentados em cubos medindo 1,5 cm de aresta e o queijo cremoso probiótico, uma porção de $20 \mathrm{~g}$ servida com torrada. As amostras foram dispostas em copinhos descartáveis codificados com números aleatórios de três dígitos (WALKELING e 
MACFIE, 1995) e apresentados de forma monádica e balanceada (MACFIE et al., 1989) para minimizar os efeitos de posição das amostras. Um copo de água mineral foi oferecido entre as amostras, para eliminar o sabor residual na boca.

Foram aplicados testes afetivos de aceitação global fazendo-se o uso da escala hedônica de 9 pontos, variando de "desgostei muitíssimo" (nota 1) a "gostei muitíssimo" (nota 9) (PERYAM e PILGRIM, 1957) e o teste CATA (check-all-that-apply) (MEYNERS e CASTURA, 2014), em que os consumidores marcaram os termos descritores que identificavam estar relacionados aos atributos de cor, aparência, aroma, sabor e textura de cada amostra.

\subsection{ANÁLISES ESTATÍSTICAS}

Para efeito de análise estatística, as categorias da escala hedônica foram associadas a valores numéricos, sendo 9 (gostei muitíssimo), 8 (gostei muito), 7 (gostei), 6 (gostei pouco), 5 ("nem gostei/nem desgostei), 4 (desgostei pouco), 3 (desgostei), 2 (desgostei muito) e 1 (desgostei muitíssimo). Os dados dos testes de aceitação foram submetidos à Análise de Variância (ANOVA) e teste de Tukey $(\mathrm{p}<0,05)$ para determinar diferença entre as médias, utilizando o programa estatístico Statistical Analytical Systems (SAS) Versão 6.11 (SAS, 1996). Também foi calculado um índice de aceitação pelo somatório das frequências acumuladas na região de aceitação da escala hedônica (valores de 6 a 9) para cada amostra. A Análise de Correspondência foi aplicada na tabela de frequências contendo as amostras nas linhas e os descritores sensoriais nas colunas, utilizando o programa XLSTAT®, versão 6.11.

\section{RESULTADOS E DISCUSSÃO}

0 público participante dos testes sensoriais foi formado predominantemente por pessoas do sexo feminino (63\%), com faixa etária de 18 a 66 anos que possuía, em sua maioria (43\%), renda familiar entre 1 e 5 salários mínimos. Quanto ao hábito de consumir queijos, 56\% consomem diariamente e 31\% somente duas vezes por semana. Do total de consumidores, somente $41 \%$ havia experimentado queijo de cabra, e destes, $22 \%$ afirmaram não gostar/nem desgostar e apenas $4 \%$ afirmaram gostar extremamente. Cerca de $40 \%$ acharam que os preços dos queijos caprinos são caros ou muito caros, $85 \%$ afirmaram gostar moderamente ou extremamente de experimentar novos alimentos e 30\% afirmaram estar dispostos a inserir o queijo de cabra em suas dietas.

Os queijos caprinos desenvolvidos apresentaram boa aceitabilidade em Fortaleza, com médias hedônicas acima de 6,5. 0 queijo cremoso probiótico foi o mais aceito com média 7,4, entre "gostei" e "gostei muito" na escala hedônica, diferindo significativamente $(\mathrm{p}<0,05)$ dos queijos Coalho maturado defumado e Coalho com óleo de pequi, ambos com média 6,7, entre "gostei pouco" e "gostei". De um modo geral, os queijos analisados apresentaram índices de aceitabilidade variando de 80 a $90 \%$, bem superiores ao valor mínimo (70\%) necessário para que o produto seja considerado aceito (TEIXEIRA et al., 1987) conforme mostra a Figura 1.

Figura 1 - Índice de aceitabilidade sensorial de queijos de leite de cabra

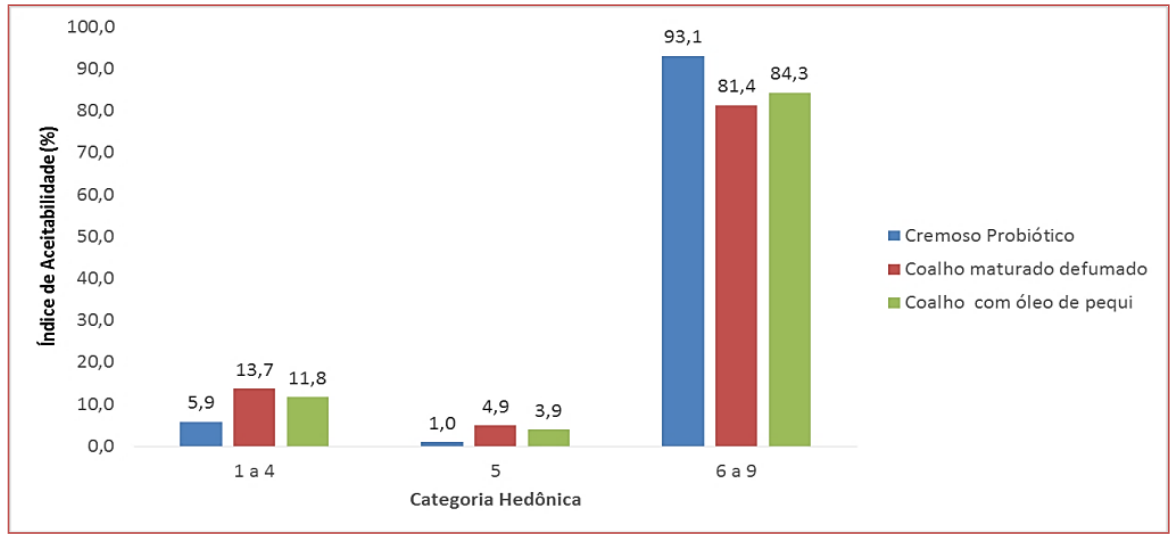


A representação dos dados obtidos com o método CATA indicou que alguns termos foram igualmente percebidos para os três queijos, conforme mostra a Figura 2. Apesar do fato da frequência dos termos citados estarem estreitamente relacionados à intensidade, esse teste não fornece informação quantitativa, uma vez que os consumidores só avaliam se um termo é apropriado ou não para descrever o produto, e não registram a intensidade percebida (VARELA e ARES, 2012).

Figura 2 - Descritores das características sensoriais de queijos de leite de cabra determinados pelo método CATA.

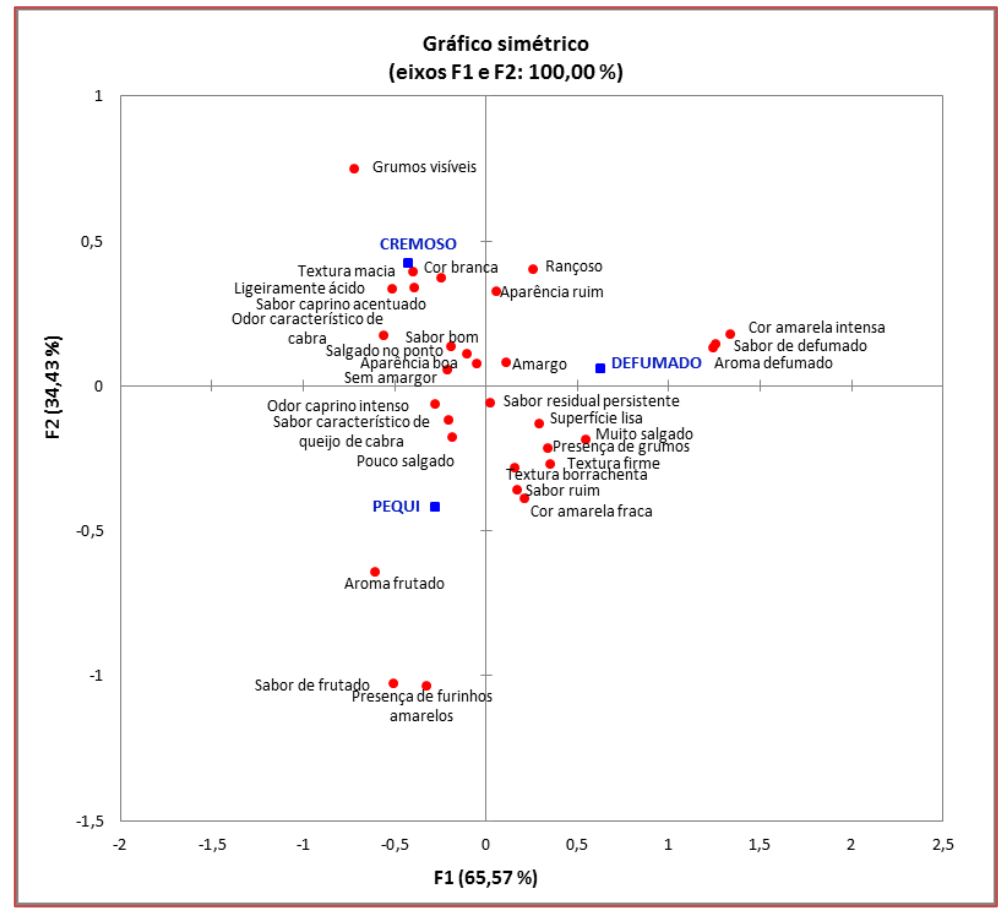

Quanto às características sensoriais, em geral, os queijos foram considerados com aparência boa, gosto salgado no ponto e sem amargor, sabor bom e persistente. 0 queijo cremoso probiótico apresentou coloração branca e grumos visíveis, contudo associados à aparência boa, odor característico de cabra, sabor caprino acentuado com ligeira acidez e textura macia. 0 queijo Coalho maturado defumado foi caracterizado como de cor amarela mais intensa, superfície lisa, sabor e aroma de defumado. 0 queijo Coalho com óleo de pequi apresentou odor caprino mais intenso e sabor característico de queijo de cabra, porém não associado a sabor ruim. A presença de furinhos amarelos que confere a ele cor amarela fraca, além do sabor e aroma frutado é o que mais o diferencia dos demais queijos avaliados. Foi observada frequências muito baixas dos termos aparência ruim, sabor ruim, rançoso, borrachento, textura grumosa e amargo para caracterizar as amostras de queijo.

\section{CONCLUSÕES}

Os queijos de leite de cabra cremoso probiótico, Coalho maturado defumado e Coalho com óleo de pequi apresentam boa aceitação junto a consumidores frequentadores de um supermercado na cidade de Fortaleza, CE, os quais estão dispostos a inserí-los na dieta. Todos os queijos foram considerados com boa aparência e sabor, salgado no ponto e sem gosto amargo. 0 queijo Coalho maturado defumado destaca-se por não apresentar aroma e sabor de leite de cabra, enquanto o queijo Coalho com óleo de pequi apresenta ainda sabor e aroma frutado. Os resultados sugerem que dados das características sensoriais coletados diretamente da percepção dos consumidores podem servir como subsídios para o desenvolvimento e finalização das novas tecnologias de queijo de leite de cabra. 


\section{REFERÊNCIAS}

[1] ANTUNES, A. E. C., SILVA, E. R. A., VAN DENDER, A. G. F., MARASCA, E. T. G., MORENO, I., FARIA, E.V., et al. (2009). Probiotic buttermilk-like fermented milk product development in a semi-industrial scale: Physicochemical, microbiological and sensory acceptability. International Journal of Dairy Technology, 62,556-563.

[2] BENEVIDES, S. D.; SANTOS, K. M. O. dos; EGITO, A. S. do; VIEIRA, A. D. S.; LAGUNA, L. E.; BURITI, A. C. A. Processamento de queijo de coalho de leite de cabra adicionado de óleo de pequi. Sobral: Embrapa Caprinos e Ovinos, 2009. 6 p. (Embrapa Caprinos e Ovinos. Comunicado Técnico, 103). 2009.

[3] BRASIL. Ministério da Saúde. Resolução nº 196 de 10 de outubro de 1996. Aprova as diretrizes e normas regulamentadoras de pesquisas envolvendo seres humanos. Diário Oficial [da] República Federativa do Brasil, Brasília, 1996.

[4] CASTRO, W. F.; CRUZ, A. G.; BISINOTTO, M. S.; GUERREIRO, L. M. R.; FARIA, J. A. F.; BOLINI, H. M. A., et al. Development of probiotic dairy beverages: Rheological properties and application of mathematical models in sensory evaluation. Journal of Dairy Science, 96, 16-25, 2013.

[5] FAO. FOOD AND AGRICULTURE ORGANIZATION OF THE UNITED NATIONS. FAOSTAT. Disponível em: http://faostat.fao.org. Acesso em: 26 agosto 2016.

[6] LAGUNA, L. E.; EGITO, A. S. Processamento do queijo de coalho fabricado com leite de cabra maturado e defumado. Sobral: Embrapa Caprinos e Ovinos, 2008. 5 p. il. (Embrapa Caprinos e Ovinos. Comunicado Técnico, 90). Prática e Processo Agropecuário. 2008.

[7] MACFIE, H. J; BRATCHELL, N.; GREENHOFF, K.; VALLIS, L. Designs to balance the effect of order of presentation and first-ordr-carry-over effects in hall tests. Journal of Sensory Studies, n. 4, p. 129-148, 1989.

[8] MEILGAARD, M.; CIVILLE, G. V.; CARR, B. T. Sensory evaluation techniques, 4. ed. Boca Raton: CRC Press, 2006, 464 p.

[9] MEYNERS, M.; CASTURA, J. C. Check-All-That- Apply Questions. In; P. Varela \& G. Ares (Eds.). Novel Techniques in Sensory Characterization and Consumer Profiling. Boca Raton: CRC Press, Taylor \& Francis Group, p. 272-305, 2014.

[10] NG, M.; CHAYA, C.; HORT, J. The influence of sensory and packaging cues on both liking and emotional, abstract and functional conceptualisations. Food Quality and Preference, 29, 146-56, 2013.

[11] PERYAM, D. R.; PILGRIM, F. J. Hedonic scale method of measuring food preferences. Food Technology, v. 11, n. 9, p. 9-14, 1957.

[12] PLAEHN, D. CATA penalty/reward. Food Quality and Preference, 24, 141-152, 2012.

[13] SANTOS, K. M. O.; VIEIRA, A. D. S.; BENEVIDES, S. D.; BURITI, F. C. A.; EGITO, A. S. do; LAGUNA, L. E. Processamento de queijo caprino probiótico tipo coalho adicionado de Lactobacillus acidophilus. Sobral: Embrapa Caprinos e Ovinos, 2010. 8 p. (Embrapa Caprinos e Ovinos. Comunicado Técnico, 119). Prática /Processo agroindustrial. 2010.

[14] STATYSTICAL ANALISYS SISTEM. SAS/STAT. User's guide. 11. ed. Cary, 1996.

[15] STONE, H. S.; SIDEL, J. L. Sensory evaluation practices. San Diego: Academic Press, 1993. 308 p. Version 6.

[16] TEIXEIRA, E.; MEINERT, E. M.; BARBETTA, P. A. Métodos sensoriais. In: Análise sensorial de alimentos. Florianópolis, Editora da UFSC, 1987, p. 66-119.

[17] VARELA, P; ARES, A. Sensory profiling, the blurred line between sensory and consumer science. A review of novel methods for product characterization. Food Research International, 48 (2012) 893-908.

[18] WALKELING, I. N.; MACFIE, J. H. Designing consumer trials balanced for first and higher orders of carry-over effect when only a subset of k samples from t may be tested. Food Quality and Preference, Oxford, v. 6, n. 4, p. 299-308, 1995. 


\section{Capítulo 15}

\section{Fabricação de queijo minas frescal zero lactose}

\section{Livia Borges de Sousa}

Karla Vitória Alves Sampaio

Milena Silva Correia

Renata Cunha dos Reis

Ulisses Rodrigues de Alencar

Diva Mendonça Garcia

Resumo: Com objetivo de avaliar os efeitos da adição da enzima lactase no leite integral para produção de queijos com reduzido teor de lactose, foi elaborado o queijo controle com lactose (LL) e os adicionados de enzima antes (LEAN) e depois (LEAP) da coagulação, com utilização de leite pasteurizado. Para a produção do queijo elaborado com leite sem lactose (LSL), o leite utilizado foi do tipo UHT, semi-desnatado e zero lactose. Foram feitas análises de $\mathrm{pH}$ e acidez, para avaliar a vida útil dos queijos. Determinou-se também, os teores de umidade, cinzas, gordura, lactose, parâmetros de cor e aceitação sensorial dos queijos elaborados. A quantidade de cloreto de cálcio adicionada pode ter definido o teor de umidade e rendimento nos queijos que utilizaram leites pasteurizados, visto que, o queijo de maior rendimento e de umidade intermediária foi o que obteve maior teor de cinzas e o queijo com menor teor de umidade e com segundo maior teor de cinzas, obteve também o segundo maior rendimento. A recuperação do teor de gordura no queijo pode ter como interferente a manipulação mecânica durante o processo e a rapidez do corte, juntamente com a intensidade da agitação e o tamanho final dos grãos. A aceitação sensorial do queijo LEAN foi a mesma do queijo LL. Conclui-se que a adição da enzima lactase comercializada em farmácias é eficaz na redução do teor de lactose em queijo minas frescal e que os queijos elaborados com enzima lactase e com leite sem lactose comercial possuem maior vida útil em relação ao queijo fabricado com leite com lactose, porém os queijos com reduzido teor de lactose apresentaram custo elevado em relação ao queijo com lactose. É possível fabricar queijo minas frescal com baixo teor de lactose com as mesmas características sensoriais de queijo com lactose.

Palavras-chave: enzima, lactase, intolerância, coagulação. 


\section{INTRODUÇÃO}

0 queijo minas frescal é obtido da coagulação enzimática do leite, seguida ou não, da adição de cultura láctea para a coagulação ácida, cujos ingredientes obrigatórios são o leite e o coagulante, responsáveis pela formação da consistência macia, sabor suave e cor esbranquiçada, características de um produto fresco (BRASIL, 1997). 0 queijo caracteriza-se por ser bastante consumido no Brasil, sendo vendido na forma cilíndrica, possuindo um alto teor de umidade (55\% a 58\%) e sua textura específica fechada a semiaberta (SILVA, 2005), podendo ser consumido em até 10 dias depois da fabricação (FRADE, 2011). Por conta disso, são realizadas análises de $\mathrm{pH}$ e acidez que avaliam a vida útil do queijo, uma vez que existe uma relação entre o aumento de microrganismos lácticos, mesófilos e psicotrópicos com o aumento da acidez (SANGALETTI et al., 2009) e o pH permite avaliar alterações biológicas, químicas e bioquímicas no queijo, pois afere o acúmulo de hidrogênio dissociados (AMIOT, 1991).

O queijo possui nutrientes importantes ao organismo humano, uma vez que contém carboidratos, proteínas, lipídeos, vitaminas, cálcio e fósforo (TIBA e RIBEIRO, 2010). Com a análise da composição do queijo Minas frescal, de diferentes marcas no estado do Rio de Janeiro, SILVA e FERREIRA (2010) conseguiram médias de $63 \%$ de umidade, $19 \%$ de gordura, $1,3 \%$ de carboidrato e $289 \mathrm{mg} .100 \mathrm{~g}-1$ de sódio. Queijos obtidos no estado de São Paulo foram analisados quanto ao teor de lactose e valores de 2,36 a 2,71\% foram encontrados (CARUSO e OLIVEIRA 1999).

A coagulação enzimática é o processo de formação do coágulo por meio de adição de enzimas típicas, conhecidas popularmente como coagulante ou coalho. Na coagulação do leite, para fabricação do queijo, é utilizada a enzima quimosina. A coagulação ocorre quando o coagulante hidrolisa as micelas da proteína do leite, a caseína, e em seguida acontece a formação do gel da coalhada, no qual todos os componentes do leite serão retidos na condição do gel, e esse gel que dará origem ao queijo, após diferentes processos (FIB, 2011). Por ser fresco, não existe o processo de maturação no queijo minas frescal, sendo as características de vida de prateleira, sabor e consistência do produto, influenciadas pelo processo de proteólise que acontece nas proteínas do leite para transformá-lo em queijo (WOLFSCHOONPOMBO e LIMA, 1989). Alterações, como a retirada de gordura e lactose do leite para elaboração de queijos, também podem modificar suas características sensoriais (CUNHA, 2002).

0 queijo elaborado apenas com enzima apresenta menor valor de acidez quando comparado ao queijo elaborado com a adição da cultura láctea, fato associado à produção de ácido lático pelas bactérias presentes na cultura, por meio do consumo da lactose do leite que é utilizado como matéria-prima (FURTADO et al. 1980). Sendo assim, o teor de lactose pode ser maior em queijos fabricados somente com a enzima.

A lactose é um dissacarídeo formado pela junção de D-galactose e D-glicose ligados pela ligação $\beta-1,4-$ glicosídica. É o principal carboidrato encontrado no leite, principalmente no soro do mesmo e possui baixo caráter adocicado, se comparado com outros carboidratos, sendo também um açúcar redutor e uma ótima fonte de energia para o organismo (REVISTAFIB, 2008). Por ser um dissacarídeo, a lactose deve sofrer hidrólise pela enzima lactase para originar os monossacarídeos glicose e frutose e assim serem absorvidos na corrente sanguínea. A falta desta enzima faz com que a lactose seja fermentada por microrganismos produzindo ácido e gás, gerando problemas de flatulência e diarreia (BARBOSA e ANDREAZZI, 2011). A ingestão diária para a maioria dos intolerantes a este dissacarídeo é de no máximo 12g.dia-1 (VONK et al., 2012).

A má absorção da lactose é caracterizada pela diminuição, total ou parcial, da atividade da enzima lactase. A intolerância a lactose pode ter quatro divisões, a primeira conhecida também como hipolactasia, sendo a mais comum e podendo ser adquirida hereditariamente. A secundária é causada por alterações na borda do intestino. A terceira, denominada como intolerância congênita à lactose, é percebida ainda no recémnascido. E a quarta e última é a intolerância ontogenética à lactose, se mostra como mal absorvedor da lactose (GASPARIN et al., 2010). Esta intolerância é identificada a partir de sintomas e sinais como dores abdominais, disenteria, náuseas, flatulências e vômitos, que podem ser percebidos nas horas seguintes após a ingestão de leite ou derivados (PORTO et al., 2005).

Atualmente pessoas intolerantes à lactose conseguem fazer a ingestão de leite e derivados lácteos. Essa ingestão é feita junto do consumo da enzima que realiza a hidrólise da lactose, denominada lactase. A lactase é a enzima $\beta$-D-galactosidase galactohidrolase que realiza função de hidrolase e catalisa, principalmente, a hidrólise da lactose. A hidrólise da lactose vem sendo muito utilizada para produção de derivados com baixo ou zero teor de lactose. Porém, ao acontecer a hidrólise do carboidrato as características físicas e químicas dos produtos são modificadas, pois o poder adoçante, a viscosidade, textura, corpo e paladar dos produtos são aumentadas (TREVISAN, 2008). Desse modo, as possíveis 
alterações no queijo com adição da enzima comercial lactase ou fabricado com o leite comercial sem lactose, podem ser principalmente no seu sabor, na textura e no corpo dos queijos.

\section{OBJETIVOS}

Avaliar o efeito da adição da enzima lactase no leite para a produção de queijo minas frescal, como também na massa coalhada, além da utilização do leite sem lactose comercial para formação do queijo, a fim de verificar a redução no teor de lactose do produto final. Avaliar também a influência da adição da enzima nas características físico-químicas e sensoriais do produto. Verificar se, a utilização da enzima lactase comercializada para indivíduos intolerantes reduz o teor de lactose no queijo minas frescal. Determinar se existe diferença em se adicionar a enzima lactase antes ou depois da coagulação do leite como também utilizar o leite sem lactose. Considerar se a quebra da lactose interfere na conservação do queijo por meio da acidez e pH, avaliando a adição da enzima lactase ou a utilização do leite interfere nas características sensoriais do queijo fresco.

\section{MATERIAIS E MÉTODOS}

\subsection{AQUISIÇÃO DA MATÉRIA-PRIMA E INSUMOS}

Para produção dos queijos de leite integral, considerado o tratamento controle (LL) e de leite adicionado de enzima antes (LEAN) e depois (LEAP) da coagulação foi utilizado leite pasteurizado. Para a produção do queijo elaborado com leite sem lactose (LSL), o leite utilizado foi o do tipo UHT, semi-desnatado e zero lactose. Os leites citados anteriormente e a enzima quimosina (coalho) foram comprados no comércio central de Aparecida de Goiânia. A enzima lactase da marca Lactosil também foi adquirida em uma farmácia de Aparecida de Goiânia.

\subsection{ELABORAÇÃO DO QUEIJO CONTROLE (LL)}

Para produção do queijo, cinco litros de leite pasteurizado foram aquecidos até $35^{\circ} \mathrm{C}$. Posteriormente foi adicionado $0,8 \mathrm{ml}$ de cloreto de cálcio e 4,63 $\mathrm{mL}$ de enzima quimosina.

Após a homogeneização de todos os ingredientes, o leite permaneceu em repouso por 30 minutos. Ao verificar o ponto da massa, o corte do coágulo foi realizado em cubos de $\pm 4 \mathrm{~cm}$, seguido de dessoragem parcial da massa em pano volta ao mundo. A dessoragem parcial ocorreu em torno de $50 \%$, para que fosse feito a adição de 28,5 g de cloreto de sódio, seguida de homogeneização da massa e dessoragem final. Após a dessoragem, realizou-se a enformagem e prensagem da massa, onde a soma da dessoragem e prensagem girou em torno de 4,4 L de soro. 0 queijo foi envolvido por filme de polietileno e armazenamento aconteceu em refrigeradores comerciais por 28 dias.

\subsection{ELABORAÇÃO DO QUEIJO COM ADIÇÃO DA ENZIMA LACTASE ANTES DA COAGULAÇÃO (LEAN)}

Na produção deste queijo, cinco litros de leite foram aquecimentos a $35^{\circ} \mathrm{C}$, seguido da adição de dois sachês da enzima lactase comercial (4g - 10000 FCC ALU), com intensa homogeneização e posterior repouso por 15 minutos. Após o repouso, foi adicionado 4,63 $\mathrm{mL}$ de coagulante e 1,6 $\mathrm{mL}$ de cloreto de cálcio (para garantir a firmeza da massa) no leite a $35^{\circ}$ C. Após a homogeneização dos ingredientes no leite, aconteceu o repouso por mais 30 minutos, seguidos de corte da massa em $\pm 4 \mathrm{~cm}$ de diâmetro, com dessoragem parcial, adição de cloreto de sódio, dessoragem total, enformagem, prensagem e armazenamento conforme feitos no queijo LL.

\subsection{Elaboração do queijo com adição da enzima lactase após a coagulação (LEAP)}

Cinco litros de leite pasteurizado foram aquecidos a $35^{\circ} \mathrm{C}$, adicionados de $4,63 \mathrm{~mL}$ de coagulante e $1,6 \mathrm{~mL}$ de cloreto de cálcio, homogeneizados e deixados em repouso. Após $30 \mathrm{~min}$, fez-se o corte da massa em cubos de aproximadamente $4 \mathrm{~cm}$ e adicionou-se 2 sachês de enzima lactase, seguido de uma mexedura, por 3 minutos, o que diminuiu o tamanho dos grãos. 0 segundo repouso aconteceu por 15 minutos e depois a massa ainda com o soro foi aquecida a $90^{\circ} \mathrm{C}$, para melhorar a aderência da massa obtida. 
A dessoragem parcial, a adição de cloreto de sódio, a dessoragem total, a enformagem, a prensagem e o armazenamento foram feitos conforme descrito na etapa de produção do LL.

\subsection{ELABORAÇÃO DO QUEIJO COM LEITE ZERO LACTOSE COMERCIAL (LSL)}

Foram utilizados cinco litros de leite UHT (ultra high temperature) semi-desnatado, aquecidos a $35^{\circ} \mathrm{C}$, com adição $3,2 \mathrm{~mL}$ de cloreto de cálcio e $18,51 \mathrm{~mL}$ de coagulante. 0 leite ficou em repouso por $1 \mathrm{~h}$ para coagulação. Realizou-se o corte da massa em cubos de aproximadamente $4 \mathrm{~cm}$, onde a dessoragem parcial e a adição de cloreto de sódio aconteceram conforme etapas do queijo LL. Para dessoragem total, a massa foi filtrada em pano volta ao mundo, onde permaneceu por 30 minutos. Posteriormente, foram feitas a enformagem e uma prensagem levemente da massa por 40-50 minutos, para obter em torno de 4,4 L de soro. A embalagem e armazenamento foram feitos conforme no queijo LL.

\subsection{ANÁLISE DE RENDIMENTO}

0 rendimento de cada queijo foi estimado em litros de leite necessários para a elaboração de $500 \mathrm{~g}$ de queijo ( $\mathrm{L} / \mathrm{kg}$ ). Neste caso, dividiu-se o volume de leite utilizado pela soma da massa dos queijos obtidos.

\subsection{ANÁLISE DE CUSTO}

Todos os preços dos insumos utilizados serão tabelados e as quantidades destes componentes serão transformadas em porcentagem, a fim de contabilizar o custo de produção para peças de queijos Minas frescal com 500g.

\subsection{ANÁLISES DE UMIDADE, CINZAS, LACTOSE, PH E ACIDEZ DOS QUEIJOS}

As análises de umidade, cinzas, $\mathrm{pH}$ e acidez foram realizadas a partir da metodologia do INSTITUTO ADOLFO LUTZ (2008).

\subsection{ANÁLISE DE GORDURA}

A análise de lipídios foi feita utilizando metodologia proposta por BLIGH-DYER (1959).

\subsection{ANÁLISE DE COR}

A análise de cor foi feita pelo sistema CIE, onde $\mathrm{L}^{*}$ corresponde a teor de luminosidade; $\mathrm{a}^{*}$ ao teor de vermelho e b* ao teor de amarelo, utilizando o equipamento BC-10 Baking Meter, da marca Konica Minolta (Japão), com ângulo de iluminação de $8^{\circ}$ difusa, diâmetro de medição de $8 \mathrm{~mm}$ e lâmpada de tungstênio a gás. Três repetições foram realizadas para cada amostra.

\subsection{ANÁLISE SENSORIAL}

Para a análise sensorial foi realizado um teste afetivo de aceitação por 60 provadores não treinados, que eram alunos e servidores do Instituto Federal de Goiás/Câmpus Aparecida de Goiânia. Utilizou-se para o teste, escala hedônica de nove pontos (CHAVES e SPROESSER, 2002) com avaliação da cor, textura, aparência, sabor e aroma dos queijos, que foram analisados monodicamente.

\subsection{DELINEAMENTO EXPERIMENTAL}

Foi empregado o delineamento inteiramente casualizado onde os dados foram submetidos à análise de variância, e as comparações entre as médias dos tratamentos foram realizadas por meio do teste Tukey a $5 \%$ de probabilidade, mediante uso do software R (2015). 


\section{RESULTADOS E DISCUSSÃO}

Na Tabela 1 estão apresentados os custos de cada queijo, com peso de 500g. A adição da enzima encarece o produto em $45 \%$ enquanto a fabricação de queijo com leite sem lactose, $47 \%$.

Tabela 1. Custo para produção de 500g, em reais $(0$ dos queijos elaborados a partir do leite com lactose (LL), leite adicionado de lactase antes (LEAN) e após (LEAP) a coagulação e leite sem lactose comercial (LSL)

\begin{tabular}{|c|c|c|c|c|}
\hline \multirow{2}{*}{$\begin{array}{l}\text { Ingredientes - formulação para } 500 \mathrm{~g} \text { de } \\
\text { queijo }\end{array}$} & \multicolumn{4}{|c|}{ Tratamentos - valores em R\$ } \\
\hline & LL & LEAN & LEAP & LSL \\
\hline Leite pasteurizado & 15,00 & 15,00 & 15,00 & - \\
\hline Leite UHT sem lactose & - & - & - & 28,00 \\
\hline Coalho & 0,16 & 0,16 & 0,16 & 0,48 \\
\hline Cloreto de cálcio & 0,007 & 0,007 & 0,007 & 0,035 \\
\hline Sal & 0,057 & 0,057 & 0,057 & 0,057 \\
\hline Enzima Lactase & - & 12,50 & 12,50 & - \\
\hline Total & 15,22 & 27,72 & 27,72 & 28,57 \\
\hline
\end{tabular}

Na Tabela 2 estão apresentados os resultados de rendimento, umidade, cinzas e gordura dos queijos elaborados neste experimento. 0 queijo adicionado de enzima antes da coagulação obteve maior rendimento $(\mathrm{P}<0,05)$ seguido dos tratamentos LEAP, LL e LSL. 0 queijo elaborado do leite sem lactose comercial foi o que obteve menor rendimento, fato que pode estar associado ao seu menor teor de gordura e maior teor de água.

Tabela 2. Resultados de rendimento e médias das análises de umidade, cinzas e gordura dos queijos elaborados a partir do leite com lactose (LL), leite adicionado de lactase antes (LEAN) e após (LEAP) a coagulação e leite sem lactose comercial (LSL)

\begin{tabular}{|c|c|c|c|c|c|c|}
\hline \multirow{2}{*}{ Análises } & \multicolumn{4}{|c|}{ Queijo } & \multicolumn{2}{|c|}{ Parâmetros } \\
\hline & LL & LEAN & LEAP & LSL & $\mathrm{p}$ & $\mathrm{CV}$ \\
\hline Rendimento (\%) & $10,14^{*} \mathrm{a}$ & $10,81 b$ & $11,57 \mathrm{c}$ & $7,61 d$ & $<0,001$ & 0,98 \\
\hline Umidade (\%) & $58,09 \mathrm{~b}$ & $50,65 d$ & $54,01 \mathrm{c}$ & $64,93 a$ & $<0,001$ & 0,95 \\
\hline Cinzas (\%) & $2,71 d$ & $3,57 \mathrm{c}$ & $3,83 b$ & $5,30 a$ & $<0,001$ & 0,68 \\
\hline Gordura (\%) & $19,98 b$ & $22,27 a$ & $15,43 c$ & $7,01 \mathrm{~d}$ & $<0,001$ & 3,04 \\
\hline
\end{tabular}

*Médias seguidas de letras iguais na mesma linha não diferiram estatisticamente a 5\% de probabilidade pelo teste de Tukey.

Para a análise de umidade houve diferença significativa $(\mathrm{P}<0,01)$ entre os queijos elaborados. 0 queijo fabricado a partir do leite sem lactose obteve maior teor de umidade, enquanto o queijo produzido por meio da adição da enzima lactase comercial antes da coagulação, menor valor.

Maior teor de umidade do queijo LSL pode ser justificado em queijo fabricado a partir de leites que sofreram ação de altas temperaturas, pois segundo FOX (1989) a $\alpha$-lactoglobulina, que é uma proteína do soro que se desnatura a temperaturas superiores a $70^{\circ} \mathrm{C}$ e atua sobre a $\kappa$-caseína, dificulta a ação do coagulante, o que consequentemente aumenta o tempo de coagulação e a umidade do queijo. Esse queijo foi elaborado com leite UHT, cujo processo de tratamento térmico utiliza temperaturas superiores a $100^{\circ} \mathrm{C}$. Também associado à interação entre as proteínas citadas acima, está a fragilidade da massa do queijo LSL, quando comparada as demais massas obtidas neste trabalho, que não utilizaram temperaturas superiores a $80^{\circ} \mathrm{C}$ anteriormente ao processo de coagulação.

Quanto ao teor de umidade dos demais queijos, percebe-se pela Tabela 2 que, o tratamento LEAN foi o de menor umidade e com maior teor de gordura. Essas características mostram que o queijo fabricado com adição da enzima lactase antes da coagulação conseguiu reter a gordura do leite de forma mais eficiente, obtendo assim um rendimento intermediário quando comparado aos demais. Já o queijo fabricado com a adição da enzima após a coagulação obteve umidade intermediária, menor teor de gordura e maior 
rendimento. Este queijo passou pelo processo de mexedura mais rigorosa após a coagulação, para a mistura da enzima, o que afetou no tamanho e retenção da gordura no coágulo formado.

0 aquecimento a $80^{\circ} \mathrm{C}$ para maior agregação da massa, feito no tratamento LEAP também diminuiu o teor de umidade do queijo em relação ao padrão e pode ter gerado um coágulo mais firme, favorecendo o maior rendimento deste queijo. Segundo CAVALCANTE et al. (2007) a massa que passa pelo processo de mexedura com aquecimento, após o corte da coalhada, gera grãos com consistência mais firme e brilhante. Já no queijo padrão, denominado de LL, foi encontrado maior teor de umidade e menor rendimento entre os queijos elaborados com leite pasteurizado.

0 teor de cinzas diferiu entre os tratamentos $(\mathrm{P}<0,05)$. Para HAUTRIVE et al. $(2012)$ a determinação das cinzas consiste em uma análise inicial para o conteúdo de minerais presentes na amostra. No presente trabalho, o queijo LSL obteve maior teor de cinzas, seguido dos queijos LEAP, LEAN e LL. Este fato pode estar associado a quantidade de cloreto de cálcio adicionada, uma vez que este ingrediente disponibiliza o cálcio para melhorar a formação da coalhada. Como a adição de cloreto de cálcio foi duas vezes maior nos tratamentos LEAN e LEAP e quatro vezes mais no LSL, em relação ao queijo padrão, considera-se que o teor de cinzas foi proporcional a adição do mesmo.

A adição de cloreto de cálcio também pode ter definido o teor de umidade e rendimento nos queijos que utilizaram leites pasteurizados, visto que, o queijo de maior rendimento e de umidade intermediária foi o que obteve maior teor de cinzas e o queijo com menor teor de umidade e com segundo maior teor de cinzas, obteve também o segundo maior rendimento. No leite pasteurizado a adição de cloreto de cálcio é realizada para devolver o cálcio que foi solubilizado durante o processo de pasteurização, sendo responsável pela a firmeza da coalhada (PAULA et al., 2009). O cloreto de cálcio também é responsável por evitar a perda de sólidos no soro e melhorar a expulsão do soro (GONÇALVES et al., 2010).

Quanto a gordura, tem-se que todos os tratamentos diferiram entre si $(\mathrm{P}<0,05)$. 0 LEAN obteve maior valor de gordura, seguido pelos LL, LEAP e LSL. Considerando que no coágulo para formação do queijo a gordura está retida numa rede proteica com ligações de fosfato de cálcio (DIAMANTINO e PENNA, 2011) e que os queijos elaborados de leite pasteurizado utilizaram o mesmo lote deste tipo de leite é possível inferir que o tratamento LEAN conseguiu reter maior quantidade de gordura em relação ao queijo padrão e este fato está associado a quantidade de cloreto de cálcio que foi utilizada para o LEAN em relação ao LL.

Em relação ao LEAP conter menor teor de gordura quando comparado ao LL pode ser devido ao processamento do LEAP, que mesmo utilizando o dobro de cloreto de cálcio, foi preciso intensa mexedura após a coagulação, para misturar a lactase ao coágulo, o que diminuiu drasticamente o tamanho dos grãos formados e consequentemente maior teor de gordura foi transferida para o soro deste queijo. Segundo VIOTTO e CUNHA (2006) a recuperação do teor de gordura no queijo pode ter como interferente a manipulação mecânica durante o processo e para CIÊNCIA DO LEITE (2017) a rapidez do corte, juntamente com a intensidade da agitação e o tamanho final dos grãos têm forte influência nas perdas de gordura e proteína do coágulo para o soro de leite.

A fragilidade da massa do tratamento LSL, gerada pela utilização do leite UHT, e o baixo teor de gordura desse leite, considerado semi-desnatado, também explicam o menor teor de gordura do queijo LSL em relação aos demais tratamentos.

Na Tabela 3 encontram-se os resultados dos parâmetros de cor dos queijos analisados.

Tabela 3. Médias dos parâmetros de cor $\left(L^{*}, a^{*}, b^{*}\right)$ dos queijos elaborados a partir do leite com lactose (LL), leite adicionado de lactase antes (LEAN) e após (LEAP) a coagulação e leite sem lactose comercial (LSL)

\begin{tabular}{|c|c|c|c|c|c|c|}
\hline \multirow{2}{*}{ Parâmetros de cor } & \multicolumn{4}{|c|}{ Queijo } & \multicolumn{2}{|c|}{ Parâmetros } \\
\hline & $\mathrm{LL}$ & LEAN & LEAP & LSL & $\mathrm{p}$ & $\mathrm{CV}$ \\
\hline $\mathrm{L}$ & $87,87 * a b$ & $90,30 a$ & $82,77 b c$ & $78,57 c$ & $<0.001$ & 3,31 \\
\hline a & $-0,43 b$ & $-1,47 c$ & $-0,17 b$ & $4,33^{\mathfrak{a}}$ & $<0.001$ & 30,99 \\
\hline $\mathrm{b}$ & $15,17 \mathrm{ab}$ & $13,57 b$ & $15,72 a$ & $11,02 c$ & $<0.001$ & 5,70 \\
\hline
\end{tabular}

*Médias seguidas de letras iguais na mesma linha não diferiram estatisticamente a $5 \%$ de probabilidade pelo teste de Tukey. 
0 parâmetro $\mathrm{L}^{*}$, que se refere a luminosidade da amostra, diferiu significativamente entre os tratamentos, sendo que o LEAN não diferiu do LL, como também o LEAP não diferiu do LL nem do LSL. Para o parâmetro $b^{*}$ houve diferença significativa $(P<0,01)$ entre os tratamentos. O queijo LEAP não diferiu do LL, já o LEAN diferiu em pequena quantidade do LL, demonstrando que os processamentos adotados para os queijos elaborados de leite pasteurizado não promoveram a diferença entre o queijo padrão e os queijos adicionados de enzima, quando se analisa os critérios de luminosidade e tom de amarelo dos queijos.

Para o parâmetro $\mathrm{a}^{*}$ também houve diferença significativa $(\mathrm{P}<0,01)$ e o maior valor foi encontrado no queijo LSL. Esse resultado foi encontrado pelo fato deste queijo possuir coloração rosa, transferida do leite UHT utilizado como matéria-prima para este tratamento. A coloração rosa encontrada neste leite é devido a reação de maillard que acontece na presença de açúcares redutores, proteína e temperatura.

As bactérias láticas são responsáveis por fermentarem o carboidrato presente no leite, ou seja, a lactose. Como resultado da fermentação, tem-se o ácido lático, que acarreta um aumento da acidez, conforme Figura 1 e por consequência uma diminuição do pH, demonstrado na Figura 2 (ALEXANDRE et al., 2002). Ao analisar as Figuras 1 - A e 1 - B foi possível perceber exatamente esse aspecto, a acidez aumentou e o pH diminuiu, pois, com o passar do tempo de armazenamento para realização das análises, a lactose do queijo (Figura 1 - C) foi sendo fermentada (ANDREATTA, 2006). Com a análise dos gráficos do decréscimo de lactose nos queijos nota-se que o LL teve o maior decréscimo de lactose durante o decorrer das análises, considerando que o elevado teor de lactose pode ter propiciado o maior desenvolvimento microbiano. Nos outros tipos de queijos não houve um decréscimo tão expressivo quando comparado ao LL. Os queijos LEAN, LEAP e LSL que são os queijos com baixo teor de lactose não apresentaram teor de lactose igual a zero ao final dos dias de análises, sendo o LEAP e LEAN os mais próximos de zero, com $0,2 \%$ e $0,3 \%$ de lactose, respectivamente.

Figura 1. Evolução da acidez (A), pH (B) e lactose (C) para os queijos elaborados com leite integral (LL), leite adicionado de enzima lactase antes da coagulação (LEAN), leite adicionado de enzima lactase após a coagulação (LEAP), e leite sem lactose comercial (LSL).

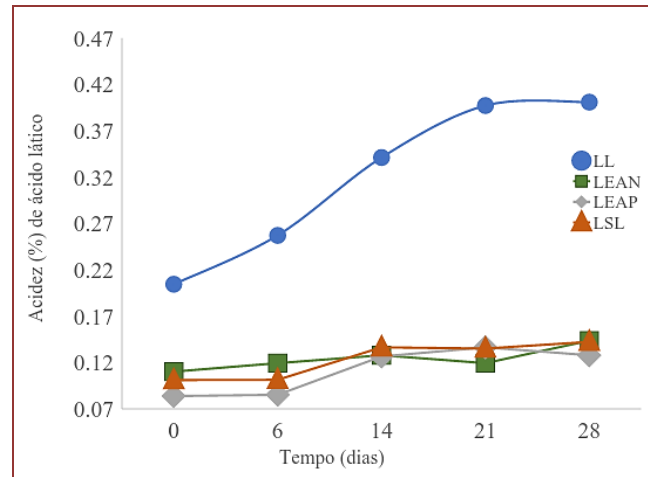

(A)

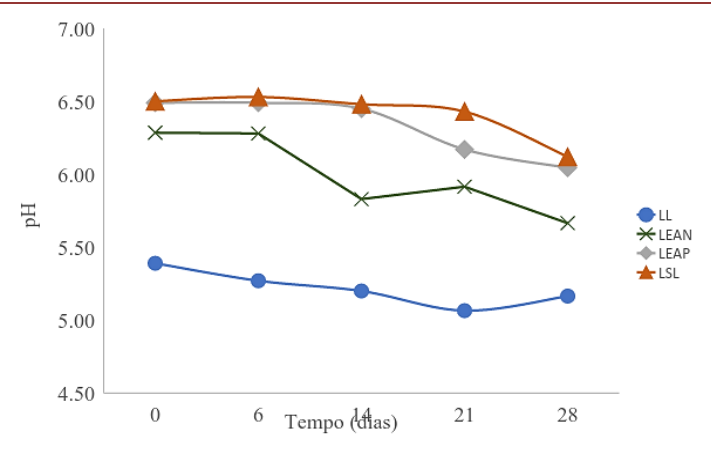

(B)

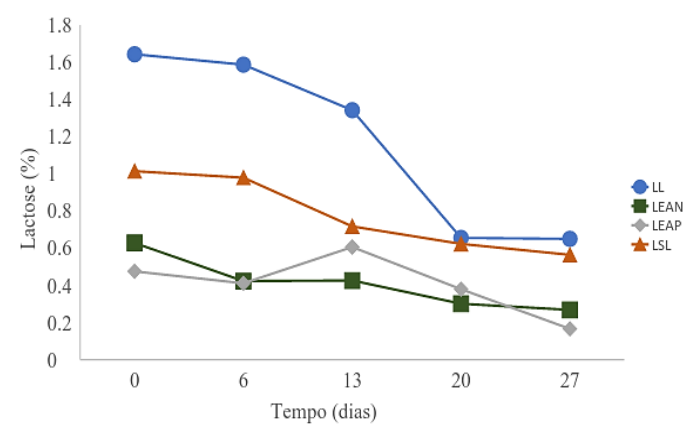

(C) 
Um dos possíveis motivos para o LEAP apresentar menor teor de lactose, desde o início das análises, se comparado com LEAN e LSL, se dá pelo seu preparo, pois, o LEAP foi o queijo que necessitou aquecimento para melhor formação da massa, com isso a lactase atuou melhor, por conta da sua faixa de temperatura ótima para atuação que varia entre $30^{\circ}$ e $60^{\circ} \mathrm{C}$ (TREVISAN, 2008). Já o leite UHT, que foi o utilizado para o LSL, pode ter tido uma inativação enzimática da lactase mais rápida e com isso menor tempo de atuação, gerando maior teor de lactose em relação aos que tiveram enzimas adicionadas. Para verificar se houve diferença significativa entre os conteúdos de acidez, pH e lactose dos queijos foi realizada análise estatísticas destas características nos períodos de zero, 14 e 28 dias de fabricação (Tabela 4). Para todas as análises, em diferentes tempos, houve diferença significativa $(\mathrm{P}<0,05)$ entre os tratamentos. A acidez do queijo LL foi maior que as dos demais nos três períodos analisados, o que é demonstrado na distância da curva (Figura 1) obtida para acidez deste queijo em comparação aos demais.

Para o pH, o tratamento LL obteve menor valor nos tempos zero e 14 dias em relação aos demais tratamentos. Já em 28 dias o LEAN não diferiu $(P>0,05)$ do LL. Para a determinação de lactose nos tempos 0 e 28 dias, houve diferença significativa $(\mathrm{P}<0,05)$ entre os tratamentos. A acidez do queijo LL foi maior que as dos demais nos três períodos analisados, o que é demonstrado na distância da curva (Figura 1 - A) obtida para acidez deste queijo em comparação aos demais.

O queijo que apresentou maior teor de ácido lático foi o que, no intervalo de 28 dias obteve pH mais baixo entre as quatro variações de queijos e o maior teor de ácido lático. Com estes resultados é possível perceber uma ligação direta com o teor de lactose, a fermentação lática e o desenvolvimento de microrganismos. A partir disso, é possível perceber que queijos com menores percentuais de lactose, além de atenderem a um mercado importante de intolerantes a este açúcar, provavelmente também apresentam maior tempo de prateleira.

Tabela 4. Médias de acidez, pH e lactose nos tempos zero, 15 e 28 dias, dos queijos elaborados a partir do leite com lactose (LL), leite adicionado de lactase antes (LEAN) e após (LEAP) a coagulação e leite sem lactose comercial (LSL)

\begin{tabular}{|c|c|c|c|c|c|c|}
\hline \multirow{2}{*}{ Parâmetros de cor } & \multicolumn{4}{|c|}{ Queijo } & \multicolumn{2}{|c|}{ Parâmetros } \\
\hline & LL & LEAN & LEAP & LSL & $\mathrm{p}$ & $\mathrm{CV}$ \\
\hline \multicolumn{7}{|c|}{ Tempo Zero dias } \\
\hline Acidez & $0,20 \mathrm{a}$ & $0,11 b$ & $0,08 \mathrm{c}$ & $0,10 \mathrm{bc}$ & $<0.001$ & 4,54 \\
\hline $\mathrm{pH}$ & $5,39 a$ & $6,28 b$ & $6,49 \mathrm{~b}$ & $6,49 \mathrm{~b}$ & 0.001 & 1,62 \\
\hline Lactose & $1,62 \mathrm{a}$ & $0,62 b$ & $0,45 c$ & $1,01 d$ & $<0.001$ & 2,54 \\
\hline \multicolumn{7}{|c|}{ Tempo 14 dias } \\
\hline Acidez & $0,34 a$ & $0,14 b$ & $0,13 \mathrm{~b}$ & $0,14 \mathrm{~b}$ & $<0.001$ & 6,43 \\
\hline $\mathrm{pH}$ & $5,20 \mathrm{a}$ & $5,83 b$ & $6,45 c$ & $6,48 c$ & $<0.001$ & $6,48 c$ \\
\hline Lactose & $1,37 a$ & $0,43 b$ & $0,65 c$ & $0,76 c$ & $<0.001$ & 6,11 \\
\hline \multicolumn{7}{|c|}{ Tempo 28 dias } \\
\hline Acidez & $0,40 \mathrm{a}$ & $0,14 \mathrm{~b}$ & $0,13 \mathrm{~b}$ & $0,14 \mathrm{~b}$ & 0.003 & 15,96 \\
\hline $\mathrm{pH}$ & $5,16 a$ & $5,66 a b$ & $6,04 c$ & $6,12 c$ & 0.006 & 2,27 \\
\hline Lactose & $0,67 a$ & $0,27 b$ & $0,17 c$ & $0,58 d$ & $<0.001$ & 5,34 \\
\hline
\end{tabular}

*Médias seguidas de letras iguais na mesma linha não diferiram estatisticamente a 5\% de probabilidade pelo teste de Tukey.

Os resultados da aceitação sensorial estão disponíveis na Tabela 5, onde é possível perceber que a aceitabilidade para a aparência, textura e aroma foram estatisticamente iguais entre os queijos LL, LEAN e LEAP. Já para o sabor as médias recebidas para o LEAN foi estatisticamente igual ao LL e a média do LEAP não diferiu do LEAN e LSL. 
Tabela 5. Médias da análise sensorial dos queijos elaborados a partir do leite com lactose (LL), leite adicionado de lactase antes (LEAN) e após (LEAP) a coagulação e leite sem lactose comercial (LSL)

\begin{tabular}{|c|c|c|c|c|c|}
\hline \multirow{2}{*}{$\begin{array}{c}\text { Análise sensorial } \\
\text { Aceitação }\end{array}$} & LL & LEAN & LEAP & LSL & Parâmetro \\
\hline Aparência & $8,46 * a$ & $8,38 \mathrm{a}$ & $8,01 \mathrm{a}$ & $4,67 \mathrm{~b}$ & $<0,001$ \\
\hline Textura & $8,19 \mathrm{a}$ & $8,17 \mathrm{a}$ & $7,60 \mathrm{a}$ & $4,38 \mathrm{~b}$ & $<0,001$ \\
\hline Aroma & $7,86 \mathrm{a}$ & $7,75 \mathrm{a}$ & $7,44 \mathrm{ab}$ & $6,94 \mathrm{~b}$ & 0,0018 \\
\hline Sabor & $7,95 \mathrm{a}$ & $7,45 \mathrm{ab}$ & $6,83 \mathrm{~b}$ & $5,35 \mathrm{c}$ & $<0,001$ \\
\hline
\end{tabular}

*Médias seguidas de letras iguais na mesma linha não diferiram estatisticamente a $5 \%$ de probabilidade pelo teste de Tukey.

No queijo LSL, aspectos como aparência e textura foram os que mais se distanciaram dos outros tipos, pois foi a massa que necessitou de maior adição de coalho e cloreto de cálcio e mesmo com maior adição, a massa continuou com baixas condições de manipulação, resultando em um queijo mole e de baixa consistência.

O queijo com baixo teor de lactose de maior aceitação foi o adicionado de enzima antes da coagulação e que possui os atributos avaliados sem diferença significativa do queijo com lactose.

\section{CONCLUSÃO}

Com os resultados obtidos nos queijos sem lactose foi possível perceber que a enzima comercializada em farmácias adicionada nos queijos teve melhor atuação se comparada à enzima utilizada na indústria da marca do leite utilizado para o preparo do queijo sem lactose e que se adicionada antes da coagulação as características do queijo com reduzido teor de lactose se aproximam mais do queijo controle (com lactose).

Ressalta-se ainda, o papel da lactose como substrato fermentativo de bactérias lácteas, o que interfere na conservação dos queijos, já que altera as curvas de acidez e pH nos queijos. Em síntese, é possível ter uma maior vida útil em queijos com menor teor de lactose.

Apesar da elevação do custo, foi possível produzir queijo com baixo conteúdo de lactose com a mesma aceitação sensorial do queijo padrão.

\section{REFERÊNCIAS}

[1] ALEXANDRE, D.P. et al. Atividade antimicrobiana de bactérias lácticas isoladas de queijo-de-minas artesanal do Serro (MG) frente a microrganismos indicadores. Arquivos Brasileiros de Medicina Veterinária e Zootecnia. v. 54. n. 4, p. 424-428, 2002.

[2] AMIOT, J. et al. Ciencia y tecnologia de la leche. Zaragoza: Acribia, 1991.

[3] ANDREATTA, E. Avaliação da qualidade dos queijos Minas Frescal e tipo Mussarela produzidos com leite contendo diferentes níveis de células somáticas. 2006. 110 f. Tese (Doutorado em Qualidade e Produtividade Animal) - Faculdade de Zootecnia e Engenharia de Alimentos, Universidade de São Paulo, Pirassununga.

[4] BARBOSA, C. R.; ANDREAZZI, M. A. Intolerância à lactose e suas consequências no metabolismo do cálcio. Revista do Instituto de Laticínio Cândido Tostes, Juiz de Fora, v.64, n366, p.12-21, 2011.

[5] BLIGH EG, DYER WJ. A rapid method of total lipid extraction and purification. Canadian Journal of Biochemistry and Physiology. 1959;27(8):911-17.

[6] BRASIL. Ministério da Agricultura, Pecuária e Abastecimento. Portaria no352/1997. Regulamento técnico de identidade e qualidade de queijos. Diário Oficial da República Federativa do Brasil, Brasília, 04 set. 1997. Seção 1, p. 19684.

[7] CARUSO E. C.; OLIVEIRA, A. J. Quantificação de lactose em queijos minas frescal. Nota. Scientia Agricola. Piracicaba, v.56, n.1, p. 243-246, 1999.

[8] CAVALCANTE, J. F. M. et al. Processamento do queijo coalho regional empregando leite pasteurizado e cultura lática endógena. Ciência e Tecnologia de Alimentos. v. 27. n 1, p. 205 - 214, 2007. 
[9] CHAVES, Jose. B. P.; SPROESSER, Renato L. Práticas de laboratório e análise sensorial de alimentos e bebidas. Vicosa: UFV, 2002.

[10] CIÊNCIA DO LEITE. O Rendimento na fabricação de queijos: Métodos para avaliação e comparação: Parte I. Disponível em: http://cienciadoleite.com.br/noticia/2808/o-rendimento-na-fabricacao-de-queijos-metodos-paraavaliacao-e-comparacao--parte-i. Acesso em: 08, Mai, 2017.

[11] CUNHA, C.R. da et al. Efeito do fator de concentração do retentado o rendimento de queijo minas frescal de baixo teor de gordura fabricado por ultrafiltração. Ciênc. Tecnol. Aliment., Campinas, v. 22, n. 1, p. 76-81, Jan. 2002.

[12] DIAMANTINO, I. N. PENNA, A. L. B. Efeito da utilização de substitutos de gordura em queijos light. Revista do Instituto Adolfo Lutz. v. 70. n. 3, p. 258-267, 2011.

[13] FIB. Dossiê Enzimas: A evolução das enzimas coagulantes. Food Ingredients Brasil. n. 16, p. 38-39, 2011.

[14] FOX, P. F. Proteolysis during cheese manufacturing and ripening. Journal of Dairy Science. v. 72. n. 6, p. 1379 - 1400, Jun, 1989.

[15] FRADE, Pedro. Queijo minas, um patrimônio da gastronomia mineira. Disponível em: http://www.petitgastro.com.br/queijo-minas-um-patrimonio-da-gastronomia-mineira/. Acesso em: 21, jul, 2016.

[16] FURTADO, M. M.; SOUZA, H. M.; MUNCK, A. V. A fabricação do queijo Minas frescal sem o emprego de culturas lácticas. Revista do Instituto de Laticínios Cândido Tostes, v. 35, n. 207, p. 15-21, 1980.

[17] GASPARIN, F. S. R.; TELES, J.M.; ARAÚJO, S. C. Alergia à proteína do leite de vaca versus intolerância à lactose: as diferenças e semelhanças. Revista Saúde e Pesquisa, v. 3, n. 1, p. 107-114, jan/abr. 2010 - ISSN 1983-1870.

[18] GONÇALVES, C. A. A. et al. Efeito do uso de cloreto de cálcio nos aspectos sensoriais do queijo minas frescal. Enciclopédia Biosfera, v. 6, n. 10, p. 1 - 4, 2010.

[19] HAUTRIVE, T. P.; MARQUES, A. C.; KUBOTA, E. H. Avaliação da composição centesimal, Colesterol e perfil de ácidos graxos de cortes cárneos comerciais de avestruz, suíno, bovino e frango. Alimentos e Nutrição, v. 23 n.2 p. 327 334. Jan, 2012.

[20] INSTITUTO ADOLFO LUTZ. Métodos físico-químicos para análise de alimentos. São Paulo: Intituto Adolfo Lutz, 2008. 1020p.

[21] PAULA, J. C. J.; CARVALHO, A. F.; FURTADO, M. M. Princípios básicos de fabricação de queijo: do histórico à salga. Revista do Instituto de Laticínios Cândido Tostes. v. 64. n 367, p. 19-25, 2009.

[22] PORTO, C. P. C.; THOFEHRN. M. B.; SOUSA, A. S.; CECAGNO, D. Experiência vivenciada por mães de crianças com intolerância à lactose. Família, Saúde e Desenvolvimento. Curitiba, v.7, n.3, p.250-256, set./dez. 2005.

[23] R DEVELOPMENT CORE TEAM. R - A language and environment for statistical computing. Vienna, Austria: $\mathrm{R}$ Foundation for Statistical Computing, 2015. Disponivel em <http://www.R-project. org>. Acesso em: 14 jun. 2017.

[24] REVISTA FIB. Adoçantes calóricos e não calóricos: parte I. 2008. Disponível em: http://www.revistafi.com/materias/58.pdf. Acesso em: 06, mar, 2017.

[25] SANGALETTI, N. P.; et al. Estudo da vida útil de queijo Minas. Ciência e Tecnologia de Alimentos, Campinas, v.29, n.2, p 262-269, 2009.

[26] SILVA, F. T. Queijo minas frescal. 2005. EMBRAPA Parque Estação Biológica. Brasília, DF.

[27] SILVA, L. F. M.; FERREIRA, K. S. Avaliação de rotulagem nutricional, composição química e valor energético de queijo minas frescal, queijo minas frescal "light" e ricota. Alimentos e Nutrição, Araraquara, v. 21, n. 3, p. 438, 2010.

[28] TIBA, D.S.; RIBEIRO, E. P.; Avaliação das características físico-químicas de queijo minas frescal, produzido a partir de retentados obtidos por ultra filtração de leite, enriquecido em fibras, minerais e vitaminas, destinado a idosos. In: 2.o Seminário Mauá de Iniciação Científica - Escola de Engenharia Mauá, 2010, São Paulo. Anais Eletrônicos 2.- Seminário Mauá de Iniciação Científica. São Paulo: USP, 2010.

[29] TREVISAN, Ana Paula. Influência de diferentes concentrações de enzimas lactase e temperatura sobre a hidrólise da lactose em leite pasteurizado. 2008. 60f. Dissertação (Mestrado em Ciência e Tecnologia dos Alimentos) Universidade Federal de Santa Maria, Rio Grande do Sul.

[30] VIOTTO, W.H., CUNHA, C.R. Teor de sólidos do leite e rendimento industrial. In: MESQUITA, A.J., DURR, J.W., COELHO, K.O. Perspectivas e avanços da qualidade do leite no Brasil. Goiânia: Talento, 2006, v.1, p. 241-258.

[31] VONK, R. J. et al. 2012. Probiotics and Lactose Intolerance. Chapter 7. InTech Open, 7, 149-160.

[32] WOLFSCHOON-POMBO, A. F. et al. Alterações no queijo Minas Frescal durante o período de armazenamento. Revista do Instituto de Laticínios Cândido Tostes, v. 39, n. 233, p. 3-9, 1984. 


\title{
Capítulo 16
}

\section{Percepção dos consumidores sobre a qualidade dos produtos lácteos}

\author{
Adriana Soraya Araújo \\ Dáffyne Kelly Silva Costa Oliveira \\ Ilana Morgana Ferreira Araújo dos Santos \\ Maria de Fátima de Sousa Cascaes
}

Resumo: 0 presente artigo teve como finalidade analisar a percepção de qualidade pelos consumidores de produtos lácteos além de observar se há o consumo de leite e derivados sem inspeção sanitária e os riscos à saúde humana associada ao consumo desses produtos. As indústrias estão reconhecendo a importância de entender o comportamento do consumidor, pois a necessidade de entender o comportamento do consumidor tem sido alvo de pesquisas para obter maior sucesso nas tomadas de decisão. A qualidade, em geral, e os atributos de segurança do alimento são importantes elementos para a tomada de decisão dos consumidores. Esta pesquisa foi desenvolvida a partir da revisão teórica de modelos de qualidade percebida nos alimentos, acrescidos de informações específicas assim como a análise dos questionários aplicados aos consumidores. Dentre os mecanismos que podem contribuir para a percepção da qualidade do produto por parte dos consumidores, Pode-se destacar a imagem positiva da marca e a reputação da empresa, características organolépticas, atribuição de valor e praticidade.

Palavras-chave: qualidade, produtos lácteos, comportamento do consumidor. 


\section{INTRODUÇÃO}

O leite consiste em uma solução que contém sais, carboidratos e proteínas dispersos em fase aquosa, lóbulos de gordura em emulsão e partículas hidratadas de proteína em suspensão coloidal, o conteúdo vitamínico do leite é de grande importância nutricional, pois todas as vitaminas necessárias ao ser humano são encontradas em sua composição, como a vitamina $\mathrm{A}$, as do complexo B, ácido pantotênico, niacina, biotina e outras, mas apresenta escassez de vitamina C. Além disso, os minerais, ainda que presentes em pequenas quantidades complementem esse alimento como fonte rica em compostos essenciais à manutenção da saúde e em biodisponibilidade de nutrientes (LOBATO, 2005).

A presença desse alimento na dieta ocorre, principalmente, pelo fato de ser fonte de proteínas e de minerais essenciais à promoção do crescimento e manutenção da vida para o ser humano. Os benefícios oferecidos pelo consumo de leite e derivados, como parte de uma dieta saudável e balanceada, têm sido amplamente discutidos e estabelecidos.

Diante destas afirmações FARINA et al., (2005) diz que a bovinocultura de leite e os segmentos processadores de produtos lácteos exercem um papel fundamental no desenvolvimento socioeconômico brasileiro. 0 setor lácteo no Brasil, durante as décadas de 1970 e 1980, foi ajudado por órgãos públicos de comercialização, basicamente por meio da definição de preços, tendo em vista à geração de excedentes ao produtor. 0 protecionismo resultou em preços de produtos lácteos ao consumidor maiores do que os preços internacionais e no desestímulo por investimentos em qualidade e em produtividade dos sistemas produtivos.

No entanto o mercado de leite no Brasil vem se transformando nas últimas décadas, devido ao surgimento de novas tecnologias capazes de processar e transformar o leite em um produto final que atenda as exigências dos consumidores. Desta maneira, existem vários tipos de leites e derivados disponíveis para o consumo, tanto com prazo de validade curto (três a seis dias sob refrigeração) como prazos mais longos. As condições favoráveis de mercado permitiram a implementação do Programa de Melhoria da Qualidade do Leite e da Instrução Normativa no. . 51, que estabeleceram critérios para a produção, identidade e qualidade do leite. Os principais elementos do programa de monitoramento da qualidade e segurança do leite foram à obrigatoriedade de realização dos testes de contagem bacteriana total, de células somáticas e de resíduos antibióticos em laboratórios credenciados, e a refrigeração e coletam a granel da matéria prima nas propriedades rurais produtoras.

A qualidade dos alimentos tornou-se um atributo fundamental para a transformação dos sistemas agroalimentares e determinante para a competitividade da indústria de laticínios (FARINA et al., 2005). Os investimentos em controle de qualidade no processamento de alimentos lácteos se justificam basicamente por três razões: a. garantia de segurança alimentar; a otimização do uso de recursos; e a conquista e manutenção de mercados consumidores (DÜRR, 2006). A qualidade pode ser identificada por meio de características que assumem dimensões objetivas e subjetivas. No entanto, para a identificação de um parâmetro de qualidade nos laticínios se faz necessária à especificação do conceito (TOLEDO, 2001). Garvin (1987) apresenta uma síntese das abordagens de gestão da qualidade, vinculadas fundamentalmente ao desenvolvimento de produtos e processos, propondo oito dimensões de qualidade que podem servir como um modelo para análise estratégica: desempenho; recursos; confiabilidade; conformidade; durabilidade; manutenção; estética; e qualidade percebida.

De acordo com MARTINS (2005) nos últimos anos, a população brasileira, vem se preocupando mais com a qualidade dos alimentos que chegam à sua mesa. Essa qualidade está associada com a observação de alguns aspectos sensoriais como sabor, odor, cor e viscosidade. No caso do leite, além destes aspectos, a questão sanitária, sua adequação prática e tempo de vida de prateleira do produto também são observados. Apesar de todas as inovações tecnológicas observadas nestas últimas décadas, é necessário entender qual a percepção do consumidor em relação a isso, ou seja, se o consumidor consegue entender as diferenças entre os produtos oferecidos, bem como suas características próprias.

A qualidade percebida é uma dimensão subjetiva baseada na inferência dos consumidores por meio de informações presentes no produto e no ambiente de compra. Esta é o resultado de um processo de percepção. 0 juízo sobre a qualidade de um alimento é formado a partir de características visíveis ou invisíveis, as quais podem ser experimentadas, ou apenas associadas com o produto avaliado.

Pensando assim, a presente pesquisa pretende avaliar por meio de questionário, a posição dos consumidores de produtos lácteos na área de São Luís do Maranhão a fim de Investigar o consumo, os principais tipos de produtos adquiridos, os aspectos de qualidade levados em consideração na hora da compra, bem como o nível de informação dos mesmos, gerando elementos para um entendimento mais 
amplo sobre o mercado consumidor desses produtos. Além de estimular nesses consumidores a compra, o uso consciente e com qualidade a fim de estabelecer a manutenção da saúde da clientela.

\section{MATERIAL E MÉTODOS}

Para a realização desta pesquisa foi utilizado para o embasamento teórico materiais bibliográficos de artigos relacionados à qualidade dos produtos lácteos e os padrões para manutenção da qualidade na produção, também foi utilizado como instrumento para a coleta de dados um questionário aplicado nos dias 15 à 20 de maio de 2016 na cidade de São Luís do Maranhão há um grupo de trinta pessoas, este foi dividido em duas partes. Na primeira parte, denominada "perfil do consumidor", foram incluídas perguntas sobre sexo, faixa etária, escolaridade do consumidor e faixa de renda familiar. A pesquisa incluiu entrevistados com idade superior a 18 anos, considerando que esta seria uma idade limite, a partir da qual o entrevistado já exibiria poder de decisão na hora da compra de alimentos. A segunda parte, denominada "características do consumidor", incluiu perguntas de múltipla escolha e discursivas a fim de se estabelecer quais as preferencias dos consumidores e a preocupação com a qualidade. Estas foram analisadas através de porcentagens e gráficos comparados há outras pesquisas de outros estados.

\section{RESULTADOS E DISCUSSÕES}

\subsection{PERFIL DA AMOSTRA}

A pesquisa considera as diferenças de sexo, idade, renda familiar e escolaridade dos entrevistados. Do total de 30 entrevistados, verificou-se que mais da metade (60\%) eram do sexo feminino, com faixa etária predominante entre 18 a 25 anos (30\%). A maioria dos entrevistados (40\%) possuía $2^{\circ}$ grau completo, sendo $30 \%$ deles possuidores de titulo universitário, configurando desta forma um público de elevado grau de escolaridade. Quanto à renda, a faixa predominante esteve entre 2 à 4 salários mínimos cerca de $57 \%$, e $36 \%$ dos entrevistados possuindo renda de um salário mínimo.

Gráficos com dados do perfil

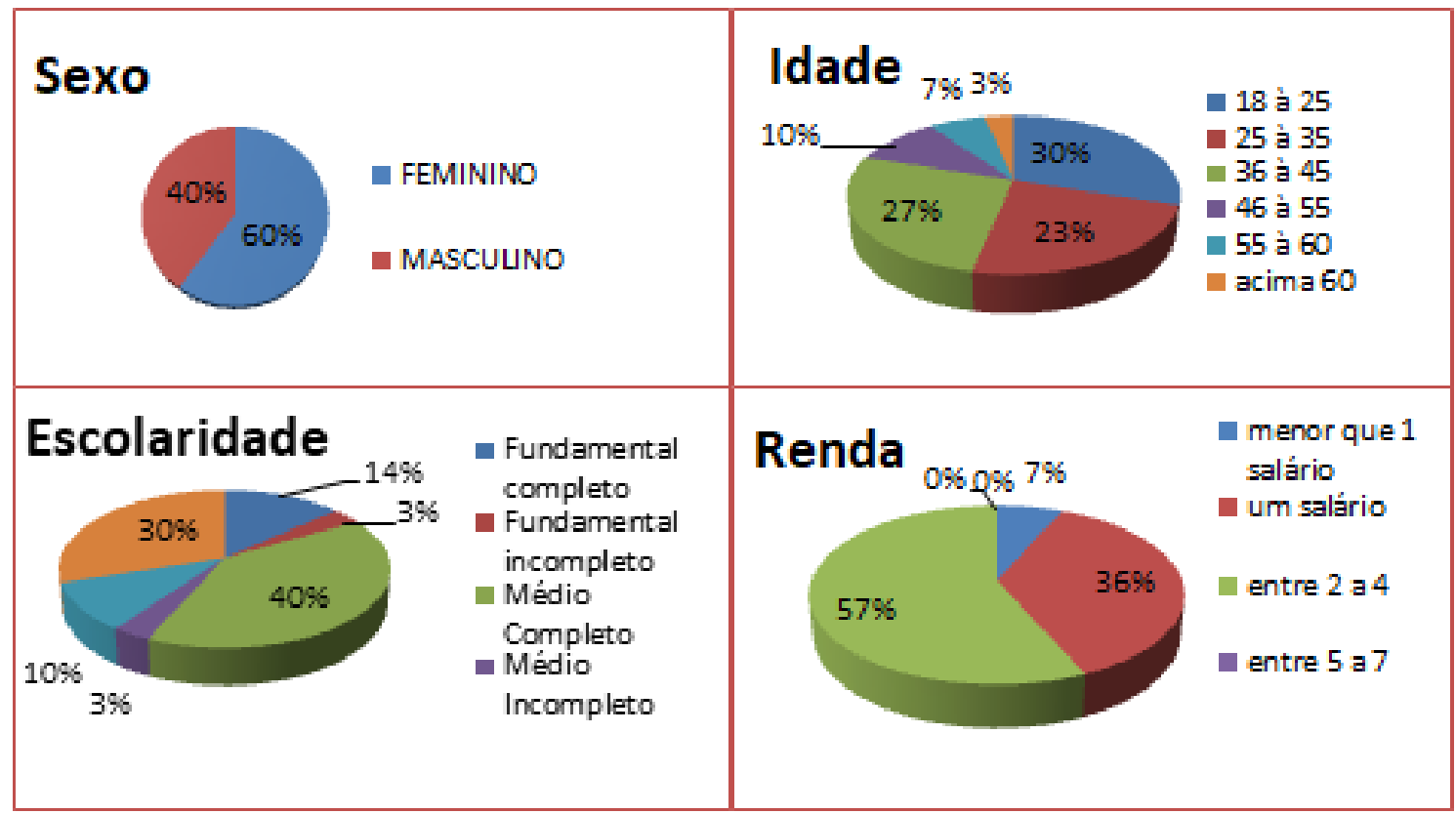




\subsection{CARACTERISTICAS DO CONSUMIDOR}

Nesse trabalho, foram discutidos quais produtos eram mais consumidos e a frequência dentre os dispostos em uma lista de leites e derivados sendo que cada indivíduo poderia escolher apenas dois. Sendo que $28 \%$ respondeu que consomem diariamente o leite integral na forma líquida $20 \%$ leite em pó. E a opção mais consumida dentre os derivados do leite foram o queijo com 18\%, o iogurte com $11 \%$ seguido da manteiga com $8 \%$. Os demais derivados tiveram porcentagens menores. Isso se deu pelo fato de serem alimentos de fácil consumo principalmente no café da manhã que horário em que os entrevistados afirmaram haver o maior consumo.

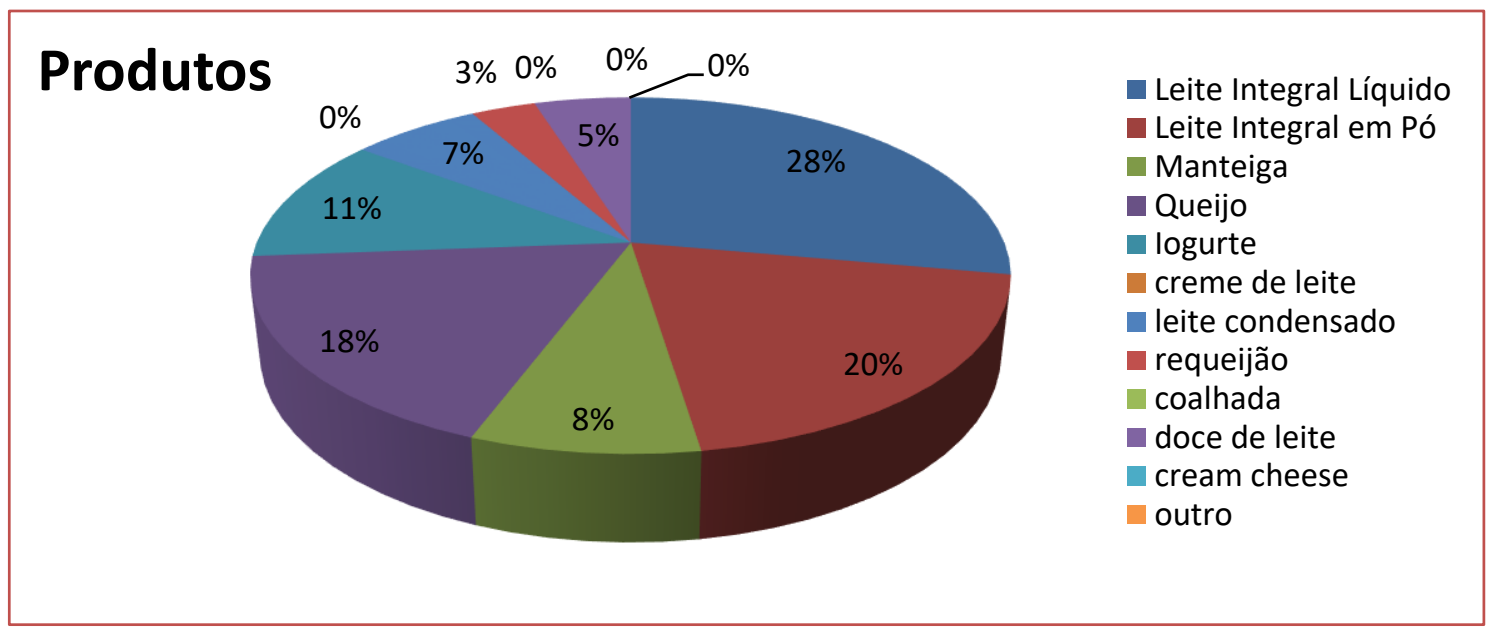

Quando os consumidores foram questionados sobre os motivos que os levaram a consumir tais produtos ou os levava a compra de um produto alimentício principalmente o leite e seus derivados as variáveis, preço acessível teve $48 \%$ da preferencia, sabor 23\%, qualidade 20\%, praticidade 7\% e marca $3 \%$. Segundo Pinheiro et al (2011) o preço é um dos aspectos mais observados por 89\% dos respondentes. Ele preço contribuiu na intenção de compra de todos os potenciais consumidores.

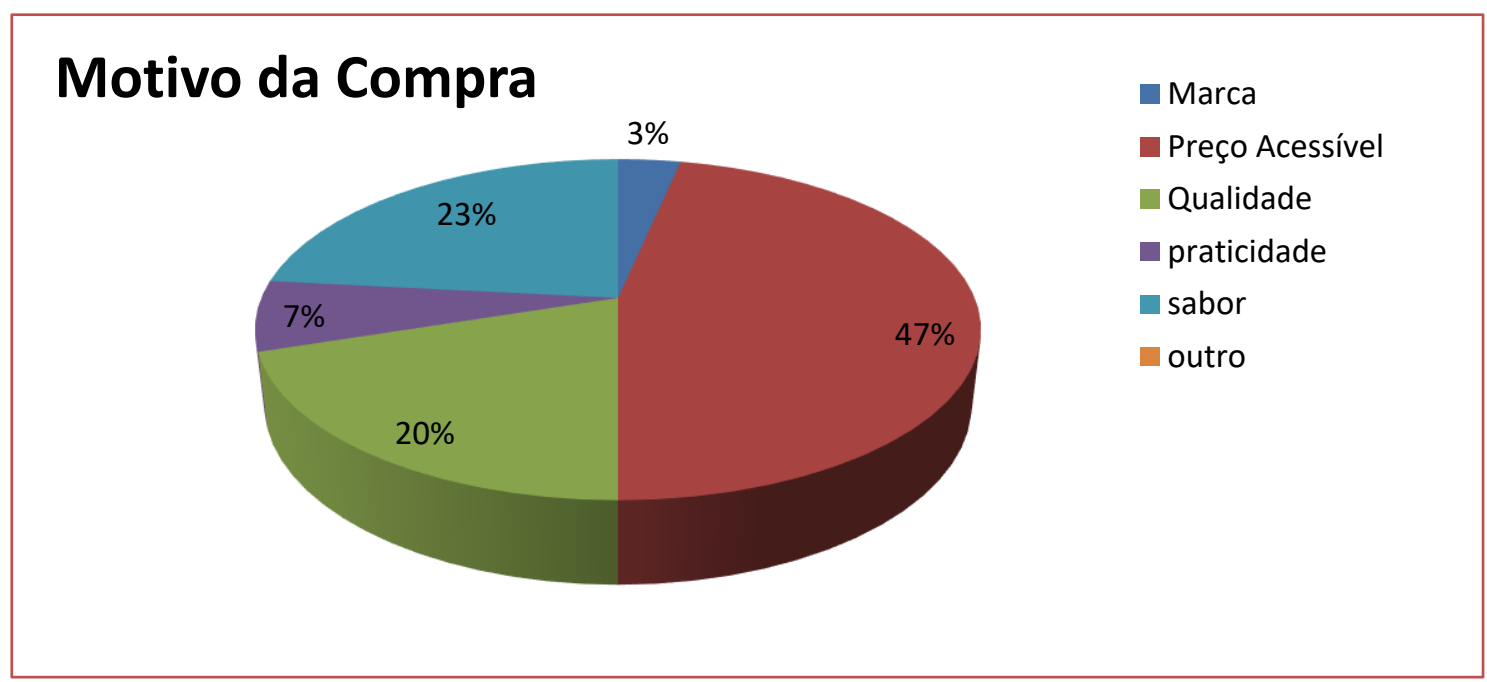

Quanto à legalização dos produtos os questionamentos são de cunho subjetivo desta forma quando indagados se os alimentos que consumiam eram legalizados a maioria $98 \%$ informou que sim e apenas $2 \%$ afirmaram não ter certeza. Já quando indagados se consumiriam produtos se soubessem que não legalizados $100 \%$ afirmou que não. Os consumidores têm direitos assegurados pelo Código de Defesa do Consumidor que determina que fornecedores não podem disponibilizar para venda produtos que tenham 
periculosidade à saúde, sejam nocivos e de baixa segurança para os consumidores, salvo quando o Estado é informado. (BRASIL, 1990)

Quando questionados se acreditam que estes alimentos possam causar doenças 100\% afirmaram que sim. Principalmente quando armazenados de maneira incorreta ou acondicionados em altas temperaturas pode haver a proliferação de bactérias maléficas à saúde dos consumidores. O leite e seus derivados, por sua vez, são produtos altamente perecíveis devido a suas características químicas, físicas e biológicas e facilmente alterados pela ação de microrganismos, o que lhe confere condições de ser considerado um veículo de doenças, caso não seja produzido em um sistema com medidas preventivas de produção (DÜRR, 2004).

Quando arguidos se há preocupação com a qualidade destes tipos de alimentos todos afirmam que sim por diversos motivos, como pelo grande risco de contaminação que estes alimentos implicam, pela ocorrência de infecções alimentares, mas principalmente por conterem microrganismos vivos e em contato com a flora intestinal possivelmente causarem doenças se não obedecerem aos critérios de legislação e vigilância. Segundo Pinheiro et al.(2011) o aumento da exigência de qualidade por parte do consumidor pode ser refletido, sobretudo, no que diz respeito aos aspectos de segurança dos alimentos, dentre os quais, os parâmetros de higiene. Os aspectos de qualidade associados aos nutricionais possivelmente estão relacionados ao aumento do interesse dos consumidores por alimentos saudáveis e de confiança.

Quando interrogados sobre a importância de se consumir produtos de procedência confiável, 100\% garantiram que sim, que é muito importante, pois a vigilância faz constantemente vistorias nas indústrias para garantir se o que está sendo vendido cumpre com os padrões para adquirir selo de qualidade. É indispensável consumir somente produtos legalizados com selo, validade e origem garantida.

O controle de qualidade, de alimentos é exigência legal e um fator essencial para a promoção da saúde pública, reduzindo os índices de toxi-infecções e garantindo maior aceitabilidade e competitividade e dos produtos no mercado. (BOTELHO, 2010 apud. RODRIGUES, 2003)

\section{CONSIDERAÇÕES FINAIS}

O leite e seus derivados são produtos muito consumidos e conhecidos por ampla parcela da população, mas grande parte dela desconhece as diferenças entre os tipos de processamento e quais os critérios para se consumir estes alimentos com qualidade. Assim como os tipos disponíveis no mercado leite existem diversos tipos de iogurte, queijo entre outros que não são avaliados seguindo os critérios corretos para a compra. Sendo que os aspectos de qualidade que deveriam ser considerados no momento da compra são principalmente características organolépticas, qualidade e preço. Mas o que na verdade ocorre é a inversão da ordem onde o preço, características organolépticas e qualidade é que determinam a compra.

A percepção da qualidade por meio da conformidade a requisitos de controle higiênico-sanitário foi bastante citada pelos entrevistados visto que é uma variante importante quando a questão é a compra, porém fica para segundo plano quando a assunto é preço. Visto que a maioria dos consumidores buscam produtos de baixo custo com qualidade e valor razoável.

Acredita-se que o controle de qualidade higiênico-sanitário é de extrema relevância para a competitividade e credibilidade do setor, porém deve ser comunicado de forma mais contundente nos atributos de busca dos produtos lácteos para que os consumidores se conscientizem da importância de um consumo seguro e deve estar acima de qualquer outra variável e deve ser seguida visto que consumir produtos não legalizados e de má qualidade prejudicam tão somente os próprios consumidores.

\section{REFERENCIAS}

[1] Dürr, J. W. (2006). Controle de qualidade e aumento da competitividade da indústria láctea. In C.E. MARTINS (Org.). Tendências e avanços do agronegócio do leite nas Américas: industrialização. Juiz de Fora: Embrapa Gado de Leite.

[2] Farina, M. M. Q., Gutman, G. E., Lavarello, P. J., Nunes, R., \& Reardon, T. (2005). Normas de Leite Privados e Públicos na Argentina e no Brasil. Política Alimentar, 30, 302-315.

[3] Toledo, J. C. de. (2001). Gestão da qualidade na agroindústria. In M.O. BATALHA (Org.) Gestão Agroindustrial. São Paulo: Atlas. 
[4] VIANA, J. G. A. ,RÉVILLION, J.P. P. Qualidade percebida pelo consumidor de produtos lácteos: Modelo Teórico e Evidências Empíricas. Porto Alegre - Rs. (2010). Disponível em:<http://www.sober.org.br/palestra/15/685.pdf> Acesso em: 13/05/2016

[5] Correia, R. T. P., Saber, K. B. ,Araújo, V. M. de .Qualidade do Leite Industrializado: Percepção do Consumidor. Disponível em:< http://www.terraviva.com.br/IICBQL/p049.pdf> Acesso em: 13/05/2016;

[6] LOBATO, V. Tecnologia de fabricação de derivados do leite na propriedade rural. Lavras: UFLA, 2005.

[7] PINHEIRO,F. de A. Perfil de Consumidores em Relação à Qualidade de Alimentos e Hábitos de Compras. Disponível em:< file:///D:/Documentos/Downloads/1231-4762-1-PB\%20(1).pdf> Acesso em: 21/05/2016

[8] RODRIGUES, G. S.; SILVA, F. P.; ÁVIlA, J. S.; VILELA, M. A. P.; FURTADO, M. A. M.; SILVA, P. M. Análise de Produtos Lácteos Realizadas no Laboratório de Análises de Alimentos e Águas da Faculdade de Farmácia e Bioquímica/UFJF em 2003. 


\section{Capítulo 17}

Sorvetes prebióticos de leite de ovelha desnatado: Aspectos tecnológicos, funcionais e nutricionais

\section{Celso Fasura Balthazar}

Hugo L. A. Silva

Alexandre Hargreaves Vieira

Wanessa Pires da Silva

Erick de Almeida Esmerino

Mônica Queiroz de Freitas

Adriano Gomes da Cruz

Resumo: A crescente demanda de consumidores por alimentos mais saudáveis e funcionais levou à introdução de novos ingredientes nas formulações de sorvetes com propriedades nutricionais e fisiológicos, como os prebióticos. A incorporação de ingredientes prebióticos em um sorvete não deve afetar a qualidade do produto. Portanto, seus parâmetros de qualidade, como a incorporação de ar, taxa de derretimento e as características sensoriais, devem ser as mesmas ou melhores, quando comparados a um sorvete convencional. A adição de fibras prebióticas na formulação de sorvete de leite de ovelha desnatado contribui para o aumento da cremosidade do produto com reflexos na sua aceitação sensorial pelos consumidores, além de contribuir para funcionalidade do derivado lácteo, incorporando benefícios a saúde de quem consome este produto. 


\section{INTRODUÇÃO}

O hábito alimentar desempenha papel fundamental na saúde humana. Vários estudos relatam que a alimentação pode causar ou prevenir doenças, por isso os ditos alimentos funcionais chamam a atenção do consumidor. Doenças ligadas à ingestão de gordura como diabetes mellitus, hipertensão, hiperlipidemia e aterosclerose são chamadas de síndromes metabólicas (HIGURASHI et al., 2007). A prevalência da síndrome metabólica aumentou em paralelo com o aumento dos níveis de obesidade e sedentarismo na população (WEISS et al., 2004). A etiologia da obesidade é complexa e envolve, essencialmente, um excesso do consumo de energia sobre o gasto de energia (RUXTON et al., 2010). Estudos indicam que o consumo excessivo de alimentos com alto teor de gordura está associado ao aumento da incidência de obesidade (LA SERRE et al., 2010).

Atualmente, é crescente o número de consumidores que demandam alimentos com propriedades especiais como sabor agradável, baixas calorias ou concentração reduzida de gordura e efeitos benéficos à saúde. Nesse contexto, a indústria desenvolve produtos com melhor aparência e sabor. Assim fibras prebióticas são consideradas abordagem do ponto de vista tecnológico, nutricional e funcional em relação à fabricação de alimentos com redução de açúcar e gordura (AHMED; RASHID, 2017; BALTHAZAR et al., 2017a; VERSPREET et al., 2016).

Os produtos lácteos funcionais apresentam várias exigências nutricionais, bem como benefícios à saúde que são reforçados com adição de certos tipos de fibras solúveis prebióticas. 0 sucesso comercial dos alimentos funcionais perante aos consumidores implica necessariamente, além de segurança e qualidade nutricional, em características sensoriais positivas (CRUZ et al., 2010), que permitem a contínua aquisição e consumo do produto.

O leite e seus derivados são frequentemente incluídos como alimentos importantes para uma saúde e dieta balanceada (PEREIRA, 2014). De acordo com a Food and Agriculture Organization of United Nations, a produção mundial de leite cresce a cada ano, e foi de aproximadamente 800 milhões de toneladas de leite em 2016. Uma fatia pequena, mas também em crescimento é a produção de leite de ovelha, com 10,4 milhões de toneladas (FAOSTAT, 2018), utilizado majoritariamente para elaboração de queijos e iogurtes (PULINA et al., 2018). O leite ovino apresenta elevado valor nutricional em relação às outras espécies domesticas, detendo maiores teores de proteína, lipídios, minerais e vitaminas essenciais (BALTHAZAR et al., 2017a) para a saúde humana.

O mercado de sorvetes no Brasil cresce em torno de $130 \%$ de ao ano, com um consumo nacional de 1,3 bilhões de litros de sorvete. Atualmente, o consumidor não vê mais o sorvete como uma guloseima de verão e sim como um alimento nutritivo que deve ser consumido todo o ano (ITO, 2015). Dentre os derivados lácteos, foi relatada que o sorvete pode ser considerado uma boa matriz veiculadora de ingredientes prebióticos aos consumidores (Balthazar et al., 2017bc), devido a sua composição que inclui proteínas, gordura e lactose, assim como outros nutrientes do leite (CRUZ et al., 2009) e longo período de armazenamento (Balthazar et al., 2018a).

Contudo, a produção de leite de ovelha ainda é muito insípida em relação ao leite bovino e sua utilização é predominantemente para produção de derivados lácteos (ROHENKOHL et al., 2011). 0 desenvolvimento e avaliação dos benefícios funcionais de um sorvete prebiótico utilizando-se como matéria-prima leite de ovelha pode agregar valor a essa matriz, contribuindo para o aumento da sua comercialização.

\section{INGREDIENTES FUNCIONAIS: PREBIÓTICOS}

Os alimentos funcionais apresentam potencial de promover saúde e bem estar por mecanismos não encontrados na nutrição convencional, maximizando as funções fisiológicas de um indivíduo e não a cura de doenças (ROBERFROID, 2007). Os prebióticos são definidos como substratos utilizados seletivamente por microrganismos hospedeiros, conferindo benefícios à saúde (GIBSON et al., 2017).

O termo alimento funcional foi primeiramente introduzido no Japão no início da década de 1980 e foi definido como qualquer alimento ou ingrediente com impacto positivo sobre a saúde, desempenho físico ou estado mental de um indivíduo, além de seu valor nutritivo pela Foods for Specified Health Use (FOSHU) em 1991 (MORAES, 2006). No Brasil, a Agência Nacional de Vigilância Sanitária estabeleceu as quantidades de fibras prebióticas alimentares: lactulose, polidextrose, inulina e FOS devem ser no mínimo $3 \mathrm{~g}$ para $100 \mathrm{~g}$ em alimentos sólidos e 1,5 mL para $100 \mathrm{~mL}$ em alimentos líquidos (BRASIL, 2016).

Segundo Annunziata e Vecchio (2013) os alimentos carreadores de ingredientes funcionais, como prebióticos, têm grande importância para avaliação de alimentos funcionais pelo consumidor. 0 estudo 
confirmou a importância de alegações de saúde perante a aceitação do consumidor com relação ao alimento funcional e sugeriu que os consumidores estejam mais inclinados a aceitar aqueles alimentos com alegação de prevenção à saúde, em vez da alegação de saúde genérico ou psicológica.

Exemplos típicos de compostos prebióticos são os oligossacarídeos não degradados por células de mamíferos, contudo metabolizados por grupos de bactérias (comumente bifidobactérias e lactobacilos) que habitam o intestino daqueles (SANDERS; MARCO, 2010). Assim, esses oligossacarídeos prebióticos geram grandes mudanças específicas nos grupos populacionais de bactérias no ecossistema intestinal e no fluxo direto de carbono a partir de carboidratos que são metabolizados, por exemplo, ácidos orgânicos. 0 acúmulo de ácidos orgânicos no intestino, por sua vez, proporciona a melhora da saúde local e sistêmica (RASTALL; GIBSON, 2015).

Prebióticos podem fornecer uma infinidade de propriedades funcionais quando são incorporados a alimentos (KARIMI et al., 2015). Esses contribuem para mudanças na textura, características sensoriais e prazo de validade dos alimentos devido capacidade de retenção de água livre nos mesmos, capacidade de formação de gel, mimetização da gordura, anti-aderencia, efeitos anti-aglomerativo, texturizante e espessante (RAKHESH et al., 2015). Vários fatores podem afetar o tipo e extensão dos efeitos funcionais, incluindo a origem da fibra vegetal, a relação insolubilidade:solubilidade da fibra, a sinergia fibra-fibra, e as interações com outros componentes alimentares (SOUKOULIS et al., 2009).

De modo geral, os oligossacarídeos prebióticos possuem efeitos sobre patógenos com potencial para reduzir as infecções, incluindo Clostridium difficile (LEWIS et al., 2005), a estimulação da absorção de minerais como o cálcio (WHISNER et al., 2013), redução de diarreia dos viajantes (DRAKOULARAKOU et al., 2010), diminuição de sintomas alérgicos (OSBORN; SINN; 2013), regulação do sistema imune (LOMAX; CALDER; 2009), influências sobre síndrome do cólon Irritável (WHELAN, 2011), e doenças inflamatórias do intestino (LEENEN; DIELEMAN, 2007).

É possível aumentar o número de microrganismos promotores da saúde no trato gastrintestinal, através da introdução de probióticos pela alimentação ou com o consumo de suplemento alimentar prebiótico, o qual irá modificar seletivamente a composição da microbiota, fornecendo ao probiótico vantagem competitiva sobre outras bactérias daquele meio (CRITTENDEN, 1999).

Os produtos lácteos provenientes de pequenos ruminantes são particularmente adequados para serem personalizados para satisfazer as necessidades nutricionais humanas em diferentes condições fisiológicas, em especial, os produtos caprinos e ovinos, que são, na verdade, considerados benéficos para a saúde humana (ALBENZIO et al., 2016). Estratégias tecnológicas para a produção de leite daquelas espécies foram criadas para melhorar os benefícios à saúde através de adjuntos prebióticos (BALTHAZAR et al., 2017a).

\section{LEITE DE OVELHA}

Atualmente o leite ovino é considerado uma iguaria em muitos países, conquistando mercado devido a sua qualidade (BALTHAZAR et al., 2017a), além de suas propriedades físico-químicas, biológicas e alto rendimento. No Brasil a ovinocultura foi iniciada em 1992 com a introdução de ovelhas com aptidão leiteira da raça francesa Lacaune no Rio Grande do Sul. Posteriormente outras raças foram introduzidas, como a italiana Bergamácia e a alemã East Friesian, e a raça nacional Santa Inês recebeu mais atenção nas regiões com clima tropical e subtropical (BALARO et al., 2014). A produção nacional de leite é aproximadamente 33,9 milhões de toneladas (FAOSTAT, 2018), sendo cerca de 0,0019 \% proveniente da matriz ovina, caracterizando uma parcela muito pequena do mercado de leite e derivados (ROHENKOHL et al., 2011).

Os principais constituintes do leite de ovelha são: a água $(82,9 \mathrm{~g} / 100 \mathrm{~g} \pm 1,4)$, a gordura $(5,9 \mathrm{~g} / 100 \mathrm{~g} \pm 0,3)$, as proteínas $(4,7 \mathrm{~g} / 100 \mathrm{~g} \pm 0,5)$, a lactose $(4,8 \mathrm{~g} / 100 \mathrm{~g} \pm 0,4)$; outras substâncias como minerais e vitaminas são encontradas em pequenas quantidades como miligramas ou microgramas por $100 \mathrm{~g}$ de leite (BALTHAZAR et al., 2017a). A composição química de qualquer tipo de leite fresco varia ao longo do tempo, dependendo de fatores como o estágio de lactação, idade do animal, raça, intervalos de ordenha, período do ano e temperatura ambiental, eficiência de lactação, nutrição, hormônios e / ou doença do úbere (TAMIME et al., 2011). A composição lipídica, assim como outros compostos centesimais do leite, apresenta variabilidade devido a fatores genéticos, fisiológicos e ambientais. Este último é de vital importância, pois está associado à variação climática e mudanças sazonais (JAWORSKI; KUNCEWICZ, 2008), interferindo na fisiologia do animal e consequentemente na qualidade e disponibilidade com nutrientes encontrados no leite. 
De acordo com Ranadheera et al. (2018), o leite dos mamíferos contém gordura, ésteres de ácidos graxos e de componentes afins que são solúveis em solventes apolares. Os teores gordurosos relatados no leite das espécies ovina, caprina e bovina, em 100 g, são: 5,3 - 9,1;2,9 - 8,0 e 3,4 - 5,4, respectivamente, e tais frações consistem principalmente em triglicéridos (98\%), fosfolípidos (aproximadamente 1\%) e pequenas quantidades de monoglicerídeos, diglicerídeos, colesterol, ésteres de colesterol, traços de vitaminas lipossolúveis e outras gorduras (TAMIME et al., 1991).

As propriedades únicas do leite de ovelha o diferem dos demais leites, como é o caso da coloração branca intensa e homogênea. Essa característica na espécie ovina está associada à ausência de $\beta$-caroteno, pigmento precursor do retinol (vitamina A), impedindo que o leite tenha coloração amarelada como no caso do leite bovino (NOZIÈRE et al., 2006), caracterizando a produção de diferentes variedades de queijo (TAMIME et al., 2011).

O valor nutritivo do leite ovino é superior quando comparado ao leite caprino e bovino, apresentando maiores teores de proteína, lipídios, minerais e vitaminas essenciais para a saúde humana (BALTHAZAR et al., 2017a). Este leite apresenta três vezes mais caseína em relação aos leites caprino e bovino, sendo suas proteínas consideradas de alto valor biológico e melhor digestibilidade. Outra característica é a conformação estrutural e a quantidade de micelas de caseína e suas subunidades que são, assim como no leite caprino, menores que as do leite bovino, proporcionando menor sensibilização a pessoas alérgicas (MASOODI; SHAFI, 2010). As proteínas do leite de ovelha consistem de caseínas (resistente ao calor) e proteínas do soro (sensível ao calor), logo, tecnologicamente, essas têm propriedades únicas que permitem a fácil conversão do leite em iogurte e queijos, não sendo necessário a fortificação do leite (TAMIME et al., 2011).

O sabor e o aroma do leite de ovelha são suaves e possui uma textura cremosa, devido aos pequenos glóbulos de gordura. Esta peculiaridade no tamanho dos glóbulos gordurosos do leite ovino (BALTHAZAR et al., 2017c) propicia que este seja digerido mais facilmente. 0 leite contém maior quantidade de ácidos graxos saturados de cadeia média e curta, promovendo maior absorção da lactose, o que o torna benéfico aos intolerantes à lactose. Além das prévias características citadas, esse leite contém ácido lático, uma forma conversora da lactose, tornando-a facilmente aceita pelas pessoas intolerantes à lactose (Pereira, 2014).

Apesar de ser um alimento completo para o homem e ser mais nutritivo que o leite bovino, o leite de ovelha é pouco consumido. Uma explicação plausível para seu consumo reduzido é a sazonalidade e a sua pequena produção (BALARO et al., 2014). Logo, este produto é preconizado para elaboração de derivados lácteos, cujo maior valor agregado o torna uma iguaria.

Dentre os derivados lácteos, foi relatado que produtos confeccionados com leite ovino podem ser considerados uma boa matriz veiculadora de ingredientes prebióticos aos consumidores (BALTHAZAR et al., 2015; BALTHAZAR et al., 2017c; BALTHAZAR et al., 2018b). Neste contexto, a percepção dos consumidores de alimentos saudáveis e funcionais conduziu à introdução, na fabricação de sorvetes com ingredientes de propriedades nutricionais e fisiológicos, tais como fibras dietéticas (SOUKOULIS et al., 2009).

\section{SORVETE}

Os sorvetes e sobremesas congeladas são sistemas coloidais complexos que consistem em moléculas de ar, cristais de gelo e glóbulos de gordura parcialmente desestabilizados dispersos em uma fase aquosa contínua dentro de polissacáridos, lactose e outros açúcares, e sais minerais dissolvidos (GOFF; HARTEL, 2013). Por ser elaborado a partir de leite e frutas, principalmente, é considerado um alimento nutritivo representando uma fonte de proteínas, algumas vitaminas, minerais e alguns fitoquímicos (SOUKOULIS et al., 2014; BAHRAM-PARVAR, 2015).

Segundo a Agência Nacional de Vigilância Sanitária (ANVISA), através da Resolução no 266, de 22 de setembro de 2005, os gelados comestíveis ou sorvetes, são produtos congelados obtidos a partir de uma emulsão de gordura e proteínas; ou de uma mistura de água e açúcar(es). Podem ser adicionados de outro(s) ingrediente(s) desde que não descaracterize(m) o produto (BRASIL, 2005).

Segundo a Associação Brasileira das Indústrias de Sorvete (ABIS), no ano de 2018 foram consumidos 1099 milhões de litros de sorvete no Brasil, cada brasileiro consumiu em média 5,27 litros do produto, sendo eles sorvete, picolé e soft. A previsão para 2019 é que o consumo alcance 1107 milhões de litros. (ABIS, 2019). 
Os sabores de sorvete mais consumidos no mundo são: chocolate (21\%); baunilha (13,7\%); morango $(6,3 \%)$ e caramelo (4\%). No Brasil, os sabores preferidos pelos consumidores são: chocolate $(28,8 \%)$; baunilha (10,3\%); morango (9\%); creme (3,8\%); caramelo (3\%); coco (3\%); abacaxi $(2,2 \%)$; passas $(2,2 \%)$; maracujá $(1,9 \%)$ e rum $(1,9 \%)$ (ABIS, 2019).

\subsection{COMPOSIÇÃO DO SORVETE}

A qualidade do sorvete é avaliada através de parâmetros como sabor, textura, consistência e o corpo do produto. A consistência refere-se à dureza ou a maciez, que pode ser afeta pela temperatura ou viscosidade da mistura (CHARLEY; WEAVER, 1998). Entende-se por "corpo" o comportamento do sorvete quando a temperatura é elevada e ele começa a derreter, sendo classificado em viscoso, esponjoso ou agudo e compacto, os cristais de gelo também influenciam na textura, cristais superiores a $55 \mu \mathrm{m}$ produzem uma textura grosseira (GOFF; HARTEL, 2013).

As formulações convencionais de sorvete possuem altas concentrações de sacarose e gordura, as quais estão diretamente relacionadas com a textura, consistência e sabor do produto. Porém com o passar dos anos os consumidores estão se preocupando cada vez mais com a sua saúde, alimentação. Para atender esses consumidores as indústrias vêm desenvolvendo produtos alternativos, com características especiais, os chamados diet e light (GOFF; HARTEL, 2013).

Entre os vários ingredientes utilizados na fabricação do sorvete estão o leite in natura, leite em pó, água, base em pó de vários sabores, gordura vegetal hidrogenada, líquidos concentrados, polpas de frutas, estabilizantes e emulsificantes, a matéria prima precisa utilizada no processamento precisa ser de qualidade, e no preparo da mistura os ingredientes precisam ser cuidadosamente balanceados e perfeitamente misturados para se obter uma combinação satisfatória em termos de cor, aroma, textura, doçura e apresentação (GOFF; HARTEL, 2013).

A gordura normalmente está presente entre 10 e $16 \%$ nos sorvetes, sndo importante para estabilização da espuma, que está diretamente relacionada com a cremosidade e a velocidade de derretimento, além da liberação de moléculas aromáticas hidrossolúveis. A dosagem correta de gordura durante o desenvolvimento de uma formulação é essencial para o equilíbrio da mesma. Os glóbulos de gordura se concentram na superfície das células de ar durante o congelamento, quando se tem o aumento do teor de gordura automaticamente reduz-se os espaços das células de ar, reduzindo assim a formação dos cristais de gelo, porém é importante lembrar que altas taxas de gordura podem restringir o consumo pelo alto valor calórico e alto custo do produto (CRUZ et. al., 2017).

Por se tratar de um componente responsável pela estruturação, a gordura possui um efeito significativo sobre as propriedades térmicas e mecânicas do produto (BALTHAZAR et al., 2017b), além de ser um poderoso agente carreador de sabor, possuir capacidade lubrificante e capaz de provocar sensação de saciedade (SILVA-JUNIOR, 2008).

Os sólidos não gordurosos do sorvete compõem a lactose, caseína, proteínas do soro, minerais, cinzas e vitaminas, sendo componentes importantes, pois auxiliam na melhoria da textura do produto final pela ação das proteínas, auxiliam na obtenção de um produto com melhor palatabilidade e "corpo", aumenta a aeração durante o batimento, contudo é importante atentar para produtos que possam apresentar a sensação de arenosidade quando consumidos, esse efeito se dá pela cristalização da lactose (GOFF; HARTEL, 2013).

As proteínas do leite possuem propriedades emulsificantes, que auxiliam no desenvolvimento da estrutura do sorvete, através do aprisionamento da água, aumento a viscosidade da mistura e reduzindo a formação dos cristais de gelo. Durante o processo de homogeneização provem a emulsificação, pois são fixadas nos glóbulos de gordura, quando ocorre à interação com o agente emulsificante a proteína contribui para aderência parcial e a formação do glóbulo de gordura. Auxiliam na estabilidade da espuma e na aeração, pois são absorvidas na interface do ar, as que não estão presentes na interface, presente na fase aquosa possui uma capacidade significativa de absorção de água, contribuindo assim para melhoria da viscosidade e melhoria do "corpo", como consequência tem-se o aumento do tempo de derretimento e a diminuição da sensação dos cristais de gelo (GOFF; HARTEL, 2013).

As fontes de sólidos não gorduroso são leite concentrado desnatado, leite em pó desnatado, leite condensado adoçado ou não, concentrados de proteína do leite, butter milk condensado ou desidratado. Como fonte de caseína, o caseinato de sódio, soro condensado ou em pó e concentrados ou isolados são 
considerados ingredientes importantes para aumentar o teor de sólidos não gordurosos em sorvete (CRUZ et al., 2017).

A sacarose está presente entre 9 e 12\% nas formulações convencionais de sorvete, com objetivo edulcorante, melhoria da textura e palatabilidade do sorvete, além da liberação de aromas (MALLIATTI, 2013). A sacarose auxilia na redução do ponto de congelamento do sorvete, possibilitando assim que parte da água presente no sorvete fique descongelada mesmo estando à temperatura em torno de $-15^{\circ} \mathrm{C}$, ou seja, diminuindo a dureza e facilitando o manuseio. Além disso, a sacarose possui o efeito na textura do sorvete, pois quanto maior seu peso molecular, maior será a viscosidade da matriz. Quando se tem uma matriz de maior viscosidade à tendência é produzir sorvetes que forneçam a sensação agradável na boca, em contra partida esses sorvetes são mais duros e de difícil manuseio (GOFF; HARTEL, 2013).

Uma alternativa para o uso da sacarose é a substituição que pode ser parcial ou total pelo xarope de glicose, que é um derivado da hidrólise do amido. Quando comparado à sacarose o xarope de amido apresenta algumas vantagens, como suavidade do sorvete por sua maior firmeza, melhoria das características de fusão e acentuação do sabor de frutas. O xarope de glicose possui diferentes concentrações de dextrose, que equivale à quantidade de açúcar redutor calculada como dextrose presente no xarope. Quanto mais intensa a hidrolise do milho, mais doce será o xarope, e assim menor será o ponto de congelamento do sorvete. A hidrolise enzimática e a isomerização do xarope de milho convertem a glicose em frutose, produzindo assim um xarope de milho com alto teor de frutose. Esse xarope reduz o ponto de congelamento do sorvete, tornando o produto mais macio durante o armazenamento (CRUZ et al., 2017).

Os estabilizantes são utilizados para aprimorar textura, reduzir a taxa de derretimento, impede o encolhimento, facilita a incorporação controlada de ar, mascara a sensação de cristais de gelo durante a mastigação, ajuda na produção de uma espuma mais estável, auxilia no bombeamento e enchimento das embalagens (GOFF; HARTEL, 2013). Os estabilizantes são importantes no processo de produção do sorvete, pois possuem resistência significativa as oscilações de temperatura que ocorrem durante o processo de armazenamento e distribuição, que favorece a formação de cristais de gelo e outras deteriorações no sorvete, pois atuam limitando a migração das moléculas de água. Essa capacidade de retenção se da pela ação principalmente do estabilizante, açúcar e proteína (MALLIATTI, 2013).

Por possuir grande capacidade de acumular água os estabilizantes são muito utilizados para suavizar a textura do sorvete e conferir "corpo" acabado, pois aumentam a viscosidade e não afetam o ponto de congelamento (CRUZ et al., 2017). A adição de gomas (goma xantana, goma guar, goma de alfarroba pectina, carragena, carboximetilcelulose, dentre outros) ou hidrocolóides ao sorvete visa retardar o crescimento dos cristais de gelo, pelo aumento da viscosidade na fase liquida que diminui a mobilidade da água e possivelmente aumenta a temperatura de transição vítrea (SOUKOULIS et al., 2014).

A capacidade de absorção de água dos estabilizantes, açúcares e proteínas, reduz a cinética de difusão do sistema, promovendo um mecanismo de recristalização, que consiste em: durante o aquecimento a água que derreteu se mantiver próxima ao cristal que a originou, e quando houver um novo resfriamento e essa água for congelada o cristal formado será de tamanho e forma similar ao original, esse processo é chamado melt-regrow. 0 contrário ocorre quando a água não congelada migra para um cristal maior, e quando houver o resfriamento o cristal formado será de tamanho maior, esse processo é chamado meltdiffuse-grow. Quando é feita a prevenção da formação dos cristais de gelo ocorre o chamado melt grow (SOUKOULIS et al., 2009, 2014).

Quando são utilizados em sorvetes com baixo teor de gordura os estabilizantes aumentam a firmeza do produto, promovem um derretimento mais lento e uniforme, previnem a cristalização da lactose, aumentam a capacidade de aeração, previnem a formação de rachaduras durante o prazo de validade comercial, estabilizam a emulsão, contribuem para "corpo", textura e cremosidade (MILLIATTI, 2013). Se utilizados em excesso os estabilizantes aumentar a viscosidade da calda antes do congelamento, promovendo características indesejáveis de derretimento pela alta viscosidade e o sorvete se tornar gomoso. Os estabilizantes podem ser utilizados de forma combinada, como no caso dos estabilizantes comerciais que em sua maioria são combinações de estabilizantes visando à obtenção de um sorvete com as características desejadas (GOFF; HARTEL, 2013).

Para escolha de um estabilizante é um dos principais critérios visando o efeito sobre a viscosidade causado pelo mesmo, porém a viscosidade não depende somente do emulsificante, e sim de outros componentes como gordura, sólidos totais, sólidos não gordurosos, tipo de adoçante, temperatura e pressão de homogeneização, método de pasteurização, aglutinação da gordura, taxa de resfriamento, período de maturação, dentre outros fatores (CRUZ et al., 2017). 
Os emulsificantes são derivados de gorduras e ácidos graxos os emulsificantes tem a capacidade de modificar a superfície dos sólidos e líquidos, atuam modificando a tensão interfacial entre as duas fases da emulsão para estabiliza-la. 0 uso em sorvete visa conferir ao produto acabado a textura mais macia, aliado ao corpo mais rígido, além de reduzir o tempo de batimento e melhorar a incorporação de ar na mistura (CRUZ et al., 2017). A não utilização do emulsificante na produção do sorvete favorece a separação dos glóbulos de gordura durante a maturação, tornando a gordura livre durante o batimento e levando ao rompimento dos glóbulos (GOFF; HARTEL, 2013). Assim, os emulsificantes mais utilizados pela indústria produtora de sorvete são mono e diacilglicerol, que são produzidos através da hidrólise parcial da gordura vegetal. Em alguns casos também se utiliza triacilglicerol, porém em menor quantidade. 0 excesso de emulsificante na formulação da matriz pode levar a defeitos na textura, "corpo" e derretimento do produto (CRUZ et al., 2017).

É comum realizar a combinação de estabilizantes e emulsificantes, onde é realizada a mistura de um ou mais estabilizante com um ou mais emulsificantes, quando utilizados na forma seca devem ser incorporados junto ao açúcar para evitar a formação de grumos e a perda do efeito do estabilizante, por isso é muito importa a agitação correta durante a incorporação. Durante o processo de escolha do emulsificante deve-se atentar para o que se espera do produto em relação ao seu comportamento no derretimento, exigências dos equipamentos (viscosidade, transferência, envasamento por extrusão ou granel, condições de endurecimento, armazenamento), quantidade de matéria gordura na formulação da matriz, origem da proteína, processo de produção (GOFF; HARTEL, 2013).

\subsection{PROCESSO DE FABRICAÇ̃̃O}

O processo de fabricação do sorvete é realizado a partir da mistura dos ingredientes em uma cuba com agitação para obter a correta distribuição dos componentes da massa, a temperatura deve ser elevada gradativamente até atingir $63^{\circ} \mathrm{C}$, onde são incorporados os corantes, na fase prévia ao congelamento (ORDÓÑEZ, 2005).

Após realizada a mistura, ela é submetida à pasteurização entre 70 e $80^{\circ} \mathrm{C}$ durante 20 a 40 segundos. Seguida da pasteurização e homogeneização para reduzir o tamanho dos glóbulos de gordura (inferior a 2 $\mu \mathrm{m}$ ) e assim tornar a emulsão mais fina e estável, em seguida é realizado o resfriamento a $4^{\circ} \mathrm{C}$ e $\mathrm{o}$ armazenamento entre 2 e 24 horas para que a gordura comece a cristalizar até se iniciar a maturação (ORDÓÑEZ, 2005).

Uma vez maturada, a mistura é acrescida de suco de fruta, corantes, aromas, dentre outros, posteriormente é realizado o congelamento. 0 congelamento ou glaciação é realizado concomitantemente à batedura. 0 congelamento contínuo dispõe de uma camisa dupla dispõe de uma camisa dupla pela qual circula amoníaco ou um liquido refrigerante que diminuiu a temperatura de 4 a $-7^{\circ}{ }^{\circ} \mathrm{C}$, com objetivo de reduzir os cristais de água e atingir uma textura cremosa, durante a batedura duplica-se o volume inicial da mistura pela incorporação de ar, o que era mistura converte-se em sorvete. 0 sorvete, ainda mole e fluido com temperatura em torno de $-7^{\circ} \mathrm{C}$ é dosado por máquinas para encher os diferentes recipientes: potes, copos, taças. Uma vez moldado o sorvete endurece após atingir a temperatura de $-20{ }^{\circ} \mathrm{C}$, ou em túneis de ar forçado a $-40{ }^{\circ} \mathrm{C}$, ou ainda congeladores de placas, o produto deve ser mantido a $-30{ }^{\circ} \mathrm{C}$ no mínimo quatro dias, período em que é realizado o controle de qualidade (ORDÓÑEZ, 2005).

\section{SORVETES PREBIÓTICOS DE LEITE OVINO DESNATADO}

Sorvetes são apreciados ao redor do globo, independentemente da cultura, idade ou nível socioeconômico, a suplementação de oligossacarídeos prebióticos pode agregar valor ao produto, proporcionando apelo funcional (CRUZ et al., 2009; SOUKOULIS et al., 2009; SOUKOULIS et al., 2014).

Enquanto que sorvete de leite de ovelha é uma matriz alimentar interessante apreciado pessoas em todo o mundo (BAHRAM-PARVAR, 2015), os dados relacionados impacto da adição de reposição de gordura pelas fibras prebióticas a reologia, microestrutura e características sensoriais do o produto final deve ser avaliado compulsoriamente.

A substituição do creme de leite por oligossacarídeos dietéticos prebióticos em sorvetes de ovelha contribui para a modificação e melhoria da textura, características sensoriais e prazo de validade dos alimentos, não só devido à capacidade de retenção de água e capacidade de formação de gel, mas também devido aos efeitos miméticos a gordura. 0 tipo de oligossacarídeos e a extensão dos efeitos funcionais estão indubitavelmente relacionados à origem da fibra prebiótica usada, e interações com outros 
componentes alimentares, sendo agregado valor funcional ao novo produto (SOUKOULIS et al., 2009; SOUKOULIS et al., 2014).

\subsection{CARACTERÍSTICAS FÍSICAS DE SORVETES PREBIÓTICOS DE LEITE DE OVELHA DESNATADO}

A incorporação de sorvete ao ar é uma característica física importante, afetando sua qualidade, pois influencia na textura, maciez e estabilidade do sorvete. Quando ar suficiente é misturado em uma mistura durante a etapa de congelamento, podendo duplicar o volume do sorvete produzido (GOFF; HARTEL, 2013).

De acordo com Balthazar et al. (2017b), sorvetes de leite de ovelha contendo gordura de leite de ovelha ou oligossacarídeos prébióticos apresentam um aumento de volume superior a $94 \%$ após a incorporação de ar. Aqueles contendo frutooligossacarídeos, amido resistente ou polidextrose podem auxiliar na incorporação de ar, apresentando volume significativamente superior à versão de sorvete com gordura láctea, devido as características estruturais dos oligossacarídeos como baixo grau de polimerização (GP < 12) (SOUKOULIS et al., 2014; WANG et al., 2014) e baixo peso molecular (ROSE et al., 2010). Segundo Soukoulis et al. (2014), a inulina, a oligofrutose e o amido resistente aumentam substancialmente a o ar incorporado na etapa de congelamento de sorvetes substituídos de gordura láctea. Contudo, este comportamento não foi verificado em sorvetes de leite de ovelha contendo os mesmos ingredientes (BALTHAZAR et al., 2017b).

No estudo sobre a substituição de gordura láctea ovina por fibras prebióticas em sorvete de leite de ovelha, Balthazar et al. (2017b) verificou que a taxa e o tempo de derretimento dos sorvetes foram inversamente proporcionais, sendo que o sorvete contendo gordura láctea demorou 55 minutos para derreter $50 \%$ da quantidade inicial, enquanto os sorvetes contendo oligossacarídeos prebióticos dietéticos levaram 40 minutos para mesma quantidade inicial do produto, demonstrando que a gordura possui papel fundamental no processo de fusão e juntamente com a incorporação de ar torna o derretimento de sorvetes mais lento.

Sorvetes de leite de ovelha contendo inulina, frutooligossacarídeos e polidextrose apresentaram menores taxas de derretimento, devido à capacidade dessas fibras em reduzir a livre circulação de moléculas de água no meio. Assim, sugere-se que os oligossacarídeos dietéticos prebióticos aumentam a interação entre a água e essas fibras, proporcionando maior retenção de água, sendo observado uma correlação negativa entre o tamanho dos cristais de gelo e a água livre, ou seja, os cristais de gelo também contribuem para a mobilidade da água livre (BALTHAZAR et al., 2017b). De acordo com Akın et al. (2007), a adição de inulina em misturas de sorvete aumenta o tempo derretimento, pois a inulina pode atuar como um estabilizador devido sua capacidade de ligação à moléculas de água.

Em relação aos consumidores, o derretimento rápido em sorvetes é indesejável principalmente quando consumidos em cones ou palito. A dispersão de gordura após o congelamento é outra importante característica em sorvetes (GOFF; HARTEL, 2013). Sorvetes de leite de ovelha contendo gordura láctea obviamente apresentam maior taxa de desestabilização da gordura do que os substitutos com fibras prebióticas. Entretanto, o amido resistente adicionado ao sorvete apresenta desestabilização similar a versão tradicional de sorvetes (BALTHAZAR et al., 2017b), provavelmente devido à desestabilização da emulsão quando emulsificantes são adicionados ao produto (GOFF; HARTEL, 2013). Pei e Schmidt (2010) mostraram que quando os glóbulos de gordura são grandes, há uma maior incidência de desestabilização de gordura durante a etapa de congelamento. Assim, sorvetes de leite de ovelha, cujo glóbulo de gordura é menor quando comparado ao de vaca, apresentam forte correlação positiva entre a desestabilização da gordura e o tamanho das partículas de gordura globular (BALTHAZAR et al., 2017b). 0 tamanho médio das partículas de gordura de sorvetes de leite de ovelha é 3,63 $\mu \mathrm{m}$. Misturas de sorvete são consideradas emulsão em gel, ou seja, géis macromoleculares contendo dispersão de partículas de gordura, resultado da adsorção de moléculas de caseínas à gordura pela recém-criada área superficial de membrana (INNOCENTE et al., 2009). Desta forma, Balthazar et al. (2017b) sugerem que para elaboração de sorvetes de leite de ovelha não é necessária a etapa de homogeneização do mesmo.

0 tamanho do cristal de gelo é um fator importante para a qualidade sensorial do sorvete, refletindo sobre a "suavidade", logo devem ser menores que $50 \mu \mathrm{m}$ para evitar a rejeição dos consumidores (GOFF; HARTEL, 2013). Em geral, o tamanho dos cristais de gelo em sorvetes de leite de ovelha varia entre 2,35 $\mu \mathrm{m}^{2}$ (adicionado de amido resistente) e $47,71 \mu \mathrm{m}^{2}$ (fibra de milho solúvel). Este último influencia o fenômeno de recristalização no sorvete, corroborando com uma alta taxa de derretimento. Já a gordura reduzir o tamanho do cristal de gelo, pois dispersa as moléculas de água livre congelável (BALTHAZAR et al., 2017b). Os oligossacarídeos são capazes de reter a água e evitar a recristalização (GOFF, HARTEL, 
2013). Por exemplo, a adição de polidextrose no sorvete pode aumentar a uniformidade dos cristais de gelo, incrementando a cremosidade e a percepção na boca. 0 fruto-oligossacarídeo é caracterizado por uma distribuição de tamanho de cristal de gelo mais uniforme, conferindo uma percepção mais suave, mais cremosa e menos aquosa (ALVAREZ et al., 2005; SOUKOULIS et al., 2009; SOUKOULIS et al., 2014). 0 mesmo ocorre com sorvetes prebióticos de leite de ovelha. 0 diâmetro médio das bolhas de ar em sorvetes de leite de ovelha com gordura láctea ou fibras prebióticas varia entre 3,41 $\mu \mathrm{m}$ e 18,73 $\mu \mathrm{m}$. A fibra de milho solúvel prebiótica e amido resistente promovem a coalescência de bolhas de ar.

A cor é um dos atributos de qualidade mais importantes em alimentos, sendo a aparência do produto um importante fator na escolha pelo consumidor (PATHARE et al., 2013). Além disso, o leite de ovelha é mais branco do que o leite de bovino, devido à ausência de carotenoides (NOZIÈRE et al., 2006). Assim, o índice de brancura é uma característica importante em derivados lácteos ovinos, não sendo diferente para sorvetes sabor natural ou baunilha. Balthazar et al. (2017b) demonstraram que há uma melhora na índice de brancura e liminosidade em sorvetes de leite de ovelha cuja gordura láctea é substituída por oligossacarídeos prebióticos, tornando os sorvetes mais brancos e brilhantes com aparência mais agradável aos mesmos.

A análise calorimétrica em sorvetes permite seu comportamento em relação ao estado físico do produto como ponto de congelamento, temperatura no estado vítreo, incorporação e liberação de calor quando o sorvete muda de estado (sólido/líquido). Os sorvetes de leite de ovelha possuem comportamento o endotérmico quando a temperatura se aproxima a $0{ }^{\circ} \mathrm{C}$, sendo assim atribuído ao processo de derretimento do gelo. 0 ponto de congelamento é um parâmetro crítico na produção de sorvetes, pois influencia o tamanho médio inicial dos cristais de gelo formados e sua instabilidade termodinâmica, que leva ao seu crescimento gradual (HARTEL, 2001). 0 comportamento da água não congelável não muda significativamente em sorvetes com gordura láctea ou substituída por fibras prebióticas, sendo a concentração de água não congelável em sorvetes de leite de ovelha entre $11 \%$ e 35 \% dependendo da fibra prebiótica utilizada (BALTHAZAR et al., 2017b).

\subsection{CARACTERÍSTICAS NUTRICIONAIS E FUNCIONAIS DE SORVETES PREBIÓTICOS DE LEITE DE OVELHA DESNATADO}

Devido o leite de ovelha ser uma matriz alimenta altamente proteica (BALTHAZAR et al., 2017a), o conteúdo proteico em sorvetes é semelhante aos valores de proteína em sorvetes de leite de vaca adicionados com outras fontes proteicas como ovo ou leite em pó (GOFF; HARTEL, 2013). 0 teor proteico proveniente da proteína láctea tem um grande impacto no valor nutricional e tecnológico nos derivados (Dario et al., 2008). Assim, não é necessária adição de outras fontes proteicas a sorvetes de leite de ovelha com objetivo de melhorar seu valor nutricional. Outra característica intrínseca importante das proteínas do leite de ovelha é a sua conformação estrutural e quantidade micelas e subtipos, que são menores do que o leite de vaca e semelhante ao leite de cabra, promovendo menor sensibilização alérgica quando em comparação com o leite de vaca (BALTHAZAR et al., 2017a).

Já a substituição de gordura láctea por diferentes tipos de ingredientes prebióticos em sorvete de leite de ovelha resulta em menor valor calórico (de 175,75 para aproximadamente $99 \mathrm{kcal} / 100 \mathrm{~g}$, BALTHAZAR et al. 2017c). Sorvetes são geralmente classificados pelo conteúdo de gordura (GOFF; HARTEL, 2013). A substituição de gordura por fibras prebióticas reivindica um apelo funcional para o sorvete, uma vez que os prebióticos são classificados como componentes alimentares não digeríveis que fornecem saúde ao hospedeiro por modular a microbiota intestinal (FAO, 2007). Além disso, os prebióticos são bem exemplos sucedidos de classes funcionais de alimentos que promovem a saúde e bem-estar para os indivíduos (YASMIN et al., 2015).

\subsection{CARACTERÍSTICAS REOLÓGICAS DE SORVETES PREBIÓTICOS DE LEITE DE OVELHA DESNATADO}

Sorvetes de leite de ovelha com substitutos da gordura como frutooligossacarídeos de longo e baixo grau de polimerização são os que mais se assimilam a gordura láctea, pois os mesmos apresentam tensão residual, representando um comportmento viscoelástico que corresponde ao valor limite em que quando a tensão aplicada decresce, comportamento típico de um alimento sólido no analisado. A tensão residual normalmente está correlacionada ao corpo, textura e colherabilidade em sorvetes (JAVIDI et al., 2016). 
Segundo Innocente et al. (2009) a adição de diversas fibras aplicadas proporciona uma diminuição na ordem de 100 vezes da consistencia, exceto para sorvetes adicionados de inulina ou frutooligossacarídeos. Este fato indica indica que tanto a inulina quanto o fruto-oligossacarídeo promovem um efeito protetor frente a perda de consistência devido a redução do teor de gordura propiciam um aumento no índice de consistência.

Em geral, a redução do teor de gordura permite a diminuição da interação intermolecular entre as moléculas de proteína e a água, aumentando a mobilidade da matriz proteica tornando a amostra menos consistente. Assim, sorvetes de leite e ovelha desnatado contendo fibras apresentam comportamento pseudoplástico, em que a viscosidade aparente diminui com o aumento da taxa de deformação aplicada. Esse fato pode estar relacionado às macromoléculas, como proteína e gordura, que tendem a se orientar na direção do movimento do fluido diminuindo, portanto, a resistência ao escoamento com o aumento da taxa de deformação (DERTLI et al., 2016).

Os sorvetes de leite de ovelha contendo fibras dietéticas em substituição a gordura tornam o produto mais saudável e com valor funcional, sendo as amostras contendo as fibras inulina e fruto-oligossacarídeo aquelas cujos resultados reológicos mais se aproximaram aos valores do sorvete de leite de ovelha contendo gordura, indicando assim o potencial tecnológico destas fibras como substitutos da gordura em sorvetes (BALTHAZAR et al., 2017c).

\subsection{CARACTERÍSTICAS SENSORIAIS DE SORVETES PREBIÓTICOS DE LEITE DE OVELHA DESNATADO}

Balthazar et al. (2017c) submeteram sorvetes de leite de ovelha desnatado adicionados de fibras prebióticas ao teste sensorial Pivot Profile ${ }^{\circledR}$, sendo o sorvete de leite de ovelha contendo gordura láctea de leite de ovelha a amostra a ser comparada com as amostras do produto desnatado (pivô). Assim, a formulação de sorvete contendo amido resistente recebeu mais citações pelo sabor e firmeza do milho, enquanto o sorvete contendo inulina e fruto-oligossacarídeo recebeu mais citações por cremosidade e brilho, respectivamente. Finalmente, sorvete contendo fruto-oligossacarídeo de cadeia curta, fibra de milho solúvel e polidextrose receberam mais citações de sabor de baunilha, aroma de baunilha e sabor de leite, enquanto o sorvete contendo galacto-oligossacarídeo recebeu mais citações para gosto amargo e derretimento.

A maioria das fibras prebióticas utilizadas naquele estudo melhoraram o poder edulcorante do sorvete de leite de ovelha desnatado, no que tange a percepção dos consumidores (BALTHAZAR et al., 2017c). A cremosidade da amostra contendo inulina foi maior quando comparado ao pivô, e pode ser devido à maior retenção de água capacidade dessa fibra (KARIMI et al., 2015). De fato, cremosidade é um atributo sensorial complexo diretamente relacionado a aceitabilidade de sobremesas lácteas semi sólidas, incluindo sorvetes, e o atributo cremoso é usado pelos consumidores para descrever várias características, muitas vezes sem distinções claras entre eles (FONSECA et al., 2016).

\section{CONCLUSÃO}

A substituição da gordura do leite de ovelha por oligossacarídeos prebióticos em formulações de sorvetes de leite de ovelha apresenta-se uma maneira eficaz de melhorar os aspectos nutricionais e promover a funcionalidade, influenciando as propriedades térmicas dos sorvetes. Logo este derivado lácteo apresenta baixo valor calórico e funcionalidade fornecida pelos prebióticos. As fibras inulina e fruto-oligossacarídeo substituem adequadamente à gordura do creme de leite de ovelha, pois resultam em produtos tecnologicamente, reologicamente e sensorialmente semelhantes àqueles contendo creme de leite em sua formulação.

Assim, os oligossacarídeos adicionados a sorvetes de leite de ovelha desnatado apresentaram quantidades adequadas de fibra, sendo esses considerados prebióticos de acordo com a legislação nacional e internacional. Sensorialmente, sorvetes prebióticos de leite de ovelha desnatado demonstram boa aceitação pelo consumidor, fator favorável à produção e comercialização dos novos produtos lácteos a base de leite de ovelha. 


\section{REFERENCIAS}

[1] Abis. Associação Brasileira das indústrias de Sorvete. Estatística da produção e consumo de sorvete no Brasil. São Paulo, 2018. Disponível em: <http://www.abis.com.br/estatistica_producaoeconsumodesorvetesnobrasil.html>. Acesso em: 31 maio 2019.

[2] Ahmed, W.; Rashid, S. Functional and therapeutic potential of inulin: a comprehensive review. Critical Reviews in Food Science and Nutrition. v.11, p.1-13, 2017.

[3] Akin, M. B.; Akin, M. S.; Kirmaci, Z. Effects of inulin and sugar levels on the viability of yogurt and probiotic bacteria and the physical and sensory characteristics in probiotic ice-cream. Food Chemistry. v.104, p.93-99, 2007.

[4] Albenzio, M.; Santillo, A.; Avondo, M.; Nudda, A.; Chessa, S.; Pirisi, A.; Banni S. Nutritional properties of small ruminant food products and their role on human health. Small Ruminant Research. v.135, p.3-12, 2016.

[5] Alvarez, V. B.; Wolters, C. L.; Vodovotz, Y.; JI, T. Physical properties of ice cream containing milk protein concentrates. Journal of Dairy Science. v.88, p.862-871, 2005.

[6] Annunziata, A.; Vecchio, R. Consumer perception of functional foods: A conjoint analysis with probiotics. Food Quality and Preference. v.28, p.348-355, 2013.

[7] Bahram-Parvar, M. A review of modern instrumental techniques for measurements of ice cream characteristics. Food Chemistry. v.188, p.625-631, 2015.

[8] Balaro, M. F.; Fonseca, J. F.; Oba, E.; Cruz, C. E.; Brandão, F. Z. Is the Santa Inês sheep a typical non-seasonal breeder in the Brazilian Southeast? Tropical Animal Health and Production. v.46, p.1533-1537, 2014

[9] Balthazar, C. F.; Gaze, L. V.; Silva, H. L. A.; Pereira, C. S.; Franco, R. M.; Conte-Junior, C. A.; Freitas, M. Q.; silva A. C. O. Sensory evaluation of ovine milk yoghurt with inulin addition. International Journal of Dairy Technology. v.68, p.281-290, 2015.

[10] Balthazar, C. F.; Pimentel, T. C.; Ferrão, L. L.; Almada, C. N.; Santillo, A.; Albenzio, M.; Mollakhalili, N.; Mortazavian, A. M.; Nascimento, J. S.; Silva, M. C.; Freitas, M. Q.; Sant'ana, A. S.; Granato, D.; CRUZ, A. G. Sheep milk: physicochemical characteristics and relevance for functional food development. Comprehensive Reviews in Food Science and Food Safety. v.16, p.247-262, 2017a.

[11] Balthazar, C. F.; Silva, H. L. A.; Vieira, A. H.; Neto, R. P. C.; Cappato, L. P.; Coimbra, P. T; Moraes, J.; Andrade, M. M.; Calado V. M. A.; Granato, D.; Freitas, M. Q.; Tavares, M. I. B.; Raices, R. L.; Silva, M.C.; Cruz, A. G. Assessing the effects of different prebiotic dietary oligosaccharides in sheep milk ice cream. Food Research International. v.91, p.38-46, 2017b.

[12] Balthazar, C. F.; Silva, H. L. A.; Cavalcanti, R. N.; Esmerino, E. A.; Cappato, L. P.; Abud, Y. K. D.; Moraes, J.; Andrade, M. M.; Freitas, M. Q.; Sant'anna, C.; Raices, R. S. L.; Silva, M. C.; Cruz, A. G. Prebiotics addition in sheep milk ice cream: a compositional, rheological, microstructural and sensory study. Journal of Functional Foods . v.35, p.564-573, 2017 c.

[13] Balthazar, C. F.; Silva, H. L. A.; Esmerino, E. A.; Ramon, S. R.; Moraes, J.; Carmo, M. A. V.; Azevedo, L.; Camps, I.; Abud, Y. K. D.; Sant'anna, C; Franco, R. M.; Freitas, M. Q.; Silva, M. C.; Raices, R. S. L .; Escher, G. B.; Granato, D.; Ranadheera, C. S.; Nazarro, F.; Cruz, A. G. The addition of inulin and Lactobacillus casei 01 in sheep milk ice cream. Food Chemistry. v.246, p.464-472, 2018a.

[14] Balthazar, C. F.; Santillo, A.; Figliola, L.; Silva, H. L. A.; Esmerino, E. A.; Freitas, M. Q.; Cruz, A. G.; Albenzio, M. Sensory evaluation of a novel prebiotic sheep milk strawberry beverage. LWT - Food Science \& Technology. v.98, 9498, 2018b.

[15] Brasil. Alimentos com alegações de propriedades funcionais e ou de saúde. Lista de alegações de propriedade funcional aprovadas. Diário Oficial [da] República Federativa do Brasil, Poder Executivo, Brasília, DF. 2016. Disponível em http://brasil.gov.br>

[16] Brasil. Resolução no 266, de 22 de setembro de 2005. Regulamento técnico para gelados comestíveis e preparados para gelados comestíveis. Diário Oficial [da] República Federativa do Brasil, Brasília, 2005. Disponível em: <http://www. http://portal.anvisa.gov.br>. Acesso em: 19 nov. 2018.

[17] Charley, H.; Weaver, C. Foods: a scientific approach. 3 ed. New Jersey: Prentice-Hall, 1998, p. 243-268.

[18] Crittenden, R.G. Prebiotics. In: Tannock, G.W. Probiotics: a critical review. Norfolk, Usa: Horizon Scientific Press. p.141-156. 1999.

[19] Cruz, A. G.; Antunes, A. E. C.; Sousa, A. L. O. P.; Faria, J. A. F.; Saad, S. M. I. Ice cream as a probiotic food carrier. Food Research International. v.42, p.1233-1239, 2009.

[20] Cruz, A. G.; Cadena, R. S.; Walter, E. H. M.; Mortazavian, A. M.; Granato, D.; Faria, J. A. F.; Bolini, H. M. A. Sensory analysis: Relevance for prebiotic, probiotic, and synbiotic product development. Comprehensive Reviews in Food Science and Food Safety. v.9, p.358-373, 2010. 
[21] Cruz, A. G.; Zacarchenco, P. B.; Oliveira, C. A. F.; Corassin, C. H. Processamento de produtos lácteos: queijos, leites fermentados, bebidas lácteas, sorvete, manteiga, creme de leite, doce de leite, soro em pó, e lácteos funcionais. Rio de Janeiro: Elsevier, 2017, 360p.

[22] Dertli, E.; Toker, O. S., Durak, M. Z., Mustafa, T. Y.; Tatlisu, N. B.; Sagdic, O.; Cankurt, H. Development of a fermented ice-cream as influenced by in situexopolysaccharide production: Rheological, molecular,microstructural and sensory characterization. Carbohydrate Polymers, v.136, p.427-440, 2016.

[23] Drakoularakou, A.; Tzortzis, G.; Rastall, R. A.; Gibson, G. R. A doubleblind, placebo-controlled, randomized human study assessing the capacity of a novel galacto-oligosaccharide mixture in reducing travellers' diarrhoea. European Journal of Clinical Nutrition. v.64, p.146-152, 2010.

[24] Fao. Technical meeting on prebiotics. Rome, Italy. 2007.

[25] Faostat. Statistics database. Food and Agriculture Organization of United Nations, Rome, $2018 .<$ http://www.fao.org/faostat/en/\#home >Acessado em Março de 2019.

[26] Fonseca, F. G. A.; Esmerino, E. A.; Tavares Filho, E. R.; Ferraz, J. P.; Cruz, A. G.; Bolini, H. M. A. Novel and successful free comments method for sensory characterization of chocolate ice cream: A comparative study between pivot profile and comment analysis. Journal of Dairy Science. v.99, p.3408-3420, 2016.

[27] Gibson, G. R.; Hutkins, R.; Sanders, M. E.; Prescott, S. L.; Reimer, R. A.; Salminen, S. J.; Scott, K.; Stanton, C.; Swanson, K. S.; Cani, P. D.; Verbeke, K.; Reid, G. The International Scientific Association for Probiotics and Prebiotics (Isapp) consensus statement on the definition and scope of prebiotics. Nature Reviews / Gastroenterology \& Hepatology, v.14, p.491-502, 2017.

[28] Goff, H. D.; Hartel, R.W. Ice cream. New York: Springer 7th ed. Oxford, UK/Iowa/USA: Blackwell Publishing Professional. 462 p. 2013.

[29] Hartel, R. W. Crystallization in foods (1st ed.). Gaithersburg, Maryland/USA: Aspen Publishers Inc. 2001.

[30] Higurashi, S.; Kunieda, Y.; Matsuyama, H.; Kawakami, H. Effect of cheese consumption on the accumulation of abdominal adipose and decrease in serum adiponectin levels in rats fed a calorie dense diet. International Dairy Journal. v.17, p.1224-1231, 2007.

[31] Ito, T. Consumo: avalanche premium. Industria de sorvetes aposta na qualidade para lancer novidades e expander o Mercado consumidor. Leite \& Derivados. v.156, p.40-43, 2015.

[32] Javidi, F.; Razavi. S. M.A.; Behrouzian, A. F. A. The influence of basil seed gum, guar gum and their blend on the rheological, physical and sensory properties of low fat ice cream. Food Hydrocolloids, v.52, p.625-633, 2016.

[33] Jaworski, J.; Kuncewicz, A. Właściwości fizykochemiczne mleka. In: Ziajka, S. Mleczarstwo. Olsztyn,Polska: Wyd. UWM, 2008. vol. 1, p.53. (polonês).

[34] Karimi, R.; Azizib, M.H.; Ghasemlouc, M.; Vaziri, M. Application of inulin in cheese as prebiotic, fat replacer and texturizer: A review. Carbohydrate Polymers. v.119, p.85-100, 2015.

[35] La Serre, C. B.; Ellis, C. L.; Lee, J.; Hartman, A. L.; Rutledge, J. C.; Raybould, H. E. Propensity to high-fat dietinduced obesity in rats is associated with changes in the gut microbiota and gut inflammation. American Journal of Physiology. v.299, p.G440-G448, 2010.

[36] Leenen, C. H.; Dieleman, L. C. Inulin and oligofructose in chronic inflammatory bowel disease. Journal of Nutrition. v.137, p.2572S-2575S, 2007.

[37] Lewis, S.; Burmeister, S.; Brazier, J. Effect of the prebiotic oligofructose on relapse of Clostridium difficileassociated diarrhea: a randomized, controlled study. Clinical Gastroenterology and Hepatology., v.3,p.442-448, 2005.

[38] Lomax, A. R.; Calder, P. C. Prebiotics, immune function, infection and inflammation: a review of the evidence. British Journal of Nutrition. v.101, p.633-658, 2009.

[39] Masoodi, T. A.; Shafi, G. Analysis of casein alpha S1 \& S2 proteins from different mammalian species. Bioinformation. v.4, p.430-435, 2010.

[40] Milliatti, M. C. Estudo reológico de formulações para sorvetes produzidos com diferentes estabilizantes. São Paulo, 2013. 108f. Dissertação (Mestrado em Tecnologia de Alimentos) - Departamento de Tecnologia BioquímicoFarmacêutica, Universidade de São Paulo, São Paulo, 2013.

[41] Moraes, F. Alimentos funcionais e nutracêuticos: definições, legislação e benefícios à Saúde. Revista Eletrônica de Farmácia. v. 3, n. 2, p. 109-122, 2006.

[42] Nozière, P.; Graulet, B.; Lucas, A.; Martin, B.; Grolier, P.; Doreau, M. Carotenoids for ruminants: from forages to dairy products. Animal Feed Science and Technology. v.131, p.418-50, 2006.

[43] Ordóñez, J. A. Tecnologia de Alimentos: componentes dos alimentos e processados. vol. 1. Porto Alegre: Artmed, 2005, 294p. 
[44] Osborn, D. A.; Sinn, J.K. Prebiotics in infants for prevention of allergy. Cochrane Database System Review. v.3, p.64-74, 2013.

[45] Pathare, P. B.; Opara, U. L.; AL-Said, F. A. Colour measurement and analysis in fresh and processed foods: A review. Food Bioprocess Technology. v.6, p.36-60, 2013.

[46] Pei, X. E. Z. J.; Schmidt, K.A. Ice Cream: Foam formation and stabilization - A Review. Food Reviews International. v.26, p.122-137, 2010.

[47] Pereira, P. C. Milk nutritional composition and its role in human health. Nutrition. v.30, p.619-627, 2014.

[48] Pulina, G.; Milán, M. J.; Lavín, M. P.; Theodoridis, A.; Morin, E.; Capote, J.; Thomas, D. L.; Francesconi, A. H. D.; Caja, G. Invited review: Current production trends, farm structures, and economics of the dairy sheep and goat sectors. Journal of Dairy Science. v. 101, p.1-15. 2018.

[49] Rakhesh, N.; Fellows, C. M.; Sissons, M. Evaluation of the technological and sensory properties of durum wheat spaghetti enriched with different dietary fibres. Journal of the Science of Food and Agriculture. v.95, p.2-11, 2015.

[50] Ranadheera, C.S.; Naumovski, N.; Ajlouni, S. Non-bovine milk products as emerging probiotic carriers: recent developments and innovations, Current Opinion in Food Science. In Press, 2018, https://doi.org/10.1016/j.cofs.2018.02.010

[51] Rastall, R. A.; Gibson, G. R. Recent developments in prebiotics to selectively impact beneficial microbes and promote intestinal health. Current Opinion in Biotechnology. v.32, p.42-46, 2015.

[52] Roberfroid, M. Prebiotics: the concept revisited. Journal of Nutrition. v.137, p.830S-837S, 2007.

[53] Rohenkohl, J. E.; Corrêa, G. F.; Azambuja, D. F.; Ferreira, F. R. O agronegócio de leite de ovinos e caprinos. Indicadores Econômicos Fee. v. 39, n. 2, p. 97-114, 2011.

[54] Rose, D. J.; Inglett, G. E.; Liu, S. X. Utilisation of corn (Zea mays) bran and corn fiber in the production of food components. Journal of the Science of Food and Agriculture. v.90, p.915-924, 2010.

[55] Ruxton, C. H. S.; Gardner, E. J; Mcnulty H. M. Is sugar consumption detrimental to health? A review of the evidence: 1995-2006. Critical Reviews in Food Science and Nutrition. v.10, p.1-19, 2010.

[56] Sanders, M. E.; Marco, M L. Food formats for effective delivery of probiotics. Annual Review of Food Science and Technology. v.1, p.65-85, 2010.

[57] Silva-Junior, E. Formulações especiais para sorvete. São Paulo, 2008. Dissertação (Mestrado em Tecnologia de Alimentos) - Departamento de Tecnologia Bioquímico-Farmacêutica, Universidade de São Paulo, São Paulo, 2008.

[58] Soukoulis, C.; Fisk, I. D.; Bohn, T. Ice cream as a vehicle for incorporating healthpromoting ingredients: Conceptualization and overview of quality and storage stability. Comprehensive Reviews in Food Science and Food Safety. v.13, p.627-655, 2014.

[59] Soukoulis, C.; Lebesi, D.; Tzia, C. Enrichment of ice cream with dietary fibre: Effects on rheological properties, ice crystallisation and glass transition phenomena. Food Chemistry. v.115, p.665-671, 2009.

[60] Tamime, A. Y.; Wszolek, M.; Bozanic, R.; Özer, B. Popular ovine and caprine Fermented milks. Small Ruminant Research. v.101, p.2-16, 2011.

[61] Verspreet, J.; Damen, B.; Broekaert, W. F.; Verbeke, K.; Delcour, J.; Courtin, C. M. A critical look at prebiotics within the dietary fiber concept. Annual Review of Food Science and Technology. v.7, p.167-190, 2016.

[62] Wang, H.; Shi, Y.; le, G. Rapid microwave-assisted synthesis of polydextrose and identification of structure and function. Carbohydrate Polymers. v.113, p.225-230, 2014.

[63] Weiss, R.; Dziura, J.; Burgert, T. S.; Tamborlane, W. V.; Taksali, S. E.; Yeckel, C.W.; Allen, K.; Lopes, M.; Savoye, M.; Morrison, J.; Sherwin, R. S.; Caprio, S. Obesity and the metabolic syndrome in children and adolescents. New England Journal of Medicine. v.350, p.2362-2374, 2004.

[64] Whelan, K. Probiotics and prebiotics in the management of irritable bowel syndrome: a review of recent clinical trials and systematic reviews. Current Opinion in Clinical Nutrition \& Metabolic Care. v.14, p.581-587, 2011.

[65] Whisner, C. M.; Martin, B. R.; Schoterman, M. H.; Nakatsu, C. H.; Mccabe, L. D.; Mccabe, G. P.; Wastney, M. E.; van Den Heuvel, E. G.; Weaver, C. M. Galactooligosaccharides increase calcium absorption and gut bifidobacteria in young girls: a doubleblind cross-over trial. British Journal of Nutrition. v.110, p.1-12, 2013.

[66] Yasmin, A.; But, M. S.; Afzaal, M.; Van Baak, M.; Nadeem, M. T.; Shahid, M. Z. Prebiotics, gut microbiota and metabolic risks: Unveiling the relationship. Journal of Functional Foods. v.17, p.189-201, 2015. 


\section{Capítulo 18}

Readequação do processo produtivo e da distribuição de salgados quentes em lanchonete de uma rede de supermercados da Grande Florianópolis/SC

Lucas Vaz da Rosa

Laura Gabriela Magnabosco

Roberta Juliano Ramos

Isaura Hammerschmitt Clemente

Resumo: A alimentação de qualidade é uma das características essenciais da vida humana, onde todo o processo de produção, manuseio, transporte e armazenamento dos alimentos tem grande importância e necessita de cuidados relacionados com a segurança alimentar. Toda unidade que está relacionada a nutrir e alimentar a população deve seguir determinados padrões de qualidade para manter níveis aceitáveis de contaminantes de origem biológica, química ou física e para não causarem danos à saúde do consumidor. A temperatura ganha destaque principal entre os fatores de prevenção e manutenção de qualidade, pois mantendo um controle dentro dos níveis adequados, o alimento permanece fora do risco de contaminação microbiológica. Este estudo objetivou analisar os procedimentos de quatro salgados em um supermercado de Florianópolis, onde foi verificado as temperaturas a partir do momento final da cocção até a venda para o consumidor. Após verificar a exposição dos alimentos em temperaturas inadequadas neste período, foram feitas alterações nos horários de cozimento e de acionamento dos equipamentos, para que os salgados não ficassem expostos à temperatura ambiente até o momento da disposição na estufa. Posteriormente a adequação, os salgados permaneceram na temperatura ideal em todo o processo. 0 controle do tempo e da temperatura são um dos meios mais eficazes para combater microrganismos e minimizar os riscos de contaminação pela proliferação microbiológica patogênica. Levando-se em conta esses fatores, o presente estudo teve como objetivos, contribuir para melhoria do serviço de padaria na UAN, verificar as temperaturas de distribuição dos salgados e equipamentos durante um determinado período de tempo e avaliar os resultados de acordo com a legislação vigente (Resolução $\left.\mathrm{RDC} \mathrm{n}^{\circ} 216\right)$.

Palavras-Chave: segurança alimentar, temperatura de alimentos, contaminação biológica 


\section{INTRODUÇÃO}

Devido a necessidade de comer fora de casa em conjunto com a mudança de hábitos, uma grande parte da população brasileira opta por alimentar-se com alimentos prontos e de fácil acesso como salgados, doces e bebidas industrializadas. Para realizar esse serviço dispomos de lanchonetes, bares, restaurantes, e as Unidades de alimentação e Nutrição (UAN) que se refere a qualquer unidade que esteja relacionada com alimentar e nutrir a população (VENTIMIGLIA; BASSO 2008). Sendo assim, é imprescindível que todo e qualquer alimento seja de qualidade e seguro ao consumo.

Visando a prevenção de contaminações e saúde dos consumidores, pois estes serviços atendem à um grande número de pessoas, é indispensável dentro do âmbito segurança alimentar, o monitoramento de temperatura e transporte destes alimentos nestas unidades, desde os momentos iniciais da preparação, até o consumidor final (TRINDADE et al. 2009). De acordo com SILVA, 2006, o termo alimento seguro significa uma condição de alimento apto para consumo, ou seja, são produtos em que os contaminantes físicos, químicos ou biológicos que possam colocar em risco a saúde do consumidor, estão controlados.

Assim sendo, precisa-se a garantia de que o consumo destes seja seguro, e para isso temos um conjunto de normas de produção, transporte e armazenamento de alimentos, focando determinadas características físico-químicas, microbiológicas e sensoriais padronizadas, segundo as quais os alimentos seriam adequados ao consumo, que ratificam a Segurança alimentar. (SILVA, 2006)

Visando melhorias nas condições higiênico-sanitárias na preparação de alimentos a ANVISA e o Ministério da Saúde publicaram a Portaria no 1.428, estabelecendo pré-requisitos (Boas práticas) necessários para a implantação de qualquer sistema de qualidade.

A temperatura representa o mais importante dentre os fatores que podem influenciar no crescimento dos microrganismos em alimentos (CHESCA et al., 2001). A contaminação dos alimentos pode se iniciar na produção da matéria-prima e se estende às etapas de transporte, recepção, armazenamento e distribuição. O controle do tempo e temperatura e o manuseio correto são fatores básicos que influenciam diretamente na qualidade dos alimentos (SIMON, FREIMÜLLER E TONDO, 2001).

Em sistemas centralizados, em que as refeições são produzidas em uma cozinha central, transportadas a outros locais, uma vez que o alimento esteja dentro das condições adequadas de higiene, qualquer descuido na etapa de transporte poderá comprometer a segurança e a qualidade do produto. Durante a manipulação pode haver contaminação por condições precárias de higiene de manipuladores, equipamentos, utensílios e ambiente ou condições inadequadas de armazenamento dos produtos prontos para consumo (ZANDONI et al., 2007).

A distribuição dos alimentos é a etapa onde os alimentos são expostos para o consumo imediato (SILVA JR, 2007). Assim, a exposição prolongada dos alimentos a temperatura inadequadas é o principal fator de perda de controle sobre a multiplicação microbiana na etapa de distribuição. (MACEDO, 2010). Mesmo que um alimento tenha sido adequadamente preparado ou que tenha passado por tratamento térmico, onde todos ou parte dos microrganismos foram destruídos, sempre há um risco potencial de contaminação (GERMANO e GERMANO, 2011), principalmente se estes não permanecerem na faixa segura de temperatura.

Inconveniências com relação à armazenagem como a utilização de temperaturas incorretas e vedação insuficiente ou inexistente também são causas de contaminação de alimentos (OLIVEIRA et al., 2006). De acordo com a portaria CVS-6/99 a estufa de exposição, já limpa, deve ser mantida à temperatura de 65oㅡ, portanto, deve-se dar atenção ao controle térmico dos equipamentos e manter um registro deste controle, pois podem garantir a manutenção da temperatura adequada dos alimentos e dos locais onde são armazenados (MINISTÉRIO DA SAÚDE), uma vez que um controle inadequado desses fatores na cocção, resfriamento, processamento e armazenamento de alimentos é a principal causa da ocorrência de doenças transmitidas por alimentos - (DTAs) (DWINGER et al., 2007; WHO, 2007).

De acordo com Germano e Germano (2011), 79,2\% dos surtos de doenças de origem alimentar ocorreram em função da conservação inadequada de alimentos, onde o binômio tempo-temperatura foi desrespeitado, com exposição prolongada acima de $10^{\circ} \mathrm{C}$ ou próxima da temperatura ambiente. Em $83,5 \%$ das vezes, o intervalo entre o preparo e o consumo do alimento foi superior as 2 horas permanecendo entre $10^{\circ} \mathrm{C}$ e $60^{\circ} \mathrm{C}$.

0 objetivo do presente estudo foi monitorar e analisar a temperatura de quatro salgados quentes comercializados na padaria de um supermercado localizado em Florianópolis, SC. 


\section{METODOLOGIA}

Foi realizada uma pesquisa do tipo descritiva e exploratória, baseada por meio de levantamento bibliográfico. 0 presente trabalho foi desenvolvido com uma pesquisa de campo desempenhada em uma Unidade de Alimentação e Nutrição localizada em Florianópolis, SC. As análises foram feitas logo após a cocção, transporte até a exposição na estufa, e desta até o momento de venda, visando manter e alterar alguns padrões para que as condições adequadas de conservação de temperatura dos salgados, no âmbito segurança alimentar, fossem alcançadas.

Foram verificados dois salgados assados: empada de palmito e camarão; e dois fritos: coxinha e croquete de camarão.

Para o monitoramento da temperatura dos alimentos e das estufas foram utilizados dois termômetros: Tipo espeto, modelo TP101, com faixas de temperatura entre $-50^{\circ} \mathrm{C}$ e $300^{\circ} \mathrm{C}$; e digital infravermelho com mira laser, modelo GM-300, marca Fly, com faixa de temperatura entre -50 e $380^{\circ} \mathrm{C}$.

As temperaturas verificadas foram anotadas e analisadas numa planilha durante 10 dias, em dias alternados, no período de 27 de setembro a 1 de novembro de 2017, durante este, foram aplicadas as alterações necessárias para manter o alimento e os equipamentos na temperatura correta de acordo com a RDC 216.

\section{RESULTADOS}

Após a verificação das temperaturas no período de 27 de setembro até 18 de outubro em horários determinados, entre o final da cocção até a venda, conclui-se que os salgados se encontravam abaixo da temperatura adequada de segurança microbiológica (Gráfico 1).

Assim esta UAN pode ser um potencial veículo de transmissão de doenças causadas por alimentos e, portanto, o tempo e a temperatura se mostraram fatores muito importantes e devem ser monitorados constantemente em todas as fases do processo de produção.

Os principais fatores responsáveis pela temperatura inadequada foram: horários desajustados na produção dos salgados e posteriormente o tempo em que o alimento ficava exposto a temperatura ambiente, até a chegada do responsável pela manipulação e acondicionamento destes na estufa.

Durante a coleta e a verificação dos dados, alterações foram feitas para que essas falhas fossem corrigidas e reavaliadas.

Grafico 1 - Média das temperaturas dos salgados X temperatura da estufa X Horário das análises, analisadas no período de 27/09 até 18/10.

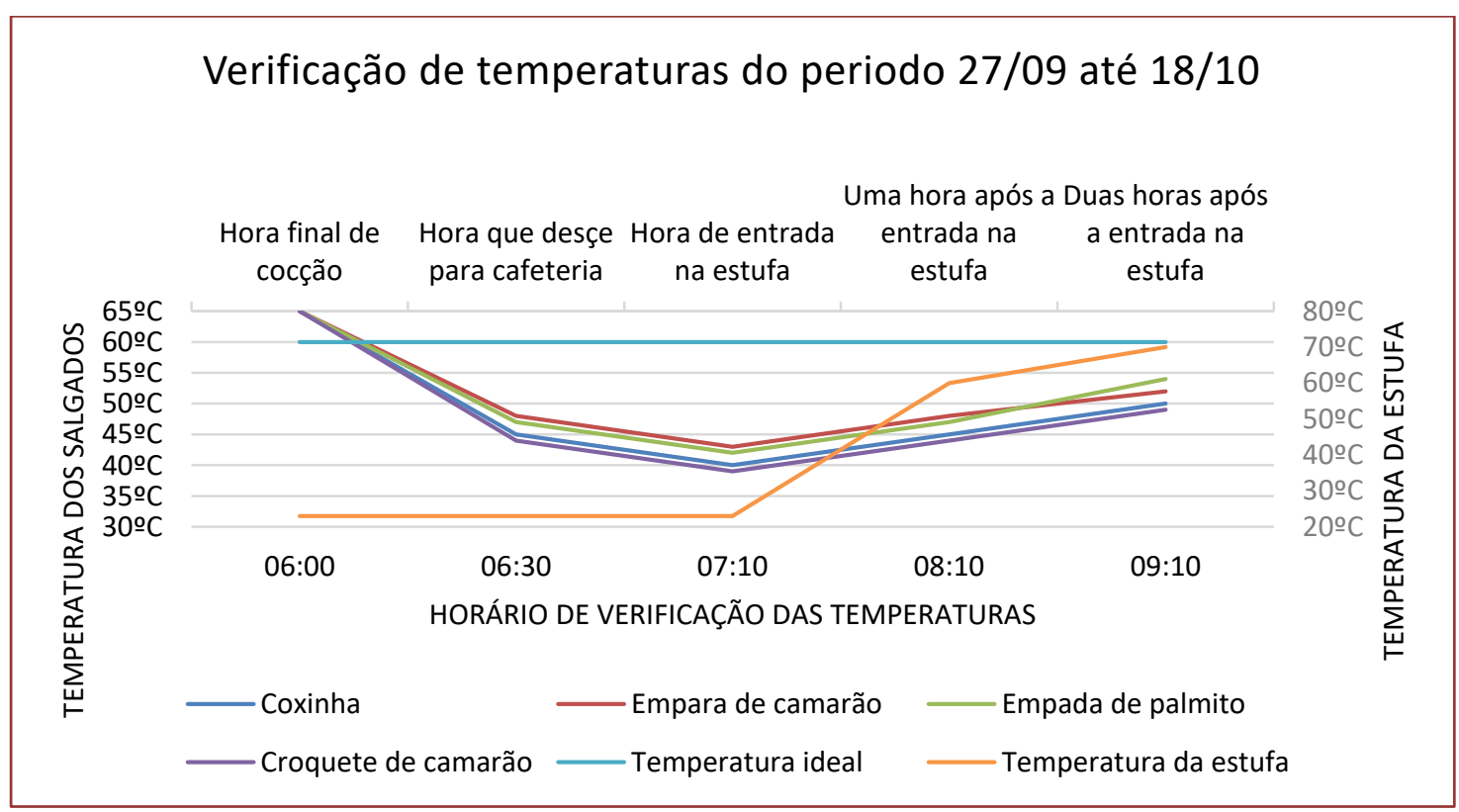


Foram feitas as correções necessárias, que incluíram: ajuste de horário por parte dos funcionários, preparação com pouca antecedência em relação à exposição para a venda e horário de acionamento das estufas conveniente com o tempo de chegada dos salgados.

Na nova análise (Gráfico 2) no período de 23 de outubro até 1 de novembro, foram constatadas que as alterações de armazenamento e horários ajustados foram positivas. As temperaturas dos salgados permaneceram constantes $\geq 60^{\circ} \mathrm{C}$ durante todo o intervalo analisado, o que garante a segurança dos salgados e os mantém qualitativamente sem riscos ao consumidor.

Gráfico 2 - Gráfico contendo as informações de temperatura da estufa X temperatura dos salgados em determinados horários da análise.

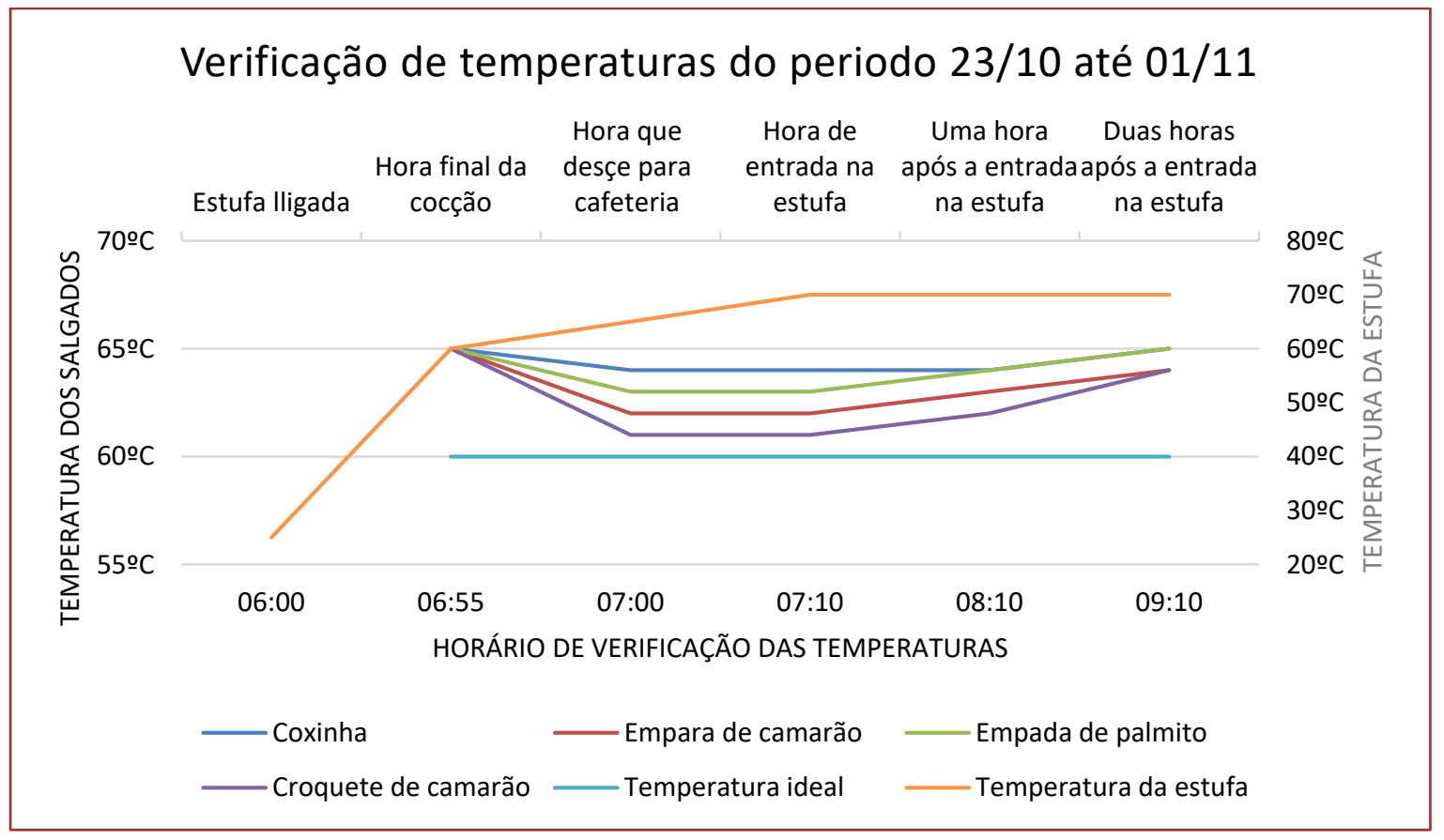

\section{DISCUSSÃO}

Dentro dos fatores que permitem a proliferação microbiana, a causa mais apontada pelos investigadores de surtos foi o prolongado tempo de exposição dos alimentos à temperatura ambiente. Já em relação aos fatores de sobrevivência dos patógenos, os mais citados são o tempo e a temperatura de cozimento insuficientes durante a cocção dos alimentos. (CDC, 2006; TAUXE, 2002; JD, MB, 2009). No caso do estudo exposto, a falha foi somente em relação à exposição inadequada a temperatura ambiente, quanto a insuficiência de tempo e temperatura durante a cocção, nada negativo foi constatado.

Durante a distribuição dos alimentos, sabe-se que o principal objetivo dos balcões térmicos, além de fornecer os produtos em temperatura agradável, é manter uma condição de temperatura e tempo seguros sob o ponto de vista microbiológico. Conforme a RDC 216, após serem submetidos à cocção, os alimentos preparados devem ser mantidos em condições de tempo e de temperatura que não favoreçam a multiplicação microbiana. A CVS 5, 2013 de São Paulo propôs normas para a conservação a quente, o alimento pode ficar a $65^{\circ} \mathrm{C}$ ou mais por no máximo 12 horas; e se estiverem abaixo de $60^{\circ} \mathrm{C}$, garantir que sejam consumidos em até 3 horas. A ANVISA, 2004, permite que um alimento fique a $60^{\circ} \mathrm{C}$ por no máximo 6 horas. Para o estado de Santa Catarina não há um regulamento técnico sobre boas práticas como em São Paulo, no caso a CVS 5/2013, no geral só o Manual ABERC dispõe sobre normas práticas de Elaboração e Serviço de Refeições para Coletividades.

Os salgados, após a cocção, não eram redirecionados imediatamente para as estufas, como o indicado pela RDC 216, mas sim, acondicionados no carinho de transporte de alimentos à temperatura ambiente, e só após uma hora eram expostos na estufa, porém, como o acionamento desta era feito no mesmo momento, os salgados continuavam a perder temperatura, até que se alcançasse a temperatura ideal do equipamento $\mathrm{X}$ alimento. 
No que diz respeito as resoluções da RDC 216 sobre os salgados e fritos, o estabelecimento mantém um monitoramento de temperatura específico para que o óleo das fritadeiras não ultrapasse $180^{\circ} \mathrm{C}$, caso ocorra, um sensor desliga o equipamento para que este não aqueça mais. Portanto, não foram identificadas características inadequadas nesse estudo específico.

Muitos alimentos são mantidos quentes em estufas de ar quente até o momento de serem comercializados. Todavia, quando o equipamento de aquecimento é malconservado ou utilizado de modo inadequado, o intervalo de tempo entre o preparo e o consumo favorece a incubação de eventuais agentes microbianos patogênicos, possibilitando a sua multiplicação ou a produção de toxinas (GERMANO e GERMANO, 2011).

Se o alimento estiver com a temperatura entre $10^{\circ} \mathrm{C}$ à $60^{\circ} \mathrm{C}$ o risco de proliferação de microrganismo do mesmo é bem grande, sendo que acima de $60^{\circ} \mathrm{C}$ há uma maior segurança na refeição. Mesmo conseguindo controla-la, deve haver um cuidado com o tempo em que estará exposto a temperatura ambiente, caso contrário o trabalho de controle será em vão, a perca de calor ocorrerá da mesma forma e a alimento ficará extremamente mais vulnerável a contaminação dos microrganismos presentes no ar tornando-a insegura para o consumo. (RICARDO; MORAIS; CARVALHO 2012).

Um estudo similar a este, sobre a qualidade microbiológica de alguns salgados, relatou que alimentos deixados em temperatura ambiente podem sofrer aumento da proliferação de microrganismos. Foi observado em 2 lanchonetes que a estufa permanecia desligada com a justificativa de economizar energia elétrica, nestas foram encontrados CSR e Salmonella sp em um salgado de carne e uma coxinha. Alimentos estes que deveriam ser mantidos em temperaturas acima de 65․

Já no estudo atual, na primeira fase das análises do presente estudo foi identificado uma falha semelhante, o acionamento tardio da estufa, o que ocasionava um aumento do tempo em que o alimento ficava exposto a uma temperatura inadequada mesmo acondicionado dentro do equipamento.

Não foram feitas análises de amostras microbiológicas no presente estudo, todavia, como foi citado, a negligência de alguns parâmetros de temperatura potencializa a chance de contaminação.

\section{CONCLUSÃo}

Diante dos resultados expostos, é possível concluir que não basta ter os equipamentos e realizar as verificações das boas práticas implantadas em uma cozinha, é preciso monitorar e analisar os dados verificados, buscando acima de tudo adequar o sistema de produção e distribuição de alimentos, garantindo a segurança alimentar do consumidor final.

Os resultados deste estudo indicam, que no processo produtivo desse supermercado específico, existiam lacunas sob a ótica da segurança e da qualidade quanto aos requisitos para produção e distribuição de alimentos. Nesse contexto, tendo em vista a importância dos manipuladores de alimentos nesse processo, a falta de planejamento da realização das diferentes etapas de preparo e distribuição dos salgados pelos funcionários responsáveis, possivelmente podem ter contribuído para o quadro encontrado inicialmente.

No entanto, após a análise dos dados coletados inicialmente, e aplicação das medidas corretivas no processo produtivo, entre elas a produção sem demasiada antecedência, e com o ajuste necessário de horários na realização das diferentes etapas de produção e distribuição pelos funcionários, o processo atingiu um nível satisfatório de qualidade e segurança que foram averiguados e ratificados nas análises posteriores, garantindo um alimento seguro para o consumidor.

\section{REFERÊNCIAS}

[1] Alves, ALMEIDA, Angela Teresinha Santiago. Monitoramento da temperatura de distribuição de preparações quentes em uma Unidade de Alimentação e Nutrição na cidade de Rio Grande. p.1; Rio Grande:2009.

[2] Brasil. Agência nacional de vigilância sanitária. Resolução RDC no 216, de 15 de setembro de 2004. Dispõe do Regulamento Técnico de Boas Práticas para Serviços de Alimentação.

[3] BRASIL. Ministério da Saúde. Resolução RDC no 216, de 15 de setembro de 2004, 2004. Disponível em: . Acesso em: 28 abr. 2008.

[4] CDC. Centers for Disease Control and Prevention, - CDC - Surveillance for Foodborne-Disease Outbreaks United States, 1998-2002. Morbidity and Mortality Weekly Report (MMWR) November, 2006.

[5] CHESCA, Ana Claudia. Avaliação das Temperaturas de Pistas Frias e Pistas Quentes em Restaurantes da Cidade de Uberaba/MG. Revista Higiene Alimentar. 2001; 15(87): 38-43. 
[6] DWINGER, R.H.; Golden, T.E.; Hatakka, M.; Daelman, W. Dtsch Tierarztl Wochenschr. Germany. v.114, n.8., 2007. Exposure assessment of street food vending in Johannesburg, South Africa.

[7] FORSYTHE, Stephen J. Microbiologia da segurança dos alimentos. 2.ed. Porto Alegre: Artmed, 2013

[8] GERMANO, Pedro Manuel Leal; GERMANO, Maria Izabel Simões. Higiene e Vigilância Sanitária de Alimentos. SãoPaulo: Varela,4 ed. 2011.

[9] GLAUCIA CRISTINA MACEDO, Projeto para monitoramento de temperatura na distribuição de salgados quentes; 2010.

[10] Greig JD, Lee MB. Enteric outbreaks in long -term care facilities and recommendations for prevention: a review. Epidemiol. Infect. 2009;137:145-55. International Journal of Food Microbiology 61, 137- 145, 2000.

[11] KAWASAKI, V.M.; Cyrillo, D.C.; Machado, F.M.S. Custo Efetividade da produção de refeições coletivas sob o aspecto higiênico-sanitário em sistemas cook-chill e tradicional. Revista de Nutrição. v.20, n.2, 2007

[12] LEE, Sarah Hwa In. QUALIDADE MICROBIOLÓGICA DE LANCHES E SALGADOS COMERCIALIZADOS EM BOTUCATU, SP. 2009. 18 f. TCC (Graduação) - Curso de Ciências Biológicas, Microbiologia e Imunologia, Universidade Estadual Paulista Júlio de Mesquita Filho, Botucatu, 2009.

[13] MINISTÉRIO DA SAÚDE. Secretaria de Vigilância em Saúde. Manual integrado de Prevenção e Controle de Doenças Transmitidas por Alimentos. p.70; 1996.

[14] MOSUPYE, F.M., VON HOLY, A. Microbiological hazard identification and

[15] RICARDO, Flávia Oliveira; MORAIS, Mariana Patrício de; CARVALHO, Ana Clara Martins e Silva. Controle de tempo e temperatura na produção de refeições de restaurantes comerciais na cidade de Goiânia-GO. rev. Demetra: Nutrição e saúde, v.7,n.2; p.85-96. 2012

[16] SILVA JR, Eneo Alves da. Manual de Controle Higiênico-Sanitário em Serviços de Alimentação. 7.ed; São Paulo:Varela, 2007.

[17] SIMON, M.I.S.S.; Freimüller, S.; Tondo, E.C.; Ribeiro, A.S.; Drehmer, M. Qualidade microbiológica e temperatura de dietas enterais antes e após implantação do sistema de análise de perigos e pontos críticos de controle. Revista de Nutrição. v.20, n.2, 2007.

[18] TAUXE RV. Emerging foodborne pathogens. International Journal of Food Microbiology. 2002;78:31-41.

[19] TRINDADE, Daiane Nieves; LEAL, Cynthia Munhoz dos Anjos; VIEIRA, Maria Fátima

[20] VENTIMIGLIA, Tamara de Moraes; BASSO, Cristiana. Tempo e temperatura na distribuição de preparações em um unidade de alimentação e nutrição. Santa Maria; rev.Ciências da Saúde,v. 9, n. 1, p. 109-114, 2008.

[21] WORLD HEALTH ORGANIZATION. The role of food safety in health and development. Genebra; 1984 


\section{Capítulo 19}

\section{Análise comparativa de preços entre hortifrutícolas orgânicas e convencionais na alimentação escolar}

\section{Bárbara Dorneles Pontes \\ Susana Berleze de Pelegrini \\ Carla Cristina Bauermann Brasil \\ Tiffany Prokopp Hautrive}

Resumo: 0 programa de alimentação escolar vem sendo modificado para melhorar a qualidade da alimentação servida. É possível observar a adequação aos hábitos alimentares e inclusão de alimentos frescos a partir do fortalecimento da economia local. O objetivo desta pesquisa foi identificar o preço de hortifrutícolas orgânicas em comparação aos convencionais em uma escola de educação infantil. 0 presente estudo constitui-se de abordagem quanti-qualitativa, de caráter exploratório e descritivo, sendo realizado uma pesquisa comparativa de preços, entre 17 hortifrutícolas de uma feira 100\% orgânica local de uma cidade do Rio Grande do Sul e hortifrutícolas da Central de Abastecimento do Estado do Rio Grande do Sul S/A. Através da análise, pode-se observar que os produtos orgânicos oriundos da feira livre são 107,68\% mais caros que os ofertados pela CEASA/RS. Apesar dos produtos orgânicos apresentarem um preço elevado, incluir os mesmos na alimentação escolar é fundamental para promover uma alimentação mais saudável e fomentar a economia local..

Palavras-chave: Alimentação Escolar; Alimentos Orgânicos; Controle de Custos; Agricultura Sustentável. 


\section{INTRODUÇÃO}

O Programa Nacional de Alimentação Escolar (PNAE), através de suas diretrizes, incentiva a alimentação saudável, que respeite a cultura, as tradições e os hábitos alimentares, desse modo, promovendo o desenvolvimento sustentável, com incentivos para a aquisição de gêneros alimentícios diversificados, sazonais e produzidos por agricultores locais (BRASIL, 2015).

O apoio a produção orgânica ou agroecológica oriunda de agricultores é fundamental para a geração de emprego e renda na região. Pois, além de fortalecer a economia, a aquisição desses produtos diminui o custo e o tempo com transporte, assim, garantindo alimentos frescos e in natura para a produção da alimentação escolar (RODRIGUES et al., 2017).

A aquisição de produtos orgânicos que não utilizam substâncias que coloquem em risco a saúde humana e o meio ambiente deve ser planejado, pois o aumento do custo com matéria-prima não deve comprometer outros gastos fixos de uma unidade de alimentação e nutrição (ABREU et al., 2016).

Em instituições públicas, o valor repassado pelo Fundo Nacional de Desenvolvimento da Educação do governo federal para a aquisição de gêneros alimentícios do programa de alimentação escolar é definido de acordo com o número de dias letivos, com a etapa e modalidade de ensino e o número de estudantes. Deste valor, 30\%, no mínimo, devem ser investidos na compra de produtos da agricultura familiar, com a finalidade de fomentar o desenvolvimento sustentável e econômico local (BRASIL, 2009). A efetuação da compra deve ser realizada através da Chamada Pública, que se caracteriza pelo procedimento administrativo voltado à seleção de proposta específica para aquisição desses gêneros alimentícios (Brasil, 2015). Assim, o estudo torna-se pertinente para identificar o custo de hortifrutícolas orgânicos em comparação aos convencionais através de uma análise que visa inserir as hortifrutícolas orgânicas da agricultura familiar no cardápio da alimentação escolar.

\section{MATERIAL E MÉTODOS}

O presente estudo constitui-se de abordagem quanti-qualitativa, de caráter exploratório e descritivo, sendo realizado uma pesquisa comparativa de preços entre 17 hortifrutícolas de uma feira orgânica realizada em uma cidade da região central do Rio Grande do Sul e hortifrutícolas convencionais da Central de Abastecimento do Estado do Rio Grande do Sul S/A (CEASA/RS).

A coleta de dados dos preços das hortifrutícolas orgânicas foi realizada in loco em uma feira que reúne agricultores da região, certificados em processo de reconhecimento pelo Ministério da Agricultura. Já a coleta dos preços das hortifrutícolas da CEASA/RS foi realizada através da plataforma eletrônica destinada ao comércio, referentes à cotação diária e o preço máximo do dia (CEASA/RS, 2019).

O estudo foi elaborado com o intuito de inserir alimentos orgânicos oriundos da agricultura familiar em uma escola de educação infantil federal da região central do RS. Cabe destacar que a atual aquisição de hortifrutícolas da escola ocorre, principalmente, através da CEASA/RS.

Após a coleta e tabulação de dados realizou-se à análise estatística descritiva simples (média e percentual), com o auxílio do programa Microsoft Office Excel, versão 2007.

\section{RESULTADOS E DISCUSSÃO}

Através da análise dos preços, pode-se observar que os produtos orgânicos oriundos da feira livre são cerca de 107,68\% mais caros que os da CEASA/RS (QUADRO 1). Resultado semelhante foram encontrados por Santos et al. (2015), que realizaram uma pesquisa comparativa de preços entre produtos orgânicos e convencionais em um supermercado em Olinda-PE. Os dados verificados pelos autores deste estudo constataram que os produtos orgânicos, como, o limão, tangerina, café e suco, são cerca de 106,69\% mais caros que os convencionais. Esse elevado custo pode ocorrer devido às múltiplas causas que a produção orgânica requer, como, a exigência de mais mão-de-obra, menor rendimento em comparação com os convencionais e custos adicionais em certificação, transporte e distribuição decorrente da baixa escala de produção (DAROLT, 2015). 
Quadro 1 - Quadro comparativo entre as hortifrutícolas oriundas da feira orgânica local e das hortifrutícolas convencionais da Central de Abastecimento do Estado do Rio Grande do Sul S/A CEASA/RS.

\begin{tabular}{|c|c|c|c|c|c|}
\hline \multicolumn{2}{|c|}{ Hortifrutícolas } & $\begin{array}{c}\text { Média dos custos } \\
\text { das hortifrutícolas } \\
\text { orgânicas }\end{array}$ & $\begin{array}{c}\text { Média dos custos das } \\
\text { hortifrutícolas } \\
\text { ceasa/rs }\end{array}$ & \multicolumn{2}{|c|}{$\begin{array}{c}\text { Diferença de preço Entre as } \\
\text { hortifrutícolas orgânicas e } \\
\text { ceasa/rs }\end{array}$} \\
\hline Itens & Unid. & Custo $(r \$)$ & Custo (r\$) & Custo (r\$) & $(\%)$ \\
\hline Alface americana & Dúzia & 24,00 & 18,00 & 6,00 & 33,33 \\
\hline Alface & Dúzia & 27,00 & 15,00 & 12,00 & 80,00 \\
\hline Alho & $\mathrm{Kg}$ & 7,14 & 15,00 & $-7,86$ & $-52,40$ \\
\hline Arroz integral & $\mathrm{Kg}$ & 5,00 & 3,95 & 1,05 & 26,58 \\
\hline Banana Prata & $\mathrm{Kg}$ & 3,00 & 1,50 & 1,50 & 100,00 \\
\hline Beterraba & $\mathrm{Kg}$ & 2,50 & 1,15 & 1,35 & 117,39 \\
\hline Brócolis & Dúzia & 38,00 & 20,00 & 18,00 & 90,00 \\
\hline Cenoura & $\mathrm{Kg}$ & 4,32 & 1,30 & 3,02 & 231,92 \\
\hline Cheiro-verde & Dúzia & 10,80 & 6,00 & 4,80 & 80,00 \\
\hline Couve & Dúzia & 25,50 & 10,00 & 15,50 & 155,00 \\
\hline Espinafre & Dúzia & 30,00 & 18,00 & 12,00 & 66,67 \\
\hline Laranja suco & $\mathrm{Kg}$ & 2,00 & 1,20 & 0,80 & 66,67 \\
\hline Mandioca descascada & $\mathrm{Kg}$ & 8,00 & 4,00 & 4,00 & 100,00 \\
\hline Morango & $\mathrm{Kg}$ & 20,00 & 15,00 & 5,00 & 33,33 \\
\hline Pepino salada & $\mathrm{Kg}$ & 6,00 & 1,50 & 4,50 & 300,00 \\
\hline Repolho verde & $\mathrm{Kg}$ & 2,05 & 0,50 & 1,55 & 310,00 \\
\hline Rúcula & Dúzia & 28,80 & 15,00 & 13,80 & 92,00 \\
\hline \multicolumn{2}{|l|}{ TOTAL } & 215,31 & 132,10 & 83,21 & 107,68 \\
\hline
\end{tabular}

Fonte: Autores, 2017.

Dentre os produtos analisados no presente estudo, 41,10\% (n=7) das hortifrutícolas orgânicas apresentaram percentual de diferença dos custos acima de 100\%. Os maiores percentuais encontrados foram em relação ao custo do repolho verde e do pepino salada, pois os produtos orgânicos apresentaramse mais caros que os da CEASA/RS. Essas diferenças podem ter ocorrido devido à dificuldade, custos e individualidade que cada produto orgânico requer durante a produção, tais fatores, influenciam diretamente no preço que é repassado ao consumidor (DAROLT, 2015). Em contrapartida, o alho adquirido da CEASA/RS é mais caro do que o orgânico. Os alimentos que tiveram a mínima diferença entre os dois comparativos foram o morango e a alface americana.

Para Abreu et al. (2016), o bom funcionamento de uma unidade de alimentação e nutrição depende, dentre outros fatores, de um correto sistema de análise e de informações de custos. Sendo que, o aumento com gastos de matérias-primas não deve comprometer o rendimento financeiro da unidade e ultrapassar os custos orçados.

Apesar do elevado custo das hortifrutícolas orgânicas, em comparação com as adquiridos da CEASA/RS, a inserção dos orgânicos no cardápio da escola de educação infantil analisada iria garantir à oferta de alimentos frescos e sem adição de produtos químicos utilizados na agricultura. Além disso, atende a diretriz estipulada pelo PNAE, que incentiva a aquisição de gêneros alimentícios produzidos em âmbito local e preferencialmente pela agricultura familiar.

Embora os produtos orgânicos sejam mais caros, torna-se sustentável inserir os alimentos nos cardápios dos escolares de acordo com a sazonalidade, visto que os alimentos orgânicos tornam a alimentação escolar mais saudável, além de fomentar o comércio local (SILVA; SOUSA, 2013).

A implantação das novas diretrizes do PNAE que insere a agricultura familiar, local e regional na alimentação escolar, tem o papel de favorecer grande transformação na realidade dos municípios. Além de promover a segurança alimentar e nutricional às crianças e adolescentes em idade escolar, o incentivo ao consumo de produtos naturais locais cria um novo canal de aprendizagem aos escolares sobre a importância do cardápio variado, que respeite a cultura regional e os hábitos alimentares saudáveis (RODRIGUES et al., 2017). 


\section{CONCLUSÃO}

Apesar dos produtos orgânicos avaliados apresentarem um preço elevado em comparação com os convencionais adquiridos da CEASA/RS, a inclusão dos mesmos na alimentação escolar é fundamental para promover uma alimentação diversificada, saudável e querespeite a cultura local.

Para ocorrer a inserção gradual das hortifrutícolas orgânicas e cumprir as propostas do PNAE é necessário que ocorra o planejamento de custos pelos gestores da unidade e, que os agricultores estejam cadastrados no programa da agricultura familiar aptos a fornecerem a quantidade necessária para a produção de alimentos de acordo com a sazonalidade.

\section{REFERÊNCIAS}

[1] ABREU, E. S., SPINELLI, M. G. N., \& PINTO, A. M. S. (2016). Gestão de unidades de alimentação e nutrição: um modo de fazer (6. ed.). São Paulo: Editora Metha.

[2] BRASIL. Conselho Nacional de Segurança Alimentar e Nutricional. (2004). Princípios e diretrizes de uma política de segurança alimentar e nutricional: textos de referência da II Conferência de Segurança Alimentar e Nutricional. Conselho Nacional de Segurança Alimentar e Nutricional, Brasília.

[3] BRASIL. Ministério da Educação. Fundo Nacional de Desenvolvimento da Educação (FNDE). (2009). Lei no 11.947, de 16 de junho de 2009. Dispõe sobre o atendimento da alimentação escolar e dá outras providências. Diário Oficial [da] República Federativa do Brasil, Brasília, DF, 16 jun., 2009.BRASIL. Ministério da Educação. Fundo Nacional de Desenvolvimento da Educação (FNDE). (2015). Aquisição de produtos da agricultura familiar para a alimentação escolar - versão atualizada com a Resolução CD/FNDE no 04/2015 ed. 2. Ministério da Educação.

[4] CEASA/RS - CENTRAIS DE ABASTECIMENTO DO RIO GRANDE DO SUL (2019). Cotação 2019. Disponível em: http://www.ceasa.rs.gov.br/cotacao.php.

[5] DAROLT, M. R. (2015). Guia do Consumidor Orgânico. Como reconhecer, escolher e consumir alimentos saudáveis. Rio de Janeiro: Sociedade Nacional de Agricultura; Serviço Brasileiro de Apoio às Micro e Pequenas Empresas; Centro de Inteligência em Orgânicos.

[6] RODRIGUES, R., SIQUEIRA, H. D. DE., BIANCARDI, C. C. S., ANDRADE, M. A. N., VALENTE, L. M., \& PAULA, L. B. DE. (2017). A aquisição de alimentos da agricultura familiar pelo PNAE no município de Alegre-ES. Demetra, 12(1), 91-112.

[7] SANTOS, N. L., BARBOSA, G. F., SANTOS, R. L., COSTAS, C. M. S., \& MOURA, M. J. A. (2015). Análise comparativa de preços entre produtos orgânicos e convencionais em um supermercado e hortifrúti em Olinda-PE. Congresso Técnico Científico da Engenharia e da Agronomia - CONTECC'2015, Fortaleza, CE.

[8] SÃo PAULO. Governo do Estado de São Paulo. (2015). Sazonalidade dos Alimentos. Secretaria da Fazenda.

[9] SILVA, A. P. F., \& SOUSA, A. A. (2013). Alimentos orgânicos da agricultura familiar no Programa Nacional de alimentação Escolar do Estado de Santa Catarina, Brasil. Revista de Nutrição, 26(6), 701-714. 


\section{Capítulo 20}

\section{Avaliação das condições higiênico-sanitárias em um estoque de armazenamento de alimentos de uma escola do Município de Seropédica/RJ}

\section{Maria Rosa Figueiredo Nascimento \\ Yzadora Maura de Figueiredo \\ Ronel Joel Bazán Colque}

Resumo: A Unidade de Alimentação e Nutrição - UAN é uma unidade de trabalho que desempenha e fornece alimentos com boas qualidades nutricionais, sensórias e higiênico-sanitárias. A UAN foi criado no 1939, obrigando as empresas com mais de 500 empregados a instalar refeitórios para os mesmos no local de trabalho. Para garantir as condições higiênico-sanitárias é preciso aplicar as Boas Práticas de Fabricação - BPF, que consistem numa série de práticas higiênicas recomendadas durante o manuseio de alimentos visando obter produtos seguros para o consumo. 0 objetivo geral deste estudo de casos é avaliar as condições higiênico-sanitárias de armazenamento num estoque de uma escola do Município de Seropédica. 0 estudo foi realizado nos meses de setembro a novembro de 2014. Os dados foram coletados mediante a aprovação prévia da responsável técnica da UAN. O levantamento dos dados foi realizado por observação direta e verificação documental, utilizando-se um check list, determinados pela Resolução RDC no 216. As questões abordadas no check list se refere ao estoque de alimentos. Os resultados revelaram muitas não conformidades (50\%) no diagnóstico inicial como instalações, higiene, controle, conservação e ambiência. Por tanto foi recomendado a melhorar as condições higiênico-sanitárias de armazenamento como a limpeza diária nos equipamentos e instalações, controle de vetores e treinamento aos colaboradores.

Palavras-chave: Segurança alimentar, boas práticas, armazenamento de alimentos, condições higiênico-sanitárias, conservação de alimentos. 


\section{INTRODUÇÃO}

Unidade de Alimentação e Nutrição - UAN é uma unidade de trabalho que tem por finalidade desempenhar atividades relacionadas a alimentação e nutrição, fornecendo alimentos com boas qualidades nutricionais, sensoriais e higiênico-sanitárias (TEIXEIRA et al., 2004).

No Brasil, as UANs iniciaram no governo de Getúlio Vargas, que em 1939 decretou a lei número 1238 obrigando as empresas com mais de 500 funcionários a instalar refeitórios para os mesmos no local onde se concentrava a força de trabalho. Desse momento em diante, os processos relacionados à preparação de alimento evoluíram e surgiram as primeiras empresas portadoras de serviços na área de alimentação industrial. Inicialmente, as próprias empresas eram responsáveis pela aquisição, processamento e distribuição das refeições aos seus funcionários, sem se preocupar em geração de lucros ou conter recursos. Com o tempo, criaram-se uma serie de empresas em prestação de serviços em UANs, que eram responsáveis pela aquisição da matéria prima, transformação e distribuição das refeições para seu público interno (RIBEIRO, 2002).

As UANs têm como objetivo principal preparar e fornecer refeições equilibradas em nutrientes, de acordo com o perfil do cliente. Conceitualmente, pode ser considerada como unidade ou órgão de uma empresa, responsável pela alimentação e nutrição dos funcionários, independentemente da situação que ocupa na escala hierárquica (RICARTE et al., 2008). De acordo com a legislação nacional, toda UAN é obrigada a seguir normas e padrões que estabeleçam condições higiênico-sanitárias para manipulação e processamento de alimentos, sendo assim foram estabelecidas pelo FDA (Food and Drug Adiministration) as chamadas Boas Práticas de Fabricação - BPF, que consistem numa série de práticas higiênicas recomendadas durante o manuseio de alimentos, visando a obtenção de produtos seguros para o consumo e nelas estão incluídas todas as etapas de fabricação. As Boas Práticas - BP’s não garantem a segurança e a qualidade dos produtos, mas estabelece normas para o controle higiênico-sanitário dos mesmos. AS BP`s possuem grande campo de aplicações incluindo processo e controle das instalações para todas as etapas; produção, armazenamento, e distribuição dos alimentos (ANVISA, 2002b).

A alimentação no âmbito institucional apresenta a importante tarefa de manutenção da saúde do potencial humano dos estudantes e, por conseguinte, possibilitar um melhor desempenho de suas atividades, por isso as refeições produzidas na UAN escolar devem seguir um padrão elevado de qualidade higiênicosanitária e nutricional, seguindo rigorosamente as BP's em segurança alimentar. Por tanto o objetivo geral deste estudo de casos é avaliar as condições higiênico-sanitárias de armazenamento num estoque de uma escola do Município de Seropédica. Para manter este controle faz-se necessário seguir as leis estabelecidas pela Agencia Nacional de Vigilância Sanitária - ANVISA e para auxiliar na fiscalização dessas foi utilizado como ferramenta a aplicação de um check-list, tomando como base a RDC 216-2004 e a Lista de Verificação das Boas Práticas de Fabricação e Procedimentos Operacionais Padronizados RDC 275/2002 (ANVISA, 2004).

\section{REFERENCIAL TEÓRICO}

\subsection{CONTROLE HIGIÊNICO-SANITÁRIO}

Para uma UAN manter um controle higiênico-sanitário eficiente é necessário seguir leis estabelecidas pela ANVISA. Um dos instrumentos para a qualidade é a elaboração e implantação do Manual de Boas Práticas MBP que é fundamental para a produção de alimentos com qualidade, tanto do ponto de vista nutricional quanto em relação à segurança alimentar (ANVISA, 2004).

A segurança alimentar e nutricional consiste na realização do direito de todos ao acesso regular e permanente a alimentos de qualidade, em quantidades suficientes, sem comprometer o acesso a outras necessidades essenciais, tendo como base práticas alimentares promotoras de saúde que respeitem a diversidade cultural e que seja ambiental econômica e socialmente sustentável. A preocupação com a qualidade e a estrutura é ainda maior quando se oferece alimentação coletiva, principalmente quando se trata de escolas e centro de educação infantil, onde oferecem merenda escolar (SILVA JUNIOR, 2001). Pois na infância a nutrição adequada é essencial para promover crescimento e desenvolvimento normais e manutenção da saúde, sendo este estágio da vida biologicamente mais vulnerável a contaminação por doenças transmitidas por alimentos (MENEGAZZO et al., 2011). Sendo assim a segurança alimentar deve ser garantida, através das BPs em segurança alimentar, que buscam minimizar os perigos microbiológicos que são as principais causas de contaminação dos alimentos, proporcionando um alimento seguro, ou seja, um alimento inócuo à saúde humana, livre de contaminações físicas, químicas e/ou biológicas, 
Sendo assim a avaliação das condições do estoque do Cetro de Assistência Integrada a Criança-CAIC Paulo Dacorso Filho é muito importante para garantir que os alunos consumam alimentos com segurança e livre de contaminação e para prevenir que ocorra possíveis surtos de doenças no colégio.

A higiene do ambiente, equipamentos e utensílios, conforme orientação do (CODEX ALIMENTARIUS, 2006) os estabelecimentos alimentares devem ser construídos com material durável, de fácil manutenção, limpeza e desinfecção. São sugeridas as seguintes condições para proteger a segurança e adequação dos alimentos: As superfícies das paredes, divisórias e pisos devem ser de materiais impermeáveis que não produzem efeitos tóxicos para o uso a que se destinam; as paredes e as divisórias devem ter superfícies lisas até uma altura apropriada para as operações; os pisos devem ser construídos de modo a permitir drenagem e limpeza adequada, os tetos e os acessórios superiores devem ser construídos e revestidos de forma de minimizar o acumulo de poeira, a condensação e o desprendimento de partículas; as janelas devem ser de fácil limpeza, sendo construídas de forma a minimizar o acumulo de poeira e ser providas de telas removíveis contra insetos para facilitar a limpeza.

A RDC 216/2004 exige que os equipamentos, móveis e utensílios que entram em contato com alimentos sejam de materiais que não transmitam substancias toxicas, odores, nem sabores aos mesmos. Eles devem ser mantidos em adequado estado de conservação e ser resistente à corrosão e a repetidas operações de limpeza e desinfecção. A localização deve, sempre que possível, localizar-se em pavimento térreo, de forma a proporcionar fácil acesso externo para abastecimento, iluminação natural e ótimas condições de ventilação. Na impossibilidade de localização no andar térreo, sugere-se a instalação de elevadores e/ou monta-cargas específicos. A iluminação deve ser distribuída uniformemente pelo ambiente, evitando ofuscamentos, sombras, reflexos fortes e contrastes excessivos. Deve incidir em uma direção que não prejudique os movimentos nem a visão dos manipuladores. As janelas ou outros tipos de aberturas de estar disposta de maneira que não permitam a penetração direta do sol sobre a superfície de trabalho (ANVISA, 2004; MANZALLI, 2010).

De acordo com ANVISA (2004) a iluminação da área de preparação deve proporcionar a visualização de forma que as atividades sejam realizadas sem comprometer a higiene e as características sensoriais dos alimentos. As luminárias localizadas sobre a área de preparação dos alimentos devem ser apropriadas e estar protegidas contraexplosão e quedas acidentais.

A ventilação, a temperatura e a umidade estão implicitamente interligadas. Segundo Teixeira (2004), a ventilação deve ser adequada para propiciar a renovação do ar, garantindo o conforto térmico. A circulação do ar deve ser assegurada por meios naturais ou por equipamentos devidamente direcionados, não sendo permitido uso de ventiladores nas áreas de processamento e manipulação de alimentos.

Segundo Manzalli (2010) a temperatura ideal para uma UAN e de $22{ }^{\circ} \mathrm{C}$ a $26{ }^{\circ} \mathrm{C}$, com umidade relativa de $50 \%$ a 60\%. A ABERC (2008) ressalta a importância das cores no local de trabalho, recomendando a utilização de cores claras, como branco, creme, areia e outras, pois estas facilitam a identificação de sujidades e bolores. 0 piso deve ser de cor clara e mantida em bom estado de conservação, constituído de material liso, antiderrapante, impermeável, lavável, resistente ao tráfego e ao ataque de substâncias corrosivas e de fácil higienização (ABERC, 2008). De acordo com Zanella e Candido (2002) recomenda-se uma cobertura de concreto com revestimento antiderrapante, não poroso, resistente aos impactos de choques, impactos e pesos, com resistência para gorduras e ácidos. As paredes devem ser lisas, em cores claras, duráveis, impermeáveis e resistentes a limpezas frequentes. É recomendável que sejam revestidas com azulejos com altura mínima de 2 metros, devendo estar livres de falhas, rachaduras, umidade, bolor e descascamento.

De acordo ANVISA (2004) as portas e as janelas devem ser mantidas ajustadas aos batentes. As portas da área de preparação e armazenamento de alimentos devem ser dotadas de fechamento automático e as aberturas externas das áreas de armazenamento e preparação devem ser providas de telas milimetradas para impedir o acesso de vetores e pragas urbanas. As paredes e divisórias também devem ser de cores claras, com acabamento liso, possuindo características duráveis e impermeáveis, resistentes a limpezas frequentes, livres de fungos e bolores, as telas milimétricas colocadas nas janelas devem ser removíveis para facilitar a limpeza periódica.

\subsection{OUTRAS INSTALAÇÕES}

ANVISA (2004) menciona que as instalações elétricas devem estar embutidas ou protegidas em tubulações externas e íntegras de tal forma a permitir a higienização dos ambientes. 
De acordo com ANVISA (2004), as instalações sanitárias e vestiário não devem se comunicar diretamente com a área de manipulação e armazenamento de alimentos ou refeitórios, devendo ser mantidos organizados e em adequado estado de conservação. As portas externas devem ser dotadas de fechamento automático. As caixas de gordura e esgoto devem possuir dimensão compatível com o volume de resíduos, devendo estar localizados fora da área de preparação e armazenamento de alimentos e apresentar adequado estado de conservação e funcionamento. A periodicidade para a higienização nas caixas de gordura é 6 meses.

De acordo com Zanella e Candido (2002), os ralos devem ter abertura ou superfície ampla e com grade de metal, em posição e local que facilite o escoamento. A água utilizada para o consumo direto ou no preparo dos alimentos deve ser controlada independente das rotinas de manipulação dos alimentos. É obrigatória a existência de reservatório de água. 0 reservatório deve estar isento de rachaduras e sempre tampado, devendo ser limpo e desinfetado a cada 6 meses (Portaria CVS-6/99).

\subsection{ESTRUTURA FÍSICA}

Não se pode deixar de ressaltar que a estrutura física de uma UAN também e muito importante para o controle higiênico, pois a estrutura física da UAN, bem como o seu processo de manipulação, deve seguir um fluxo adequado e ininterrupto, o dimensionamento da edificação e das instalações, sempre continuo assim evita-se que ocorra a contaminação cruzada. Segundo Teixeira et al. (2004), o planejamento da estrutura física é muito importante e feito com uma série de detalhes, que se forem esquecidos, causarão uma série de transtorno na execução do trabalho, ou que haja necessidade da reestruturação do ambiente, causando perda de tempo e dinheiro.

Um dos pontos essenciais para suporte e garantia da implementação das boas práticas e qualidade dos alimentos preparados em Serviços de Alimentação é a adequação de edificação, instalações, equipamentos, móveis e utensílios. Essa adequação é essencial para a melhoria da qualidade higiênico-sanitária, nutricional e sensorial das refeições servidas e para o atendimento da legislação vigente. A edificação e as instalações devem ser projetadas de forma a possibilitar um fluxo ordenado e sem cruzamentos em todas as etapas da preparação de alimentos, e facilitar as operações de manutenção, limpeza e desinfecção (ROSSI, 2006).

Figura 1. Fluxograma das instalações.

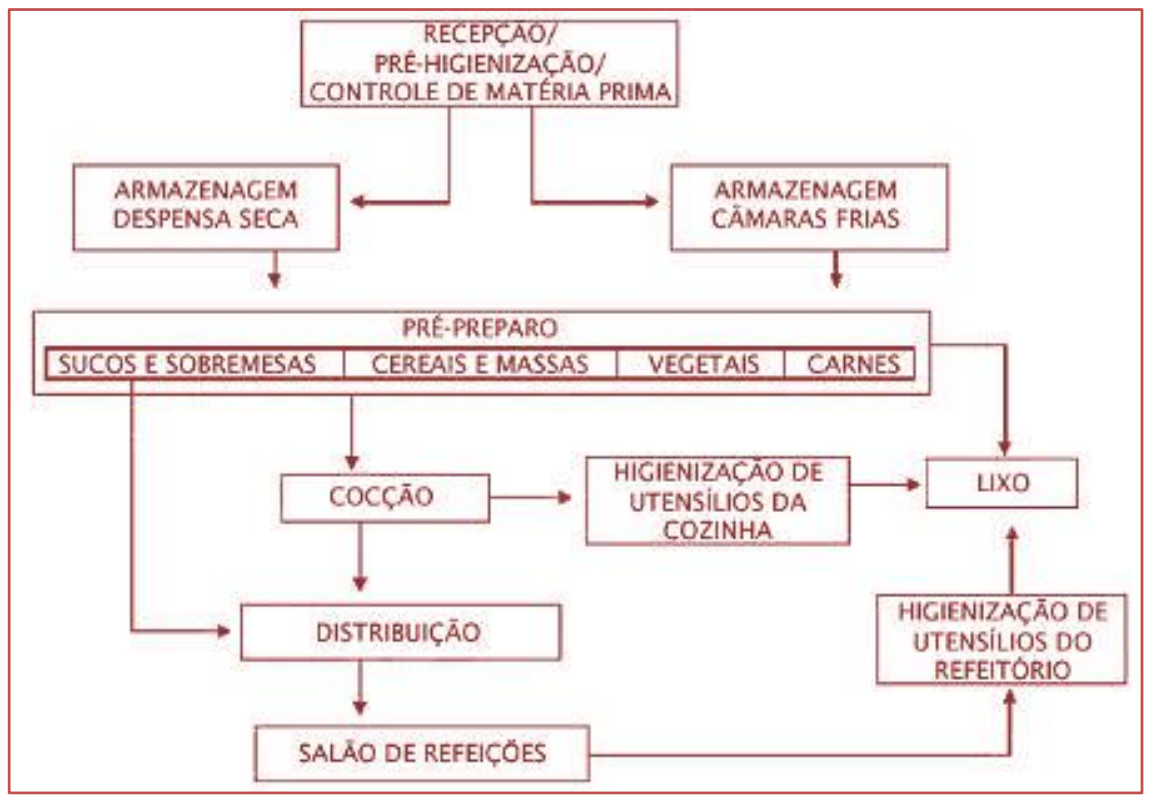

Fonte: HEBA (2015).

As áreas de uma Unidade de Alimentação e Nutrição são designadas para o preparo de refeições de coletivos, e para um bom funcionamento deve ser planejada seguindo uma linha racional de produções. 
Área de recebimento, uma UAN necessita de uma área própria para o recebimento de mercadorias situada, de preferência, em áreas externas ao prédio à estocagem. Deve ser de fácil acesso aos fornecedores e provida de plataforma de descarga, rampa e marquise para a proteção dos produtos na hora da entrega, e não deve haver cruzamento de matéria-prima com a saída do lixo (MANZALLI, 2010).

Área de armazenamento ambiente, de acordo a Manzalli (2010) é de total importância para esta área os seguintes itens: porta única, largas e altas com molas simples, borracha de vedação na parte inferior das portas, piso em material lavável e resistente, boa iluminação, ausência de ralos para escoamento de agua, ventilação cruzada ou mecânica, janelas e aberturas teladas, temperatura não superior a $26{ }^{\circ} \mathrm{C}$, umidade relativa do ar entre 50 a $60 \%$, inexistência de tubulação de agua e vapor, prateleiras localizadas a $25 \mathrm{~cm}$ do piso com profundidade não superior a $45 \mathrm{~cm}$, estrados para sacarias e locais distintos para armazenamento de produtos de limpeza e descartáveis.

$\mathrm{Na}$ área de armazenamento os alimentos devem ser separados por grupos. Não deve existir entulho ou material tóxico no estoque. Os alimentos devem ser posicionados com utensílios exclusivos e após sua utilização, as embalagens devem ser fechadas adequadamente. No estoque não deve existir equipamentos que propiciem condições que interfiram na qualidade e nas condições sensoriais dos alimentos. (PORTARIA CVS-6, 1999)

Área de armazenamento a temperatura controlada, esta área destina-se ao armazenamento de alimentos perecíveis ou rapidamente deterioráveis. Os equipamentos de refrigeração e congelamento devem ser de acordo com a necessidade e tipos de alimentos a serem produzidos ou armazenados (PORTARIA CVS-6, 1999). Como há uma grande variedade das características dos alimentos utilizados, recomenda-se a instalação de câmaras frigoríficas ou refrigeradores em número suficiente para atender a conservação de: Carnes: $4{ }^{\circ} \mathrm{C}$; Sobremesas, massas e produtos prontos até $4{ }^{\circ} \mathrm{C}$; frios e laticínios até $8{ }^{\circ} \mathrm{C}$; hortifrutigranjeiros; até $10^{\circ} \mathrm{C}$. É importante ressaltar que o ideal é que esses gêneros devem ser armazenados separadamente. Entretanto, no caso de possuir apenas uma câmara ou refrigerador, a temperatura deve ser regulada para o alimento que requeira menor temperatura (MANZALLI, 2010).

Segundo a PORTARIA CVS-6 (1999) no caso de o estoque possuir câmaras, estas devem apresentar as seguintes características: antecâmara para proteção térmica, revestimento com material lavável e resistente, nível do piso igual ao da área externa, termômetro permitindo a leitura pelo lado externo, interruptor de segurança localizado na parte externa da câmara, com lâmpada piloto indicador "ligado desligado", prateleiras em aço inox ou outro material apropriado, porta que permita a manutenção da temperatura interna e dispositivo de segurança que permita abri-la por dentro, quando utilizar porta hermética.

Área de pré-preparo e preparo, são as operações preliminares de confecção de preparações que incluem lavar, descascar, escolher, fatiar, aparar e picar. Segundo Silva Junior (2001) para cada tipo de produto a ser manipulado, deverá haver áreas e mesas separadas e específicas, para que os serviços tenham um melhor desenvolvimento e os produtos finais de melhor qualidade. Para Oliveira e Nery (1986) as áreas destinadas a estas operações são subdivididas para os vegetais, as carnes, as sobremesas e as pequenas refeições. Recomenda-se, portanto que a localização destas seja adjacente às câmaras frigoríficas, próximo à despensa e à área de cocção. A ABERC (2008) e Oliveira e Nery (1986), consideram que todas as áreas de pré-preparo e preparo deve ser constituído de bancada com tampo inox ou outro material adequado e balcões com cubas. As áreas destinadas às carnes vermelhas aves e pescados devem ser dotados de balcão com pia dupla, mesa de trabalho e equipamentos específicos. Já aquelas destinadas aos vegetais devem ser confeccionadas em área que possua balcão com pia, trituradores de lixo (se possível), equipamentos (como descascadores), mesa e placas de polietileno para corte de frutas e hortaliças. De acordo com ABERC (2008) a área de cocção é o local onde os alimentos são cozidos, fritos, grelhados ou assados. Recomenda que esta área esteja situada entre a área de preparo prévio e a de expedição dos equipamentos, seguindo um fluxo racional. É importante que esta área disponha de pia exclusiva para lavagem das mãos dos manipuladores. Nesta área deve haver somente equipamentos destinados ao preparo de alimentos quentes, não devendo ter refrigeradores ou congeladores porque o calor excessivo compromete o funcionamento de seus motores.

\subsection{CONTROLE INTEGRADO DE VETORES E PRAGAS URBANAS}

A resolução RDC 52/09 define controle de vetores e pragas urbanas como um conjunto de ações preventivas e corretivas de monitoramento ou aplicação, ou ambos com periodicidade minimamente 
mensal, visando impedir de modo integrado que vetores e pragas urbanas se instalem ou reproduzam no ambiente (ANVISA, 2004).

A resolução 275/02 que regulamenta a obrigatoriedade dos procedimentos operacionais padronizados explica que Controle Integrado de Pragas é um sistema que incorpora ações preventivas e corretivas destinadas a impedir a atração, o abrigo, o acesso e ou proliferação de vetores e pragas urbanas que comprometam a segurança do alimento (ANVISA, 2004).

Ao analisarmos as Boas Práticas para Serviços de Alimentação, conforme a RDC no216/04, temos contribuições significativas para a prevenção de ocorrências de pragas urbanas, a saber, o item 4.1.3 - "as instalações físicas como piso, parede e teto devem possuir revestimento liso, impermeável e lavável". Devem ser mantidos íntegros, conservados, livres de rachaduras. Trincas, goteiras, vazamento, infiltrações, bolores, descascamentos, dentre outros e não devem transmitir contaminantes aos alimentos" (ANVISA, 2004).

\section{METODOLOGIA}

O trabalho caracteriza-se como um estudo exploratório, descritivo, focalizando as BP's de higiene e armazenamento do estoque. 0 estudo foi desenvolvido em uma UAN, que produz refeições distribuídas, no desjejum, no almoço e lanches entre os horários da manhã e tarde. Localizada na Universidade Federal Rural do Rio de Janeiro - UFRRJ, no Campus Seropédica, RJ. 0 estudo foi realizado nos meses de setembro a novembro de 2014.

Os dados foram coletados mediante a aprovação prévia da responsável técnica da UAN. O levantamento dos dados foi realizado por observação direta e verificação documental, utilizando-se um check list, determinados pela Resolução RDC no 216, de 15 de setembro de 2004, da BRASIL (2004), que regulamenta as Boas Práticas para Serviços de Alimentação e a portaria no 2.914, de 12 de dezembro de 2011.

As questões abordadas no check list foram desenvolvidas apenas no que se refere ao estoque de alimentos sendo distribuídas em 6 itens de avaliação como: Higienização do estoque (Equipamentos, moveis e utensílios e controle integrado de vetores e pragas urbanas), Conservação (armazenamento da matérias primas, data de validade, temperatura, embalagens e equipamento) Ambiência (temperatura, ventilação, umidade e iluminação, sonorização e cor) e Localização (paredes portas e janelas, piso e área de aprovisionamento). Os critérios usados para avaliação dos itens foram conforme, não conforme e não se aplica.

A UAN em estudo se localiza na cidade de Seropédica Rio de Janeiro, Brasil na UFRRJ, a mesma oferece em média de 1280 refeições por dia, servidas para professores, agentes administrativos e alunos da instituição.

\section{RESULTADOS E DISCUSSÕES}

\subsection{DIAGNOSTICO INICIAL}

Constatou-se que o setor de alimentação tem uma coordenação administrada por uma Economista Doméstica e uma responsável pela merenda.

A aplicação do check list ocorreu no dia 10 de novembro de 2014 e teve duração de 2 horas. Abaixo está apresentando o resultado tabulado do check list aplicado (Tabela 1). 
Tabela 1. Resultado do check list.

\begin{tabular}{|c|c|c|c|c|c|c|c|}
\hline Item avaliado & $\begin{array}{c}\text { Itens } \\
\text { avaliados }\end{array}$ & $\mathrm{C}$ & $\mathrm{NC}$ & NA & $\begin{array}{c}\text { Itens } \\
\text { Conformes } \\
(\%)\end{array}$ & $\begin{array}{c}\text { Itens Não } \\
\text { Conforme } \\
(\%)\end{array}$ & $\begin{array}{c}\text { Itens Não } \\
\text { se Aplica } \\
(\%)\end{array}$ \\
\hline $\begin{array}{l}\text { Instalações e } \\
\text { edificações }\end{array}$ & 12 & 5 & 4 & 3 & 42 & 33 & 25 \\
\hline $\begin{array}{l}\text { Higiene das dos } \\
\text { equipamentos }\end{array}$ & 7 & 4 & 3 & 0 & 57 & 43 & \\
\hline $\begin{array}{l}\text { Controle de } \\
\text { armazenamento }\end{array}$ & 6 & 2 & 4 & 0 & 33 & 67 & \\
\hline $\begin{array}{l}\text { Controle de } \\
\text { pragas e vetores }\end{array}$ & 1 & 0 & 0 & 1 & & & 100 \\
\hline Conservação & 2 & 0 & 2 & 0 & & 100 & \\
\hline Ambiência & 2 & 0 & 2 & 0 & & 100 & \\
\hline Total de Itens & \multicolumn{7}{|c|}{30} \\
\hline
\end{tabular}

Os resultados revelaram muitas não conformidades 50\% e índices de conformidade 36,66 \% e não se aplica de 13,33\%. Quanto à avaliação das condições higiênico-sanitárias do estoque verificou se a partir da aplicação do check-list, a quantidade de itens conformes (11), não conforme (15) e não se aplica (4) a unidade de alimentação e nutrição, de acordo com as boas práticas higiênico-sanitárias.

\subsection{EDIFICAÇõES E INSTALAÇõES}

Através da aplicação do check list verificou se que a localização da unidade de alimentação e térrea na qual proporciona fácil acesso externo para abastecimento, porém foi observado que o estoque fica fora da cozinha, possibilitando ocasionar, através de chuvas e temperaturas baixas doenças como gripe, resfriado ao colaborador. 0 estoque não apresenta iluminação natural e condições de ventilação, de acordo com a legislação o piso encontra se dentro da conformidade sendo de material adequado, antiderrapante, liso, lavável, encontrando-se em bom estado de conservação, quanto as paredes estão não conformes, pois são pintadas com tinta epóxi de cor branca e lavável sendo que com o tempo a tinta resseca e começa a soltar das paredes podendo contaminar os alimentos, segundo a legislação as paredes devem ser revestidas de azulejo. Quanto às portas verificou-se que o estoque apresenta uma única porta, entrada e saída dos alimentos, sendo assim, pode-se dizer que há um fluxo cruzado de entrada e saída dos alimentos.

De acordo com a legislação ANVISA (2004), as portas devem ser mantidas ajustadas aos batentes. As portas do armazenamento de alimentos devem ser dotadas de fechamento automático, o resultado revelou que a porta é de ferro de superfície lisa e não absorvente encontrando-se em bom estado de conservação e ajustada ao batente encontrando-se conforme. Também foi observado que o estoque não apresenta nas suas edificações janelas, encontrando-se não se aplica.

Quanto à ventilação não se aplica, verificou se que não há janelas, tornando o local muito quente e sem ventilação, A ventilação, a temperatura e a umidade estão implicitamente interligadas. Segundo Teixeira et al. (2004), a ventilação deve ser adequada para propiciar a renovação do ar, garantindo o conforto térmico. A circulação do ar deve ser assegurada por meios naturais ou por equipamentos devidamente direcionados. Também foi verificado que as luminárias encontram-se em não se aplica na Figura 2 (A), pois não possuem sistema de proteção, podendo ocasionar acidentes, pois devem ser apropriadas e estar protegidas contra explosão e quedas acidentais conforme a legislação.

Os ralos de acordo com a legislação devem ter abertura ou superfície ampla e com grade de metal, em posição e local que facilite o escoamento, conforme Figura 2 (B) os ralos estão dentro da não conformidade apresentam grelhas, porém encontram se quebradas podendo ocasionar acidentes. 
Figura 2. Iluminação (A) e ralos com grelhas quebradas (B)

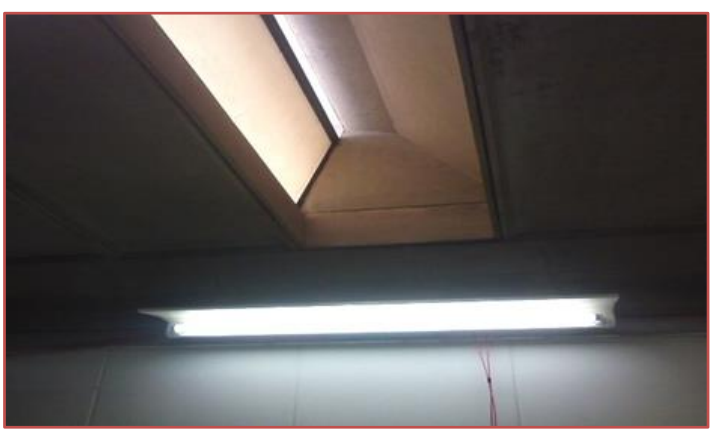

(a)

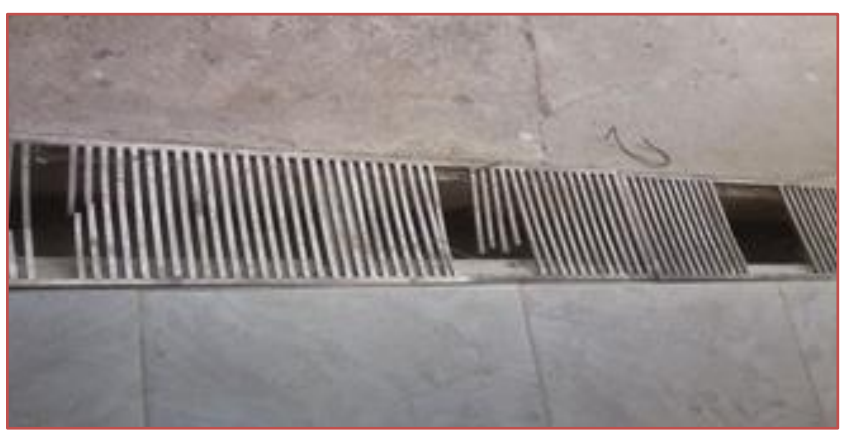

(b)

\subsection{EQUIPAMENTOS}

Quanto ao o armazenamento com temperatura controlada observou-se que o local não dispõe de câmaras frigoríficas e sim de freezers e geladeiras. Os resultados revelaram que a temperatura da refrigeração $\left(6{ }^{\circ} \mathrm{C}\right)$ e a temperatura de congelamento (acima de $18{ }^{\circ} \mathrm{C}$ ) estão dentro da conformidade (Figura 3). Entretanto os freezers foram encontrados com muito gelo e sujos, também foi observado a temperatura dos mesmos apresentando temperaturas com -24 e $-30^{\circ} \mathrm{C}$, encontrado temperaturas mais baixas do que $\mathrm{o}$ recomendado $\left(-18^{\circ} \mathrm{C}\right)$. Sendo assim o congelamento está sendo feito de forma correta, deixando o alimento livre de crescimento de microrganismos. Como também tem uma área de resfriamento apresentando uma temperatura de $5,3^{\circ} \mathrm{C}$ onde se encontra dentro da conformidade.

Quanto à limpeza dos equipamentos, foi observado que os freezers encontravam-se sujos e também que os alimentos estavam estocados em caixas de papelão conforme são entregues pela fornecedora.

Figura 3. Condições higiênicas (A) e de armazenamento do freezer (B)
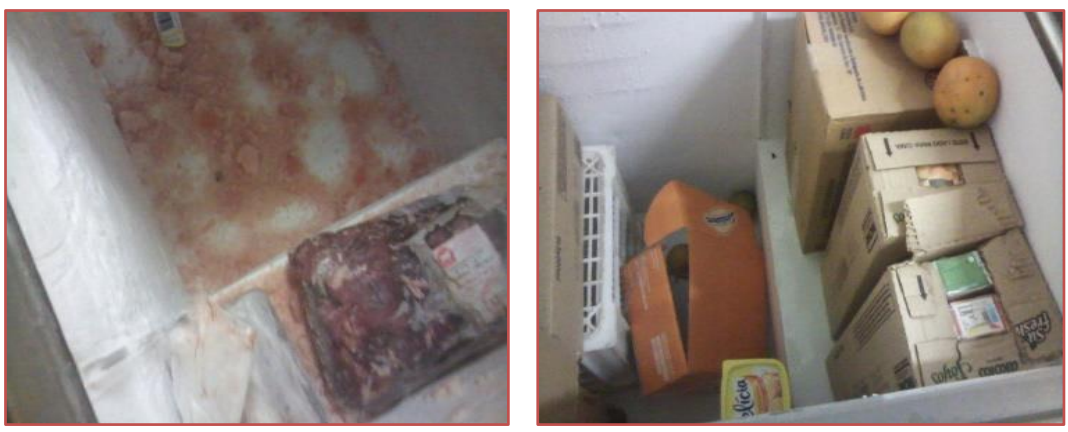

\subsection{CONDIÇÕES DE ARMAZENAMENTO}

Quanto ao armazenamento dos alimentos secos, foi encontrado grãos de arroz espalhados pelo chão e alimentos abertos, esse tipo de sujidade pode ocasionar a entrada de pragas e roedores no local.

A organização do armazenamento dos alimentos secos revelou muitas não conformidades. Foi encontrado caixas de papelão espalhadas pelo chão, estrados de madeira, prateleiras de material inadequado (como ferro), encontrando-se em estado de conservação regular. Os alimentos são estocados inadequadamente, pois estão encostados na parede não recebendo ventilação nem circulação (Figura 4). 
Figura 4. Armazenamento dos alimentos (A) e (B)
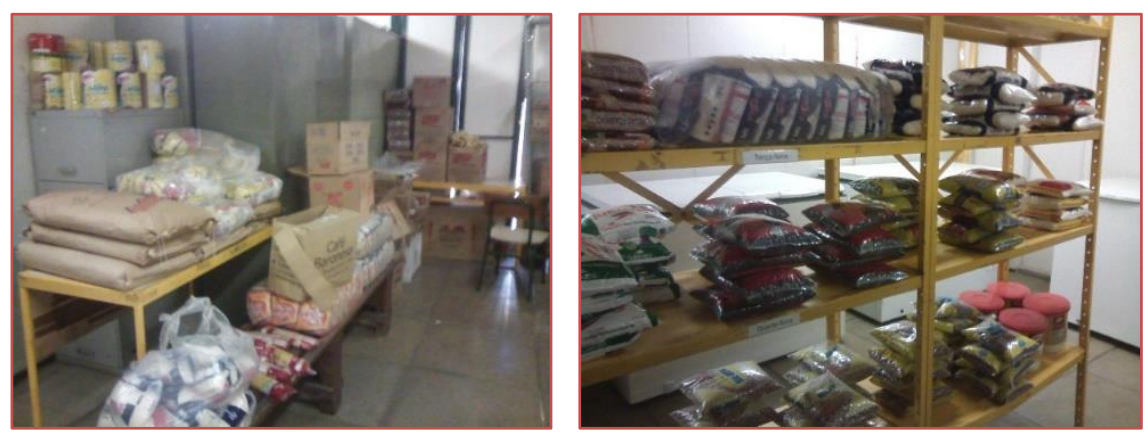

\subsection{CONSERVAÇÃO}

Foi observado quanto à data de validade do alimento que havia no estoque alimentos com data vencida, de acordo com a ANVISA (2002a), o prazo de validade relaciona-se ao período de tempo no qual o produto ainda possui qualidade adequada para o consumo. Esta qualidade pode ser definida em função de vários aspectos, como sensoriais (cor, textura, suculência, etc), tecnológicos ( $\mathrm{pH}$, capacidade de retenção de água, etc), nutricionais (quantidade de gordura, perfil dos ácidos graxos, grau de oxidação, etc), sanitários (ausência de agentes contagiosos), ausência de resíduos físicos (antibióticos, hormônios, etc), dentre outros. A RDC n ${ }^{\circ} 259$, de 20 de setembro de 2002, estabelece que o prazo de validade seja uma informação obrigatória na rotulagem de alimentos, buscando assim garantir o consumo de alimentos de qualidade ainda adequada (ANVISA, 2002a).

É a metodologia mais comum utilizada principalmente em indústrias e distribuidores de produtos sem datas de validade. Por exemplo: plásticos injetados, papel e produtos de aço inoxidável. Nesta metodologia, tendo em vista que os produtos têm prazo de validade indeterminado, considera-se a entrada dos lotes de produtos para uso em ordem de chegada. Produtos que entraram primeiro no estoque são utilizados primeiro, o que garante que sempre haverá produtos novos para uso.

Uma das formas de uso do PEPS (Primeiro que Entra, Primeiro que Sai), pode ser o uso de etiquetas que indiquem as datas de entrada de produtos, ou até mesmo um controle físico, onde o produto mais antigo é disposto à frente, e o mais recente é colocado atrás, para garantia de uso na ordem correta: primeiro os mais antigos, depois os mais novos.

\subsection{CONTROLE DE ROEDORES E PRAGAS URBANAS}

Quanto ao controle de roedores e pragas urbanas não foram identificados sinais de roedores e pragas durante o estágio, porém foi questionado sobre a documentação de controle de pragas sendo que não obtendo resposta pela responsável.

Os POPs relacionados ao controle integrado de vetores e pragas urbanas devem contemplar as medidas preventivas e corretivas destinadas a impedir a atração, o abrigo, o acesso e ou a proliferação de vetores e pragas urbanas. No caso da adoção de controle químico, o estabelecimento deve apresentar comprovante de execução de serviço fornecido pela empresa especializada contratada, contendo as informações estabelecidas em legislação sanitária específica. (ANVISA, 2004).

O estoque é parte essencial de qualquer empresa que realize a fabricação e/ou a distribuição de produtos. Itens de algumas das principais normas que regem os sistemas de gestão dedicam, muitas vezes, apenas algumas linhas para mencionar esta importante parte das organizações, sem muitas vezes considerar práticas aprofundadas orientadas ao controle destes estoques (BEZERRA, 2013). De acordo com a Resolução - RDC № 275, de 21 de outubro de 2002 dispõe sobre o Regulamento Técnico de Procedimentos Operacionais Padronizados aplicados aos Estabelecimentos Produtores/Industrializadores de Alimentos e a Lista de Verificação das Boas Práticas de Fabricação em Estabelecimentos Produtores/Industrializadores de Alimentos (ANVISA, 2002b). Durante o período de estágio de acordo com o resultado do check list foi dado instruções ao técnico responsável como organizar o estoque seco como o de temperatura controlada. 


\section{RECOMENDAÇõES}

Como sugestão foi recomendado a coordenação: o uso de ventiladores de teto para melhorar a ventilação e circulação do ar, os freezers estejam limpos uma vez a cada 15 dias, os alimentos estejam armazenados fora de caixas de papelão, os alimentos estejam organizados de acordo com os PEPS, a limpeza seja feita diariamente, que haja um controle de vetores e pragas urbanas e treinamento para os colaboradores.

\section{REFERÊNCIAS}

[1] ABERC - ASSOCIAÇÃO BRASILEIRA DAS EMPRESAS DE REFEIÇÕES COLETIVAS. Unidade de Alimentação e Nutrição condições estruturais: edifícios e instalações. In: (Ed.). Manual prático de elaboração e serviço de refeições para coletividade. 8 ed. São Paulo, 2008.

[2] BEZERRA, G. Qualidade na pratica PEPS - PVPS e a qualidade integrada no estoque. 2013. Disponível em: < http://certificacaoiso.com.br/qualidade-na-pratica-peps-e-pvps-e-a-qualidade-integrada-ao-estoque/ >. Acesso em: 04/06/2016.

[3] BRASIL, ANVISA - Agência Nacional de Vigilância Sanitária. Resolução RDC no 259, de 20 de setembro de 2002a.

[4] BRASIL, ANVISA - Agência Nacional de Vigilância Sanitária. Resolução RDC no 275, de 21 de outubro de 2002 2002b.

[5] BRASIL, ANVISA - Agência Nacional de Vigilância Sanitária. Resolução - RDC no 216 de 15 de setembro de 2004. Dispõe sobre as boas práticas para serviço de alimentação. Diário Oficial da República Federativa do Brasil. Brasília 2004.

[6] CODEX ALIMENTARIUS. Higiene dos alimentos - textos básicos. Adaptação: Organização Pan- Americana Da Saúde (OPAS), Organização Mundial da Saúde (PMS) Agencia Nacional de Vigilância Sanitária (ANVISA), 2006.

[7] HEBA. 2015. Disponível em: < www.heba.com.br >. Acesso em: 09/09/2015.

[8] MANZALLI, P. V. Manual para Serviços de Alimentação: implementação, boas práticas, qualidade e saúde. 2ํㅗㅇ edição "revista e ampliada". Editora Metha Ltda. São Paulo. 2010.

[9] MENEGAZZO, M. et al. Avaliação qualitativa das preparações do cardápio de centros de educação infantil. Rev. nutr, v. 24, n. 2, p. 243-251, 2011.

[10] OLIVEIRA, N. F. W.; NERY, M. Administração em serviços de nutrição. Rio de Janeiro. Editora Cultura médica, 1986.

[11] PORTARIA CVS-6. Aprovar o presente "Regulamento Técnico, que estabelece os Parâmetros e Critérios para o Controle Higiênico-Sanitário em Estabelecimentos de Alimentos". 1999. Disponível em: < http://www.cvs.saude.sp.gov.br/zip/E_PT-CVS-06_100399.pdf >. Acesso em: 09/09/2015.

[12] RIBEIRO, C. D. S. G. Análise de Perdas em Unidades de Alimentação e Nutrição (UANs) industriais: estudo de caso em Restaurantes Industriais. Dissertação de mestrado, Universidade Federal de Santa Catarina, 2002.

[13] RICARTE, M. P. R. et al. Avaliação do desperdício de alimentos em uma unidade de alimentação e nutrição institucional em Fortaleza-CE. Saber científico, v. 1, n. 1, p. 159-175, 2008.

[14] ROSSI, C. F. Condições higiênico-sanitárias de restaurantes comerciais do tipo self-service de Belo HorizonteMG. 142 p. Dissertação (Mestrado em Ciência de Alimentos). Universidade Federal de Minas Gerais, Belo Horizonte. 2006.

[15] SILVA JUNIOR, E. A. D. Manual de controle higiênico-sanitário em alimentos. São Paulo: Varela: 2001.

[16] TEIXEIRA, S. M. F. et al. Administraçäo aplicada às unidades de alimentaçäo e nutriçäo. São Paulo: Atheneu: 2004 .

[17] ZANELLA, L. C.; CANDIDO, Í. Restaurante: técnicas e processos de administração e operação. Caxias do Sul: EDUCS, p. 13, 2002. 


\section{Capítulo 21}

Nível de segurança de fórmulas infantis preparadas no Lactário de um hospital universitário do Estado do Rio de Janeiro

\section{Deborah Rodrigues Siqueira \\ Silvia Magalhães Couto Garcia \\ Maria Lúcia Mendes Lopes \\ Carolina Pinto de Carvalho Martins \\ Carolina Cataldo}

Resumo: 0 objetivo deste estudo foi verificar o nível de segurança das fórmulas infantis preparadas no lactário de um Hospital Universitário do Estado do Rio de Janeiro, por meio da aplicação do Índice de Segurança (IS) na análise das temperaturas da água de reconstituição das fórmulas em pó e da geladeira de conservação das fórmulas reconstituídas. Para análise do nível de segurança das fórmulas infantis, foi calculado o IS, considerando como meta os parâmetros de temperaturas propostos pelas legislações específicas. As temperaturas médias da água nos turnos manhã e tarde foram respectivamente, $8^{\circ}{ }^{\circ} \mathrm{C}$ e $91,5^{\circ} \mathrm{C}$ e o IS foi de 0,98 . As temperaturas médias da geladeira foram $2,5^{\circ} \mathrm{C}$ e $3,1^{\circ} \mathrm{C}$ e IS de 0,99 . 0 IS obtido revelou grau satisfatório de cumprimento das exigências da legislação vigente. 0 monitoramento destas etapas é fundamental para garantia da qualidade das fórmulas produzidas.

Palavras-chave: fórmula infantil, controle de qualidade, temperatura, índice de segurança. 


\section{INTRODUÇÃO}

As doenças transmitidas por alimentos (DTA) são consideradas um eminente problema de saúde pública e são causadas por ingestão de alimento ou água contaminada. No Brasil, no período de 2000 a 2014, houve 9.719 surtos de DTA, sendo identificados a água, leite e derivados como tendo, respectivamente, 563 e 356 casos nesse período. Dentre os locais de ocorrência de surtos de DTA, os hospitais e unidades de saúde representam 2,5\% (Sinan, 2014). Por diversos fatores, muitos casos de DTA, não são notificados, inviabilizando identificar a gravidade do problema.

Neste contexto, as unidades hospitalares responsáveis pela produção de alimentos merecem atenção especial. Entre aquelas identificadas como sendo de risco, encontra-se o lactário, uma área restrita e exclusiva destinada ao preparo, higienização e distribuição de fórmulas infantis e complementares, para alimentação de recém-nascidos e de pacientes pediátricos (Santos e Tondo, 2000). Os neonatos de baixo peso ao nascer e a permanência em unidades de cuidados intensivos neonatais os tornam mais vulneráveis a desencadear DTA, principalmente pela imaturidade do sistema intestinal e imunológico (Mardaneh e Soltan-Dallal, 2014).

0 aleitamento materno exclusivo deve ser encorajado até 6 meses de vida, no entanto, algumas situações clinicas contraindicam essa prática. Nesses casos as fórmulas infantis são indicadas em substituição total ou parcial do leite humano para crianças em risco nutricional, com a finalidade de atender suas necessidades nutricionais (Brasil, 2012).

As fórmulas infantis em pó não são estéreis e durante sua reconstituição podem ser contaminadas por várias espécies de bactérias. Dentre elas, a Cronobacter spp. é uma das espécies mais prejudiciais, uma vez que pode causar sepse, meningite e enterocolite ulcerativa em recém-nascidos prematuros (Silano et al., 2016).

A adoção de Boas Práticas, como o preparo e armazenamento das fórmulas infantis de forma correta podem reduzir os riscos de contaminação microbiana e minimizar a incidência de surtos de DTA.

A reconstituição das fórmulas infantis em pó deve ser feita com água fervida e resfriada à temperatura superior a $70^{\circ} \mathrm{C}$ (Who/Fao, 2007; Brasil, 2011). As fórmulas infantis reconstituídas podem ser armazenadas por, no máximo, $24 \mathrm{~h}$ em geladeira exclusiva com temperatura entre 2 e $8^{\circ} \mathrm{C}$ (Brasil, 2000). 0 monitoramento das temperaturas nestas etapas possibilita também avaliar os processos e aplicar de forma imediata as ações corretivas necessárias (Renno, 2013).

O objetivo deste estudo foi identificar o nível de segurança das fórmulas infantis preparadas no lactário de um Hospital Universitário do Estado do Rio de Janeiro, por meio da utilização do Índice de Segurança (IS) na análise das temperaturas da água de reconstituição das fórmulas infantis em pó e das temperaturas da geladeira de armazenamento das fórmulas reconstituídas.

\section{MATERIAIS E MÉTODOS}

Tratou-se de um estudo descritivo, com delineamento transversal, realizado no lactário de um Hospital Universitário do Estado do Rio de Janeiro, no período de setembro de 2015 a março de 2016.

As temperaturas da água de reconstituição de fórmulas em pó e da geladeira de armazenamento das fórmulas reconstituídas foram aferidas diariamente em dois momentos, pela manhã e à tarde, antes de cada etapa de preparo. Para reconstituição das fórmulas em pó, foi utilizada a água do filtro proveniente da rede de abastecimento público, previamente fervida. A geladeira utilizada para armazenamento das fórmulas reconstituídas é exclusiva para este fim.

Para aferir a temperatura da água de reconstituição utilizou-se termômetro digital do tipo espeto com escala de $-50^{\circ} \mathrm{C}$ a $300^{\circ} \mathrm{C}$ e para aferir a temperatura da geladeira o termômetro digital interno/externo com escala de $-20^{\circ} \mathrm{C}$ a $70^{\circ} \mathrm{C}$, ambos calibrados e higienizados com álcool $70 \%$. Os dados foram registrados em formulários próprios e monitorados pela nutricionista do setor.

O nível de segurança higiênico-sanitária das fórmulas infantis foi determinado por meio do Índice de Segurança (IS), proposto por Kawasaki et al (2007). O IS é representado pela relação entre o número de aferições de temperaturas que atenderam à legislação vigente e o total de aferições realizadas no período do estudo. Este índice pode variar de 0 a 1,0 e os valores mais próximos de 1,0 representam maior grau de segurança higiênico-sanitária do alimento. 
Os dados foram expressos em média e desvio padrão, considerando duas aferições diárias. A média foi comparada com os respectivos parâmetros estabelecidos pelas legislações vigentes. Para comparar as médias de temperaturas entre os dois turnos, foi utilizado teste $t$, adotando $p \leq 0.05$ como nível de significância. Foi calculado IS para cada etapa do processo estudado.

\section{RESULTADOS E DISCUSSÃO}

Em relação as temperaturas da água de reconstituição, identificou-se que 98,1\% apresentaram valores acima de $70^{\circ} \mathrm{C}$ (Brasil, 2011). Dentre as temperaturas da geladeira de armazenamento de fórmulas reconstituídas, 99\% apresentaram valores entre $2^{\circ} \mathrm{C}$ e 8ํㅡ (Brasil, 2000).

A Tabela 1 demonstra a média e desvio-padrão das temperaturas da água de reconstituição de fórmulas infantis em pó estratificados por mês e por turno. Considerando o grau de variação em relação à média, observou-se que, no mês de setembro, no turno da manhã, a temperatura média da água foi inferior a $70^{\circ} \mathrm{C}$. Nos demais meses e turnos analisados, as temperaturas médias da água estavam em conformidade com a legislação vigente.

As temperaturas médias no período analisado para os turnos manhã e tarde foram respectivamente, $89^{\circ} \mathrm{C}$ e 91,5ํㅡ. Com exceção do mês de novembro, todas as temperaturas médias aferidas no turno da tarde apresentaram-se mais elevadas quando comparadas com as temperaturas do turno da manhã

Verificou-se diferença significativa entre as médias das temperaturas nos turnos da manhã e da tarde, no mês de dezembro $(\mathrm{p}=0,05)$. Nos demais meses, apesar das temperaturas apresentarem diferenças entre os turnos, essas não foram estatisticamente significativas.

Tabela 1. Temperaturas médias, desvio padrão, valor de p da água de reconstituição das fórmulas infantis em pó, no período de setembro de 2015 a março de 2016.

\begin{tabular}{|l|c|c|c|}
\multicolumn{1}{c}{ Meses } & \multicolumn{2}{c}{$\begin{array}{c}\text { Temperatura média }\left({ }^{\circ} \mathrm{C}\right) \\
\text { Desvio padrão/ turno } \\
\text { Manhã }\end{array}$} & $\begin{array}{c}\text { Tarde } \\
\text { Setembro }\end{array}$ \\
\hline Outubro & $78,8 \pm 17,5$ & $87,6 \pm 15,4$ & 0,06 \\
\hline Novembro & $87,8 \pm 10,6$ & $91,7 \pm 8,4$ & 0,08 \\
\hline Dezembro & $94,3 \pm 9,2$ & $93,4 \pm 8,9$ & 0,64 \\
\hline Janeiro & $90,9 \pm 9,9$ & $94,9 \pm 7,2$ & $0,05^{*}$ \\
\hline Fevereiro & $90,6 \pm 9,0$ & $90,7 \pm 8,8$ & 0,96 \\
\hline Março & $88,3 \pm 8,7$ & $89,4 \pm 10,3$ & 0,60 \\
\hline Média ${ }^{\circ}$ C/ turno & $92,0 \pm 9,1$ & $93,1 \pm 8,9$ & 0,60 \\
\hline
\end{tabular}

A Tabela 2 apresenta a média e desvio-padrão das temperaturas da geladeira de armazenamento de fórmulas infantis reconstituídas por mês e por turno. Considerando esses valores, verificou-se que, no mês de setembro, no turno da tarde, a temperatura média da geladeira foi superior a 8으, caracterizando inconformidade com a RDC n63 (Brasil, 2000). Nos demais meses e turnos analisados, as temperaturas médias da água estavam em conformidade com a legislação vigente.

As temperaturas médias da geladeira para os turnos manhã e tarde foram respectivamente, $2,5^{\circ} \mathrm{C}$ e $3,1^{\circ} \mathrm{C}$. Observou-se diferença significativa entre as médias das temperaturas nos turnos da manhã e da tarde, no mês de setembro $(\mathrm{p}=0)$. Essas oscilações significativas nas temperaturas da geladeira, podem indicar a necessidade de avaliar a manutenção do equipamento, assim como, observar a frequência de abertura da porta da geladeira. Nos demais meses, não houve diferença estatisticamente significativa. 
Tabela 2. Temperaturas médias, desvio padrão e valor de p da geladeira de armazenamento de fórmulas infantis reconstituídas, no período de setembro de 2015 a março de 2016.

\begin{tabular}{|c|c|c|c|}
\hline \multirow[t]{2}{*}{ Meses } & \multicolumn{2}{|c|}{$\begin{array}{l}\text { Temperatura média }\left({ }^{\circ} \mathrm{C}\right) \\
\text { Desvio padrão/ turno }\end{array}$} & \multirow[t]{2}{*}{ P valoı } \\
\hline & Manhã & Tarde & \\
\hline Setembro & $3,1 \pm 1,3$ & $6,5 \pm 1,7$ & $0 *$ \\
\hline Outubro & $2,7 \pm 1,8$ & $3,3 \pm 2,3$ & 0,12 \\
\hline Novembro & $3,1 \pm 2,1$ & $3,1 \pm 1,8$ & 0,95 \\
\hline Dezembro & $2,3 \pm 1,7$ & $2,1 \pm 1,3$ & 0,61 \\
\hline Janeiro & $2,0 \pm 1,2$ & $1,7 \pm 1,4$ & 0,50 \\
\hline Fevereiro & $2,8 \pm 1,4$ & $2,5 \pm 1,3$ & 0,48 \\
\hline Março & $1,8 \pm 1,2$ & $2,0 \pm 1,5$ & 0,55 \\
\hline Média ${ }^{\circ} \mathrm{C} /$ turno & 2,5 & 3,1 & \\
\hline
\end{tabular}

Os IS para as temperaturas da água de reconstituição e para as temperaturas da geladeira foram respectivamente, 0,98 e 0,99 (tabela 3). Para cálculo do IS, foram consideradas as aferições que atenderam as legislações, como sendo aquelas cujas temperaturas da água estavam acima de $70^{\circ} \mathrm{C}$ e as temperaturas da geladeira abaixo de 8ㅜㅡ (Brasil, 2011; Brasil, 2000).

De acordo com este método de análise de qualidade sanitária, os índices mais próximos de 1,0, expressam menor risco sanitário. Sendo assim, os resultados evidenciam que, nestas etapas, o grau de segurança higiênico-sanitária foi alto, demostrando controle de qualidade eficaz e monitoramento adequado nas etapas de processo estudadas.

Um estudo realizado na França, por Rosset et al (2007) avaliou as condições de temperatura no preparo e armazenamento de fórmulas infantis em pó para crianças internadas em unidades de cuidados neonatais e associou o impacto destes resultados com o crescimento potencial da Enterobacter spp. Os autores concluíram que, o incremento no crescimento bacteriano foi o resultado da combinação de diferentes parâmetros, como: temperatura inicial da fórmula infantil, temperatura do ambiente de manipulação, temperatura do armazenamento à frio e temperatura e tempo do reaquecimento das fórmulas (Rosset et al, 2007).

Tabela 3. IS das etapas de processo estudadas no período de setembro de 2015 a março de 2016.

\begin{tabular}{|l|c|c|c|}
\hline \multicolumn{1}{|c|}{ Etapa } & NMM & NTM & IS \\
\hline Temperatura da água de reconstituição de fórmulas em pó & 404 & 412 & 0,98 \\
\hline Temperatura da geladeira de armazenamento de fórmulas reconstituídas & 408 & 412 & 0,99 \\
\hline
\end{tabular}

NMM: Número de aferições que atenderam a legislação NTM: Número total de aferições IS: índice de Segurança

\section{CONCLUSÃO}

Os índices de segurança das temperaturas da água de reconstituição das fórmulas infantis em pó e da geladeira de armazenamento de fórmulas reconstituídas foram próximos de 1,0, revelando grau satisfatório no cumprimento das metas propostas pelas legislações vigentes e bom nível de segurança no controle higiênico-sanitário das fórmulas infantis nas etapas estudadas.

O uso de indicadores como o IS, associados a implantação de programas de Gestão da Qualidade, é útil na análise dos dados coletados no monitoramento das etapas de processo. Eles permitem identificar falhas no processo, etapas críticas e priorizar ações corretivas, minimizando os riscos de contaminação. 


\section{REFERÊNCIAS}

[1] Brasil. Agencia Nacional de Vigilância Sanitária. (2000). Resolução da Diretoria Colegiada $n^{\circ} 63.6$ de julho de 2000. Regulamento técnico: Requisitos Mínimos exigidos para a Terapia de Nutrição Enteral. Ministério da saúde. Brasília/DF.

[2] Brasil. Agência Nacional de Vigilância Sanitária. (2011).Resolução da Diretoria Colegiada no 45 , de 19 de setembro de 2011. Regulamento Técnico para fórmulas infantis para lactentes destinadas a necessidades dietoterápicas específicas e fórmulas infantis de seguimento para lactentes e crianças de primeira infância. Diário Oficial da União. Brasília/DF.

[3] Kawasaki, V.M., Cyrillo, D.C.\& Machado, F.M.S. (2007). Custo-efetividade da produção de refeições coletivas sob o aspecto higiênico-sanitário em sistemas cook-chill e tradicional. Rev Nutr. 20(2):129-38.

[4] Mardaneh, J. \& Soltan-Dallal, M. M. (2014). Isolation and Identification of E. cowanii from Powdered Infant Formula in NICU and Determination of Antimicrobial Susceptibility of Isolates.Iran J Pediatr, v. 24, n. 3, p. 261-266.

[5] Rennó, F.F., Weber, M.L.\& Gonçalves, E.S. (2013). Análise do nível de segurança das refeições produzidas em complexo hoteleiro de grande porte na região centro-oeste do Brasil. J Health Sci Inst.31(3):296-300.

[6] Rosset, P., Noel, V. \& Morelli, E. (2007). Time-temperature profiles of infant milk formula in hospital sand analysis of Enterobacter sakazakii growth. Food Control. 18, 1412-1418.

[7] Santos, M.I.S. \& Tondo, E.C. (2000). Determinação dos perigos e pontos críticos de controle para implantação de sistema APPCC. Rev. Nutr. Campinas, v.13, n.3, p. 211-222.

[8] Silano, M., Paganin, P.\& Davanzo, R. (2016). Time for the $70^{\circ} \mathrm{C}$ water precautionary option in the home dilution of powdered infant formula. Italian Journal of Pediatrics, 42:17.

[9] Ministério da Saúde (2014).Sistema de Informação de Agravos de Notificação (SINAN net).Secretaria de Vigilância em Saúde, Departamento de Vigilância Epidemiológica, Coordenação Geral de Vigilância das Doenças Transmissíveis. Brasília.

[10] Who/Fao. (2007).How to Prepare Formula for Bottle-Feedingat Home. Geneva: Who. 


\section{Capítulo 22}

Avaliação do conhecimento e atuação de manipuladores de alimentos em redes de escolas estaduais do Município de Três Passos/RS

\section{Luciana de Abreu}

Fernanda Hart Weber

Mastrangello Enivar Lanzanova

Glaciela Cristina Rodrigues da Silva Scherer

Hardi Germano Weirich

Resumo: Doenças transmitidas por alimentos contaminados comprometem a saúde de crianças que frequentam e recebem a merenda nas escolas estaduais do RS. Este trabalho teve como objetivo avaliar o conhecimento dos manipuladores das escolas estaduais do município de Três Passos, RS, em relação a segurança dos alimentos. 0 estudo foi realizado de agosto a dezembro de 2014, e constou da aplicação de um questionário as merendeiras, contendo 25 perguntas referentes ao tema da alimentação. Os questionários apontaram necessidade de aprofundamento nos estudos e conhecimentos sobre a conservação e a maneira correta de manipulação dos alimentos. Verificou-se que a situação é preocupante, e se não haver adequação a legislação, intoxicações alimentares poderão fazer parte do cotidiano. 


\section{INTRODUÇÃO}

A escola exerce um importante papel no desenvolvimento e manutenção de hábitos alimentares, visto que é nesse ambiente que significativa proporção de crianças e adolescentes permanecem por expressivo período de tempo diário. A segurança dos alimentos é um tema que vem despertando interesse do poder público nos últimos anos, de maneira especial em função da contaminação potencial que o consumo de alimentos sem qualidade ou contaminado pode provocar na saúde da população e, no caso das escolas, na saúde das crianças, jovens e adultos. Com a necessidade de assegurar que diversos procedimentos fossem adotados a fim de diminuir falhas, foram elaboradas legislações através da Agência Nacional de Vigilância Sanitária/ANVISA, como por exemplo a Resolução - RDC 216/2004.

De acordo com dados do Ministério da Saúde, no ano de 2012 foram notificados 792 surtos no Brasil acarretando 20.000 doentes, sendo os estados da região sul e sudeste as que possuem os maiores números de notificações. 0 desenvolvimento de alimentos seguros é prática necessária, em particular nas escolas públicas, espaço que atende uma clientela vulnerável quanto aos aspectos nutricional e socioeconômico, e para a qual, em muitos casos, esse alimento compõe a única refeição do dia. Portanto, a ocorrência de um surto de DTA nesse ambiente tende a configurar-se como um problema de saúde pública (BRASIL, 2014).

Devido a magnitude dos dados acima referidos, o objetivo deste trabalho foi avaliar o grau ou nível de conhecimento das merendeiras das escolas estaduais do município de Três Passos, com relação a conceitos de higiene de alimentos, conhecimento higiênico-sanitário e práticas adotadas durante a manipulação e preparo dos alimentos.

\section{METODOLOGIA}

O presente trabalho é considerado um estudo de caso, e foi realizado no segundo semestre de 2014, através da aplicação de questionários ao público alvo da pesquisa, que foram as merendeiras das escolas estaduais do município de Três Passos, RS. As perguntas foram elaboradas em conjunto entre três professores com pós graduação na área de ciência e tecnologia dos alimentos. Os questionários foram aplicados de forma escrita, onde cada merendeira assinalou as respostas, ou as escreveu na própria folha de questões. No total foram pesquisadas 05 escolas, com aplicação de 16 questionários (16 merendeiras). 0 questionário foi composto por 25 perguntas, com respostas objetivas, exceto a verificação do nível de escolaridade das merendeiras. Com relação ao total de perguntas realizadas, 3 foram selecionadas para maior discussão e detalhamento. Os dados foram analisados de maneira quantitativa, através da distribuição da frequência das respostas, utilizando o programa computacional Microsoft Excel@.

\section{RESULTADOS E DISCUSSÃO}

Na Figura 1 apresenta-se o resultado sobre a pergunta onde o reaquecimento dos alimentos é apresentado. Nota-se aqui uma clara desinformação das merendeiras sobre o assunto, visto que aproximadamente $1 / 3(31 \%)$ confirmaram não saber se o ato de reaquecer alimentos pode contribuir para uma possível contaminação alimentar. 
Figura 1. Resultado do questionamento: "Reaquecimento de alimentos contribui para possíveis contaminações alimentares?".

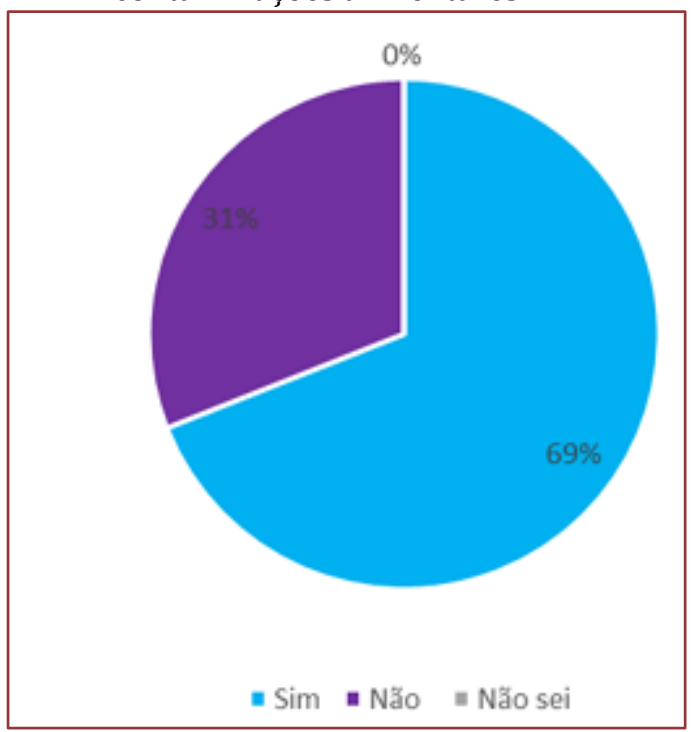

Segundo BRASIL (2014), quando um alimento que já foi preparado e é reaquecido, ocorre uma potencialização da proliferação de microrganismos patogênicos em função de estar se promovendo condições de temperatura adequadas para estes, e normalmente os alimentos possuem determinado teor de umidade, ou potencial de água, favorável a sua multiplicação, o que pode gerar a contaminação e intoxicação alimentar posteriormente. Observou-se durante a vistoria realizada nas cozinhas que todas possuem forno micro-ondas, o que facilita e torna prático o ato de esquentar e re-aquecer refeições para serem oferecidas aos alunos.

Na Figura 2 está apresentado o resultado da pergunta sobre os conceitos de sanitizar e limpar. Segundo a Resolução 238/1999 (BRASIL, 1999) sanitização corresponde ao conjunto de procedimentos usados na indústria de produtos alimentares e que visam à manutenção das condições de higiene indispensáveis à obtenção de materiais de primeira qualidade. Por outro lado, o conceito de limpeza significa é a eliminação de terra, restos de alimentos, pó e outras matérias indesejáveis (BRASIL, 1997).

Figura 2. Resultado do questionamento: "Você entende a diferença entre os conceitos de limpar e sanitizar?".

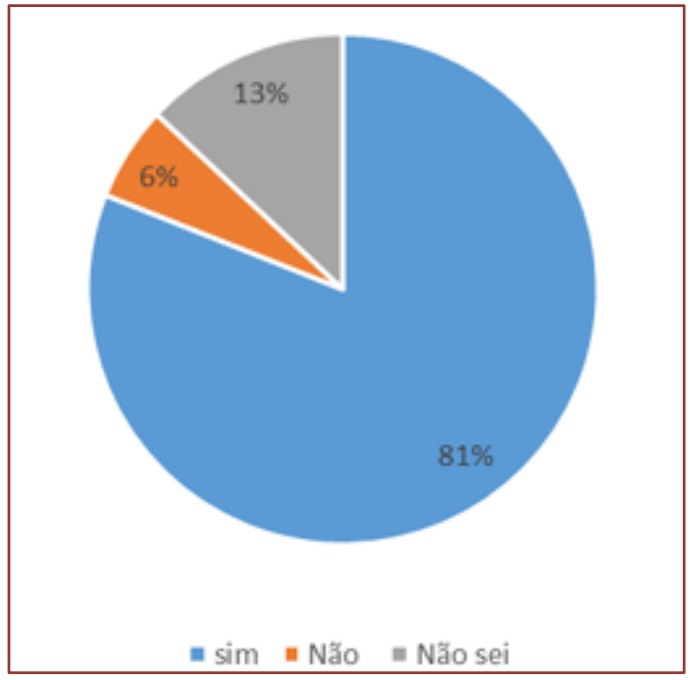


A teoria muitas vezes é ignorada pelas pessoas que trabalham com alimentos, e este resultado, ou seja, 19\% das merendeiras dizem não conhecer ou acreditar não haver diferença entre limpar e sanitizar. Tal constatação é motivo de preocupação para as escolas, indicando haver necessidade de reforçar o estudo e a cobrança sobre conhecimentos teóricos relacionados as boas práticas de fabricação. E também, a necessidade de acompanhamento diário ou semanal de um responsável para que após o treinamento, os procedimentos sejam realizados de maneira correta durante todo o período escolar.

0 resultado apresentado na Figura 3 é preocupante, principalmente em virtude de que o Brasil é o país campeão de consumo mundial de agrotóxicos, utilizados na produção de alimentos. Alimentos contaminados podem ou não apresentar alterações na cor, sabor e odor. Diversas bactérias patogênicas, que são as principais causadoras de doenças transmitidas por alimentos, podem estar presentes nos alimentos sem serem detectadas, como por exemplo a Salmonella sp. Em casos de ocorrência de bactérias putrefadoras, normalmente ocorre odor desagradável, ou até mesmo murchamento, escurecimento, e apodrecimento. Porém, em muitos casos são identificados problemas de resíduos de pesticidas acima do permitido para consumo humano, em vários tipos de alimentos, em especial as frutas, legumes e hortaliças. A maior preocupação nesses casos é de que a contaminação química não apresenta sintomas perceptíveis ao ser humano, sendo detectadas apenas em testes de laboratório como é o caso dos agrotóxicos, antibióticos, resíduos de formol, água oxigenada, soda cáustica entre outros (CHITARRA e CHITARRA, 2005).

Figura 3. Resultados da questão: “Alimentos contaminados apresentam alteração somente de cor, sabor e odor?".

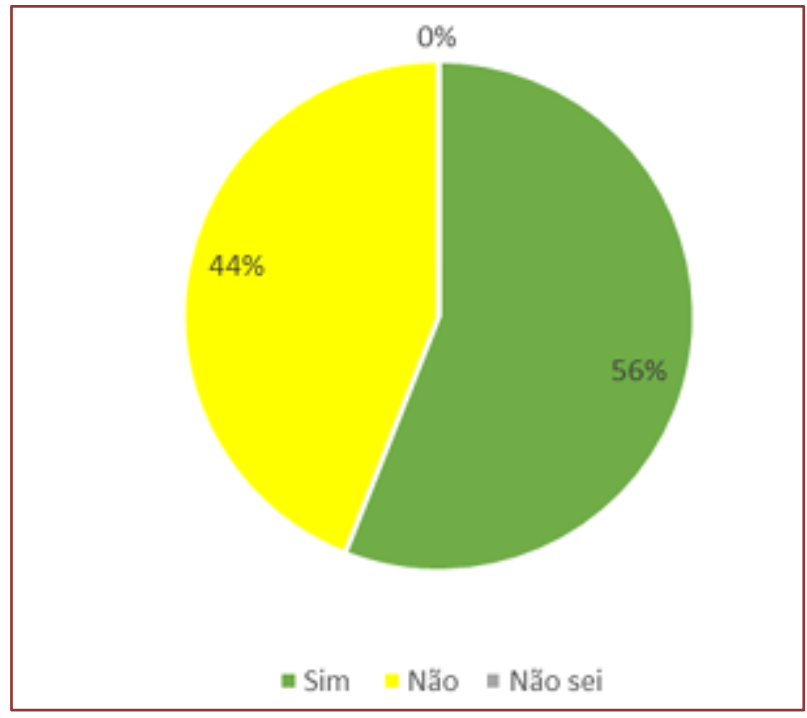

\section{CONSIDERAÇÕES FINAIS}

Pelos resultados apresentados pelas merendeiras, conclui-se que é necessário rever as técnicas de treinamento a fim de atingir mudança real do comportamento das merendeiras acerca da segurança dos alimentos. Questões básicas e simples, mesmo que tenham sido respondidas erroneamente por poucas merendeiras, devem ser incansavelmente trabalhadas para que as contaminações alimentares não aconteçam. Sugere-se que a formação dos manipuladores seja planejada através de modelo multidimensional, abrangendo fatores sociais, ambientais e organizacionais, com enfoque maior na percepção dos riscos que as práticas inseguras podem ocasionar. 


\section{REFERÊNCIAS}

[1] Brasil. Ministério da Educação. Fundo Nacional de Desenvolvimento da Educação e Alimentação Escolar, 2005. Disponível em: http: //www.fnde.gov.br. Acesso em dezembro de 2014.

[2] Brasil. Agencia Nacional de Vigilancia Sanitaria. Resolução número 328, de 22 de julho de 1999. Disponível em: http: //www.anvisa.gov.br/anvisalegis/resol/328_99.htm. Acesso em: 01 de dezembro de 2014.

[3] Brasil. Agencia Nacional de Vigilancia Sanitaria. Portaria svs/ms. № 326, de 30 de julho de 1997. Disponível em: http: // portal.anvisa.gov.br/wps/wcm/connect/cf430b804745808a8c95dc3fbc4c6735/Portaria+SVSS+N.+326+de+30+de+Julho+de+1997.pdf?Mod=Ajperes. Acesso em: dezembro de 2014.

[4] Brasil. Ministério da Saúde. Diretoria Colegiada da Agência Nacional de Vigilância

[5] Sanitária. Regulamento Técnico de Boas Práticas para serviços de alimentação. Resolução n²16 de 15 de setembro de 2004. Diário Oficial da União, Brasília, 2004.

[6] Brasil. Ministério da Saúde. Diretoria Colegiada da Agência Nacional de Vigilância Sanitária. Resolução RDC $\mathrm{n}^{\circ}$ 275, de 21 de outubro de 2002. Disponível em: <http://www.anvisa.gov.br/legis/resol/2002/275_ 02rdc.htm>.Acesso em 01 de dezembro de 2014.

[7] Chitarra, M. I. F.; Chitarra, A. B. Pós-colheita de frutos e hortaliças: fisiologia e manuseio. 2. ed. rev. e ampl. Lavras: UFLA, 2005. 


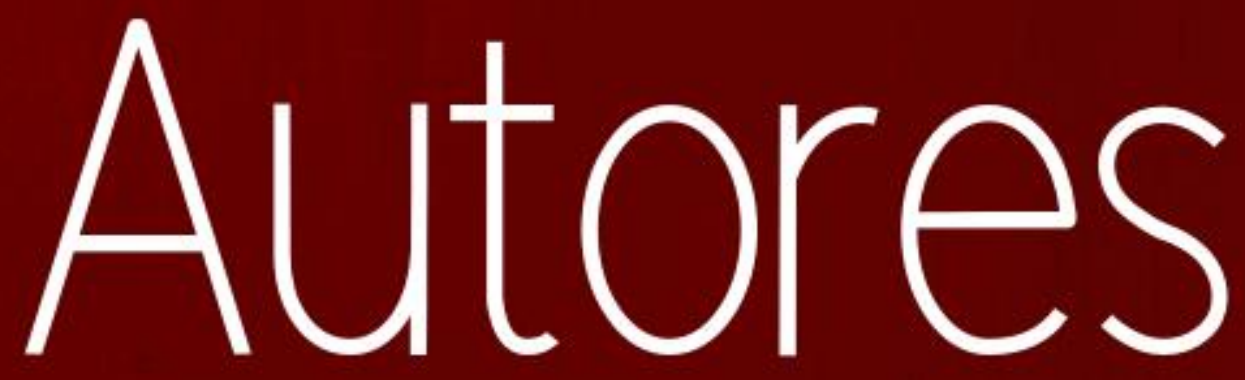




\section{ADRIANA SORAYA ARAÚJO}

Nutricionista graduada pela Universidade Federal do Maranhão (2011), Engenheira Agrónoma graduada pela Universidade Federal do Maranhão (2008). Pós-graduada em Nutrição Clínica Pelo Instituto de Pós Graduação (IPOG). Mestre em Saúde e Ambiente pela Universidade Federal do Maranhão (2018). Docente do curso de Nutrição pela Faculdade Pitágoras. Tutora presencial do curso Técnico em Alimentos pela Universidade Estadual do Maranhão. Participa como pesquisadora do Grupo de Pesquisa em Saúde e Ambiente do Maranhão - GPSAMA (UFMA).

\section{ADRIANO GOMES DA CRUZ}

Doutorado (2010) e Pós-Doutorado (2012) em Tecnologia de Alimentos pela Faculdade de Engenharia de Alimentos da Universidade Estadual de Campinas. Professor do Instituto Federal de Educação, Ciência e Tecnologia do Rio de Janeiro (IFRJ) no Departamento de Alimentos, atuando em ensino/pesquisa no curso técnico em Alimentos, especialização em Segurança dos Alimentos e Qualidade Nutricional de Alimentos e Mestrado Profissional em Ciência e Tecnologia de Alimentos. Coordenador do Mestrado Profissional de Ciência e Tecnologia de Alimentos do IFRJ e coordenador do Laboratório de Processamento de Alimentos e Laboratório de Análise Sensorial, pertencentes do Departamento de Alimentos/IFRJ. Coordenador ajunto de Mestrado Profissional em Ciência de Alimentos, CAPES (2018-2021). Foi Jovem Cientista FAPERJ (2014-2017) e Cientista do Nosso Estado FAPERJ (2018-2021). Docente permanente do Programa de Pós-Graduação em Higiene Veterinária e Processamento Tecnológico de Alimentos de Origem Animal (UFF), ministrando disciplinas em ciência e tecnologia de leite e derivados e análise sensorial. Editor da Coleção Lácteos composta de 4 volumes da Elsevier. Editor Associado do International Journal of Dairy Technology, do African Journal of Microbiological Research e da Food Science and Technology (Campinas).. Possui colaborações internacionais com a Universidade de Foggia (tália), Universidade do Minho (Portugal), Universidade de Melbourne (Austrália) e com a Shahid Beheshti University of Medical Sciences (Irã) e com Agriculture and Agri-Food (Canadá) com várias publicações em conjunto. Membro do corpo editorial do Journal of Dairy Science, Journal of Dairy Research, LWT-Food Science and Technology, Food Research International, Food Control, Polish Journal of Nutrition and Food Science, British Food Journal, International Journal of Food Science and Technology, Revista do Instituto de Laticínios Cândido Tostes e Indústria de Laticínios. Experiência docente e profissional na área em Ciência e Tecnologia de Alimentos, com ênfase em Ciência e Tecnologia de Leite e Derivados (processamento, estabilidade, comprovação dos benefícios de produtos lácteos (convencionais, prebióticos, probióticos, simbióticos e/ou baixo teor de sódio); físico-química, microbiologia, higiene, garantia da qualidade, análise sensorial, legislação e embalagens produtos lácteos, aproveitamento do subprodutos e tecnologias emergentes em produtos lácteo [(aquecimento ôhmico, ultrassom, plasma a frio, microondas, alta pressão)]. Análise Sensorial [métodos discriminativos, afetivos, descritivos (analise descritiva quantitativa, perfil livre, ultra flash profile, escalas de intensidade, sorting, mapa projetivo, mapa projetivo polarizado, mapa projetivo polarizado, free listing, CATA, comment analysis) e projetivos (focus group, associação de palavras, shooping list, completion task) e Quimiometria aplicada a ciência e tecnologia de alimentos (análise exploratória de dados (PCA e HCA), calibração multivariada (PLS, PCR e regressão linear múltipla) e métodos supervisionados de classificação [SIMCA,KNN, PLSDA, análise discriminante, redes neurais)] constituem também temas de grande interesse.

\section{AIANE BENEVIDE SERENO}

Graduada em Nutrição pela UNIBRASIL (2007-2011). Pós-graduada em Nutrição Clínica pela Faculdade Evangélica do Paraná (2011-2012). Mestre pelo Programa de Pós-Graduação em Alimentação e Nutrição do Setor de Ciências da Saúde da UFPR com ênfase em Qualidade dos Alimentos e Nutrição (2015-2017). Doutorado em andamento pelo Programa de Pós-Graduação em Medicina Interna HC/UFPR (2018). Nutricionista clínica e Pesquisadora em frutos da biodiversidade brasileira e ensaio clínico in vivo em diabetes. 


\section{ALEXANDRE HARGREAVES VIEIRA}

Possui graduação em Administração pela Universidade do Grande Rio (2006) e mestrado em Ciência e Tecnologia de Leite e Derivados pela Universidade Federal de Juiz de Fora (2014). Atualmente é coordenador do curso de leite e derivados - Núcleo Avançado em Tecnologia de Alimento e Gestão do Cooperativismo. Tem experiência na área de Ciência e Tecnologia de Alimentos, com ênfase em Tecnologia de Alimentos.

\section{AMANDA TEIXEIRA BITTENCOURT}

Nutricionista - Graduada no Curso de Nutrição pela Faculdade Fátima (2018).

\section{ANDERSON FERREIRA VILELA}

Técnico em Química (CEFET-MG), Técnico em Cervejaria (Câmara da Indústria e Comércio da Alta Baviera/SENAI-RJ), Farmacêntico (UFMG), Mestre em Ciência dos Alimentos (UFMG) e Doutor em Engenharia de Processos (UFCG). Professor da UFPB dos cursos técnico e superior de Agroindústria. Tem experiência na área de pesquisa, desenvolvimento e qualidade de bebidas, em especial cachaça e cerveja. http://lattes.cnpq.br/9345498036960185

\section{ÂNGELA MARIA SANTIAGO}

Graduada no curso de Engenharia Química pela Universidade Federal da Paraíba (UFPB) em 1981 e em Licenciatura em Química pela Universidade Regional do Nordeste (URNE) em 1982. Em 1983 conclui todos os créditos exigidos, com carga horária de 465 horas-aula, e tendo recebido o certificado de Especialista em Engenharia Sanitária e Ambiental pela UFPB, possui mestrado em Ciências e Tecnologia dos Alimentos pela UFPB em (1995) e doutorado em Engenharia de Processos pela Universidade Federal de Campina Grande-UFCG (2012), na área de Biotecnologia, em especial, produção e recuperação de enzimas pectinases utilizando resíduos da agroindústria. Atualmente é professora da Universidade Estadual de Campina Grande (UEPB), Campus I, no curso de graduação em Química Industrial ministrando os seguintes componentes curriculares: Tecnologia das Fermentações e Tecnologia dos Alimentos. Tem experiência nas áreas de Ciências e Tecnologia dos Alimentos e Biotecnologia, atuando principalmente na Produção e Conservação de Alimentos, Aproveitamento de Resíduos da Agroindústria, Desenvolvimento de Novos Produtos Alimentícios e na Produção e Purificação de Enzimas.

\section{ANTÔNIO SILVIO DO EGITO}

Farmacêutico pela Universidade Federal de Pernambuco - UFPE e Veterinário pela Universidade Federal Rural de Pernambuco - UFRPE, Mestre em Biotecnologia de Alimentos pela Universitat Politècnica de Catalunya, em Barcelona, Espanha e Doutor em Bioquímica pela Henri Poincaré Université, em Nancy, França. Pesquisador A da Empresa Brasileira de Pesquisa Agropecuária Embrapa, lotado no Núcleo Regional Nordeste da Embrapa Caprinos e Ovinos, em Sobral, Ceará / Embrapa Algodão, em Campina Grande, Paraíba, atuando nas áreas de Tecnologia do Leite e Derivados Caprinos, Bioquímica e Proteômica.

\section{ARIVONALDO BEZERRA DA SILVA}

É Especialista em Ensino de Matemática para o Ensino Médio pela UFRN. Possui graduação em Licenciatura em Química (2014) e Licenciatura em Matemática (2007) pela UFRN. Tem experiência como professor nas áreas de Química (2006 a 2013), Física (2004 a 2013) e Matemática (2004 a 2013). É Técnico em Alimentos pelo IFRN (2010) e foi Tutor Presencial do Curso de Química EaD da UFRN (Abril - Julho / 2016).

\section{ARTUR FARIA GONÇALVES}

Graduado Bacharel em Engenharia de Alimentos pela FIFE - Faculdades Integradas de Fernandópolis. Engenheiro de Alimentos. Responsável Técnico na Fábrica NILO Alimentos 


\section{BÁRBARA DORNELES PONTES}

Graduada em Nutrição pela Universidade Federal de Santa Maria (UFSM), campus de Palmeira das Missões, Pós-Graduada em Gestão de Unidades de Alimentação e Nutrição (UAN) pelo Instituto de Pesquisas Ensino e Gestão em Saúde (IPGS). Atualmente, atua como Gerente de Unidade em Restaurante Industrial.

\section{BRUNA DE SOUZA DA FONSECA}

Formanda do curso de Tecnologia em Alimentos pela Universidade Federal de Santa Maria (UFSM), colaboradora no Laboratório de Microbiologia da UFSM com ênfase em micropartículas e nanopartículas, atualmente atua como Auxiliar de Laboratório no Instituto SENAI de Tecnologia em Alimentos e Bebidas.

\section{BRUNO HENRIQUE DA SILVA MELO}

Mestrando do Programa de Pós-graduação em Química da Universidade Federal de Pernambuco UFPE, na área de Química Analítica. Graduado em Química Industrial pela Universidade Estadual da Paraíba - UEPB, onde atuou como monitor das disciplinas de Química Geral I, Química Experimental e Química Analítica Clássica Experimental. Foi bolsista de iniciação científica com projetos na área de Tecnologia dos Alimentos. Foi bolsista PIBIC e estagiário no Laboratório Avançado de Tecnologia Química - LATECQ da EMBRAPA - Algodão na cidade de Campina Grande $\mathrm{PB}$, atuando na identificação e quantificação de pegajosidade na fibra do algodão através de imagens hiperespectrais no infravermelho próximo e na obtenção e caracterização físico-química de ésteres metílicos de óleos vegetais para uso em adjuvantes agrícolas. Possui experiência em Tecnologia dos Alimentos com ênfase em aproveitamento de subprodutos e caracterização físicoquímica de alimentos, assim como na obtenção de biodiesel na área de Biocombustíveis.

\section{CARLA CRISTINA BAUERMANN BRASIL}

Possui graduação em Nutrição pela Universidade Franciscana (2006), especialização em Qualidade de Alimentos pelo Centro Brasileiro de Estudos Sistêmicos (2008), especialização em Higiene e Segurança Alimentar pela Universidad de León (2011), licenciatura pelo Programa Especial de Graduação de Formação de Professores para a Educação Profissional (2013), Mestrado e Doutorado em Ciência e Tecnologia dos Alimentos pela Universidade Federal de Santa Maria (UFSM) na linha de pesquisa Qualidade de Alimentos. Atua como docente do Curso de Nutrição da Universidade Federal de Santa Maria - campus Palmeira das Missões e participa de projetos de pesquisa e extensão na área de ciência e tecnologia de alimentos, com ênfase em sistemas de controle de qualidade de alimentos, microbiologia dos alimentos, análise sensorial de alimentos e legislações sanitárias voltadas a serviços de alimentação e indústria de alimentos.

\section{CARLOS RUAN VIEIRA DE SOUSA}

Engenheiro de Alimentos pela Universidade Federal do Ceará - UFC e Mestrando em Ciência e Tecnologia de Alimentos pela Universidade Federal do Ceará - UFC. Foi bolsista/estagiário da Embrapa Agroindústria Tropical, em Fortaleza, Ceará, de 2014 a 2016 em projetos de pesquisas relacionados com desenvolvimento de embalagens para alimentos, análise sensorial de queijos caprinos e extração de corantes naturais de co-produtos de frutos.

\section{CAROLINA CATALDO}

Nutricionista formada pela Universidade Federal do Rio de Janeiro (UFRJ/INJC), especialista em Gastronomia pela Universidade Federal do Estado do Rio de Janeiro (UNIRIO). Bolsista de iniciação cientifica, FAPERJ (2015). Atua na área de produção de refeições hospitalares. 


\section{CAROLINA PINTO DE CARVALHO MARTINS}

Doutoranda pelo Programa de Pós-Graduação em Ciência e Tecnologia de Alimentos da Universidade Federal Rural do Rio de Janeiro (Bolsista CAPES). Mestrado em Ciência e Tecnologia de Alimentos pelo Programa de Pós-Graduação em Ciência e Tecnologia de Alimentos da Universidade Federal Rural do Rio de Janeiro (Bolsista CAPES). Graduação em Nutrição pela Universidade Federal do Rio de Janeiro (Bolsista de Iniciação Científica PIBIC - UFRJ 2012-2014). Membro do Grupo de Pesquisa em Processamento de Frutas e Hortaliças UFRJ/ CNPq. Tem experiência nas áreas Ciência e Tecnologia de Alimentos, atuando principalmente nos temas: desenvolvimento de produtos funcionais, processamento de frutas e hortaliças e processamento de produtos lácteos.

\section{CASSANDRA DE DEUS}

Formada em Tecnologia em Alimentos pela Universidade Federal de Santa Maria - UFSM, RS. Fui bolsista no laboratório de desenvolvimento de micro e nanopartículas (106-NTA). Atualmente sou aluna do programa de pós-graduação nível de mestrado pela mesma instituição. Irei desenvolver micro partículas contendo extrato de planta bioativo juntamente com bactérias probióticas.

\section{CELSO FASURA BALTHAZAR}

Graduado em Medicina Veterinária pela Universidade Federal Fluminense (2011). Desenvolveu projetos de pesquisa na Fazenda da Universidade Federal Fluminense (criação, clínica e reprodução de pequenos ruminantes), foi estudante de iniciação científica (hematologia de peixes), possui experiência acadêmica na Escola de Veterinária da Universidade de Évora (Portugal), realizou estágio em fazenda privada de ovinos e laticínio; e realizou estágio no Laboratório Nacional da Qualidade do Leite (Universidade Federal de Minas Gerais), como atividades desenvolvidas durante a graduação. Tema de pós-graduação relacionado a produtos lácteos funcionais usando leite de ovelha. Mestrado (2014) e Doutorado (2018) em Higiene Veterinária e Processamento Tecnológico de Produtos de Origem Animal na mesma instituição da graduação. MBA (2015) em Segurança Alimentar e Qualidade Nutricional pelo Instituto Federal do Rio de Janeiro. Durante o doutorado, período colaborativo, no Departamento de Ciências Agrárias, Alimentos e Meio Ambiente da Universidade de Foggia (Itália). Realizou atividades relacionadas ao doutorado em diferentes Instituições Federais no Rio de Janeiro, Minas Gerais e São Paulo. Assim, possui experiência de trabalho em laboratório com diferentes grupos profissionais da grande área de Ciência de Alimentos em Instituições Nacionais e Internacionais. Encontra-se envolvido em projetos de parceria com Universidades em todo o Brasil, Itália e Austrália. Mais de 30 artigos internacionais com 481 citações, índice h: 15 e índice i10: 15. Experiência na produção de ovinos / caprinos, leite e derivados nas áreas de Ciência de Alimentos, Tecnologia e Inspeção de Produtos de Origem Animal, com foco na Tecnologia de Leite e Derivados Lácteos Funcionais (desenvolvimento e avaliação de produtos lácteos funcionais, como prebióticos, probióticos e simbióticos), qualidade, análises analíticas e nutricionais, bem como digestão gastrointestinal simulada in vitro; e aplicação de novas tecnologias (ultrassom e aquecimento ôhmico) no processamento de leites. Gestão da qualidade (ferramentas e sistemas) na indústria alimentar. Interesse atual visa à elaboração de produtos lácteos com apelo funcional pela adição de prebióticos e probióticos, com ênfase no desenvolvimento de produtos lácteos funcionais de leite não bovino e aplicação de novas tecnologias no processamento de laticínios.

\section{CLÁUDIA CARNEIRO HECKE KRÜGER}

Possui graduação em Nutrição pela UFPR (1989), mestrado em Tecnologia de Alimentos (2002) e doutorado no Programa de Pós Graduação em Tecnologia de Alimentos da UFPR (2006). Atualmente é professora Associada na Universidade Federal do Paraná e Coordenadora do Programa de Pós-Graduação em Alimentação e Nutrição. Atua nos seguintes temas: propriedades funcionais e fisiológicas de alimentos e matérias-primas alimentícias, leite bovino, caseinatos, soro de leite e caseinofosfopeptídeos, alfarroba, produtos lácteos com teor reduzido de lactose, qualidade nutricional de frutos da biodiversidade brasileira. 


\section{CLEBER LUIZ DE MOURA}

Possui graduação em Química pela Universidade Norte do Paraná(2011) e mestradoprofissionalizante em Tecnologia de Alimentos pela Universidade Tecnológica Federal do Paraná(2016). Atualmente é Analista da Qualidade Jr da Cia Cacique de Café Solúvel. Tem experiência na área de Química. Atuando principalmente nos seguintes temas:Resíduo industrial, GC-MS, transesterificação, pal.

\section{CRISTIANE LOPES PINTO FERREIRA}

Possui Graduação em Nutrição pela Universidade Federal de Mato Grosso (1999), Especialização em Nutrição Humana: Nutrição Hospitalar pela Universidade Federal de Mato Grosso (2001) e Mestrado em Ciências da Saúde pela Universidade Federal de Mato Grosso (2005). Atualmente é Professora do Instituto Federal de Educação Ciência e Tecnologia de Mato Grosso-Campus Bela Vista.

\section{CRISTIANO RAGAGNIN DE MENEZES}

Professor Associado do Centro de Ciências Rurais da Universidade Federal de Santa Maria. Possui graduação em Farmácia e Bioquímica pela Universidade Federal de Santa Maria (2003), Doutorado em Ciência de Alimentos pela FEA/UNICAMP (2007) e Pós-Doutorado em Ciência e Tecnologia de Alimentos pelo ITAL-SP (2009). Atua na área de Ciência de Alimentos com ênfase em Microbiologia, Micro e Nanoestrutura de Alimentos.

\section{DÁFFYNE KELLY SILVA COSTA OLIVEIRA}

Bacharel em Química Industrial graduada pela Universidade Federal do Maranhão - UFMA (2016) , Pós-graduada em Formação Pedagógica para Não-Licenciados em Química Licenciatura pela Universidade Cruzeiro do Sul (2019), Técnica em Alimentos formada pela Universidade Estadual do Maranhão - UEMA (2017), graduando em Educação Especial e Inclusiva pela Faculdade Dom Alberto.

\section{DAIANE APARECIDA DOS SANTOS}

Graduada em Tecnologia em Alimentos pela Universidade Tecnológica Federal do Paraná . Atuando como Assistente de Controle da Qualidade em entrepostos de ovos. Aplicação de legislações e programas de autocontrole.

\section{DAULTON RUAN RUFINO DE SOUZA}

É Graduado em Petróleo e Gás pela Universidade Potiguar, Brasil (2013). Atualmente é Assistente de Laboratório e Coordenador de Laboratórios do IFRN Campus Currais Novos.

\section{DEBORAH DOS SANTOS GARRUTI}

Engenheira de Alimentos, Mestre em Tecnologia de Alimentos e Doutora em Ciências de Alimentos pela Universidade Estadual de Campinas - Unicamp. Pesquisadora A da Empresa Brasileira de Pesquisa Agropecuária - Embrapa, lotada na Embrapa Agroindústria Tropical, em Fortaleza, Ceará. Possui experiência na área de Ciência e Tecnologia de Alimentos, com ênfase em análise sensorial, análise de compostos voláteis por cromatografia gasosa e olfatometria. Atua principalmente com perfil sensorial e de compostos voláteis responsáveis pelo sabor em genótipos de frutos; efeito dos tratamentos pós-colheita e do processamento sobre o perfil sensorial e de compostos voláteis; desenvolvimento de novos produtos e processos de alimentos vegetais. Docente permanente do Programa em Ciências Naturais da Universidade Estadual do Ceará - UECE, em Fortaleza, Ceará. 


\section{DEBORAH RODRIGUES SIQUEIRA}

Autora principal responsável pelo desenvolvimento da pesquisa, concepção e desenho do estudo; escrita e elaboração do manuscrito. Nutricionista formada pela Universidade Federal do Rio de Janeiro (UFRJ), Creditada como Supervisor em estabelecimentos de serviço de alimentação no Setor de Turismo - Segurança de alimentos pelo Sistema SENAI em conformidade com a Norma ABNT NBR 15048:2004. Mestre em Nutrição Clínica pelo Instituto de Nutrição Josué de Castro (UFRJ - INJC), especialista em Nutrição e Gastronomia pela Universidade Gama Filho (UGF); especialista em Segurança Alimentar e Qualidade Nutricional pelo Instituto Federal de Educação, Ciência e Tecnologia do Rio de Janeiro (IFRJ) e especialista em Alimentação Coletiva pela Associação Brasileira de Nutrição (ASBRAN). Atua na área de Nutrição e Ciências e Tecnologia de Alimentos com ênfase em desenvolvimento de produtos, alimentação coletiva, alimentos e produtos nutricionais com aplicação em nutrição clínica, gestão da qualidade e segurança de alimentos.

\section{DENISE PASTORE DE LIMA}

Possui graduação em Tecnologia de Alimentos pelo Centro Federal de Educação Tecnológica (2000), mestrado em desenvolvimento regional e agronegócio pela Universidade Estadual do Oeste do Paraná (2005) e Doutorado em Ciência de Alimentos pela Universidade Estadual de Maringá - UEM (2015). Atualmente é professora da Universidade Tecnológica Federal do Paraná, atuando nos cursos de Engenharia e Tecnologia de Alimentos. Tem experiência na área de Ciência de alimentos, atuando principalmente nos seguintes temas: Tecnologia de pescado, qualidade e segurança do alimento e microbiologia. Orientou um Mestrado, publicou 18 trabalhos em Anais de Evento, 49 Resumos Publicados em Anais de Eventos, 13 Artigos Completos Publicados em Periódicos, 4 capítulos de livro, 9 apresentações de trabalho, 12 trabalhos técnicos, cursos e treinamentos na área de segurança do alimento 61, orientou 63 monografias e 21 trabalhos de conclusão de cursos de graduação.

\section{DISNEY RIBEIRO DIAS}

Professor Associado I na Universidade Federal de Lavras - UFLA. Cursou graduação em Farmácia UNIFAL. Doutor em Ciência dos Alimentos - UFLA. Orientador de mestrado e doutorado no Programa de Pós-graduação em Microbiologia Agrícola - UFLA. Desenvolve atividades de pesquisa nas áreas de microbiologia e bioquímica de fermentações e enzimas microbianas.

\section{DIVA MENDONÇA GARCIA}

Possui graduação em Engenharia de Alimentos pela Pontifícia Universidade Católica de Goiás (2006) e mestrado em Ciência e Tecnologia de Alimentos pela Universidade Federal de Goiás (2009). Atualmente é professor efetivo do Instituto Federal de Educação, Ciência e Tecnologia de Goiás. Tem experiência na área de Ciência e Tecnologia de Alimentos, com ênfase em Tecnologia de Alimentos, atuando principalmente nos seguintes temas: sustentabilidade, produção de alimentos, análise sensorial, subproduto e fibra alimentar.

\section{EDILMA PINTO COUTINHO}

Engenheira Química (UFPE), Especialista em Engenharia de Segurança do Trabalho (UFPB), Mestre em Ciência e Tecnologia de Alimentos (UFPB), Doutora em Engenheira de Produção (UFRJ). Atualmente é professora da Universidade Federal Rural de Pernambuco. Sommelier de Cachaça, pelo SENAC-SP. Atua na área de Tecnologia de Alimentos, com destaque para Embalagem e Rotulagem e Tecnologia de Bebidas (Processamento e Gastronomia de Cerveja e Cachaça). http://lattes.cnpq.br/2457761897019367 


\section{ERICK ALMEIDA ESMERINO}

Possui graduação em Medicina Veterinária pela Universidade Federal Rural do Rio de Janeiro UFRRJ (2009), Mestrado (2012) e Doutorado (2016) em Alimentos e Nutrição pela Faculdade de Engenharia de Alimentos da Universidade Estadual de Campinas (UNICAMP) e Pós-doutorado em Higiene Veterinária e Processamento de Alimentos de Origem pelo Departamento de Tecnologia de Alimentos da Faculdade de Medicina Veterinária da Universidade Federal Fluminense (UFF). Professor Adjunto I da Universidade Federal Rural do Rio de Janeiro (UFRRJ) no curso de graduação em Engenharia de Alimentos; Professor Permanente do Programa de Pós-graduação em Ciência e Tecnologia (PGCTA) no Instituto Federal de Educação, Ciência e Tecnologia do Rio de Janeiro (IFRJ) e no Programa de Higiene Veterinária e Processamento Tecnológico de Produtos de Origem Animal da Faculdade de Medicina Veterinária, na Universidade Federal Fluminense (UFF). Reúne conhecimentos em Ciência e Tecnologia de alimentos, com ênfase em Análise Sensorial de Alimentos e Bebidas, Estudos de Consumidor, Tecnologia de Leite e Derivados, e uso de Tecnologias Emergentes (aquecimento ôhmico, plasma a frio e ultrassom) aplicadas ao desenvolvimento de produtos lácteos. Experiência ainda com metodologias qualitativas, discriminativas, descritivas tradicionais - Análise Descritiva Quantitativa (ADQ) - e afetivas, assim como tratamentos estatísticos aplicados à Análise Sensorial. Métodos rápidos e emergentes de caracterização sensorial, tais como: Mapa Projetivo (Napping), Sorting, Check-all-that-apply (CATA), Comment Analysis, Pivot Profile, Word Association Task e Free Listing, também estão entre as competências. Ademais, atua com métodos sensoriais dinâmicos como: Análise TempoIntensidade (TI), Progressive Profile, Temporal Dominance of Sensations (TDS) e Temporal Checkall-that-apply (TCATA) bem como o desenvolvimento e avaliação de produtos lácteos funcionais (Probióticos, Prebióticos e com teores reduzidos de sódio).

\section{EVANDRO MARTIN BRANDELERO}

Graduado em Agronomia pela UTFPR Campus Pato Branco (1999), Mestrado em Ciências Agrárias pela UFBA (2001) e doutorado em Agronomia pela UEL (2009). Tem experiência na área de Agronomia, com ênfase em Mecanização Agrícola e Manejo do solo e água, atuando principalmente nos seguintes temas: Desempenho de máquinas nas relações solo-máquina-planta, compactação de solos, uso de mulching biodegradável em ambientes protegidos Professor na UTFPR Campus Dois Vizinhos atuando nos cursos: Graduação em Agronomia e Zootecnia. Na Pós-graduação em Manejo da Fertilidade do Solo e Pós em Fitotecnia da cultura da soja.

\section{FERNANDA HART WEBER}

Possui graduação em Química Industrial de Alimentos pela Universidade Regional do Noroeste do Estado do Rio Grande do Sul (1998), mestrado em Ciência e Tecnologia Agroindustrial pela Universidade Federal de Pelotas (2001) e doutorado em Tecnologia de Alimentos pela Universidade Estadual de Campinas (2005). Atualmente é professora adjunta da Universidade Estadual do Rio Grande do Sul. Tem experiência na área de Ciência e Tecnologia de Alimentos, com ênfase em Tecnologia de Grãos e Cereais, Segurança Alimentar e Nutricional, atuando principalmente nos seguintes temas: tecnologia de alimentos, alimentos seguros.

\section{FRANCIS JOSÉ ZÓRTEA}

Possui Graduação em Tecnologia em Química Ambiental pela Universidade Tecnológica Federal do Paraná (2010), graduação em Farmácia pela Universidade Federal do Paraná (2013) e Mestrado em Ciências Farmacêuticas pela Universidade Federal do Paraná (2014). Durante o Mestrado atuou na área de pesquisa de insumos, medicamentos e correlatos, com ênfase em fitoquímica, química de produtos naturais, isolamento e identificação de substâncias, avaliação de atividade antioxidante, antibacteriana, toxicidade e atividade alelopática de extratos vegetais. Doutor em Ciências Farmacêuticas pela Universidade Federal do Paraná (2018) com o projeto de pesquisa sobre atividades biológicas e avaliação farmacológica dos extratos e compostos isolados de espécies vegetais. Atualmente é Pós-doutorando no Centro de Estudos em Biofarmácia da Universidade Federal do Paraná. 


\section{GLACIELA CRISTINA RODRIGUES DA SILVA SCHERER}

Mestre em Engenharia de Alimentos, pela Universidade Regional Integrada do Alto Uruguai e das Missões - Uri Campus Erechim, Especialista em Segurança Alimentar e Agroecologia e Graduada em Tecnologia em Agroindústria pela Universidade Estadual do Rio Grande do Sul, Região IV Unidade de Três Passos. Atualmente cursa Doutorado em Engenharia de Alimentos pela Universidade Regional Integrada do Alto Uruguai e das Missões - URI Campus Erechim e Graduanda em Engenharia de Alimentos pelo Instituto Federal de Educação, Ciência e Tecnologia do Rio Grande do Sul - IFRS Campus Erechim.

\section{GUILHERME LANDIN SANTOS}

Aluno de Graduação em Engenharia Florestal, participou nos projetos de pesquisa na área de materiais biodegradáveis e sustentáveis de 2017 a 2019, como bolsista de iniciação científica, sendo seu trabalho reconhecido pela conquista da premiação como melhor trabalho na área multidisciplinar apresentado na Semana de Iniciação Científica edição de 2018 da Universidade que estuda.

\section{HARDI GERMANO WEIRICH}

Possui graduação em Planejamento e Gestão para o Desenvolvimento Rural pela Universidade Federal do Rio Grande do Sul(2011) e especialização em Especialização em Segurança Alimentar e Agroecologia pela Universidade Estadual do Rio Grande do Sul(2015). Atualmente é Técnico de Laboratório da Escola Estadual de Educação Básica Padre Gonzales e Técnico de Laboratório da Universidade Estadual do Rio Grande do Sul. Tem experiência na área de Agronomia, com ênfase em Extensão Rural.

\section{HELENA TEIXEIRA GODOY}

Possui graduação em Farmácia e Bioquímica pela Universidade de São Paulo (1981), mestrado em Ciência de Alimentos pela Universidade Estadual de Campinas (1985) e doutorado em Ciência de Alimentos pela Universidade Estadual de Campinas (1993). Realizou sua Livre-Docência em 2003. Atualmente é Professor Titular na Faculdade de Engenharia de Alimentos da Universidade Estadual de Campinas. Foi Membro do Comitê de Assessoramento da Área de Ciência e Tecnologia de Alimentos do Conselho Nacional de Desenvolvimento Científico e Tecnológico/CNPq. Recebeu prêmios/homenagens, destacando-se o Prêmio de Reconhecimento Acadêmico; Zeferino Vaz; em 2007e os Prêmios Capes de Tese 2009 e o CAPES de Tese 2015 - Menção Honrosa. Publicou mais de 150 artigos em periódicos especializados e 400 trabalhos em anais de eventos. Participou em mais de 100 eventos no Brasil e no exterior. Orienta trabalhos de Iniciação Científica, Conclusão de Curso na Área de Ciência e Tecnologia de Alimentos, dissertações de Mestrado e teses de Doutorado, além de supervisionar pós-doutorado. Coordenou e participou em mais de 60 projetos de pesquisa. Tem experiência na área de Ciência e Tecnologia de Alimentos, com ênfase em Análise de Alimentos. Os termos mais frequentes que caracterizam a produção científica são: desenvolvimento e validação de métodos analíticos, cromatografia, eletroforese capilar, espectrometria de massas, técnicas de preparação de amostra, ácido fólico, vitaminas, aditivos, compostos fenólicos, carotenoides, capacidade antioxidante, compostos voláteis, bioacessibilidade. Participou ativamente da pós-graduação, tanto a nível da UNICAMP-FEA como nacional.

\section{HELENICE DUARTE DE HOLANDA}

Engenheira de Alimentos (UFPB), Mestre em Ciência e Tecnologia de Alimentos (UFPB), Doutora em Alimentos e Nutrição (UNICAMP). Professora da UFPB tem experiência na área de Ciência e Tecnologia de Alimentos, com ênfase em Tecnologia de Frutas e Hortaliças e Aproveitamento de Subprodutos, atuando principalmente na composição química e processos. 


\section{IDILA MARIA DA SILVA ARAÚJO}

Tecnóloga de Alimentos pelo Instituto Centro de Ensino Tecnológico - CENTEC, no Cariri, Ceará, Bacharel em Ciências Biológica e Mestre em Bioprospecção Molecular, ambos pela Universidade Regional do Cariri - URCA, no Cariri, Ceará, Doutora em Ciências Biológicas pela Universidade Federal de Pernambuco - UFPE e Pós-Doutora pela Universidade Nacional de La Plata, em La Plata, Argentina. Analista da Embrapa Agroindústria Tropical, em Fortaleza, Ceará atuando no Laboratório de Análise de Alimentos com análise sensorial, físico-química, instrumental e olfatometria de alimentos. Possui experiência nas áreas de físico-química/bromatologia; análise sensorial de alimentos e bioquímica com ênfase em química de proteínas/purificação, caracterização e avaliações de atividades biológicas de lectinas. Atualmente leciona disciplinas de Análise Sensorial e Métodos de Análises de Alimentos nos Cursos de Especializações em Ciência de Alimentos e Vigilância Sanitária de Alimentos da Universidade Estadual do Ceará - UECE, em Fortaleza, Ceará.

\section{ILANA MORGANA FERREIRA ARAÚJO DOS SANTOS}

Formada em Técnica de Enfermagem pelo Instituto Florence de Ensino (2010), Técnica em Alimentos pela Universidade Estadual do Maranhão (2017)

\section{ISABEL CRAVEIRO MOREIRA}

Possui graduação em Engenharia Química pela Universidade Federal Rural do Rio de Janeiro (1991), mestrado em Química pela Universidade Federal Rural do Rio de Janeiro (1994) e doutorado em Química Orgânica pela Universidade de São Paulo (1999). Atualmente é professora de ensino básico, técnico e tecnológico da Universidade Tecnológica Federal do Paraná. Tem experiência na área de Química, com ênfase em Química dos Produtos Naturais, atuando principalmente nos seguintes temas: atividade antioxidante, produtos naturais, funcionalidade de alimentos.

\section{ISANDRA DE FRANÇA MEDEIROS}

Especialista em Tutoria para as Diversas Licenciaturas à Distância pela Universidade Federal de Pernambuco (UFPE, 2006), Química Industrial pela Universidade Estadual da Paraíba (UFPB, 2003), graduanda em Química Licenciatura pela Universidade Federal do Rio Grande do Norte (UFRN) e pós-graduanda em Ciência e Tecnologia de Alimentos (IFRN). Tem experiência e interesse na área de Alimentos, com ênfase em leite e seus derivados, polpas de frutas e água potável, e na área de Química, com saneantes, especialmente.

\section{ISAURA HAMMERSCHMITT CLEMENTE}

Possui graduação em Nutrição pela Universidade Federal de Santa Catarina (1997). Trabalha com assessoria no Restaurante Barriga Verde desde 2003, no Senac responsável pelo Programa Senac de Segurança de alimentos desde 2003. Tem experiência na área de Nutrição, com ênfase em Gestão de Restaurantes, Segurança de Alimentos e Técnica Dietética, bem como layout e equipamentos para áreas de produção.

\section{JOSÉ TEIXEIRA FILHO}

Possui graduação em Escola Politécnica pela Universidade de São Paulo(1981), mestrado em Hydrologie Science de 1 Eau Et Amenagement pela Université Montpellier 2 - Sciences et Techniques(1992), mestrado em Escola Politécnica pela Universidade de São Paulo(1989) e doutorado em Gestão de Recursos Hídricos pela Université Montpellier 2 - Sciences et Techniques(1995). Atualmente é professor Livre-Docente da Universidade Estadual de Campinas e do Instituto Nacional de Pesquisas Espaciais. Tem experiência na área de Engenharia Civil, com ênfase em Hidrologia Ciência da Agua e Gestão. Atuando principalmente nos seguintes temas: Hdirologia, Gestão dso Recursos Hídricos, modelagem hidrológica, modelagem de qualidade de agua, modelo de previsão. 


\section{JULIA MENDES DE LIMA}

Graduanda em Química Industrial pela Universidade Estadual da Paraíba - UEPB. Possui experiência em Tecnologia dos Alimentos com ênfase em aproveitamento de subprodutos e caracterização físico-química de alimentos, bem como na área de Galvanoplastia, em processos com zinco, cromo e níquel.

\section{KARINA TEIXEIRA MAGALHÃES-GUEDES}

Bióloga, CRBio: 076708/04-D. Doutora em Ciências (Microbiologia Agrícola) - UFLA, com período sandwich na Universidade do Minho - UMINHO (Portugal). Pós-Doutora em Biotecnologia - UFLA e UFBA. Membro do Corpo Docente Orientador do Programa de Pós-graduação em Ciência de Alimentos (PGALi) da Universidade Federal da Bahia - UFBA. Atua em tecnologia do Kefir, Kombuchá e Spirulina platensis, Aplica técnicas bioquímicas, biologia molecular e técnicas espectrais Maldi-Tof e Biospeckle laser.

\section{KARLA VITÓRIA A. SAMPAIO}

Possui técnico em Agroindústria pelo Instituto Federal de Goiás (2017), graduanda em Medicina Veterinária pela Pontifícia Universidade Católica de Goiás.

\section{KATIANE APARECIDA WILLY}

Possui graduação em Tecnologia em Alimentos pela Universidade Tecnológica Federal do Paraná UTFPR, fevereiro de 2015. Atua em Consultoria na área de Qualidade de indústrias alimentícias. Cursos e treinamentos na área de segurança de alimentos 05.

\section{KEROLAYNE SANTOS LEITE}

Engenheira de Alimentos (UFPB), Especialista em Engenharia de Segurança do Trabalho (Centro Universitário de João Pessoa), Mestre em Engenharia Mecânica (UFPB). Tem experiência na área de Ciência e Tecnologia de Alimentos com ênfase em processos de fabricação, segurança alimentar, resíduos agroindustriais, filmes biodegradáveis e caracterização de materiais. Professora no Curso Técnico em Agroindústria do IFAL.

\section{LAURA GABRIELA MAGNABOSCO}

Graduanda de Biomedicina pela UNISOCIESC - Florianópolis, faz parte do programa de Iniciação Cientifica como voluntária no laboratório de Neuroquímica IV, Universidade Federal de Santa Catarina - UFSC, orientada pela Prof. Dra. Carla Inês Tasca. Possui experiência nas áreas de Ciências da Saúde com ênfase em Bioquímica e Neuroquímica.

\section{LEONARDO DE ALMEIDA MARCIANO}

É Graduado em Engenharia Quimica pela Universidade Federal do Rio Grande do Norte, Brasil (2010. Atualmente é Assistente em Administração e diretor da Usina Escola do IFRN Campus Currais Novos.

\section{LISANDRA FERREIRA DE LIMA}

Possui graduação (1999), mestrado (2002), doutorado (2005) e pós doutorado(2016) em Engenharia Química pela Universidade Estadual de Maringá. Já atuou como docente na UEM, CEFET-GO, UFS. É professora adjunto da Universidade Tecnológica Federal do Paraná desde 2009. Tem experiência na área de Engenharia Química e de Alimentos, atuando principalmente nos seguintes temas: Tecnologia supercrítica ( reações e extração), Biocombustíveis, Ensino de Engenharia e Constante dielétrica em fase líquida. Já atuou como coordenadora de curso (2007), Diretora de pesquisa e pós-graduação (2009) e Assessora de Lato Sensu (2011). Presidiu a 
comissão de elaboração do projeto de abertura do curso de Engenharia Química do campus Londrina.

\section{LÍVIA B. SOUSA}

Tem experiência na área de Agronomia, com ênfase em Agroindústria, bem como em Ciências Sociais, com ênfase em Sociologia .

\section{LUCAS NACHTIGAL DUARTE}

Acadêmico do curso de Tecnologia em Alimentos pelo Instituto Federal Farroupilha Campus Santo Augusto (IFFar), RS. Bolsista em projeto de pesquisa elaborando e caracterizando produtos alimentícios utilizado novos genótipos de batata-doce biofortificada. Atuei como estagiário no Laboratório/Área Alimentos do IFFar.

\section{LUCAS VAZ DA ROSA}

Graduando em Nutrição - Centro Universitário Estácio de Santa Catarina. Com experiência na área de Ciências da Saúde e Nutrição esportiva; com prática empresarial em Suplementação Esportiva.

\section{LUCIANA DE ABREU}

Estudou Química Industrial de Alimentos na instituição de ensino UNIJUÍ - RS. Estudou Mestre em Ciência e Tecnologia dos Alimentos/PPGCTA - UFSM- Universidade Federal de Santa Maria

\section{LUCIANA GIBBERT}

Possui graduação em Nutrição pela Universidade Federal da Fronteira Sul- UFFS (2014) e mestrado em Alimentação e Nutrição pela Universidade Federal do Paraná-UFPR (2017). Atualmente é doutoranda em Ciências Farmacêuticas na Universidade Federal do Paraná, trabalhando na área de produtos naturais. Atua principalmente nos seguintes temas: tecnologia de alimentos, nutrição experimental, controle e qualidade de alimentos, bioquímica de alimentos, Diabetes melito, e biodiversidade brasileira.

\section{LUIS EDUARDO LAGUNA}

Médico Veterinário e Zootecnista pela Universidad Del Tolima, em Ibagué-Tolima, Colômbia e Mestre em Tecnologia de Alimentos pela Universidade Federal do Ceará - UFC. Pesquisador da Empresa Brasileira de Pesquisa Agropecuária - Embrapa, lotada na Embrapa Caprinos e Ovinos, em Sobral, Ceará. Possui experiência na área de Ciência e Tecnologia de Alimentos, atuando em principalmente em tecnologia do leite de cabra e derivados, composição centesimal, processamento e controle de qualidade.

\section{LYSSA SETSUKO SAKANAKA}

Professora dos cursos de graduação em Tecnologia em Alimentos e Mestrado Profissional em Tecnologia de Alimentos da Universidade Tecnológica Federal do Paraná -campus de Londrina. Tem experiência na área de Ciência e Tecnologia de Alimentos, atuando principalmente nos seguintes temas: embalagens biodegradáveis, extrusão de polímeros biodegradáveis, secagem, bebidas a base de matéria-prima vegetal.

\section{MARCELO BARBOSA MUNIZ}

Engenheiro Agrônomo (UFPB), Mestre em Engenharia Agrícola (UFCG), Doutor em Engenharia de Processos (UFCG) e Pós-doutor em Engenharia de Processos na UFCG. Atua em Biotecnologia de Alimentos, Processos Químicos e Aproveitamento de Alimentos. Professor efetivo do Departamento de Engenharia de Alimentos da UFPB. 


\section{MÁRCIA KELLER ALVES}

Nutricionista - Graduada no Curso de Nutrição pelo Instituto Porto Alegre da Igreja Metodista (2003). Graduanda em Tecnologia dos Alimentos pelo Instituto Federal do Rio Grande do Sul (Bento Gonçalves). Mestre em Biologia Celular e Molecular pela Pontifícia Universidade Católica do Rio Grande do Sul (2006). Doutoranda em Biotecnologia pela Universidade de Caxias do Sul (UCS). Docente do Curso de Nutrição da Faculdade Fátima (Caxias do Sul/RS). Coordenadora do Núcleo de Estudos e Pesquisas em Alimentos e Nutrição (NEPAN) da Faculdade Fátima (Caxias do Sul/RS). Docente e Coordenadora do Curso de Nutrição da Faculdade Anhanguera (Caxias do Sul/RS).

\section{MARIA DE FÁTIMA DE SOUSA CASCAES}

Técnica em Alimentos formada pela Universidade Estadual do Maranhão - UEMA (2016).

\section{MARIA FERNANDA DA SILVEIRA CÁCERES DE MENEZES}

Técnica em Laboratório de Alimentos do Instituto Federal Farroupilha Campus Santo Augusto. Graduada em Química de Alimentos pela Universidade Federal de Pelotas, Especialista em Ciência dos Alimentos (UFPel), Mestra e Doutoranda em Ciência e Tecnologia de Alimentos (PPGCTA/UFSM), atuando no desenvolvimento de micropartículas de pectina com multicamadas proteicas para proteção de L.acidophilus frente a condições de estresse.

\section{MARIA LÚCIA MENDES LOPES}

Possui graduação em Nutrição pela Universidade Federal de Viçosa, mestrado em Ciência e Tecnologia de Alimentos pela Universidade Federal Rural do Rio de Janeiro e doutorado pelo Instituto de Nutrição Josué de Castro da Universidade Federal do Rio de Janeiro, com período sanduíche pela The Ohio State University. Co-orientou dissertações de mestrado. Desenvolve pesquisas na área de ciência e tecnologia, processamento e controle de qualidade de alimentos, atuando principalmente nos seguintes temas: segurança de alimentos, controle de qualidade de alimentos e alimentos funcionais.

\section{MARIA ROSA FIGUEIREDO NASCIMENTO}

Possui graduação em Economia Domestica pela Universidade Federal Rural do Rio de Janeiro (1986), mestrado em Ciência e Tecnologia de Alimentos pela Universidade Federal Rural do Rio de Janeiro (2008) e Doutora em Ciência e Tecnologia de Alimentos na Universidade Federal Rural do Rio de Janeiro (2014). Atualmente é professora da Universidade Federal Rural do Rio de Janeiro, atuando principalmente nos seguintes temas: alimentação, processamento de alimentos, boas práticas de higiene e manipuladores de alimentos, aproveitamento de resíduos, técnicas de prépreparo.

\section{MARLENE BAMPI}

Possui graduação em Engenharia de Alimentos pela Universidade Estadual do Centro-Oeste (2007), Mestrado pela Universidade Federal do Paraná (2011) e Doutorado em Engenharia de Alimentos pela Universidade Federal de Santa Catarina (2015). Atualmente é professora do Departamento de Engenharia de Alimentos e Engenharia Química da Universidade do Estado de Santa Catarina. Tem experiência com processos de secagem e determinação de compostos fenólicos e antioxidantes

\section{MASTRANGELLO ENIVAR LANZANOVA}

Formado Técnico em Agropecuária no Ensino Médio, possui Graduação em Agronomia pela Universidade Federal de Santa Maria (2002), Mestrado em Ciência do Solo pela UFSM (2005) e Doutorado em Engenharia Agrícola pela UFSM (2009). Atualmente é professor Adjunto da Universidade Estadual do Rio Grande do Sul - UERGS, unidades Três Passos e São Luiz Gonzaga. Tem experiência na área de Agronomia, com ênfase em Manejo e Conservação do Solo, Integração 
Lavoura-Pecuária, e Agroecologia, atuando principalmente nos seguintes temas: manejo do solo, sistema plantio direto, adubos verdes, planejamento agropecuário, erosão e compactação do solo.

\section{MILENA S. CORREIA}

Possui ensino-fundamental-primeiro-graupelo Colégio Estadual Juscelino Kubitischek de Oliveira (2014) e ensino-medio-segundo-graupelo Instituto Federal de Educação, Ciência e Tecnologia de Goiás(2017).

\section{MÔNICA QUEIROZ DE FREITAS}

Professora Titular do Departamento de Tecnologia dos Alimentos, da Universidade Federal Fluminense, Niterói/RJ. Possui graduação em Medicina Veterinária pela Universidade Federal Fluminense (1985), mestrado em Medic.Veterinária (Hig.Veter.Proc.Tecn.Prod.Orig.Animal) pela Universidade Federal Fluminense (1991), doutorado em Ciência e Tecnologia de Alimentos pela Universidade Federal de Viçosa (2001) e pós-doutorada no Instituto de Biotecnologia da Universidade Católica do Porto/PT (2012). Desde 1991 é professora do Departamento de Tecnologia dos Alimentos da Faculdade de Medicina Veterinária da Universidade Federal Fluminense. Tem experiência na área de Ciência e Tecnologia de Alimentos, com ênfase em Avaliação e Controle de Qualidade de Alimentos, atuando principalmente nos seguintes temas: análise sensorial de alimento e bebida e inspeção sanitária de produtos de origem animal. Atualmente está coordenando o Programa de Pós-Graduação em Higiene Veterinária e Processamento Tecnológico de Produtos de Origem Animal da Universidade Federal Fluminense. É bolsista de produtividade do CNPq e de Cientista do Nosso Estado (CNE/FAPERJ).

\section{NÁGELA FARIAS MAGAVE PICANÇO SIQUEIRA}

Possui graduação em Licenciatura em Economia Doméstica pela Universidade Federal Rural do Rio de Janeiro (1991), mestrado em Ciência e Tecnologia de Alimentos pela Universidade Federal Rural do Rio de Janeiro (2003) e doutorado em Agronomia (Energia na Agricultura) pela Universidade Estadual Paulista Júlio de Mesquita Filho (2010). Atualmente é professora titular do Instituto Federal de Educação, Ciência e Tecnológica de Mato Grosso, professora titular - UAB. Tem experiência na área de Ciência e Tecnologia de Alimentos, com ênfase em desenvolvimento tecnológico de produtos com frutos nativos do cerrado, atua principalmente na área de desenvolvimentos de novos produtos, fisico-química e microbiologia de alimentos.

\section{OSMAR CAÔN FILHO}

Químico Industrial pela Universidade Metodista de Piracicaba, mestre em Física e doutor em Biofísica pelo Ibilce/Unesp - S J do Rio Preto - SP. Docente a Universidade Paulista (Unip - S J do Rio Preto - SP) e da Fundação Educacional de Fernandópolis (FEF) nas disciplinas de FísicoQuímica, Química Orgânica e Bioquímica. Coordenador pedagógico do curso de Química da Fundação Educacional de Fernandópolis - SP.

\section{PABLÍCIA OLIVEIRA GALDINO}

Graduada em Química Industrial pela Universidade Estadual da Paraíba (2001), Mestre em Engenharia Agrícola pela Universidade Federal da Paraíba (2003) na área de Armazenamento e Processamento de Produtos Agrícolas e Doutora em Engenharia Agrícola pela Universidade Federal de Campina Grande (2012) na área de Armazenamento e Processamento de Produtos Agrícolas. Foi professora na Universidade Federal da Paraíba (UFPB). Atualmente é professora Doutora Nível C, em regime efetivo, da Universidade Estadual da Paraíba no Centro de Ciências e Tecnologia. Tem experiência na área de Química e Bioquímica, com ênfase em alimentos, atuando principalmente nos seguintes temas: agroindústria, tecnologia de alimentos, fruticultura, características físico-químicas, qualidade microbiológica, armazenamento, embalagem e desenvolvimento de novos produtos. 


\section{PLÚVIA OLIVEIRA GALDINO}

Graduada no curso de Agronomia pela Universidade Federal da Paraíba (2008), possui mestrado em Engenharia Agrícola (2011) e doutorado em Engenharia Agrícola (2015), ambos na área de Armazenamento e Processamento de Produtos Agrícolas pela Universidade Federal de Campina Grande (UFCG). Atualmente é professora Adjunto da Universidade Federal de Campina Grande (UFCG), Campus Pombal, no curso de graduação em Engenharia de Alimentos, no qual ministra as seguintes disciplinas: Química de Alimentos II, Tecnologia de Materiais e Embalagens para Alimentos, Higiene na Indústria de Alimentos e Secagem de Produtos Agrícolas. Tem experiência na área de Agronomia e Engenharia de Alimentos, atuando principalmente nos seguintes temas: Pós Colheita de Produtos Agrícolas, Ciência e Tecnologia de Alimentos, Bioquímica de Alimentos, Métodos de Conservação de Alimentos e Desenvolvimento de Novos Produtos Alimentícios.

\section{POLLYANE DA SILVA PORT'S}

Possui Graduação em Tecnologia de Alimentos pela Universidade do Estado do Pará (2007), Mestrado em Ciência de Alimentos pela Universidade Estadual de Campinas - UNICAMP (2011) e Doutorado em Ciência de Alimentos pela Universidade Estadual de Campinas - UNICAMP (2015). Foi bolsista (CNPq) de Pós-doutorado na Universidade de Cádiz (Espanha) em 2016. Possui experiência na área de processamento tecnológico de matérias-primas vegetais, assim como análises físico-químicas e fitoquímicas em produtos de origem vegetal. Desenvolve pesquisas relacionada a otimização e validação de métodos para análise de composição química em alimentos, atuando no estudo de métodos de extração para pigmentos naturais e compostos bioativos em matrizes alimentícias, além de métodos de recuperação, isolamento, identificação e quantificação de substancias por cromatografia líquida (HPLC), espectrometria de massas (MS), cromatografia em fase gasosa (GC), entre outras técnicas analíticas.

\section{RAMON ARAÚJO DOS SANTOS}

Possui curso técnico em Alimentos pelo Instituto Federal de Educação Ciência e Tecnologia do Rio Grande do Norte - IFRN (2010) e graduação em Tecnologia em Alimentos pelo IFRN (2016) . Atualmente é Técnico em Alimentos e Laticínios do IFRN - Campus Currais Novos, Responsável Técnico da Estação de Tratamento e Distribuição de Água Potável para Consumo Humano Chafariz Rodrigues e mestrando da pós-graduação de Ciência e Tecnologia de Alimentos da Universidade Federal da Paraíba. Desenvolve pesquisas nas áreas de leite e derivados, análises de alimentos e água e desenvolvimento de novos produtos.

\section{RENATA CUNHA DOS REIS}

Possui graduação em Engenharia de alimentos pela Universidade Federal de Goiás (2008), mestrado em Engenharia Agrícola pela Universidade Estadual de Goiás (2011) e doutorado em Ciência Animal pela Universidade Federal de Goiás (2017) . Atualmente é professor - ensino básico, téc. e tecnológico do Instituto Federal de Educação, Ciência e Tecnologia de Goiás (IFG).

\section{RENATA LABRONICI BERTIN}

Nutricionista graduada pela Pontifícia Universidade Católica do Paraná (2004). Mestre em Nutrição pela Universidade Federal de Santa Catarina (2006). Doutora em Ciência dos Alimentos pela Universidade Federal de Santa Catarina (2014). Especialista em Nutrição Esportiva (2018). No mestrado, trabalhou com concepções e práticas do nutricionista na área hospitalar. Durante o doutorado estudou sobre compostos bioativos em alimentos. Atualmente é professora adjunta do Departamento de Nutrição da Universidade Federal do Paraná (UFPR), em que ministra disciplinas relacionadas à área de nutrição básica, bioquímica e análise de alimentos, nutrição e atividade física e prática ambulatorial para rendimento esportivo. Realiza pesquisas com enfoque na nutrição, fatores de risco e promoção a saúde em jovens universitários, consumo alimentar e nutrição na prática esportiva voltada para adolescentes. Membro do Núcleo Docente Estruturante (NDE) do Curso de Nutrição, do Comitê de Ética em Pesquisa com Seres Humanos do Setor de 
Ciências da Saúde e Vice-coordenadora da Especialização em Medicina do Exercício Físico na Promoção da Saúde (UFPR).

\section{RENATA PAULA HERRERA BRANDELERO}

Professora Universitária desde 2005, atuando no Ensino Superior e na Pesquisa Acadêmica. Bacharel em Quimica. Mestre e Doutora em Ciências dos Alimentos. Desenvolve pesquisas na área de materiais biodegradáveis a base de biopolímeros e polímeros naturais com expertise em filmes finos biodegradáveis para embalagens alimentares. Atualmente pesquisa e desenvolve fertilizante nitrogenado para liberação lenta a fim de minimizar o impacto ambiental dos fertilizantes nitrogenados no ambiente

\section{ROBERTA JULIANO RAMOS}

Atualmente é Profa. do Centro Universitário Estácio de Santa Catarina, nos cursos de Nutrição e Farmácia, onde ministra as disciplinas de Bromatologia, Microbiologia de Alimentos, Administração de UAN e Análise sensorial de alimentos, além de coordenar o Estágio Supervisionado em Unidades de Alimentação e Nutrição e Coordenar projetos de pesquisa no curso de Nutrição. Possui mestrado (2007) e doutorado (2012) em Ciência dos Alimentos pela Universidade Federal de Santa Catarina. Graduada em Nutrição pela Universidade Federal de Pelotas (2004). Curso Técnico em Química pela Escola Técnica Federal de Pelotas (1995).

\section{ROBERTA OLIVEIRA VIANA}

Graduada em Ciências Biológicas e Mestre em Ciências (Microbiologia Agrícola) pela Universidade Federal de Lavras - UFLA. Atuou como monitora da disciplina microbiologia geral durante sua graduação e trabalhou em laboratório de microbiologia como aluna de iniciação científica. Atualmente cursa doutorado em Microbiologia na Universidade Federal de Minas Gerais - UFMG.

\section{ROBERTO ALVES BRAGA JR.}

Prof. Titular na Universidade Federal de Lavras - UFLA, Bolsista CNPq 1A, e professor externo no Mestrado em Física Médica na Universidade de Valência, Espanha. Área de atuação em Metrologia Óptica. Realiza trabalhos com Biospeckle laser. Responsável pelo Centro de Desenvolvimento de Instrumentação aplicada à Agropecuária (Finep-UFLA).

\section{ROBERTO KELWIN LOPES DA COSTA E LOPES}

Engenheiro de Alimentos, formado pela Universidade Federal da Paraíba. Atualmente atua como Encarregado de controle de produção, na Indústria Alimentícia 3 de Maio S/A. http://lattes.cnpq.br/6501889822870888. Gostaríamos de fazer uma homenagem póstuma a AMANDA DA SILVA GOMES que contribuiu para a realização desse trabalho, mas que infelizmente não está entre nós para ter a felicidade de ver sua publicação num livro.

\section{RONEL JOEL BAZÁN COLQUE}

Graduação em Engenharia de alimentos pelo Universidad Nacional Agraria de la Selva, Peru (2013), Mestrando em Ciência e Tecnologia de Alimentos pela Universidade Federal Rural de Rio de Janeiro (2018) e estagiário da Embrapa Agroindústria de Alimentos.

\section{ROSANE FREITAS SCHWAN}

Prof. Titular na Universidade Federal de Lavras - UFLA, Bolsista CNPq 1B. PhD em Microbiologia pela University of Bath (UK). Foi pesquisadora na CEPLAC. Na UFLA, realiza pesquisas com fermentações de café, cana, cacau e mandioca. Atua como orientadora de mestrado e doutorado nos Programas de Pós-graduação em Microbiologia Agrícola e Ciências dos Alimentos - UFLA. 


\section{ROZILAINE APARECIDA PELEGRINE GOMES DE FARIA}

Possui graduação em Engenharia Sanitária pela Universidade Federal de Mato Grosso (1996), graduação em Química Licenciatura Plena pela Universidade Federal do Ceará (2001) mestrado em Química Orgânica pela Universidade Federal do Ceará (2003) e doutorado em Agricultura Tropical pela Universidade Federal de Mato Grosso (2009). Tem experiência na área de Química, com ênfase em Química dos Produtos Naturais, atuando principalmente nos seguintes temas: estudo de óleos voláteis, estudo de espécies de ocorrência do Cerrado para fins alimentares, aplicação de óleos essenciais e extrato de plantas em alimentos, compostos antioxidantes de interesse na área de alimentos.

\section{SABRINA LANGNER}

Graduação em andamento em Alimentos. Instituto Federal Farroupilha, IF-Farroupilha

\section{SELENE DAIHA BENEVIDES}

Engenheira de Alimentos e Mestre em Tecnologia de Alimentos, ambos pela Universidade Federal do Ceará - UFC e Doutora em Ciência e Tecnologia de Alimentos pela Universidade Federal de Viçosa - UFV em Viçosa, Minas Gerais. Pesquisadora A da Empresa Brasileira de Pesquisa Agropecuária - Embrapa. De 2006 a 2013 ficou lotada na Embrapa Caprinos e Ovinos, em Sobral, Ceará, atuando nas áreas de Ciência e Tecnologia de Alimentos; Tecnologia do leite e derivados caprinos e ovinos; Produtos lácteos caprinos probióticos e Produção Integrada da Caprinocultura Leiteira. Atualmente está lotada na Embrapa Agroindústria Tropical, em Fortaleza, Ceará, atuando com desenvolvimento de embalagens ativas, inteligentes e biodegradáveis para alimentos; encapsulamento de óleo de pequi e corantes extraídos de alimentos e, desenvolvimento de "queijo" à base de proteína vegetal.

\section{SILVIA MAGALHÃES COUTO GARCIA}

Professora Associada da Universidade Federal do Rio de Janeiro (INJC). Doutora em Ciências pela Universidade Federal do Rio de Janeiro com área de concentração em Segurança Alimentar (2008). Mestre em Ciência e Tecnologia de Alimentos pela Universidade Federal Rural do Rio de Janeiro (2002). Coordenadora do curso de graduação em Nutrição do INJC (2010 - 2014). Professora do Programa de Pós-graduação em Nutrição Clínica do Instituto de Nutrição/UFRJ. Atua na área de Nutrição e Ciências e Tecnologia de Alimentos com ênfase no seguintes temas: desenvolvimento de produtos funcionais, alimentos orgânicos, agricultura familiar, alimentação coletiva, gestão da qualidade e segurança alimentar e nutricional.

\section{SIMONE CURVO BETT}

Possui graduação em Nutrição pela Universidade Federal de Mato Grosso (1993). Mestre em Ciência e Tecnologia de Alimentos pelo IFMT (2014). É servidora público desde 1995 - Secretaria do Estado de Saúde de Mato Grosso. Tem experiência na área de Microbiologia, com ênfase em Microbiologia de Alimentos e Água.

\section{SUSANA BERLEZE DE PELEGRINI}

Trabalha desde 2015 até o momento como nutricionista na Unidade de Educação Infantil Ipê Amarelo na Universidade Federal de Santa Maria/RS. Graduada em Nutrição pela Universidade Franciscana (2008). Possui Pós-Graduação em Nutrição Clínica Funcional. Mestrado em Ciência e Tecnologia dos Alimentos pela Universidade Federal de Santa Maria (2013). 


\section{TIAGO SARTORELLI PRATO}

Mestre em Engenharia e Tecnologia de Alimentos (UNESP, 2010); Graduado em Engenharia de Alimentos (UNESP, 2006) e Personal, Profissional and Career Coaching (SBCoaching, 2018). Atua como Professor no Instituto Federal de São Paulo - IFSP Campus Barretos; e como Coach em alta performance, melhoria contínua e desenvolvimento de carreira.

\section{TIFFANY PROKOPP HAUTRIVE}

Nutricionista (Bacharelado - UFN e Licenciatura - UFSM), Mestra e Doutora em Ciência e Tecnologia de Alimentos (UFSM). Atualmente trabalha como Nutricionista que presta Assistência nutricional domiciliar. Atua como Nutricionista em consultório e presta serviço no Projeto Nutrir para a empresa Sintonia (SP). É professora convidada da UNOCHAPECÓ, do SENACRS- Santa Maria e UNIFEL (SP). Além disso, trabalha com Rotulagem de alimentos, Boas práticas de fabricação e planejamento de cardápios.

\section{ULISSES RODRIGUES DE ALENCAR}

Bacharel em Engenharia de Alimentos pela Universidade Federal de Goiás (UFG). Especialista em Processamento e Controle de Qualidade de Produtos de Origem Animal pela Universidade Federal de Lavras (UFLA) e tecnólogo em alimentos do Instituto Federal de Educação, Ciência e Tecnologia de Goiás (IFG).

\section{WELLINGTON OLIVEIRA}

Engenheiro de alimentos formado pela Universidade Federal do Ceará (2010). Doutor em Ciência de Alimentos pela Universidade Estadual de Campinas (2018). Tem experiência em Ciência e Tecnologia de Alimentos, com ênfase em Análise de alimentos e embalagens para alimentos, atuando principalmente nos seguintes temas: cromatografia, espectrometria de massas de baixa e alta resolução, interação embalagem/alimento, desenvolvimento e validação de métodos analíticos, técnicas de preparo de amostras e ensaios de migração.

\section{YZADORA MAURA DE FIGUEIREDO}

Graduanda na modalidade Bacharel em Economia Doméstica na UFRRJ e monitora da área de alimentação e nutrição - subárea: processamento. 


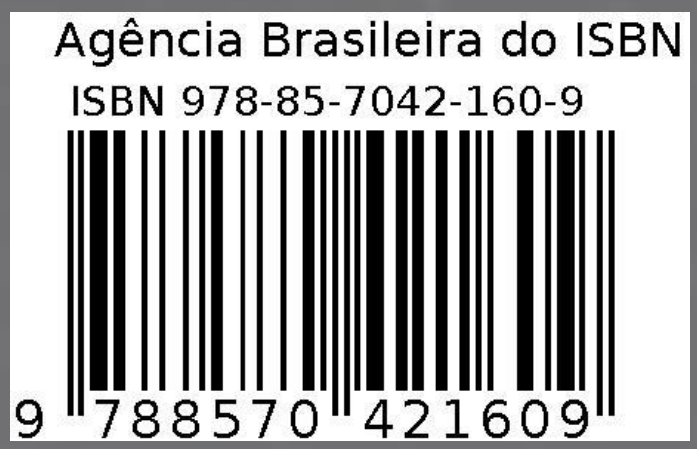

